edited by Georges L. Bastin \& Paul F. Bandia

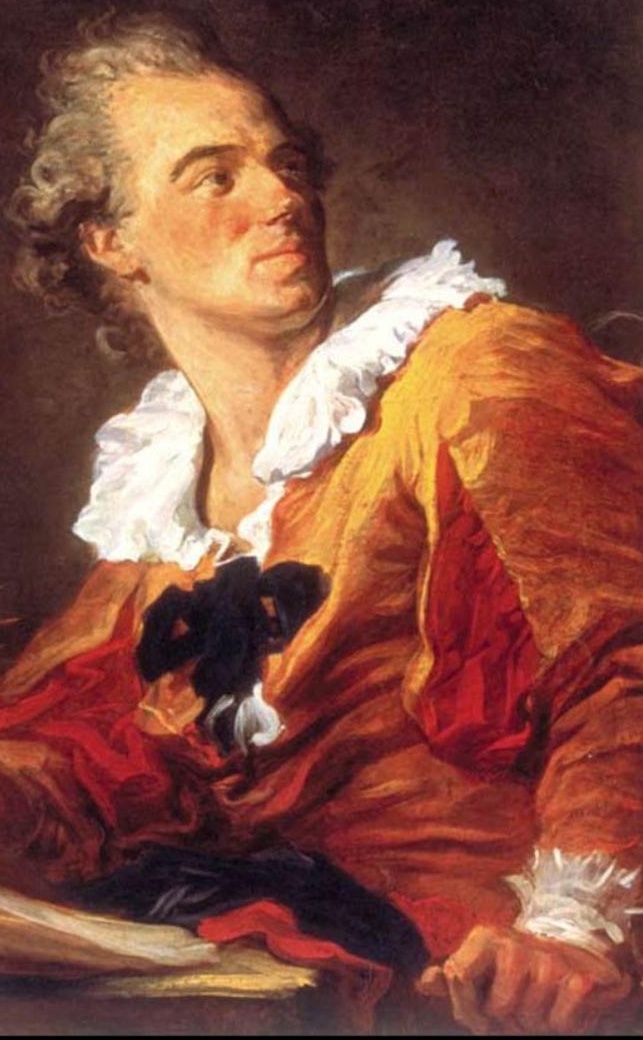

\title{
Charting the Future of Translation History
}




\section{Charting the Future of Translation History}


This page intentionally left blank 


\title{
Charting the Future of Translation History
}

\author{
Edited by \\ GEORGES L. BASTIN \\ and \\ PAUL F. BANDIA
}

III University of Ottawa Press 
The University of Ottawa Press gratefully acknowledges the support extended to its publishing programme by the Canada Council for the Arts and the University of Ottawa.

We also acknowledge with gratitude the support of the Government of Canada through its Book Publishing Industry Development Program for our publishing activities.

National Library of Canada Cataloguing in Publication

Charting the future of translation history / edited by Georges L. Bastin and Paul F. Bandia.

(Perspectives on translation, ISSN 1487-6396)

Includes bibliographical references and indexes.

ISBN-13: 978-0-7766-0624-8

ISBN-10: 0-7766-0624-7

1. Translating and interpreting-History. 2. Translating and interpreting-Methodology. I. Bastin, Georges L., 1952II. Bandia, Paul F. (Paul Fadio), 1961- III. Series.

P306.C49 2006 418'.0209 C2006-902718-8

All rights reserved. No parts of this publication may be reproduced or transmitted in any form or by any means, electronic or mechanical, including photocopy, recording, or any information storage and retrieval system, without permission in writing from the publisher.

Cover illustration: L'inspiration by John Honoré Fragonard (C) Corel Corpora

Copy-editing: Richard Thompson

Cover design: Sharon Katz

Interior design and typesetting: Laura Brady

Proofreading: Donna Williams

Published by the University of Ottawa Press, 2006

542 King Edward Avenue, Ottawa, Ontario K1N 6N5

press@uottawa.ca/www.uopress.uottawa.ca

Printed and bound in Canada 


\section{Contents}

ACKNOWLEDGEMENTS vii

INTRODUCTION

Methodology

SANTOYO, Julio-César Blank Spaces in the History of Translation 11

BANDIA, Paul F. The Impact of Postmodern Discourse on the History of Translation

MEYLAERTS, Reine Conceptualizing the Translator as a Historical Subject in Multilingual Environments: A Challenge for Descriptive Translation Studies?

ADAMO, Sergia Microhistory of Translation

BAIGORRI-JALÓN, Jesús Perspectives on the History of Interpretation: Research Proposals

BASTIN, Georges L. Subjectivity and Rigour in Translation History: The Latin American Case

FOZ, Clara Translation, History and the Translation Scholar 


\section{Current Discourses}

LAVIGNE, Claire-Hélène Literalness and Legal Translation:

Myth and False Premises

GADDIS ROSE, Marilyn The Role of Translation in History:

The Case of Malraux

BEN-ARI, Nitsa Puritan Translations in Israel:

Rewriting a History of Translation

GAGNON, Chantal Ideologies in the History of

Translation: A Case Study on

Canadian Political Speeches

ELDER, Jo-Anne Keepers of the Stories: The Role of the

Translator in Preserving Histories

ST. ANDRÉ, James "Long Time No See, Coolie": Passing as

Chinese through Translation

ARENCIBIA RODRIGUEZ, Lourdes The Imperial College of Santa

Cruz de Tlatelolco: The First

School of Translators and

Interpreters in Sixteenth-Century

Spanish America

FOSSA, Lydia Glosas croniquenses: A Synchronic

Bilingual (American Indigenous

Languages-Spanish) Set of Glossaries

YORK, Christine Translating the New World in Jean de Léry's Histoire d'un voyage fait en la terre du Brésil

ZARANDONA, Juan Miguel The Amadis of Gaul (1803) and The Chronicle of the Cid (1808) by Robert Southey: The Medieval History of Spain Translated

LIST OF CONTRIBUTORS 


\section{Acknowledgements}

\footnotetext{
The editors would like to acknowledge the financial support of the 1 Social Sciences and Humanities Research Council of Canada through a grant to the XVII ${ }^{\text {th }}$ Annual Conference of the Canadian Association for Translation Studies (CATS), from which the papers for this volume are drawn. They also acknowledge the financial and intellectual support of CATS and warmly thank Jean Delisle for his precious collaboration.
} 
This page intentionally left blank 


\section{Introduction}

L et's make History so as "to let our children benefit from a more brilliant tradition" motto for this book, and the attitude it expresses could be said to have motivated the contributors. This collection of studies is an attempt to point at blanks, at shortcomings which have prevented translation history from reaching its full disciplinary status among scientific fields and discovering the proper way to guarantee its own future.

Over the last thirty years there has been a substantial increase in activities relating to the history of translation. Both well-known and lesser-known specialists in translation studies have worked tirelessly to give the history of translation its rightful place. Numerous articles, theses, monographs, bibliographies, and anthologies have been published ${ }_{i}$ symposiums, conferences, and congresses have been organized ${ }_{i}$ journals and special collections have been launched. As a result, there exist today considerable resources of various types, based on differing approaches. Nevertheless, according to Lieven D'hulst (2001, 21), "the 
history of translation has not received the attention it merits in terms of research and cannot be compared to any other type of research in translation studies."

While most of the work has focussed on the "first" world (Europe and North America) and on its languages, new approaches inspired by disciplines such as postcolonial studies and gender studies, as well as research on a wide range of traditions such as those of India, China, Spain, or Ireland, have all contributed to broadening the field and making it more inclusive.

While much of the earlier work was descriptive, recounting events and historical facts, there has been a shift in recent years to research based on the interpretation of these events and facts, with the development of a methodology grounded in historiography. Translation in history is now being linked to themes such as otherness, ideology, manipulation, and power. Clearly, progress has been made, and the history of translation has become a viable independent research area within translation studies.

This book aims at claiming such autonomy for the field with a renewed vigour. It seeks mainly to explore issues related to methodology and a variety of discourses on history, and looks forward to laying the groundwork for new avenues, new models, new methods. It aspires to challenge existing theoretical and ideological frameworks. It looks toward THE FUTURE OF TRANSLATION HISTORY.

Answers are suggested for some questions raised, such as "Should history of translation draw much more on history and historiography?" and "Should the field develop its own methodology and research techniques?" From microhistory, archaeology, and periodization to subjectivity and postmodernism, methodological "blank spaces" are being filled.

Increasingly, translators and scholars are taken into consideration, scrutinized, and elevated as historical subjects. This trend could not be otherwise since texts definitely cannot exist without authors and readers; these continue to be the main raw material for letting history come to life. Contributors to this volume share this view, but in most cases 
they go far beyond the text to uncover the role translation has played in so many different times and settings.

The book is divided into two main blocks of readings which provide new insights into the two really significant trends that seem to be unfolding in translation history studies, namely discourses on methodology and discourses on history.

\section{Methodology}

In opening this section, Julio-César Santoyo makes a rough diagnosis of how translating activity, throughout its history of approximately four thousand, five hundred years, has been historicized. Though there are parts of that history that are well charted, there still remain "vast unknown territories" and large empty spaces yet to be filled in. There are also mistakes that Santoyo thinks it is imperative to amend, like the supposed existence of a Toledo "school" of translators. The "blanks" include, among others, the history of interpretation, the daily practice of translation, lost originals which only survive in translation, old theoretical and critical traditions of the East and Middle East, pseudo- and self-translations, and translations as agents of History. The author also pinpoints forgotten aspects of practical, everyday forms of translation that are not as well documented as those of a more "cultural" or "scientific" character. Arguing that translation "has made History," Santoyo shows us the immense task ahead and the commitment that will be necessary in the next generations.

Paul F. Bandia's article posits that for translation history to emerge as an autonomous discipline, translation historians should overcome the false perception of their status as mere archivists or translation scholars or practitioners "masquerading" as historians. To this end, the author highlights the relevance of the deconstructionist approach to history (against reconstructionism and constructionism) in accounting for the significance of postmodern discourse for translation history. This significance has been far-reaching, particularly in matters related to gender, minority, and postcolonialism, as well as questions of ethics in transla- 
tion theory and practice. These developments must be accounted for in translation history from a proactive, interventionist perspective.

To deal with the role of the translator as a historical subject in multilingual environments, Reine Meylaerts makes use of the idea of agency, looking particularly at field theory's habitus concept. Using a sociological approach, she intends to grasp the dynamics of literary translations from Flemish into French in interwar Belgium. Answers to the questions "Who has the right to be (or become) a translator?" and "Who has the obligation / mission to remain a translator?" require an analysis of the relations between structure and agency. Meylaerts observes that texts and discourses can cross so-called linguistic and cultural boundaries, disrupting the analytical pertinence of a clear-cut distinction between "sources" and "targets." Consequently, she argues the need for very flexible definitions of "sources" and "targets," definitions which need to integrate the concept of agency with communication-oriented models.

Sergia Adamo starts by questioning the role of historical awareness in translation history, mainly discussing D'hulst's (1991, 1993, 2001) concerns and proposals before offering some insights into microhistory. She recalls that the first commitment of microhistory is to recover the voice of marginal subjects on the grounds of fragmented and apparently minor data. Like Cronin (1996), Adamo regrets that the role of translators as creative and inventive mediators has been largely ignored in traditional reconstructions. Studying eighteenth-century translations of novels in a cultural area defined as Italian, she found that translations were an important factor in defining the female reading public. Especially at the stages of corpus definition (including not only textual and paratextual elements in the translations but also the translators' own statements contained in prefaces and dedications, as well as in their letters and memoirs or publishing data), materials collection, and problem focusing, she comes across many elements that fail to fit into any of the possible existing models.

Former UN interpreter and one of the very few researchers in history of interpretation, Jesús Baigorri-Jalón, begins his article by stressing the main obstacle facing those who embark upon the task of rebuilding the 
history of interpreting: the quest for sources and particularly secondary sources. He presents a table summarizing research proposals, divided according to possible topics for research, possible sources, methodological procedures, and difficulties the researcher might encounter. To take on the huge job still to be done, Baigorri recommends that researchers work in teams, constantly exchanging experiences and findings. He also advocates a rightful place for the history of translation and interpreting in training programs. We must be grateful to the author for his extensive bibliography, which shows that more has already been written in this field than we tend to think.

In his paper, Georges L. Bastin deals with subjectivity and rigour, referring in particular to the Latin American case. In his treatment of subjectivity, he examines the traditional Eurocentric vision that has dominated cultural studies in and on Latin America. He clearly denounces what he considers to be simplistic and even racist approaches. He then puts forward some local concepts (taken from cultural, literary, or philosophical studies) that better translate the complexity of the Latin American cultural reality. Some general orientations are given to help "localize" translation studies in the particular field of history in this part of the postcolonial world. Among other important factors, rigour is crucial in a field where firsthand sources are scarce. The author mentions several actual instances in which a seemingly minor lack of rigour made a big difference. He then encourages a necessary subjectivity expressed through a true local discourse and periodization.

Last but not least, Clara Foz examines the role of history in translation studies, focusing on two central issues within the field: the history of translation and periodization. First, she reviews the theoretical and methodological debates on the role of history, from claims of an objective historical truth to the so-called new history. Secondly, she stresses that periodization is fundamentally subjective and marked by its time and the institutions that produce it. She invites us to take advantage of the Historia a Debate website, which aims to stimulate discussion and reflection about history. She then turns to the "translation object" in 
history and studies periodizations by Ljudskanov, Steiner, Santoyo, and Ballard. The author concludes that practice opens the way to the object, not the other way around. This explains why the object of translation is now moving and changing under the influence of linguistic, cultural, or deconstructionist paradigms. This new vision offers a perspective that makes it possible to look at the translation object not as a given but as a construction.

\section{Current discourses}

The second section of the book is made up of papers that deal with a range of topics pertaining to different geographical locations and covering a wide expanse of historical time ranging from the Middle Ages to contemporary times. These discourses on history give us insight into past translation practices as well as the ideological, sociocultural, and historical circumstances that have determined translation choices and strategies in a variety of traditions over the centuries.

The section opens with Claire-Hélène Lavigne's paper on the history of legal translation, a remarkable effort given that the subject of history is rarely broached by legal translation scholars. Lavigne attempts to debunk the myth of literalness in legal translation practice, which has often been considered the inevitable consequence of the authoritative status of legal texts. Based on a thorough comparison of a translation of the Institutes done in thirteenth-century France and a fairly recent rendition, her paper argues convincingly that, like other forms of translation, legal translation practice is highly determined by factors such as the translator's objectives, the historical period when the translation is performed, and the legal culture of the target audience.

The next article, by Marilyn Gaddis Rose, is based on a reading of André Malraux's China novels in translation, as history rather than fictionalized reportage. The English translations of Malraux's Les conquérants and La condition bumaine, which are read as frequently as the originals, have expanded their author's readership and kept the historical record accessible. The translators of Malraux's novels, functioning as intermediaries, 
have at times endeavoured to transmit the author's acute perceptiveness, revealing the imperialist and colonialist subtexts, and exposing a postWorld War II pre-existentialist reading of heroism and altruism tainted by imperialist egotism and opportunism.

Nitsa Ben-Ari's paper is an insightful account of the role of moral censorship in the shaping of language and culture within the complex process of nation building. The author shows how puritan Zionist ideology led to the suppression of erotic material and the adoption of a puritanical approach to literature that dominated Israeli culture well into the 1970s and 1980s. Ben-Ari draws parallels between this Zionist ideology and Victorian Puritanism. The paper reveals the self-contradictory aspects of this form of censorship, which eventually undermined Zionism. It provides an alternative viewpoint regarding the development of literature and literary translation in Israel.

The role of ideology in translation is also explored in Chantal Gagnon's case study of political speeches and institutional discourse within the context of the classic conflict between the two founding nations of the Canadian federation. Gagnon shows how this conflict is played out in the ideologically-driven choices made in the translation of political speeches, resulting in translation shifts which often create conflicting images of the same event. She concludes that ideological translation shifts as practiced by the Canadian government are the result of deliberate institutional policies, which are determined by the value systems of Canadian society at various moments in contemporary history.

Jo-Anne Elder's article calls attention to the First Nations of Canada, so often overshadowed by conflicts between the French and the English. The article is fundamentally concerned with the preservation of the narratives of endangered cultures through translation, citing as an example Robert Bringhurst's work within the context of the history of aboriginal languages and literature in Canada. According to Elder, Bringhurst's work shows how translators can contribute to history by recording and translating texts written in an endangered language. Elder makes the argument that the works of literary translators (as 
practising artists) should be examined as literature and not simply as texts documenting cultural history.

Building on the concept of passing developed in African-American Studies and Queer Theory, James St. André discusses the practice whereby creative writing by some Westerners was passed off as genuinely Chinese at the dawn of the twentieth century. St. André focuses on the case of Ernest Bramah Smith, who could not read Chinese but sought to transcreate "Chineseness" in his English-language works. Smith modeled his transcreations after a style of writing developed through the translation of Chinese works into English. Through an analysis of the linguistic markers of "Chineseness" in English, St. André locates the origin of this practice in nineteenth-century sinological translation practice. He concludes by recommending further research into the history of sinological translation viewed in terms of passing.

The next paper takes us into the realm of the Americas as Lourdes Arencibia leads us to Mexico to visit the first major school of interpreters and translators in the New World, founded around 1533: the Imperial College of Santa Cruz de Tlatelolco. This college aimed at training native linguists with the capacity to perform a sort of spiritual crossbreeding, reconciling Renaissance humanism and Mesoamerican wisdom. Arencibia describes its location and origin, as well as the students and teachers (like Fray Bernardino de Sahagun), their work, the problems encountered, the teaching orientation, and so on. She emphasizes the permanent exchange of knowledge between natives and missionaries. Lost for centuries, the massive corpus of the translators and interpreters of the Imperial College of Santa Cruz de Tlatelolco has been recovered only recently.

In the same vein, Lydia Fossa presents the Glosas croniquenses project, which seeks to establish a synchronic bilingual glossary of terms from American indigenous languages and Spanish. Based on a distinct postcolonial approach as well as concepts such as heterogeneity and migration, this project offers a fresh view of research on early language conflict in the Americas. The project throws light on the dialectalization of Spanish in the Americas and enhances the linguistic resources of indigenous languages. It promises to be a major research resource for scholars and researchers from a variety of disciplines. 
Christine York's contribution also deals with the Americas as she explores the broader issue of translating historical texts and the importance of such translation for the afterlife of an original work. York discusses Janet Whatley's 1990 English translation of Jean de Léry's Histoire d'un voyage fait en la terre du Brésil, a classic account first published in 1578. In her study of Whatley's translation, York focuses on the naming of plants and animals of the New World, finding traces of indigenous voices within both the original and the translation, and highlighting the linguistic cross-fertilization that occurred in the contact between Europe and native America.

Finally, Juan Miguel Zarandona takes us through the history of travel writing and translation by British romantics fascinated by the Iberian Peninsula. In particular, Zarandona discusses Robert Southey's translations of Amadis of Gaul (1803) and The Chronicle of the Cid (1803). Both of these translations had to do with the medieval history of Spain, and they were undertaken mainly to satisfy the exotic interests of British romantics following their newly found enthusiasm for Spain and Portugal during the last decades of the eighteenth century.

These contributions, which deal variously with discourses on methodology and history, recast the discipline of translation history in a new light and pave the way to the future of research and teaching in the field.

GEORGES L. BASTIN

PAUL F. BANDIA

\section{References}

Briceño Iragorry, Mario. (1985). La bistoria como elemento creador de la cultura. Caracas: Biblioteca de la Academia Nacional de la Historia.

Cronin, Michael. (1996). Translating Ireland: Translation, Languages, Cultures. Cork: Cork University Press.

D'hulst, Lieven. (2001). "Why and How to Write Translation Histories?" In Emerging Views on Translation History in Brazil, ed. John Milton. CROP n ${ }^{\circ}$ 6, Sao Paulo: Humanitas / FFLCH / USP, 21-32. 
This page intentionally left blank 


\section{Blank Spaces in the History of Translation}

ver ninety years ago, on August 15, 1911, George Santayana, a well-known Harvard professor, philosopher, poet, and humanist, born in Madrid, gave a lecture at the University of California, Berkeley, on the topic The Genteel Tradition in American Pbilosopby. And these were his first words on that particular occasion, which I adopt, and adapt:

"Ladies and gentlemen," he began, "the privilege of addressing you today is very welcome to me, not merely for the honour of it, which is great, not for the pleasures of travel, which are many, when it is Winnipeg and the University of Manitoba ${ }^{1}$ that one is visiting, but also because there is something I have long wanted to say which this occasion seems particularly favourable for saying. ..."

That "something I have long wanted to say" deals here with the many "blank spaces" still found in the history of translation. And no wonder that such gaps and blanks may still be found, when our discipline (or subdiscipline) is but a young branch in the large tree of translation studies. I do not think, however, as Alexander Gross does, that "the field of translation history may be in its infancy." 2 Perhaps "in its adolescence," but definitely not in its infancy, because, as Bassnett and Lefevere wrote a few years ago $(1998,1)$, "History . . . is one of the things that happened 
to Translation Studies since the 1970s." I would even correct that statement, and say "since the mid-1960s," for it was in 1965 that Georges Mounin published in Italian his Teoria e Storia della Traduzione.

Since those forty pages by Mounin, and over the last thirty years, a long chain of titles of general scope have followed: After Babel by George Steiner (1975), The True Interpreter by Louis G. Kelly (1979), Interpretatio by Frederick M. Rener (1989), and then a good number of titles by Michel Ballard, Hans J. Vermeer, André Lefevere, and Susan Bassnett, Henri van Hoof, Jean Delisle, Judith Woodsworth, and Francisco Lafarga, among others; and before, after, and around them a countless number of nation-based, author-oriented monographs, conference proceedings, chapters of books, monographic issues of academic journals, and so on. It may be true, as Alex Gross claimed in 1996, that "no single book in this field can [yet] be considered a model of clarity and accessibility" ${ }_{i}{ }^{3}$ nevertheless, and again in Gross's words, "books like these are still of enormous value: they offer a rich harvest for those prepared to cut their way through their burgeoning undergrowth."

There is no doubt that since the mid-sixties, or even the seventies, a good distance has been covered, and we are now quite far from where we were in those days. Things have changed very quickly, at least from a doctrinal point of view. Already in the early 1980's Susan Bassnett stated in quite clear terms: "No introduction to Translation Studies could be complete without consideration of the discipline in an historical perspective" $(1980,39)$; and again, a few pages later: "The history of Translation should therefore be seen as an essential field of study for the contemporary theorist" $(1980,75)$. On the same lines, Antoine Berman $(1984,12):$ "The construction of a history of translation is the first task of a modern theory of translation." And he underlines the word modern.

However, when going over the long history of translation (or rather the miscellaneous and multifarious mosaic of partial historical studies, because a bistory as such is still to be written), the reader cannot help thinking he or she is being presented with a distorted image of the translation panorama throughout the centuries. And the only reason is, 
to be frank, that we are still far from having at our disposal a global and globalizing vision of what the translating activity has been throughout its approximately four thousand, five hundred years of history.

It is true that there are parts of that history that are well charted, the many translations of the Bible for instance. However, it is also true that there still remain "vast unknown territories" in that universal history, territories which concern not only places and times but also whole fields of inquiry and research. If we think of the history of translation as a mosaic, there can be little doubt that there are still many small pieces or tesserae missing, as well as large empty spaces yet to be filled in. The full design is far from complete. Much is still unknown.

I claim to uncover or reveal nothing new because, as professionals or amateurs of this discipline, I imagine that we are all also well aware of all those gaps along and across the coordinates of time and space. Let this paper therefore be nothing but a brief, cursory review of the several large uncultivated fields we can expect to plough in the near future.

\section{Oral translation or interpretation}

Almost everybody would agree that one of the most notorious empty spaces in our field is the history of oral translation or interpretation. There are so many books of national and international scope on the history of translation, and so few on the history of interpretation. Only in very recent years has attention begun to be paid to the activity of interpreters from a historical point of view, although limited in most cases to the twentieth century, with few and sparse references to their work before our times or in the centuries before America was discovered.

Most studies appear methodologically fragmentary and more like aggregations of "innumerable anecdotes found in secondary sources" 4 than true histories of a centuries-old profession. Such miscellaneous collections of data and anecdotes are extremely useful, certainly, but are still far from the idea of a true history. Let us consider such works as Ruth A. Roland's little-known Translating World Affairs (1982), which, revised and updated by Professor Jean Delisle, was reprinted five years 
ago under the new title of Interpreters as Diplomats: A Diplomatic History of the Role of Interpreters in World Politics (Ottawa: University of Ottawa Press, 1999). Similarly, we could mention Karttunen's Between Worlds: Interpreters, Guides, and Survivors (New Brunswick, NJ: Rutgers Univ. Press 1994).

However, the past is full of documents, both manuscript and printed. Take, for instance, the Anabasis. In the year 399 BC (the year in which Socrates was condemned), Xenophon led his troops, the "Ten Thousand," some 1,000 miles through the unknown and hostile territories of Kurdistan and Armenia; they reached the Greek city of Trabzon on the Black Sea early in 400 BC. The chronicle Xenophon wrote of that expedition, the Anabasis, brims with dozens of references to the mediation of professional and occasional interpreters from Greek into Persian, Armenian, Tracian, Carduchian, Macionese and Mossynaecian.

But the Anabasis is just one among thousands of examples. The diary of Antonio Pigafetta's circumnavigation in 1519-1522; the several voyages of James Cook; the accounts of English, French, Spanish, Dutch, and German explorers, travellers, and chroniclers in North, Central, and South America, the explorations of Africa and Asia, the work of missionaries throughout the world - all of these are full of notices about interpreters. According to Bede in his famous Ecclesiastical History of the English Church and People, Saint Augustine landed on the island of Thanet in 597, bringing with him several "interpreters of the nation of the Franks." ${ }^{5}$ An Arab boy from Jerusalem, serving as interpreter, helped Henry M. Stanley to finally discover Dr. Livingstone in the African village of Ujiji. And Bombay and Nasib traveled as interpreters of the party, led by John Hanning Speke, that discovered the sources of the Nile.

The chanceries of Europe are also full to overflowing with documents that tell of interpreters involved in embassies and legations (both secret and official), peace and trade treaties, settlements of frontiers, royal marriages. Another example deals with eighteenth-century ship's interpreters, a profession about which very little has been written, but which has existed (for at least five centuries) with its own statutes and 
regulations, including full details of their professional deontology and even what we would call today a "code of honour" (Santoyo 2003).

How much longer shall we wait for a general history of interpretation, not even of the world, but of a continent or a country?

\section{The daily practice of translation}

In the universal chronicle of translation the focus has always been on the book. And the more significant the original, the more studied any of its translations. There are thousands of pages on the translations of Shakespeare's poems and plays into this or that language, as there are thousands on the many translations of the book par excellence, the Bible, or the works of Marco Polo, Cervantes or Seneca, Ptolemy or Galen. These are no doubt the sort of translations which had the most influence on the development of culture and knowledge, at least in the West, and maybe they are the only ones worth recalling throughout the centuries. Remember the sentence of King Alfred, in the last years of the ninth century, when he admits in the prologue to his version of Cura Pastoralis, "It seems better to me . . . that we too should turn into the language that we all can understand certain books which are the most necessary for all men to know" (Swanton 1979, 31-32).

In point of fact, such translated texts are the only ones that count in any history of this art and craft, and it is quite evident that only minor references to other types of texts are found in the partial histories of translation published so far. Everyday, common, unerudite, unscholarly translations have hardly ever attracted the attention of historians. So exclusively have the spotlights been directed at the book that any other sorts of texts have been left in the shadow of history. ${ }^{6}$ However, books, whatever their nature, classical or modern, technical, historical, literary, philosophical, or religious, are but a part of the total landscape of translation, and from a quantitative point of view not even the most important part. During four hundred years, from the seventh to the tenth centuries, "as far as we know, only one Western book was actually translated into Arabic" [Orosius's Adversus paganos bistoriarum libri septem] (Lewis 
1982, 76, 141); still, the stream of translated documents between Christians and Muslims flowed uninterrupted, and many medieval chronicles brim with the names and performances of their translators.

Think, for instance, of the relations between Europe and the Mongols during the thirteenth century. Not a single book seems to have been translated between Mongolian and any European language, Latin included, during this century of Mongolian expansion, notwithstanding, the chronicles of the mutual relations abound with "acts of translation," messages, letters and documents which went to and fro in the hands of successive emissaries (William of Rubruc, friar Giovanni di Pian del Carpine, and friar Ascelino of Cremona among them), translated from Mongolian into Latin, from Latin into Russian, Persian, or Mongolian, from Greek into Mongolian, from Latin into Arabic or Syriac, and so forth.

Between the eighth and the fifteenth centuries, and much later on, translation covered spheres of interest and activity which clearly overflowed the narrow limits of the book: texts, most of them, of a pragmatic, matter-of-fact condition, which since the beginning of time have been present almost daily at school, at court, at church, in monasteries and chanceries, on routes of pilgrimage, at ports, harbours, and interstate frontiers. These practical, everyday forms of translation are not as well documented as those of a more "cultural" or "scientific" character, but even so they do not deserve the historiographical silence which has so far surrounded them.

In this respect, the only sources one can usually come across are slight (or worse, trivial) commentaries which hardly go beyond two or three lines, scarcely a whole paragraph. Such is the case, for instance, with Henri van Hoof's Petite bistoire de la traduction en Occident. A chapter containing a detailed account of the translational activity in France during the twelfth, thirteenth, and fourteenth centuries, centred above all on the translations of works by Gregory of Tours, Livy, Aristotle, Seneca and Cicero, Lucan, Virgil, and others like them, ends with this single sentence relative to "other" types of texts: "That translation has, moreover, played an administrative and diplomatic role, there can be no 
doubt" $^{\prime \prime}$ our translation ${ }^{7}$. And without any other explanation, the sentence is followed by a short anecdote about a certain letter which in 1447 was "translated from Saracenic into early French" (1986, 14; our translation). Full stop and new chapter.

However, the numerous medieval and Renaissance testimonies of the daily practice of translation all tend to confirm that in many countries it was a major factor of personal and official communication, present in everyday life at least since the end of the seventh century and throughout the Middle Ages. This circumstance has hardly ever been taken into account, however, dazzled as we are by the brighter lights of "the book."

No wonder, then, that in England at the beginning of the eighth century, Bede the Venerable translated from Latin several prayers and liturgical songs for the many illiterates who only knew their own language ["qui tantum propriae linguae notitiam habent"]; or that in the spring of the year 813 the Third Council of Tours decreed the translation of all sermons "in rusticam Romanam linguam aut thiotiscam," that is, into the vulgar French or German of the time.

Five centuries later, in the first decades of the fourteenth century, an amazing procedure was the normal, everyday way of doing things at the courts of the County of Kent, in the south of England (Clanchy 1979, 161):

First of all the jurors were presented with the justices' questions ... in writing in either Latin or French. They replied orally, probably in English, although their answers were written down as veredicta by an enrolling clerk in Latin. When the justices arrived in court, the chief clerk read out the enrolled presentments or veredicta in French, mentally translating them from Latin as he went along. On behalf of the jurors, their foreman or spokesman then presented the same answers at the bar in English. Once the presentments, in both French and English oral versions, were accepted by the court, they were recorded in the justices' plea rolls in Latin. 
A surprising exercise, no doubt, of linguistic and translational juggling, favoured by and derived from the situation of bilingualism and trilingualism in England at the beginning of that century. This was, by the way, very common throughout Europe of the Middle Ages, from Norman Sicily to Ireland and from the lands of Central Europe to the Iberian Peninsula, here with a variety of five languages plus Arabic and Hebrew.

Most of those translations were not intercultural but intracultural performances; there was no transference, no transmutation from a

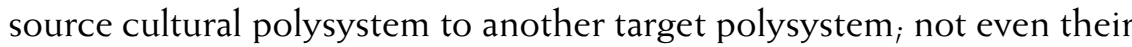
teleology had a cultural character: these translations were always made with a strictly local purpose and in order to make known strictly local contents. Quite far, therefore, from the translation of books, made to transcend "the moment and place of their production and reception" (Romano 1991-92, 222).

If translation is to be thought of not only as a translinguistic, but above all as a transcultural phenomenon, such a point of view must be left aside when approaching medieval, Renaissance, even modern everyday translations. If books were translated in medieval times "because of the wealth of knowledge they were thought to provide" (Chang 1994, 19), in everyday translations it is the direct, immediate, local, utilitarian necessity of understanding contents that inspires the act of translating. There is no express desire for cultural transcendence. "Est latine, non legitur": as it is in Latin, nobody understands it, and therefore it is translated. Such could be the ultimate reason for so many everyday translations.

This was to be the leitmotif (explicit) from the twelfth century onwards, as it had been (implicit) before. When in 1299 King Fernando IV of Spain confirmed the privileges of the town of Castrojeriz, he did it with a text translated from the original Latin into Castilian, "because the said privileges are in Latin, and the laymen cannot understand them" (Santoyo 1997, 169). When in 1378 Alfonso Pérez, a canon in the Spanish town of León, ordered a notary public to make a copy of four documents that were in Latin, he at the same time ordered their translation into Spanish, "because they were in Latin and therefore were obscure and difficult to understand" (ibid., 172-173). 
In such cases, it may be a surprise to many how the agents involved in the textual transfer express their will of exactness and radical fidelity to the letter of the document - quite far from the "liberty" one finds in other sorts of translations (literary, philosophical, scientific, and so forth). They had no interest in the form, nor in style: what really mattered to them was the identity of contents. In the translation of a document from San Miguel de Escalada (León) in the year 1380, the translator states that he has "turned the said Latin into vulgar Romance, everything word for word" [uerbo por uerbo] (ibid., 173). Two years earlier, when Alfonso Pérez, a Spanish canon, ordered the translation of several Latin documents into Spanish, three times he repeated that he wanted a translation "faithfully done," "faithfully translated from Latin into Romance," "faithfully translated and interpreted from Latin into Romance" (ibid., 172-173). This is a way of behaving far removed from what Lemarchard $(1995,30)$ believes to have been habitual among medieval translators of books. She says that "they felt perfectly authorized to modify a text in accordance with the audience it was meant for . . . ; a translator tackled his task feeling perfectly legitimized to graft any sort of comment onto the text, without even mentioning that he was deviating from the original text in order to add on something of his own invention."

Translation was an everyday component of medieval life, no doubt, and much more frequent and quotidian than what today's lack of studies may suggest. This is a very important aspect of translating activity (and of the history of translation) which it is absolutely necessary to recover, and the sooner the better if we want to have a complete picture of what translating signified for the daily life of medieval Europe. An aspect which, of course, should be approached from conceptual premises somewhat different from those of today.

\section{Pseudo-translations}

In spite of the cultural significance they have had throughout the last millenium, and in spite too of being "closely linked to genuine translation in terms of cultural position" (Toury 1995, 45), the field of 
pseudo-translations (or fictitious translations) is another empty chapter in our History.

In 1721 Charles-Louis de Secondat (1689-1755), Baron of Montesquieu, published his first literary work: one hundred and fifty letters under the title Lettres persanes, two small volumes apparently printed in Amsterdam. In the very prologue the "anonymous" translator had written: "Thus my role is limited to that of translator" [our translation]. Actually, as if in fact it were a translation, and in the best style of a belle infidèle, the "translator" added immediately afterwards:

I took all pains to make the work correspond to our morals. I relieved the reader of the Asian language as much as I was able and saved him from innumerable rarefied expressions, which would have bored him to heaven. . . . But that is not all I did for him. I cut back on the long compliments, which the Orientals proffer no less lavishly than us, and I passed over an infinite number of minute details. (Montesquieu 1949, 131-132; our translation)

Technically speaking, there was nothing new in the Lettres: as a collection of translated letters it had been preceded by, among others, the Lettres portugaises traduites en français, traditionally ascribed to Gabriel Joseph de Lavergne (1669), and above all by L'esploratore turco by Giovanni Paolo Marana (1684), which had already been translated into French with the title of L'Espion turc. This last work, for instance, is a collection of 531 letters supposedly written in Arabic by the Turk Mahmut and also supposedly translated into Italian by Marana.

From their very first edition the Lettres persanes met with an "immense and immediate" success ("immense et immédiat"), as Roger Caillois has defined it. After the first edition in Amsterdam, 1721, the Lettres were reedited over thirty times during the author's life (always in French) in Amsterdam, Cologne, Leipzig, London, and Paris. It was, no doubt, one of the French editorial successes of the century.

The most obvious and immediate consequence of that editorial fever was the long series of rewritings which throughout the eighteenth century were 
published in France as second parts, sequels, and imitations of the Lettres, all of them pseudo-translations written by foreigners of the most varied nations and cultures: Lettres d'une turque à Paris, Lettres d'une péruvienne, Lettres de Nédim Coggia, Lettres juives, Lettres cabalistiques, Lettres chinoises, Lettres siamoises, Lettres iroquoises, Lettres d'Osman, Lettres d'Amabed (by Voltaire), and so on.

At the same time, a second wave of rewritings had begun to take shape, this time under the form of translations: into English (Persian Letters, translated by John Ozell in 1722), into German (Persianische Briefe, 1759), into Russian (Piersidsieia Pisma, 1789), and so on.

As in France, the two English translations by Ozell (1722) and T. Floyd (1755) also were the direct (I would say the only) cause of the birth of a new literary genre in that literature: that of "letters written by foreigners." All were fake translations from this or that language, all rewritings, in one way or another, of Montesquieu's "Persian" letters. The list of titles is as long as that in France, even longer: Letters from a Moor at London, Athenian Letters, Sequel of the Letters Written by a Peruvian Princess, Letters from an Armenian in Ireland, A Letter from Xo-bo by Horace Walpole, Chinese Letters by Oliver Goldsmith, Letters of Clement XIV, Spanish Memoirs, Letters of a Hindoo Rajab by Elizabeth Hamilton, and so on. The complete eighteenth-century catalogue includes several dozen titles of major, middle, and minor literary value.

But Montesquieu's Lettres persanes are just one instance among the several hundred pseudo-translations with which the cultural and literary history of the West has been interspersed. Fictitious translations include such literary milestones as the Historia regum Britanniae by Geoffrey of Monmouth in the first half of the twelfth century ${ }_{i}$ Orlando innamorato by Boiardo in the fifteenth century; Don Quixote in 1605; Zadig by Voltaire; The Castle of Otranto by Horace Walpole in the eighteenth century; The Manuscript Found in Saragossa by Ian Potocki, and "Rappaccini's Daughter" by Nathaniel Hawthorne in the nineteenth; and in the twentieth century, The Immortal and Doctor Brodie's Report by Borges, The Council of Egypt by Leonardo Sciascia, Mrs. Caldwell Speaks to ber Son by the Nobel Prize laureate Camilo José Cela, and The Duchess's Diary by Robin Chapman. 
Sometimes received by the reading public of their time not as originals but as true translations (as was the case of The Castle of Otranto by Horace Walpole in England and of Papa Hamlet by Arno Holz and Johannes Schlaf in Germany), pseudo-translations occupy a very special place in the history of literature. But it should not be forgotten that they also belong, in more ways than one, to the history of translation.

It may be worth recalling here Toury's words on the subject (1995, 41): "Pseudotranslating has not always been so marginal as it may now seem to be. ... At the same time, pseudo-translations are far from a mere curiosity, which is how they have been treated all too often in the literature. In fact, they often prove highly revealing for cultural studies, especially in their historical facet, including culture-oriented Translation Studies."

By the way, it is quite surprising, and paradoxical too, that on the one hand, all throughout the centuries, "translators have been widely scorned at times and their work severely criticized"; they "have been distrusted, and even called turncoats and traitors" (Joly 1995, xiii); whereas, on the other hand, their work, their translations, have given rise to a narrative technique used by writers of no lesser stature than Voltaire, Cervantes, Montesquieu, Walpole, Goldsmith, Borges, Cela, and Hawthorne, among many others.

\section{Self-translations}

Another vast territory without history is self-translation, defined thirty years ago by Anton Popovič as "the translation of an original work into another language by the author himself" $(1976,19)$. It is surprising how mistaken commonplaces can go on and on for decades. Self-translation, I have no doubt, is an area of translation studies that so far has been almost forgotten, perhaps because we all think that it is and always has been something absolutely marginal, a sort of cultural or literary oddity. Several testimonies, chosen at random among many others, may bear witness to a widespread opinion.

Antoine Berman, in the first pages of his essay L'Épreuve de l'étranger: 
"For us, self-translations are exceptions" (1984). Grady Miller, in a paper read at the American Translators Association Annual Conference: "Historically, few authors have dared to translate their own works" $(1999,11)$. Professor Christian Balliu in a paper published three years ago in META, the Canadian quarterly: "It must be admitted that examples of self-translation . . . are extremely rare in literature and form the exception" (2001, 99; our translation). Four years ago John Benjamins published a volume, edited by Allison Beeby et al., under the title Investigating Translation. In one of the contributions, by Helena Tanqueiro, the reader is informed that "[throughout history] only a few [writers], very few indeed, actually translated their own work" (2000, 50). In his introduction to The English Writings of Rabindranath Tagore, Sisir Kumar Das, Professor of Bengali and Comparative Literature at the University of Delhi and Vice-president of the Comparative Literature Association of India, states in a fairly definite way: "Undoubtedly he [Tagore] is the only major writer in the literary history of any country who decided to translate his own works to reach a larger audience" $(1994,10)$. It is worth repeating (and remembering) his words: Tagore is the only major writer in the literary history of any country who decided to translate his own works.

Exceptions, few, very few authors, rare enough, rarissimes. Even György C. Kálmán, of the Institute for Literary Studies of the Hungarian Academy of Sciences, rashly described self-translation in 1993 as "a borderline case" of both translation and translation studies. That seems to be today "the state of the art." And when so many people, so well qualified, and all through the last forty years agree on such a description and definition, no doubt again, they all must be right. Self-translation lacks any place in history; small wonder, then, that Professor Brian T. Fitch, University of Toronto, could write sixteen years ago in his book Beckett and Babel: "Direct discussion or even mention of self-translation is virtually non-existent in writings on theory of translation" $(1988,21)$. Small wonder, again, that only six years ago Shuttleworth and Cowie could also write in their Dictionary of Translation Studies: "Little work has been done on autotranslation" $(1997,13)$. 
Against the grain of all these judgements and opinions, the sheer truth is that self-translation has been present in the history of this art and craft at least since the times of the Jewish historian Flavius Josephus in the first century of our Common Era. He wrote his first work, the seven books of The Jewish War, in his mother tongue, Aramaic, for the benefit of the Jewish communities in the Diaspora. Some years later he himself reviewed and translated it into Greek, correcting at the same time some of the errors he had before run into. In the preface to his Greek version he clearly states: "I have proposed to myself, for the sake of such as live under the government of the Romans, to translate those books into the Greek tongue which I formerly composed in the language of our country. ..." 8

Two thousand years of self-translations after Flavius Josephus are still waiting for inclusion in the pages of our History. Hundreds, perhaps thousands of texts have been written in one language and then transferred by their authors into a second tongue: in medieval Spain, in Renaissance Italy, in seventeenth-century England (think of John Donne), or in present day Belgium, Turkey, Canada, or Brazil.

Self-translators have included the medieval philosopher Raimundus Lullius, the humanist Leonardo Bruni, Thomas More, Étienne Dolet, Du Bellay, Jean Bodin, John Calvin, Pietro Bembo, the poet Andrew Marvell, the philosopher Spinoza, the Italian playwright Carlo Goldoni, the French poet Mallarmé, James Joyce, and the Nobel Prize recipients Mistral, Tagore, Pirandello, Beckett, Singer, Brodsky, and Milosz. Plus Julien Green, Romain Gary, and Elsa Triolet in France, Karen Blixen in Denmark, Aitmatov in Russia; and in our own days Raymond Federman, Nancy Huston, and an endless list of authors, particularly within the world of literature.

In Spain, over two hundred writers are nowadays translating their works from Catalan, Basque, or Galician into Castilian, even into French. In India, dozens of writers are also nowadays transferring their works from Urdu, Bengali, Hindi, Gujarati, Malayalam, or Tegulu, mainly into English. And the same phenomenon is taking place in South Africa, Puerto Rico, India, Ireland, the United States, and elsewhere. 
In Canada you may well know the case of Honoré Beaugrand (1848-1906), journalist, traveller, and also mayor of Montreal, who wrote "La chasse-galerie" in French and then translated it into English, publishing it in 1891 in French in the journal La Patrie and the next year in English in The Century Illustrated Montbly Magazine. He also translated another of his stories, "Macloune" (vide Grutman 1994), from French into English.

Being, on the one hand a bilingual country and on the other both a land of asylum for many exiles and a nation where foreign authors thrive in academic circles, it is small wonder that Canada is home to an extensive list of authors who are now self-translating their originals into a second language: Nancy Huston, Patrice Desbiens, Guy Arsenault, Melvin Gallant, Moin Ashraf, Alfredo Tutino, Claude Hamelin, Jean Grondin, Nicole Brossard, Chava (or Chawa) Rosenfarb, Guy Maheux, and Daniel Gagnon, among others.

Self-translations are not at all exceptions, nor are they rare enough, nor few, very few indeed; we cannot keep saying that they are "not very common in the field of creative writing," or that "few authors bave dared to translate their own works," or that they are borderline cases. Research in the history of this particular area will show, is in fact beginning to show, that as Christopher Whyte wrote two years ago, "self-translation is a much more widespread phenomenon than one might think" $(2002,64)$. And worthy, therefore, of receiving much more attention than it has so far received.

\section{Forgotten texts}

Another field awaiting the work of historians is the rescue and recovery of many forgotten texts. Nowhere have I seen mentioned, for instance, one of the very first reflections of a translator on his own work, to be found in the prologue of Ecclesiasticus, one of the books of the Bible that is non-canonical for Jews and Protestants but canonical for Roman Catholics. Written in Hebrew at the beginning of the second century BCE, Ecclesiasticus, or the book of Sirach, was translated into Greek around the year 132 BCE by the anonymous grandson of the author. In the prologue to his translation he writes (mind the year, $132 \mathrm{BCE}$ ): 
You therefore are now invited to read it [this book] in a spirit of attentive good will, with indulgence for any apparent failure on our part, despite earnest efforts, in the interpretation of particular passages, for the words spoken originally in Hebrew are not as effective when they are translated into another language. That is true not only of this book but of the Law itself, the prophets, and the rest of the books [of the Bible], which differ no little when they are read in the original. ...

And in a new paragraph:

I therefore considered myself in duty bound to devote some diligence and industry to the translation of this book. Many sleepless hours of close application have I devoted in the interval to finishing the book for publication, for the benefit of those living abroad who wish to acquire wisdom and are disposed to live their lives according to the standards of the Law. ${ }^{9}$

Everybody quotes Cicero's famous sentence, so often repeated: "In quibus non verbum pro verbo necesse habui reddere." Very few (if any) remember that, over a hundred years before Cicero, it was Terence who first used the expression "verbum de verbo" (word for word) when speaking of his translation of Menander's The Brothers [Adelpbi], a comedy played in Rome in the year 160 BCE: ". . . eum hic locum sumpsit sibi in Adelphos, verbum de verbo expressum extulit."

We badly need to recover, for instance, the entire tradition in Arabic, which spans from the eighth century to our own days, and which when cited, if cited at all, is often dismissed in less than one page. A quick review of several translation theory anthologies, from Paul A. Horguelin to Douglas Robinson, makes quite clear the absence of non-European thinkers and writers, either Arabs or Chinese, Indians or simply Latin Americans.

We in the West are quite unfamiliar, for instance, with many of the dicta in the Arab tradition of translational thought and criticism, among 
them the opinions of Hunayn ibn Ishaq, the great ninth-century expert in translation from Greek into Syriac and Arabic. We are also quite unacquainted with the opinions of another contemporary of his, Abû Utmân al-Jâhiz (830 approximately), and with his surprising and pioneering statements on the difficulty, even impossibility, of translating poetry (al-Jâhiz 1938, 75-79):

If translated, the very essence of poetry is destroyed. Poetry is only enjoyed by the people to whom it belongs. As a literary manifestation, it is untransferable; it never is universal, because it is always tied up to, and trapped by the language in which it was written. . . . Poetry cannot be translated, should not be translated, because, when translated, its music, rhythm and poetic structure disappear, its whole beauty fades away, and nothing really worth admiring is left $t_{i}$ in point of fact, translated poetry ends up by becoming plain prose. ...

And again, with regard to the "musts" of a translator:

A translator must measure up to the subject matter he is translating, must have the same knowledge as the author he is translating. He must be well versed in the language he translates, as much as in the language into which he translates, so that he be equal in both. . . The more difficult a discipline and the fewer experts in it, the more important are the difficulties a translator finds, and the more exposed he is to making mistakes. ...

All this, and much more, in the year 830 .

At the dawn of the tenth century, Ahmad ibn Yûsuf wrote in his Epistle on Proportion and Proportionality: "In addition to having reached a more than remarkable knowledge of the languages from which and into which he translates, it is also necessary that the translator have a very good grasp of the subject matter he is translating" (Gil 1985, 44).

Mention can also be made of Abû Alî ibn al-Samh, at the end of the 
tenth century, and the extreme care with which he collated several translations of the same text. Or the name and opinions of the translator of Aristotle, al-Hasan ibn Suwâr al-Hammar, around the year 1000: "In order to reproduce the meaning, the translator needs to understand it by means of the language from which he is translating, so that he perceives it as fully as the original author expressed it ${ }_{i}$ he must know the use of the source language, as well as that of the language into which he is translating" (Hugonnard-Roche 2001, 27). Or, just as a last example, the name and opinions of Salâh al-Dîn al-Safadî, halfway through the fourteenth century, with details of the two methods used by translators in his own time (Badawi 1968, 33):

There are translators who examine every single Greek word and its meaning, select then an equivalent word in Arabic, and just write it down; then they pass on to the next word, and so they proceed along till the translation is finished. But this is a wrong method, and that for two main reasons: first, because in Arabic there are no equivalents for every Greek word, and as a consequence we see that many Greek terms are left untranslated, secondly, because the syntax and sentence structure in one language does not always correspond to that of another language. . . The second method of translating is much better: it consists in reading and fully understanding the sentence, and then translating it by means of an equivalent sentence; it does not matter whether or not the words themselves are of the same value. . .

\section{Translated texts as survivors of lost originals}

In spite of their cultural significance, no history of translation has taken into consideration the role of translated texts as survivors of lost originals. In a recent paper Joâo Ferreira Duarte asked $(2003,16)$ : "Do they [translations] have a function in history other than being the afterlife of the original, as Walter Benjamin put it?" Of course they have, particularly in 
the case of lost originals, which have come down to us only in translation: they now function in history as true originals, because the text from which they derived has disappeared, and the translated text has assumed the function of the original. However, that function, as far as I know, has hardly been chronicled, studied, or estimated.

It is not a case of one or two isolated instances. We know many ancient, medieval, and even Renaissance writings thanks to their translations, the originals having been lost for good and all. This is true in the case of a large portion of paleochristian literature, which only survives in translation and includes nothing less than the Gospel according to Matthew, which we now have in Greek. Both Papias and Jerome firmly believed, and insistently repeated, that Matthew had written his Gospel "in the Hebrew language" (Rajak 1984, 232) [Hebraeis litteris uerbisque]. In his Commentary on Matthew, Origen wrote: "I have learned by tradition that the Gospel according to Matthew . . . was written first, and that he composed it in the Hebrew tongue and published it for the converts from Judaism. . .." And again, Jerome in his De viris illustribus: "Matthew ... first composed the Gospel of Christ in Judaea, in Hebrew letters and words [Hebraeis litteris uerbisque] . . ; but we do not know for sure who later translated it into Greek. . . . This Gospel in Hebrew is still held today in the library of Caesarea [Maritima], which the martyr Pamphilus carefully put together. I also was able to make a copy from the Nazarenes, who use this volume in Bresoa, a city of Syria. ..."

Many of the Greek works of Evagrius Ponticus (such as the Commentaries on the Cherubim and Serapbim) are only extant in Syriac and Armenian translations. The same could be said of Eusebius of Caesarea's Cbronici Canones, which but for a few fragments survive in an Armenian version and in Jerome's Latin translation. And the same again is true of the greater part of Origen's Peri Arxon (On the principles), of which only a translated text made by Rufinus in the year 398 has come down to us. The Apology for Origen which the martyr Pamphylus wrote in Greek has also disappeared, and only its first book survives in Rufinus's Latin translation.

The apocryphal account of St. Paul's voyage, so popular in medieval 
times, was originally written in Greek, but we only have its Latin version, known as the Visio Pauli (Blake 1972, 30).

In the year 1264, Bonaventura da Siena, notary of King Alfonso the Wise, translated from Spanish into French and into Latin the Mira'j or Book of the Scale of Mubammad, which had previously been translated from Arabic into Castilian by Abraham of Toledo. Both the original in Arabic and the text in Spanish have disappeared, and only their two translations, into Latin and French, have survived (Liure de Leschiele Mabomet).

Throughout the thirteenth century and the first decades of the fourteenth, Raimundus Lullius wrote many of his treatises in Arabic, in Latin, or in Catalan. Though some of his first originals are now lost, they are preserved in his own translations, such as the book On the Contemplation of God, which Lullius wrote in Arabic but which remains only in Catalan and in Latin.

Let us skip over the fourteenth and fifteenth centuries, because there are too many cases of lost originals preserved only in translation to be mentioned here, and limit ourselves to a well-known example of the seventeenth century.

In 1660 the Dutch philosopher Benedict (Baruch) Spinoza wrote in Latin his Short Treatise on God, Man, and His Well-Being. A few months later, at the request of some friends "whose Latin was less than fluent" (Nadler 1999, 186), he translated his text into Dutch. "Although originally written in Latin, like all of Spinoza's other writings, the work has only come down to us in a Dutch translation, and it was not published or generally known until its discovery in the nineteenth century" (Allison 1975, 23).

\section{Mistakes}

Gaps, holes, blank spaces, ... and mistakes, too, which must absolutely be amended - little pieces in the mosaic which definitely do not belong to it. In fact, one of the most important tasks of today's historians is to denounce, correct, and eradicate the serious mistakes that have slipped into a good number of present-day texts. Let us stop to consider two of these errors because, besides serving as examples, they concern 
basic points of the history of translation in Europe, and particularly in the Iberian Peninsula.

Example number one: It is high time that we stop speaking of the socalled Toledo School of Translators. Never was there such a school in Toledo, neither in the twelfth century with Bishop Raymond nor in the thirteenth century with King Alfonso X the Wise. However, this school has proved to be one of the most lasting myths in the history of contemporary culture, present everywhere, from the Encyclopaedia Britannica to thousands of pages on the Internet.

It was Amable Jourdain who in 1819 first made the mistake of speaking of a "collège de traducteurs" in that Spanish town, when in fact the translators he ascribed to the "Toledo School" carried out their tasks in many other parts of the country, places sometimes quite far from Toledo. The error, however, soon spread all over Europe, and after Jourdain many other nineteenth-century scholars used to refer to the same "school." One of them was Valentin Rose, who in 1874, in his article "Ptolomaeus und die Schule von Toledo," spoke of "eine förmliche Schule arabisch-lateinischer Buch- und Wissenschaftsübertragung" (Hermes, 8:3, 327-349, 327).

$\mathrm{No}$, there was no such School of Translators at Toledo, if "school" is to be understood in any of the normal senses of the word. Already in 1942 Angel González Palencia $(1942,118)$ had to admit that "the very few documents which so far have been found do not provide a basis to assert the existence of such a centre of translations." Half a century later, in 1998, Clara Foz published in Ottawa a book under the title Le traducteur, l'Église et le roi (soon translated into Spanish: El traductor, la Iglesia y el rey, Barcelona: Gedisa 2000), dealing precisely with translation in the Iberian Peninsula during the twelfth and thirteenth centuries. Her assertions leave no place for further speculation. She writes (1998, 105-107):

An examination of the data with regard to translators of that era and their travels shows that in fact, Toledo was only one of the places certain twelfth-century men of letters went to. . . Nothing suggests, however, that a space devoted to translation activities 
existed in the Castilian capital and that the work was directed. . . The precise framework under which their work was carried out remains open to conjecture. . . Indeed, no specific description of the exact places where these activities took place exists. [our translation]

Four years ago Anthony Pym published the volume Negotiating the Frontier: Translators and Intercultures in Hispanic History, whose first four chapters deal precisely with this "school." Three quotations gleaned from Pym's book (2000, 34, 35, 56): 1. "The references to Toledo are not strict in any geographical sense, since twelfth-century translations from Arabic were carried out in many parts of Hispania, often in the north"; 2 . "No medieval author would seem to have referred to Toledo as a 'school,' much less as a school of translators"; 3. "The notion of a 'School of Toledo' (in very capital-letter senses) has been mythologized in such a way as to make its historical coverage as broad as possible."

More or less the same can be said of the famous ninth-century Baghdad "school of translators." Myriam Salama-Carr (1990, 31; Pym 2000,36) defines it as merely "a team or group of translators." And then there is Dimitri Gutas, Yale University $(1998,59)$, on the Baghdad "House of Wisdom" (bayt al-bikma) "school":

It was certainly not a centre for the translation of Greek works into Arabic $_{i}$ the Graeco-Arabic translation movement was completely unrelated to any of the activities of the bayt al-bikma. Among the dozens of reports about the translation of Greek works into Arabic that we have, there is not even a single one that mentions the bayt albikma... The first-hand report about the translation movement by the great Hunayn himself does not mention it. . . .

Crystal clear, or as clear as daylight. The myth of the "Toledo School of Translators," however, has been so often repeated that it seems almost impossible to eradicate it. Few lines contain a larger accumulation of 
inaccuracies than the following short paragraph by Henri van Hoof in his Petite bistoire de la traduction en Occident:

Starting in 1135, Archbishop Raymond of Toledo ... founded a School of Translators, which was literally a school where courses were given and where, for more than a century and a half, Italians, Frenchmen, Englishmen, Jews, and Flemings earned renown, alongside Spaniards, in a vast translation undertaking sponsored by the Church (van Hoof 1986, 10, our translation).

There was no foundation, and consequently nothing was founded, by any archbishop; there was no collège, no véritable école, no courses whatsoever, nor, finally, was it the Church that, for over a century and a balf, sponsored the work of those translators.

This last remark could be true of the first period, in the twelfth century, but it is rather difficult to think in such terms of the second period, in the thirteenth century, unless van Hoof considers King Alfonso the Wise to have been a member of the ecclesiastical hierarchy.

This has been an ill-fated appellation, inherited from an initial collège, translated into German as Scbule, Übersetzerscbule, and then into English as School of Translators, Scuola di Traduttori in Italian (Mounin 1965), Escuela de Traductores in Spanish, and so forth.

Another quotation from Henri van Hoof's Petite bistoire: "The French monk Peter the Venerable . . translated the Koran in 1139. . . Robert of Chester provided a new translation of the Koran in 1141-43, with Hermann of Carinthia" (van Hoof 1986, 10-11; our translation).

Commentary and correction: Pierre de Montboissier, known as Peter the Venerable, Abbot of Cluny, never translated the Koran, neither in that year nor on any other date. Yes, he entrusted Robert and Hermann with the task, and this was the first time it was translated into any European language. But neither Robert nor Hermann could make a new translation, because the one by Peter the Venerable belongs to the realm of imagination.

Van Hoof again (ibid.): 
It was not until around 1200 that copies of Greek originals began to arrive in Toledo and that people began to recognize the value of making direct translations of them, without passing through a third language. From that moment on, the School of Translators translated . . . from Greek to Latin.

Commentary and correction: there is no evidence whatsoever that around the year 1200 Greek originals began arriving in Toledo, nor that direct translations from Greek into Latin were being made there.

Example number two: Four years ago J. F. Ruiz Casanova published in Spain (Madrid: Cátedra, 2000) a thick volume, over five hundred pages, entitled Aproximación a una bistoria de la traducción en España (Approximation to a History of Translation in Spain). Three short quotations from the very first pages: 1 . "If we limit ourselves to the Iberian Peninsula . . . , we know that .... in the fourth century bishop Ulfilas translated from Greek into Gothic all the Bible except the Books of Kings" (23-24); 2. "However, this Gothic Bible was not the first sample of translation in the Iberian Peninsula after the fall of the Roman Empire" (46); 3. "Apart from the translations made in the Iberian Peninsula from the 4 th to the 6th centuries, done by Ulfilas, St. Martin and St. Pascasius . . ." (54).

The three quotations repeat the same idea: in the Iberian Peninsula, Ulfilas translated from Greek to Gothic all the Bible, except the overly warlike Books of Kings. I imagine that many a Germanist has already gone through the roof: Ulfilas never was in the Iberian Peninsula, not even near it, and, consequently, he couldn't in any way have made his famous translation there. He was the Arian bishop of Lower Moesia, not far from today's town of Trnovo, in Bulgaria, and it was there, and in Constantinople, that he spent forty years translating the Bible. Exactly the same mistake has been repeated by Alberto Ballestero in his Diccionario de Traducción: "Translation in Spain starts officially at the beginning of the twelfth century ...., although already in the fourth century bishop Ulfilas, who, besides Gothic also knew Greek and Latin, had translated the Bible into Gothic" (Ballestero 1998, 19; our translation).

Errors like these are quite common in many pages of history, and, 
what is worse, in some histories of translation. As historians, it is our duty to remove, erase and rub them out completely.

\section{The role played by translation in History}

Not only is translation the object of historical study, but it has also played a leading role in History (this time with a capital letter). Translation itself has made History, a particular which has seldom been taken into account. Think, for instance, of what has become known as the anti-Spanish Black Legend, something still alive and kicking in many pages of History, which keep on ascribing the beginning and success of the legend to a work by the Dominican friar Bartolomé de las Casas, the Short Account of the Destruction of the Indies (Brenissima relacion de la destruycion de las Yndias). However, this general opinion needs to be carefully nuanced. The Short Account was first published in Seville in 1552. A year passed, and ten, and twenty ..., and dust piled up on the shelves on which the Short Account was lying, forgotten by everybody, without even a second edition for as long as twenty-five years.

But in those twenty-five years many things had happened in Europe. The Low Countries were now up in arms against the Spanish government, England and France were also sworn enemies, and as in any war, propaganda became a powerful weapon. And the forgotten Short Account was a perfect propaganda tool against Spain, first because it was written by a Spaniard, and on top of that a man of religion. Secondly, because spreading abroad its contents, laying it on thick, helped display the intolerance and perversity of the Spaniards throughout their territories.

In only five years, 1578 to 1583 , the Account was translated into Dutch, French, and English, with five different editions in Antwerp, Paris, and London. This was followed year after year, insistently, throughout a whole century, by no fewer than thirty new editions and translations into French, Dutch, German, Latin, and Italian. Obviously, translating in that sociopolitical atmosphere was equal to manipulating very consciously — manipulating everything, from the 
very title to the colophon. Little wonder, then, that the first translation of the Short Account into French in 1579 bears the title of Tyrannies et cruautés des espagnols, perpétrées aux Indes Occidentales; or that the 1656 English edition appears under the title of The Tears of the Indians: Being an Historical and True Account of the Cruel Massacres and Slaugbters of above Twenty Millions of Innocent People.

However, it was the Latin edition published in Frankfurt in 1598 (Narratio regionvm Indicarvm per Hispanos qvosdam deuastatarum verissima) which caused a major impact on the public. Indeed, in a way, it became "canonical," particularly because of the sensational engravings of tortures illustrating a text which, manipulated over and over again to unimaginable extremes, was by now quite far removed from the original. Friar Bartolomé, for instance, had written (Pereña 1989, 216; our translation):

The care they took of them was to send the men to the mines to dig out for gold, which is an unbearable kind of work; and the women were sent to farms, in order to dig up the earth and cultivate the fields, which is a job for very strong and sturdy men.

This same paragraph, at the foot of a horrifying engraving of tortures, became in the Frankfurt edition as follows (ibid.):

Those who worked in the mines, or elsewhere, and who were not diligent enough, were also treated in a most pitiful way; for not only were they tied up to poles, but they were also flogged with whips soaked in pitch, so that they were left as dead. And what is even worse, after having flogged them in such a cruel manner... the Spaniards also dropped burning grease on their wounds.

The origin of the Black Legend, therefore, does not lie in the Short Account, which per se did little to create it, as was more than evident in those first twenty-five years after its publication, 1552 to 1577 . The true origin must be looked for in the manipulated translations which 
uninterruptedly fuelled anti-Hispanic prejudices starting from 1578, translations into Dutch, French, German, English, Latin, and Italian. They were the true and only vehicle of diffusion of this legend all over Europe, at the service of very specific political and religious interests. They mark, as Eric Griffin has recently written, "a pivotal moment in one of the most successful propaganda campaigns ever carried out: as the Brevissima relacion is translated, printed, and reprinted in contexts far removed from that of its initial publication, the acts it recorded gave rise to the Hispanophobic typology." 10

This is just one example, but it could easily be multiplied ad infinitum because more or less the same could be said, in those same years, and along the same lines, of the Apology of William of Orange against Philip II, translated in scarcely twelve months (1581-82) into French, German and Latin; and the same could be said, again, of the Sanctae Inquisitionis Hispanicae artes aliquot detectae, published in Latin in Heidelberg in 1567 and immediately translated into English, French, and Dutch. The English edition, appearing in 1568, bore the title of A Discovery and Playne Declaration of Sundry Subtill Practises of the Holy Inquisition of Spayne.

In our own days, a wrong translation might have been the ultimate reason for the dropping of the first two atomic bombs. On July 28, 1945, two days after the Potsdam Declaration, the Japanese Prime Minister Kantaro Suzuki declared at a press conference that the Potsdam Declaration was "a thing of no great value," and added: "We will simply mokusatsu it." In Japanese mokusatsu is a rather ambiguous word, rather untranslatable into English, and "certainly not by a single word, for there is no English equivalent."

"Regrettably," it has been written, "the junior State Department official in charge of translating the Japanese reply lacked the necessary linguistic sophistication, and missed the subtle subtext of the reply altogether. Instead, he reached for a Japanese-English dictionary and translated mokusatsu by the closest single-word English equivalent, which happens to be 'ignore': 'We ignore the Potsdam Declaration."' Which was also interpreted by the press in the United States and the United Kingdom as "We reject it." 
The result? The Allies took the statement as rejection of the Potsdam Declaration, and two atomic bombs were dropped on Hiroshima and Nagasaki, on the 6th and 9th of August.

Se non è vero, è ben trovato, because this is how History is made, how it has been made throughout the centuries, threading its way through the silent protagonism of translated texts - so silent, indeed, that we are not fully conscious of how many strings translations may have pulled all along the centuries.

Of course, there are many other gaps and "blank spaces" in the history of translation that could have been mentioned here: areas so far very little attended to, even clearly neglected and overlooked along the main axes of time and space:

- interesting debates and controversies, such as the thirty-year debate on translation between Jerome and Augustine, Rufinus, Pammachius, Oceanus, and several others, during the last decades of the fourth century and first decades of the fifth century;

- the incorporation of minority and/or minorized languages into translation history research;

- the impact of translations on many literary processes, the provision of new models for national literatures, and the influence of translations on the birth and development of new genres in some target polysystems (genres such as western novels, detective stories, science fiction, fantasy novels, even comics);

- the introduction through translation of new cultural, aesthetic, or political values;

- and above all, maybe before anything else, the urgent task of deWesternizing the history of translation.

Translation in Latin America, for instance, has hardly attracted the historian's attention: it is an uncultivated land still waiting to be ploughed. Five years ago Georganne Weller, Co-director of the Center of Applied Linguistics, Mexico City, remarked that "in general, and with a few notable exceptions, little attention has been paid to the history of translation and interpretation in Mexico by related professions, academic institutions, and professional associations." The same, 
or very similar, words could be said of Chile, Brazil, Argentina, Venezuela, or Peru.

It may be my fault, but the truth is that I have never come across any mention, for instance, of the first printed translation from English into Spanish, which was made in Peru in the year 1594. An English ship, the Dainty, had been captured, and its captain, Richard Hawkins, arrested and charged with piracy. That was on the 22nd of June, after Hawkins had attacked Valparaíso. During the first days of August, Hawkins wrote a letter in English to his father, Sir John Hawkins, to inform him of what had happened. The Spaniards hastened to learn the contents of the letter, translated it, and printed it at once in Lima. It is only a short pamphlet of fourteen pages, lacking even a title page; it just starts with a modest heading, of this tenor: TRASLADO / DE VNA CARTA DE / RICARDO HAVQVINES, ESCRITA / en el puerto de Perico, en seys de Agosto, / de. 1594. años para embiar a su padre / Juan Hauqvines a Londres, tradu / zida de lengua Inglesa en lengua Castellana. [Translation of a letter by Richard Hawkins, written at the harbour of Perico on the 6th of August, 1594, to be sent to his father, John Hawkins, in London, translated from English into Spanish]. As far as I know, a single copy of this letter has survived ${ }_{i}$ it is now in the British Library.

The history of interpretation, the daily practice of translation, lost originals which only survive in translation, old theoretical and critical traditions of the East and Middle East which must be added to the already known tradition of the West, pseudo- and self-translations, translations as agents of History . . . gaps and blank spaces in a chronicle of four thousand, five hundred years, fragments of an unfinished picture, tesserae of a mosaic still waiting to be filled in. The task involved is immense, and there is much doubt that historians of other disciplines or cultural areas would be inclined to take it over (they haven't so far). Neither is it going to be the task of one generation, not even two, because, to echo a familiar saying, "The harvest truly is great, but the labourers are few."

"Sunt autem et alia multa . . . , quae si scribantur per singula, nec ipsum arbitror mundum capere posse eos, qui scribendi sunt, libros." These are the very last words of the Gospel according to John in the 
Latin translation by Eusebius Jerome. Certainly, it is quite probable that when all these and many other blank spaces have finally been filled up, we historians of translation will also be able to repeat them, at least in the more understandable King James version: "There are also many other things [in the history of translation] . . . the which, if they should be written every one, I suppose that even the world itself could not contain the books that should be written."

\section{JULIO-CÉSAR SANTOYO University of León}

(Spain)

\section{Notes}

1. This article was first presented as a lecture in Winnipeg, at the University of Manitoba. Although the author quoted Santayana's words, he adapted them for the occasion by referring to the local institution and city.

2. http://language.home.sprynet.com/trandex/histrhis.htm, 5 (review of the book Translators through History; consulted May 2004).

3. http://language.home.sprynet.com/trandex/histrhis.htm, 1 (consulted May 2004).

4. Anthony Pym: http://www.fut.es/ apym/on-line/reviews/roland.htm, 1 (consulted May 2004).

5. http://www.fordham.edu/halsall/basis/bede-book1.html, chapter XXV (consulted May 2004).

6. In this respect the reader may look in vain for information, for instance, in Peter Russell's Traducciones y traductores en la Península Ibérica 1400-1550 (1985), Louis G. Kelly's The True Interpreter: A History of Translation Theory and Practice in the West (1979), or Frederick M. Rener's Interpretatio: Language and Translation from Cicero to Tytler (1989).

7. Many thanks to Christine York for translating the French quotations in this paper.

8. http://www.earth-history.com/Judaism/Josephus/josephus-wars-pref.htm, 1 (consulted May 2004).

9. New American Bible: http://www.usccb.org/nab/bible/sirach/intro.htm, 2 (consulted May 2004).

10.http://www.folger.edu/institute/jamestown/c_griffin/htm, 3 (consulted May 2004).

11. http://www.atanet.org/conf99/v.htm, 4 (consulted May 2004). 


\section{References}

Al-Jâhiz, Abû Utmân. (1938). The Book of Animals (Kitâb al-bayawân). Vol. 1. Cairo: Hâroun.Allison, Henry E. (1975). Benedict de Spinoza. Boston: Twayne Publishers.

Badawi, Abdurrahmân. (1968). La transmisión de la pbilosopbie grecque au monde arabe. Paris: Librairie Philosophique J. Vrin.

Ballestero Izquierdo, Alberto. (1998). Diccionario de Traducción: Traducciones y traductores en Navarra, siglos XV-XIX. Pamplona: Ediciones Eunate.

Balliu, Christian. (2001). "Les traducteurs: ces médecins légistes du texte." META, 46:1, 92-102.

Bassnett, Susan. (1980). Translation Studies. London and New York: Methuen, London and New York: Routledge, 1991.

Bassnett, Susan, and André Lefevere. (1998). "Where Are We in Translation Studies?" In Constructing Cultures: Essays on Literary Translation. S. Bassnett and A. Lefevere. Clevedon: Multilingual Matters, 1-11.

Berman, Antoine. (1984). L'épreuve de l'étranger: Culture et traduction dans l'Allemagne romantique. Paris: Gallimard. (Trans. S. Heyvaert. [1992]. The Experience of the Foreign: Culture and Translation in Romantic Germany. New York: State University of New York Press).

Blake, N. F., ed. (1972). Middle English Religious Prose. London: Edward Arnold.

Caillois, Roger, ed. (1949). Charles-Louis de Secondat, Baron de Montesquieu: Oeuvres complètes. Vol. 1. Paris: Gallimard.

Chang, Lesley-Ann. (1994). "Translating Ideas vs. Translating Words: A Breakdown of the Situation in Medieval France." SENDEBAR [Granada], 5, 17-26.

Clanchy, Michael. (1979). From Memory to Written Record: England 1066-1307. Oxford: Blackwell.

Das, Sisir Kumar. (1994). Introduction to The English Writings of Rabindranath Tagore. Vol. I: Poems. New Delhi: Sahitya Akademi.

Duarte, Joâo Ferreira. (2003). "Translation and the Space of History." The European English Messenger, XII:1, 16-20.

Fitch, Brian T. (1988). Beckett and Babel: An Investigation into the Status of the Bilingual Work. Toronto, Buffalo, and London: University of Toronto Press.

Foz, Clara. (1998). Le traducteur, l'Église et le roi: Péninsule Ibérique, XIIe et XIIIe siècles. Ottawa: Presses de l'Université d'Ottawa; Artois: Presses Université.

Gil, José S. (1985). La Escuela de Traductores de Toledo y sus colaboradores judíos. Toledo: Instituto Provincial de Investigaciones y Estudios Toledanos.

González Palencia, Angel. (1942). El arzobispo don Raimundo de Toledo. Barcelona: Labor.

Grutman, Rainer. (1994). "Honoré Beaugrand, traducteur de lui-même." Ellipse, 51: 45-53. 
Gutas, Dimitri. (1998). Greek Thought, Arabic Culture: The Graeco-Arabic Translation Movement in Baghdad and Early 'Abbâsid Society (2nd-4th / 8tb-10th Centuries). London and New York: Routledge.

Hermans, Theo. (1999). Translation in Systems: Descriptive and System-Oriented Approaches Explained. Manchester: St Jerome Publishing.

Horguelin, Paul A. (1981). Anthologie de la manière de traduire. Montréal: Linguatec.

Hugonnard-Roche, Henri. (2001). "Les traductions du syriaque." In Les traducteurs au travail: Leurs manuscripts et leurs méthodes, ed. Jacqueline Hamesse. Turnhout: Brepols, 19-49.

Joly, Jean-François. (1995). "Preface." In Translators tbrough History. Jean Delisle and Judith Woodsworth. Amsterdam-Philadelphia: John Benjamins.

Kálmán, G. C. (1993). "Some Border Cases of Translation." In Translation in the Development of Literatures: Proceedings of the XIst Congress of the International Comparative Literature Association, ed. José Lambert and André Lefevere. Leuven: Leuven University Press, 69-72.

Lemarchard, Marie-José. (1995). “¿Qué es un texto 'original'?: Apuntes en torno a la historia del concepto." In Culturas sin fronteras: Encuentros en torno a la traducción, ed. Carmen Valero Garcés. Alcalá de Henares: Universidad de Alcalá de Henares, 23-30.

Lewis, Bernard. (1982). The Muslim Discovery of Europe. New York and London: W. W. Norton.

Miller, Grady. (1999). "The Author as Translator." In ATA Spanish Language Division: Selected Spanish-Related Presentations. St. Louis, Missouri: ATA 40th Annual Conference, 11-17.

Montesquieu, Baron de [Charles-Louis de Secondat]. (1949). Oeuvres complètes, ed. Roger Caillois. Vol. I. Paris: Gallimard.

Nadler, Steven. (1999). Spinoza: A Life. Cambridge: Cambridge University Press. Pereña, Luciano. (1989). Proceso a la Leyenda Negra. Salamanca: Universidad Pontificia de Salamanca.

Popovič, Anton. (1976). Dictionary for the Analysis of Literary Translation. Edmonton, Alberta: University of Alberta, Department of Comparative Literature.

Pym, Anthony. (2000). Negotiating the Frontier: Translators and Intercultures in Hispanic History. Manchester: St Jerome.

Rajak, Tessa. (1984). Josepbus: The Historian and bis Society. Philadelphia: Fortress Press.

Robinson, Douglas. (1997). Western Translation Theory from Herodotus to Nietzsche. Manchester, UK: St Jerome Publishing.

Romano, David. (1991-92). "Hispanojudíos traductores del árabe." Boletín de la Academia de Buenas Letras de Barcelona 43, 211-232.

Ruiz Casanova, José Francisco. (2000). Aproximación a una bistoria de la traducción en España. Madrid: Cátedra. 
Salama-Carr, Myriam. (1990). La traduction à l'époque abbaside. Paris: Didier.

Santoyo, J. C. (2003). "Un quehacer olvidado: los intérpretes-traductores de navíos." In Historia de la traducción, eds. B. Lépinette and A. Melero. Valencia: Universitat de València, 1-21.

Santoyo, J. C. (1997). "Traducciones cotidianas en la Edad Media: Una parcela olvidada." Livius, 9, 159-186.

Shuttleworth, Mark, and Moira Cowie. (1997). Dictionary of Translation Studies. Manchester, UK: St Jerome Publishing.

Swanton, Michael, ed. (1979). Anglo-Saxon Prose. London: Dent.

Tanqueiro, Helena. (2000). "Self-Translation as an Extreme Case of the AuthorTranslator-Dialectic." In Investigating Translation: Selected Papers from the 4th International Congress on Translation (Barcelona 1998), ed. Allison Beeby et al. Amsterdam-Philadelphia: John Benjamins.

Toury, Gideon. (1995). Descriptive Translation Studies and Beyond. AmsterdamPhiladelphia: John Benjamins.

Van Hoof, Henri. (1986). Petite bistoire de la traduction en Occident. Louvain-laNeuve: Cabay.

Whyte, Christopher. (2002). "Against Self-Translation." Translation and Literature, 11:1, 64-71. 
This page intentionally left blank 


\section{The Impact of Postmodern Discourse on the History of Translation}

Introduction

T $\mathrm{t}$ can be safely argued that over the last couple of decades the discipline of translation history has broadened its horizon beyond mainly Western traditions to include other histories and historical perspectives, thus ensuring pluralism as a basis for constituting a truly comprehensive history of translation. This has generally been a healthy response to Berman's (1984) assertion that there can be no truly comprehensive theory of translation without a preliminary study of the many and varied histories of translating languages and cultures. It is therefore interesting to look at some of the ways in which translation history has managed to keep up with the times, especially with respect to the developments of ontological concepts or research paradigms such as postcolonialism, cultural studies, and postmodernism. In spite of the progress made so far, particularly in keeping with current trends in the humanities and the social sciences, the history of translation is still largely viewed essentially as the straightforward documenting of past translating practices and theories, how these relate to the present, and how they can help us 
chart the course to the future. In this regard, translation history is often appraised as a subdiscipline of translation studies, mainly secondary in nature, and translation historians as mere archivists whose main task is to record and document the various trends and discourses that hold sway within the ever-expanding discipline of translation studies. In other words, translation studies has turned to its history to give it depth, recognition, and authenticity. Translation historians, therefore, are made to shoulder a great responsibility since the ultimate achievement of the discipline's lettre de noblesse has a great deal to do with how translation historians present the events of the past, and analyze and relate them to the present, with a view to paving the way to the future.

Given the seriousness of the translation historian's task and in light of recent developments in translation studies, it is indeed within reason to seek to establish translation history as an autonomous discipline with its own objectives and methodologies. Two main points need to be explored here with respect to methodology and how it relates to current trends in historical research. First of all, a clear and rigorous methodology must be established for the history of translation if it is not to be written off as mere "journalism," a linear (or straightforward) recounting of past events within the confines of various linguistic, or cultural, traditions. A good starting point that might lead to such a methodology is for translation historians to start viewing themselves as such - that is, as historians - rather than as translation scholars or practitioners masquerading as historians. For this, the translation historian must view his or her duty as two-pronged, with one eye on the main object of study (that is, translation-related discourses) and the other on the academic discipline of history, keeping abreast with the latter's evolving theories and methodologies.

As history is mostly recounted from the vantage position of the present, there have been many theories of history and varied approaches to relating historical knowledge, all deriving from an attempt to recover and represent the past in an ever-changing present. Alun Munslow (1997) groups the various approaches under three main categories: a. RECONSTRUCTIONISM, based on the correspondence 
theory of empiricism, firmly rooted in the belief that truthful meaning can be directly inferred from primary sources. It is, in other words, the belief in an "objective" recounting of historical facts; b. CON STRUCTIONISM, essentially a subspecies of reconstructionism but with the recognition of the frailty of the correspondence theory of empiricism $_{i}{ }^{1}$ and c. DECONSTRUCTIONISM, ${ }^{2}$ based on postmodernist thought ${ }_{i}$ deconstructionist history is critical of traditional assumptions of empiricism couched as factual, objective and disinterested analysis, and contends that written history results from culturally determined and power-related interpretations [Munslow 1997, 20-26]). Munslow states:

Historians of the deconstructionist or linguistic turn, like others aware of the indeterminate character of postmodern society and the self-referential nature of representation, are conscious that the written historical narrative is the formal re-presentation of historical content. This consciousness has emerged in the last quarter of the twentieth century, prompting all historians to think self-consciously about how we use language - to be particularly aware of the figurative character of our own narrative as the medium by which we relate the past and written history. This means further exploring the idea that our opaque language constitutes and represents rather than transparently corresponds to reality, that there is no ultimate knowable historical truth, that our knowledge of the past is social and perspectival, and that written history exists within culturally determined power structures. $(1997,25)$

In some ways, this study highlights the relevance of the deconstructionist approach to history in accounting for the significance of postmodern discourse for translation history. Which leads to the second main point in this paper: that postmodern theories have greatly influenced contemporary developments in translation studies, calling attention to erstwhile neglected research paradigms such as power relations and ideology, sociology and transculturality, gender and postcoloniality. 
These developments must be accounted for in any current and comprehensive narrative of translation history.

\section{Reflections on methodology \\ Deconstructionism and translation bistory}

Deconstructionist history was born in the late twentieth century out of a general dissatisfaction with the traditionalist view of history as an objectivized empiricist enterprise, in which the historian is an impartial observer who merely conveys "facts" grounded in the belief in some reasonably accurate correspondence between these "facts" and the events of the past. For deconstructionist historians, "facts" presented as simple evidential statements are meaningless. Historical evidence is turned into "facts" through the narrative interpretations of historians.

History is indeed a process of translating evidence into facts. As such, "facts" are never innocent, as they are invested with meaning in the process of contextualization undertaken by the historian within the larger process of interpretation. Historians generally construe meaning and impose their views on the past as informed by their own cultural situation. Deconstructionist historians therefore argue for a clear "interventionist" approach in analyzing the traces of the past. In their view, history is a narrative interpretation informed partly by the social theories or ideological positions adopted or invented by the historian. This view is in sharp contrast to that of the modernist empiricist historian.

The debate between the modernist empiricists and the postmodernist deconstructionists can constitute a basis for discussing some fundamental questions of methodology in translation history: what is the role of the translation historian in documenting or recreating the past? Is translation history, as a discipline, a mere recounting of past events, a deciphering of the traces of the past, so to speak? Or should the discipline be construed as serious historiography, with a decidedly interventionist role for the translation historian? 


\section{History as deconstruction ${ }^{3}$}

Michel Foucault $(1966,1972,1977)$ has contributed a great deal to the deconstructionist approach to history. In his work he generates some questions about the true nature of history by replacing the empiricist approach with a method of narrative interpretation, by denying a linear historical causality between events and epochs (épistémès), and by doubting the historian's capacity to represent knowledge of the past accurately. Following a Nietzschean and post-structuralist line of thought, Foucault discusses what he views as history's dubious quest for the origin of truth, which he considers to be part of the great myth of Western culture. History, as an interpretative process, is subject to the creation and policing of knowledge, an endless process that can never scratch back far enough to find the original truth. History is also subject to our culturally determined discursive practices through which our linguistically based knowledge is produced. These discursive practices are shaped by what historians can say or do within the confines of what society allows or rationalizes to be true or false, right or wrong, legitimate or illegitimate. Hence, history is a social construction of reality, described by Foucault as the power/knowledge equation. The disciplines of knowledge are therefore entities of control that suppress or allow, exclude or include, that which may be deemed permissible or not. It follows from this that there cannot be only one history, but rather several histories of exclusion (that is, of the marginalized or "other"), of inclusion (the accepted as normal) and of transgression (the normal becoming abnormal). History is therefore viewed as a literary and ideologically self-conscious process of thought. It can never be objective because it is subject to the historian's world view (that is, the time and cultural context of production) and to the power of language to create meaning. ${ }^{4}$

Building on Saussure's distinction of langue and parole, and the arbitrary connection between signifier and signified, Foucault highlights the importance of language in shaping or determining the expression of our life experiences. And since we live in a social world of language, 
language is always loaded with social meaning in much the same way that social structure is created by power relationships. As a medium for describing experience, language is unavoidably ideological, tied to relations of power and therefore never innocent. ${ }^{5}$ We must therefore seek to understand historical evidence not only in terms of its referents in the past but also in terms of the linguistic mechanisms underpinning the creation and constitution of historical knowledge. The implication of this structuralist understanding of language for historians is the arbitrary nature of signs, which casts further doubt as to the accuracy of written historical accounts.

Foucault therefore raises the issue of socially constructed power relationships and their representation in language, and, in historical terms, "the connection between the will to truth and the will to power" (Munslow 1997, 128). The reality of the past is viewed as textually generated and ideologically tainted. This postmodernist conception of history translates into Foucault's practical conception of an epistemic imposition on the past, an imposition based on an intellectual culture in which society, ideology, technology and all human behaviour exist (Munslow 1997, 125). The IMPOSITIONALISM of the historian thus celebrated by Foucault calls for an interventionist writing of history, which should be "explicit in its perspective" and should acknowledge that its "perception is slanted, being a deliberate appraisal, affirmation, or negation" (Foucault 1977, 157) of past events. This postmodern approach rejects the modernist perception of history as brute factualism, disinterested and objective representation devoid of ideological input.

\section{Interventionist writing of translation bistory}

From the point of view of translation history, therefore, the question is What is the role of the bistorian in recreating the past? "Interventionism" is not "revisionist" history; rather, it is an attempt to take the historical recording of translation theories and practices beyond the mere recounting of individual histories and traditions - a recounting that has been based on the modernist division of space in terms of a Eurocentric conception 
of nation-states and arranged chronologically according to a mainly Greco-Roman, or Judeo-Christian, sequence of events. A rough sampling of references on translation history would reveal a deep preoccupation with Greco-Roman Antiquity, the Middle Ages, the Renaissance, the Enlightenment, Modernism, and so on. These époques-clés are in themselves major historical landmarks from which the history of humanity can be traced and studied. Yet a cursory look at the literature on translation history leaves one with the impression that these landmarks were mainly great moments in European history, devoid of any significant input from other parts of the world. ${ }^{6}$ To follow Anthony Appiah's line of argument, ${ }^{7}$ one has the distinct impression that

[the Geist — the life of Reason, which is the life of the spirit] had flown from Greece to Rome and then on into the northern forests, residing eventually in what might once have been called the heartlands of the Saxon and Romance races. ... . Hebrew, Sanskrit, and Arabic might be interesting because their literary and philosophical traditions were connected in interesting ways at various points with Europe's. Something very like the Geist may have traveled also through the long literate history of China and its cultural heirs in Japan and the Korean peninsula, but this spirit, the shadow-Geist of East Asia, had its own life and one could responsibly follow the Western Geist without much attention to it. $(1995,52)$

Appiah's statement is critical of a Eurocentric view in comparative literature which initially resisted the inclusion of cultural studies and other postmodern trends. And how is this relevant to the study of translation history? Well, we can learn from this crisis of inclusion in comparative literature by directing research in translation history towards a more broad-based and comprehensive study, which explores the interconnections between histories (between East and West, or between North and South) rather than stressing isolated national traditions centred on the obsolete notion of European nation-states. The history of humanity is expressed in interconnected bodies of writing and experiences, and 
includes the longstanding role of peoples and products from outside Europe in shaping our intellectual heritage. This interconnection of histories is made evident in the following statement by Appiah.

The Greece to which the West looks back was at the crossroads of cultures of North Africa and the Near East; the Spain that began the conquest of the New World had been deeply shaped by Islam; the Renaissance rediscovery of ancient learning owed a great deal to the Arabs who had preserved that tradition through the European Dark Ages; and the economic basis of modern capitalism depended on the labor of Africans, the gold and silver of the New World Indians, and the markets of Asia.... The West acquired gunpowder — at the military heart of the modern European state - from China and the astronomical data on which was based the beginnings of the Scientific Revolution from the ancient Near East. $(1995,55)$

Studying the interconnections of our histories is therefore relevant to grasping the big picture, as it were. This, however, does not preclude the specific study of some aspects of history such as the constant reflection on a few ancient texts — the Bible, the Torah, Boethius's Consolation of Pbilosopby - which is central to Western civilization. Yet with respect to the nineteenth and twentieth centuries it is unthinkable to study the history of Western Europe without exploring questions of empire, colony, and postcolony. At this juncture Western civilization becomes difficult to disentangle from global civilization, not because Western civilization becomes the culture of the World but rather because the West as a paradigm for cultural history begins to lose its essence as the nation-state did in the European Enlightenment (Spivak 2003).

The historical interconnectedness of the human experience involves a complex dialectic between subject matters, human interests, and professional organizations. This dialectic feeds into the historical process of the construction of a field of discourse such as translation history, which can therefore be conceived as a broad set of multilingual cultural histories of our common civilization. 
Interventionism can therefore propel the writing of translation history beyond the mechanistic juxtaposition of different national traditions in what sometimes amounts to a clustering of mutual admiration societies charged with extolling national pride. Instead of reconsolidating the boundaries of nations through the study of isolated national traditions (in an encyclopedic manner), translation history can become the place where the concept of the nation as the origin of a particular type of translation practice is put to the test. In our current world of globalization, constant displacement of peoples, and relocation of cultures, the concepts of "nationhood," "nation," and "nationalism" are shown to be products of imperialism. Reading the entry on The Arabic Tradition in the Encyclopedia edited by Mona Baker, for instance, it becomes clear that what is called the Arabic tradition is indeed a hodgepodge of influences from the Far East, the Near East, Persia, Greece, North Africa, and so forth, which in turn have influenced the various cultures and traditions of Europe. A certain degree of cross-fertilization, demographic shift, migration, cultural circulation, and hybridization had occurred, which makes it almost a misnomer to speak of an exclusively Arabic tradition. Given such a context, an interventionist writing of history will highlight the symbiotic relations among these cultures, reading "across the imperial divide" (Said 1993) or studying the interplay of hegemonic and counter-hegemonic discourses, or the relations between Western and non-Western cultures.

This approach calls for collaborative work. ${ }^{8}$ How can translation history avoid the boundaries of national traditions? For starters, by studying major themes that cut across individual histories and developing global perspectives. In the current context of globalization, democratization, and postcolonialism, translation history has to rethink its priorities and modes of accountability. Gayatri Spivak points out that one way in which the concept of "nation"(s) is being destabilized (in comparative literature) is by introducing more broad-based concepts like Francophony, Teutophony, Lusophony, Anglophony, and Hispanophony, which unfortunately still follow the lines of the old imperialisms and compete with today's diversified metropolitan reality (Spivak 2003, 9). 
However, this kind of destabilization has the merit of expanding the field of inquiry beyond strict national boundaries and effacing the North-South divide. Also, besides sharing a common international language and culture, the European nation at the centre of such a construct is forced to study its history in relation to its former colonies, thereby accounting for the histories of conquest, cultural exchange, colonialism, and imperialism. ${ }^{9}$ There is also a kind of research work here that one might describe as vertical, relating the global and the local through a study of the history of multicultural empires. ${ }^{10}$ This would take into account the irreducible hybridity of all languages and cultures. In our postcolonial and globalizing world, we are witnessing something along the lines of demographic — rather than territorial — frontiers, responding to large-scale migration and creating the kind of para-state collectivities that belong to the shifting multicultural empires (Spivak 2003, 15). According to Spivak, "The idea of shifting demographic frontiers caught in the virtuality of the Internet and telecommunication is generally assigned to postmodern globalization" $(2003,18)$. These developments call for the reconfiguration of the objectives and methodologies of the study of history. Translation history can thus become a site for intellectual renewal, providing a hospitable space for the cultivation of deep intercultural understanding and a genuinely global consciousness.

\section{Postmodernity and contemporary translation studies}

In the 1990s translation studies witnessed a powerful intellectual renewal which could be recorded in historical terms as the postmodern turn. New approaches to studying translation phenomena revealed the limitations of previous methodologies, bringing to the forefront issues of gender, ethics, postcolonialism, globalization, and minority in translation, all related to what is generally referred to as the postmodern condition. Following the cultural turn (Bassnett and Lefevere 1990) in translation studies of the 1980s, these new approaches raised doubts about long-held views on matters of fidelity, sameness, and binary oppositions (such as the relationship between original and translation), 
introducing other paradigms of investigation such as power relations, ideology, and identity. Translation theory began to acknowledge other definitions of translation ranging from manipulatory rewriting to transformation, subversion, cannibalism, carnivalism, hijacking, and what not (Koskinen 2000). These new definitions, as dramatic or far-fetched as some might seem, had the effect of pointing out the gender, regional, and ethnocultural, as well as the Eurocentric, bias of previous translation theories.

Postmodernity has been described as a critique of modernity which highlights the limitations of modernity - for instance, by revealing the diminishing role or significance of the modernist concept of the nationstate (mentioned earlier). It engages in historicizing or contextualizing our current human experience. Although Jacques Derrida does not use the word "postmodern" to describe his work, his theory of deconstruction is generally acknowledged to be a clear response to the postmodern condition; and so far, it seems to be postmodern thought that is most closely related to the preoccupations of contemporary translation theory. Derrida coined the term "deconstruction" to challenge the fundamental tenet of Anglo-American and European philosophy and reconstructionist history, namely, that there is a stable/knowable reality "out there" that we can access accurately (Koskinen 2000). It is upon such a belief that the basic polarities of real-unreal, fact-fiction, truthuntruth, subject-object, and mind-knowledge were established in Western culture (Munslow 1997, 25). What this implies is that written history is open rather than closed in meaning. For instance, when the history of imperialism is written from a non-European perspective and is not recognized at all as a perspective until the advent of decolonization (second half of the twentieth century), it becomes clear what postmodern history means: a recognition of the relativism of meaning, determined by where one stands historically.

By extension, in literary deconstruction there is no certainty of meaning in language-based texts because "out there" is always encountered as a socially constructed text. Textuality is seen as open to changing interpretations rather than as a system of fixed meanings. 
The central concept of deconstruction is différance (with an "a"), a neologism which Derrida uses to emphasize the point that meanings are "always already" somewhere else, temporally and positionally deferred (Koskinen 2000). Texts are full of echoes and traces of earlier texts as well as laden with the yet unrealized potential future contexts they may enter (Derrida 1972). Some of the central themes of postmodern discourse recall the paradoxes and difficulties of translation. Postmodern preoccupations with issues of cultural hegemony, the unequal relationship between centres and peripheries, the entanglement of ideologies and interpretation, the arbitrary relationship between signs and significations, and so on, are now reflected in the concerns of translation scholars. Inversely, postmodern scholars are also using translation as a tool for studying or rethinking textual relations. In fact, postmodern trends in translation studies can be traced to the 1980s with the advent of the manipulation approach, which related translation practice to issues of power and ideology. Susan Bassnett had referred to this as a post-structuralist phase where translation is conceived "as one of a range of processes of textual manipulation, where the concept of plurality replaces dogmas of faithfulness to a source text, and where the idea of the original is being challenged from a variety of perspectives" $(1993,147)$. The postmodern tendencies in translation studies were reinforced in the 1990s with two distinctively postmodern currents, namely feminist and postcolonial translation theories. For these new trends in translation theory deconstruction has been particularly useful as it seeks to dismantle hierarchical oppositions, and has been used to rethink the roles of source and target texts/cultures as well as the relation between author and translator. The political aspects of translation have been brought to the forefront as research has centred on issues of identity and ideology. Some theorists have even talked of a "postcultural turn," arguing that the classic notion of "culture" is in fact modernist, closely tied in with the idea of nation-states (Bannett 1993). A postcultural theory will therefore take into account the progressive blurring of boundaries between nations and cultures due to the decline of nation-states, rapid 
globalization, and internationalization, as well as new forms of communication.

\section{Conclusion}

The contribution of postmodern theories to translation studies has been quite significant and far-reaching, particularly in regard to matters related to gender, minority, and postcolonialism, as well as questions of ethics in translation theory and practice. In some ways, the significance of all this is borne out in the growing interest and prestige of translation theory and discourses within other academic disciplines. These developments must be accounted for in translation history from a proactive, interventionist perspective, in the hope that translation history will emerge as an autonomous discipline with its own methodologies capable of meeting the challenges of our multicultural future.

PAUL F. BANDIA

Concordia University

(Canada)

\section{Notes}

1. That is to say, reconstructionism's simple descriptive narrative of discrete and singular events (around the 1920s).

2. Fairly recent - the last quarter of the twentieth century.

3. "Events do not dictate history: history dictates events." Foucault, in Munslow $(1997,125)$.

4. "History is the record not of what actually happened, but of what historians tell us happened after they have organized the data according to their own version of social reality" (Munslow 1997, 127).

5. The French cultural critic Jean-François Lyotard generally agrees with Foucault that the narrative is about the exercise of power (The Postmodern Condition [1984]).

6. See Martin Bernal's (1991) lucid account of the deliberate whitewashing of Semitic and Negro-African influences on Greco-Roman civilization.

7. Regarding a perceived crisis in the discipline of comparative literature.

8. A step in this direction is the conference on "Translation Theory and 
Practice: East and West," organized by Theo Hermans in London in 2002-2003.

9. This is not to say that the ex-colonies should sit back and let their histories be written by the former colonial masters.

10. To put some black on the Union Jack, so to speak (recalling the initial Birmingham model of Cultural Studies).

\section{References}

Appiah, Anthony K. (1995). "Geist Stories." In Comparative Literature in the Age of Multiculturalism, ed. C. Bernheimer, 51-57. Baltimore: John Hopkins University Press.

Baker, Mona. (1995). Encyclopedia of Translation Studies. London: Routledge.

Bannet, Eva Tavor. (1993). Postcultural Theory: Critical Theory after the Marxist Paradigm. London: Macmillan.

Bassnett, Susan. (1993). Comparative Literature: A Critical Introduction. Oxford, UK/ Cambridge, MA: Blackwell.

Bassnett, Susan, and André Lefevere, eds. (1990). Translation, History and Culture. London and New York: Pinter Publishers.

Berman, Antoine. (1984). L'Épreuve de l'étranger. Culture et traduction dans l'Allemagne romantique. Paris: Gallimard.

Bernal, Martin. (1991). Black Athena: The Afroasiatic Roots of Classical Civilization. London: Vintage.

Derrida, Jacques. (1972). Positions. Paris: Minuit.

Foucault, Michel. (1966). [1994]. The Order of Things: An Archaeology of the Human Sciences. New York: Vintage Books.

Foucault, Michel. (1972). The Archaeology of Knowledge. New York: Pantheon.

Foucault, Michel. (1977). "Nietzsche, Genealogy, History." In Language, Counter Memory, Practice: Selected Essays and Interviews, ed. Donald F. Bouchard, trans. Donald F. Bouchard and Sherry Simon. Ithaca: Cornell University Press, 139-164.

Koskinen, Kaisa. (2000). Beyond Ambivalence. Tampere, Finland: Acta Universitatis Tamperensis 774 .

Lyotard, Jean-François. (1979). La condition postmoderne. Paris: Minuit.

Munslow, Alun. (1997). Deconstructing History. London and New York: Routledge. Said, Edward. (1993). Culture and Imperialism. New York: Vintage.

Spivak, Gayatri. (2003). Death of a Discipline. New York: Columbia University Press. 


\section{Conceptualizing the Translator as a Historical Subject in Multilingual Environments \\ A Challenge for Descriptive Translation Studies?}

$\mathrm{D}$ uring the past few years, the study of translation from a sociological point of view has come more and more to the fore within the descriptive translation studies (DTS) paradigm. But as usual in research, the discovery of new research areas is more or less erratic. It is the goal of this discussion to indicate a few shortcomings in these important new fields of questioning.

Among other things, the functional, text- and discourse-oriented approach of DTS has been criticized for "gloriously overlook[ing] the human agent, the translator" (Hermans 1995, 222). The present volume's aim of studying the history of translation, and thus of cultural dynamics and identity construction, would imply investigating how translators, as historical subjects translating for other historical subjects, are implicated in this history. It is striking, then, that "modern sociographies of single translators' professional trajectories are sorely lacking" (Simeoni 1998, 31). But next to biographical research, DTS has to share with any other discipline in the humanities the more fundamental question of the 
relations between the (more/less) individual and the (more/less) collective, between structure and agency. Autopoiesis and self-referentiality indeed have their limits in social systems (Fokkema 1997); communication-oriented paradigms cannot ignore human agency. ${ }^{1}$ By focusing on how and to what extent varying and variable (translational) norms influence the translator's choices in the makeup of the translated product, DTS has until recently privileged structure instead of agency. Especially actor- and institution-oriented approaches like Bourdieu's field theoretical model (Bourdieu 1971, 1991, 1992) have been advanced as a welcome sociological corrective (Simeoni 1998). ${ }^{2}$ As regards the human agent and its relations with collective structures, the usability of field theory's habitus concept for a functional, text- and discourse-oriented model of interlingual translation deserves closer investigation.

"Habitus" refers to the subject's internalized system of social structures in the form of dispositions. The inculcation of social structures is a lifelong process of interactions between structure and agency through various and variable individual and collective experiences. Dispositions engender practices, perceptions, and attitudes that are regular but not necessarily fixed or invariant. Under the influence of its social position and its individual and collective past, every cultural actor thus develops (and continues to develop) a social identity: a certain representation of the world and of his position therein. Habitus is hence designed to be the motor of dialectic between a theory of effects and a theory of strategies; it wants to escape a philosophy of the subject without sacrificing the agents and to escape a philosophy of structure without refusing to take into account the effects it exerts on the agent and through him (Bourdieu 1992, 97). Therefore, it is considered a crucial concept, "at least as a meta-theoretical guideline" (Sheffy 1997, 37).

Nevertheless, the concept suffers from theoretical abstraction and methodological imprecision. Fine-grained analyses being lacking for a lot of field logics, and especially for intercultural contacts, habitus seems to confirm all too often the precedence of structure over agency. It has therefore - and rightly so - frequently been criticized for being deterministic, static and one-directional (Sheffy 1997, Geldof 1997). It is 
too much linked to the uniqueness and the permanence of the individual (Corcuff 2003) and does not account for the possible plurality of his/ her dispositions and identities, and therefore it does not allow for the heterogeneity and dynamics of cultural choices, nor for individual variations within a given social formation (Sheffy 1997). It presents actors too much as "cultural dopes" (Corcuff 2003) that depend on structures without any reflexivity, dynamics, internal tensions.

Recent insights, however, insist on habitus as a dynamic, plural concept, as the object of confrontations with various field logics and thus of multiple definitions and discontinuities. Every cultural actor appears as a complex product of multiple processes of socialization disseminated in various institutions (family, school, friends, work, neighbourhood, and so on). His (or her) attitudes, perceptions and practices are the result of an unstable interplay of multiple kinds of habituses, questioning the uniqueness and permanence of the individual person (Simeoni 1998; Lahire 2001). Nevertheless, sociology, in particular the Bourdieu tradition, is too much linked with structures and agents that refer to national societies only. How could one deal with cultural situations before and/or after the nation-state? We thus need to adapt our conceptualization. Societal frameworks are not - all - simply national; they can even be neither international nor national. Intercultural agents, involved in intercultural relationships, develop perceptions and practices partly through crosscultural habituses.

\section{Geography and/versus habitus?}

The study of (inter)cultural actors' various and variable perceptions, attitudes and practices as structured by - and structuring in their turn - their (intercultural and other) habituses is an essential complement to translation studies' habitual analysis of microtextual and macrotextual translation strategies, of discursive practices with regard to the Other, of socio-institutional and geopolitical structures. The following principle seems crucial in this respect: the less geography is a distinctive 
feature between languages, literatures, and cultures, the more the actor's habituses play a key role in their definition and in the understanding of intercultural dynamics. It has often been repeated that in our globalized, postcolonial world, "space" is less and less pertinent: modern communities identify themselves partially in interaction with institutional and discursive structures that are not bound by geographical limits (Lambert 1991, 1996). But deterritorialization was an interesting component in the history of mankind long before virtual societies had been invented. Among other things, an integrated analysis of the relationships between structure and agency will prove particularly pertinent for translations taking place in one and the same geopolitical, multilingual environment. Space being irrelevant, in a multilingual society, (intercultural) actors perceive their (inter)cultural positions and develop their (inter)cultural position takings in dialogue with institutional and discursive structures that are intimately linked with the sometimes competing - concepts of "language," "culture," "translation," and intercultural relationships.

It would of course be utopian to analyze these relationships without focusing on particular situations and cases. But on the other hand, any kinds of peculiarities also need to be located within larger frameworks. As suggested at the beginning, both the individual and the collective derive their perspective and depth from their positions and interrelationships. How general and how particular are the features and phenomena under observation? These are both descriptive and conceptual key issues. This means that the following case study can also hold interest in terms of what it reveals about similar or different landscapes in our "world systems."

Why and how is a sociological approach integrating the habitus concept necessary to grasp the dynamics of literary translations from Flemish into French in interwar Belgium? ${ }^{3}$ Belgian society, and in particular its most fundamental societal evolutions, are closely interwoven with what is commonly called the "language question." This language struggle was - and continues to be - a principal point of contention, crystallizing social positions and often even paralyzing sociopolitical 
life. Research on the fundamental institutional, sociopolitical, and sociocultural role of translation and intercultural contacts in this multilingual society is, however, underdeveloped. ${ }^{4}$

From Belgium's foundation in 1830 until about 1935, French was the country's official language for state administration, justice and education. Belgium thus institutionalized the romantic principles of the WestEuropean nation-state, whose structures rely on a standardized national language functioning at the same time as one of the most powerful symbols of popular unification and national identification (Anderson 1991). Until about the 1930s, knowledge of French conditioned access to prestigious primary and secondary schools, to university education, to higher-level jobs, to a national political career, to the most legitimate literary productions, and so forth. In this regard, language functioned as one of the major elements of sociocultural distinction. Linked with the nation-state's fundamental sociopolitical institutions, it generated various sociolinguistic habituses in interaction with the individual's social position as well as individual and collective antecedents and experiences. Indeed, people's access to the legitimate language and the accompanying institutions was uneven. Belgium was a multilingual country where the individual's language use was determined by the combined parameters of geography and social class. The lower classes were often illiterate ${ }^{5}$ and used various geographically differentiated dialects as a vernacular, that is to say, a number of Flemish dialects in the North and French (Walloon) dialects in the South. Standard French was the upper classes' language all over the country. Especially the North, then, where Flemish coexisted with French, was a multilingual space. ${ }^{6}$ Moreover, Flemish-French bilingualism as an individual's characteristic was the normal condition of the Flemish middle classes. Indeed, these groups often used Flemish in private, and certainly for contacts with lower classes the local dialects served as a vernacular. But motivated by progressing chances for social promotion in an industrializing society, a lot of their members gained access to French schools where Flemish language and culture were disdained to the point where one was punished for speaking Flemish. Internalizing the sociolinguistic hierarchies 
through interaction with such institutions and experiences, a number of them also turned to French in public life, in professional life, in contacts with the upper classes, and sometimes even at home, as a means of sociocultural distinction and mobility.

Within one and the same geopolitical space, languages and cultures thus coincided with sociopolitical structures and (op)positions. French being the national language and the language of the ruling classes, it was synonymous with culture, education, prestige, social distinction, and mobility. In other words, the sociolinguistic habitus of the average Flemish, francophone, or bilingual adult of the interwar period was formed in interaction with socio-institutional structures that unambiguously confirmed the superiority of the French language and culture. Social discourse as a whole, both in French and in Flemish, continuously externalized these perceptions, sociolinguistic oppositions thus being one of the major structuring principles of discursive practices during the interwar period.

Already before the twelfth century, the French language was introduced in Flanders in the most natural way, without any pressure in favour of it, by the free course of civilization and of contextual conditions. Since the twelfth century, French had become a second national language for the leading classes. . . . French is a language of universal importance, which is not the case at all for Flemish. Moreover, a lot of the Flemish, especially the bourgeoisie and the intellectuals, prefer to use, often exclusively, French. We can thus see that we can have equality of rights for the two languages. But it is impossible to have factual equality, for the simple reason that a law, even a royal speech, cannot make one equal ten. (Wullus-Rudiger 1929, 7; our translation)

But as already mentioned, dispositions are not fixed or invariant imprints of structures; the latter can actually evolve through agents' (inter) actions. From the second half of the nineteenth century on, dominant groups within the Flemish middle classes claimed Flemish institutions 
for the Flemish. They lobbied so that a standardized form of Flemish could become the official language in the North for state administration, justice, and education. Internalized sociolinguistic inferiority as a collective sociolinguistic habitus was thus, little by little, challenged. Although most of them had themselves been in francophone school and/or university, were often employed in francophone administration, and in some cases even fulfilled a political role in francophone political institutions, these bilinguals struggled against the privileged position of French in the nation's institutions; it would impede social mobility because of the supplementary exigency of bilingualism imposed on the Flemish. The francophone upper classes, with their superior sociolinguistic habitus, perceived the new claims as a threat to their political and sociocultural hegemony. As a consequence of the instauration of universal suffrage after World War I the Flemish lower classes' political weight increased gradually. As a result, important linguistic laws made Flemish the official language for administration, education, and justice in Flanders at the beginning of the 1930s. However, it is important to stress that these legal measures and the new structures they progressively brought about did not immediately change the sociolinguistic habitus of the cultural agents. For several decades it partly continued to be structured around formerly internalized schemes, keeping intact the association between the French language and sociocultural distinction. ${ }^{7}$

\section{Who has the right to be(come) a translator?}

In interwar Belgium, "language," "literature," "translation," and other forms of intercultural contacts thus functioned as ideologically very loaded categories. The sudden boom of literary translations from Flemish into French in the 1920s and 30s is really significant in this respect. ${ }^{8}$ It accentuated the ideological and sociocultural fault lines of Belgian society and constituted a statement about its cultural identity. Since (inter)cultural practices among actors living within this geopolitical and institutional space were inevitably linked with sociopolitical and sociolinguistic structures and oppositions, and with various and varying 
collective and individual sociolinguistic, sociopolitical, and literary habituses, a close investigation of these interculturals' habituses is a necessary aspect of the study of intercultural dynamics.

The sudden increase of literary translations from Flemish into French in the Belgian interwar period was a defensive response of the francophone upper classes to the Flemish sociocultural and sociopolitical emancipation claims. The translations were seen as a patriotic act in service of the francophone nation and its national, francophone literature. They would help to overcome linguistic and sociopolitical tensions by bringing together the two cultures.

What book written in French could tell me something about contemporary Flemish literature? .. . This needed book has finally been published: it is Flemish Contemporary Literature by M. André De Ridder. I recommend this work to all Belgians who don't understand Flemish. I hope for them that they, like myself, feel a strong desire to know this literature. I hope that they don't turn away from the Flemish and from the Flemish soul because of the linguistic quarrels that oppress the internal politics of our country. On the contrary, just because of these quarrels it is important that we come to know the soul of the Flemish people. They are, like us, natural intermediaries between German and Franco-Latin civilization. (Gilkin 1924, 492; our translation $)^{9}$

At the same time, translation into French functioned as a way to delegitimize Flemish as a literary language. Flemish works had to pass through French translation in order to exist and gain prestige. The underlying francophone's perception was that writing in Flemish signified a questionable sociopolitical plea for the emancipation of the Flemish minority culture. Indeed, since Flemish writers belonged to the middle classes who had normally been to French schools, most of them were perfectly bilingual. In theory, they could have chosen to write in French instead of Flemish. 
Most uncommon also was that this bourgeois child, raised in French, decided to write in Flemish, an extremely dispraised language at the time; but since it was the language of the little people among whom he lived every day and whose lifestyle he wanted to paint in his future work, he chose it simply as the language of his works without any ulterior motive of linguistic claims. (Maes 1932, 312; our translation)

This was exactly the reason why writing in Flemish was promoted by the Flemish. From the 1930s on, fewer and fewer Flemish bilinguals chose French as their literary language.

Needless to say, this also strongly affected the positions and position takings of the translators. Belgian interwar interculturals were in an unenviable situation: they had to hover between competing views on languages, literatures, cultures, and translation. Who was, or better, who had the right to be a translator became a crucial question then. Given the prevailing sociolinguistic structures, the bilingual Flemish middle class had the highest potential to deliver translators. Due to lack of instruction, the Flemish lower classes had insufficient knowledge of French. For the francophone, on the contrary, learning Flemish, the disdained language of the minority culture, was of no sociopolitical or sociocultural necessity. But belonging to a source culture that struggled against the target culture for its sociolinguistic emancipation within one and the same multilingual geopolitical space, these translators of Flemish origin had to deal with radically opposed and sometimes problematic cross-cultural habituses. Those Flemish colleagues who had internalized their linguistic and literary inferiority to the point that they hoped to gain legitimacy through participation in the dominant culture were in favour of intercultural contacts. Translations into French were welcomed as a sign of francophone admiration and as a form of active and most effective propaganda for the distribution of modern Flemish literature. Translators were appreciated for doing an excellent job. ${ }^{10}$ In contrast, Flemish groups fighting against their internalized linguistic and literary inferiority, in favour of access to Flemish structures for the 
Flemish, staunchly attacked translations and other types of intercultural contacts. For emancipationist Flemish bilinguals, to translate was to betray: it confirmed and prolonged the monolingualism and thus the sociocultural superiority of the francophone upper classes. The emancipating milieux of a dominated source culture within a multilingual space form thus an obstacle to intercultural contacts; their ideal is nontranslation.

It behoves André De Ridder to have written out of dilettantism a thin booklet about "Les Lettres flamandes," whereas for a Flemish person this could as well and probably even better have happened in Flemish. . . . I foresee an easy answer. "Do exclusively French-speaking people not have the right to be informed about Flemish literature?" The privilege, you mean? Because I consider it as a more or less doubtful privilege to be able to lick in such playful manner the lentil dish that in these circumstances is best kept for us alone. This is not the way that any of us, bourgeois kids raised in French, took possession of the treasure of a foreign literature! It would be much more logical if the French-speaking Belgians would learn the Dutch language in a decent manner in order to become happy possessors of the sane centre of our literature. (Van Den Oever 1908, 515; our translation)

The French translations and other intercultural activities evoked reactions in the source culture that made the position of the Flemish intercultural professionals quite ambiguous and every so often even untenable. They had to deal with sometimes problematic cross-cultural habituses, being treated as traitors of the Flemish culture and of the Flemish sociopolitical cause.

In fact, in all the writings from the Ruimte group against me, that is the only thing that could hurt me: that they insisted on treating me as a "franskiljon." The fact that one runs a French journal points not towards "franskiljonism," believe me, but towards spiritual international- 
ism. The reason for founding "Signaux" has only been personal friendship and like-mindedness with French writers. . . No politics was involved. (Letter from André De Ridder to E. De Bock, 19 September 1922 [AMVC R462]; our translation)

Disillusioned by these reactions, they often stopped their intercultural activities. $^{11}$

\section{Who has the obligation/mission to remain a translator?}

At first sight, the most important translator of the interwar period ${ }^{12}$ didn't have to care about these kinds of negative reactions because he was of francophone origin. Roger Kervyn de Marcke ten Driessche was one of the typical upper-class adults of the interbellum period. He was born in Ghent (Flanders) in 1896 but lived mostly in Brussels. Son of a francophone Flemish aristocrat and a Dutch mother, he was raised in French, in full accordance with the sociolinguistic habitus of the time. Still, from his early childhood on, he also became familiarized with Flemish through his mother's family, through contacts with domestic servants, and in the streets of Ghent and Brussels. In 1904, after the death of his father, the family moved to a Brussels neighbourhood that was chic but also very near to the Marolles, the most famous popular quarter of the city. The Marolles was known for its picturesque language: a mixture of Brussels Flemish and French dialects. Kervyn went to a very prestigious francophone secondary school where speaking Flemish was forbidden. Among other things, these factors would have contributed to the child's internalization of the superiority of the French language and culture. At the same time, and more than the average francophone child of his milieu, he was in contact with the popular, bilingual world of the Marolles. The child had to pass the area on his daily way back and forth to school. More than once he was so fascinated that he forgot time and arrived late. His multilingual experiences left their traces in his later works. In his most famous book Kervyn constructed a literary variant of the Marolles dialect (Kervyn 1923, Meylaerts 1999); in 
other works Flemish words or sentences pop up in the French text (Kervyn 1954).

After secondary school, Kervyn studied law at university, a completely francophone institution at the time. But he very quickly regretted his choice because it was only inspired by the expectations of his social class. "I never liked law studies," he confessed, "and if I became a lawyer it is perhaps because of a lack of pugnacity, because I didn't resist pressure from part of my entourage that wished it" (Kervyn 1934, 23; our translation). He rather quickly abandoned this profession to become a writer.

A Flemish francophone aristocrat, Kervyn belonged to the upper classes that cherished the francophone nation and were opposed to the Flemish sociolinguistic emancipation claims. Both his works and his correspondence contain evidence of these dispositions.

The thing, thus, could be summarized as follows: in one of the smallest countries of the smallest part of the world, which is itself a rather small planet in our solar system, which is not the biggest, a handful of people who speak bad French quarrel with a handful of others who would like to oblige them to speak - like them — bad Flemish. (Kervyn 1934, 96; our translation)

Aristocracy means "the rule of the best." It is also these best who because they are the best - govern, occupy the leading positions (forgive me this cliché!). But, are we the best? And what leading positions have we occupied? . . have been left to us? . . Besides, the people and the bourgeoisie, have they enough lamented the fact that one did not allow them free access to everything they wanted! "I don't achieve anything; the nobles and the franskiljons get everything." "I don't achieve anything; the democrats and flamingants get everything." Isn't it easy to hide one's own inertia behind those excuses? (Kervyn 1954, 83-84; our translation).

But Kervyn also became the most important translator of Flemish regionalist novels during the interbellum period in Belgium. The trajectory is 
remarkable. Due to a number of sometimes rather accidental individual experiences in interaction with specific sociolinguistic and sociocultural structures in a particular geopolitical context, this aristocrat had enough knowledge to translate from Flemish, a language at the time mostly ignored if not dispraised by his social milieu, but finding at that very same moment its way through the nation-state institutions. And his translations were most successful; the translator, to a large extent sharing his sociolinguistic and cultural habitus with his target public, brilliantly interpreted its aesthetic tastes. All his translated texts belonged to the regionalist genre, naively portraying the everyday life of the lower and middle Flemish classes in small villages. In the eyes of the francophone upper classes, the novels' plots confirmed all the clichés of an ideal world where "Flemish" continued to be synonymous with popular life and backwardness - in short, with the lower (or middle) class, a world at a distant remove from the sociolinguistic emancipation claims of some within the Flemish middle classes. ${ }^{13}$ Kervyn's uniform selection strategy gave rise to the label "simply Flemish" among his colleagues and editors. The expression occurred numerous times in reviews, in prefaces, in editors' and translators' letters, and so forth, always with a positive connotation.

I'm looking as much as possible, among the Flemish translations, for works that have a simply Flemish character, like the ones you gave us until now in fact, and in particular this beautiful study of Brussels manners entitled Matbias, about which I received, from numerous sides, the most flattering echoes. (Letter of Pierre Goemaere, editor, to Roger Kervyn, translator, 17 September 1932 [ML4331/475]; our translation)

Moreover, as an example of the socio-stylistics of habitus-governed translating (Simeoni 1998), Kervyn also found the appropriate tone for his translations. Unlike his Flemish bilingual colleagues, he constructed a style perceived as "simply Flemish": a radical and continuous mixture of literary language with more popular, familiar, and vulgar registers, 
resulting in a general lowering of the translations' language in comparison with the originals. It was appreciated by the readers for this popular undertone; often it had a picturesque, comic side effect, again in harmony with the dispositions of the target public, who were only asking for more of the same.

The best thing to do was to come with your wife, a-toddling on her arm. The wife said: "Your honour, there is some change in him. And we have to work so hard to get by!" It worked sometimes, although it couldn't happen too often. (Van Cauwelaert 1932b, 482; our translation of the French translation)

At the peak of his success, and therefore at first sight perhaps rather surprisingly, Kervyn stopped translating. Why does a (successful) translator quit the job? How individual and how collective is such a decision within a given context? From 1932 on, the year in which his reputation as a translator of Flemish literature was firmly established, Kervyn began to express an increasing disdain towards the type of literature he felt obliged to translate. His personal archives contain evidence of this attitude:

Read with discomfort the "Harp van St. Franciscus" of Timmermans. The author — he justifies himself at the end of his booklet — having read the "books" that deal with the Little Poor Man of Assisi, has come up with a plan to produce a version in his own manner for his wife, his children, others also, and "a few simple persons of our street" ... You feel what that must ... what that has to ... what that has to result in! ..." They clapped with their hands like farmers at the mar-

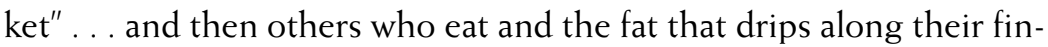
gers and chin. ... Pouah! Melloy would have liked us to translate that together. Really, I think that this is not feasible. . . Moreover, I can't imagine myself writing, for the people of my street, the life of one or another well-known man which I would make, for the circumstance, somewhat vulgar, so as to make him more accessible! (Letter of 
Kervyn to Marcel Lobet, editor, n.d. [August 1932]; ML3858/487; our translation)

The translator wanted to go beyond the expectations of his public and dreamt of translating "modern" Flemish authors. But all his attempts failed because his readers swore by "simply Flemish" novels.

Thank you also for Forum and the Jazzspeler. . . I've done some correspondence this morning and answered Roelants that I would get to work on the translation of the Negerbeeld this same afternoon. . . . Roelants is a "gentleman"; this has nothing to do with skimmed milk or beer, nor with a dampening plate of potatoes. It is not specifically "Flemish," but specifically (I repeat the adverb on purpose) modern. The plot is thin, of course, but in the end I it would work well for the $\mathrm{R}$ [evue] $\mathrm{B}[$ elge]. . . . In a special issue devoted to Flemish literature it would strike a special note next to the simplicities of Buysse and so many others. (Letter of Roger Kervyn to Marcel Lobet [1932] [ML3858/492]; our translation)

His personal aesthetic evolution, probably in some degree due to his more elaborate contacts with Flemish literature, surpassed the more conservative literary and cultural habitus of his readers.

Still, along with this individual intercultural habitus, more collective, structural factors influenced the individual's decision. About the same period Kervyn was very upset by starkly negative reviews of his translations, and of French translations in general, written by Flemish critics in the francophone press. Because of the intersections between (source and target) languages, texts, and discourses in a multilingual space, bilingual Flemish critics did also write for the francophone press. But using the dominant language did not necessarily imply internalizing the dominant viewpoint on translation and intercultural contacts. These Flemish bilinguals condemned both the unilateral selection criteria and the style of the translations for giving a one-sidedly popular, condescending, old-fashioned image of Flanders and of Flemish literature, 
confirming perceptions of the francophone nation's and literature's superiority. They argued for a more modern selection in a less popular style (M. E. 1932, Kenis 1932). Although his personal preferences went in the same direction, Roger Kervyn felt caught between two poles. When, through multiple intersections, the gap between the personal history of the translator, the collective history of his francophone public, and the collective history of the emancipating Flemish interculturals was increasing, he stopped translating. Thus, the divergent internalization of the structuring principles of the source and target literary fields and of their mutual contacts in an intercultural individual, his monolingual target public, and his multilingual source public co-determined the end of his translations of Flemish novels into French.

\section{"Sources" and "targets": are they irrelevant then?}

The question to what extent this "Belgian" history is exceptional can of course only be answered on the basis of similar projects. A reference to parallel Canadian situations seems obvious, but it cannot be made on the basis of the so-called bilingual position of both countries because this is a quite naive assumption about similarities, especially those that relate to language. Besides the number of languages in question and their exact positions, we also need to take into consideration such factors as particular neighbours and their size. It would also be naive to stick to nation-based patterns only. It is precisely the sociological component that provides functional-systemic concepts and questions with more depth: what kinds of systems/fields are at stake?

What is the translator's sociolinguistic profile in a given context? How do one's stylistic translational choices relate to a certain (intercultural) habitus? Who has the right to be a translator? Why does a translator stop translating? Answers to these and other questions depend neither exclusively on individual nor on collective factors but require an analysis of the relations between structure and agency. In cases involving multilingual contexts, actors perceive their (inter)cultural positions and develop their (inter)cultural position takings in dialogue with insti- 
tutional and discursive structures that are intimately linked with the overlapping - and sometimes competing - concepts of "language," "culture," "translation," and intercultural relationships. More fundamentally, the less geography is a distinctive feature among languages, literatures, and cultures, the more the actor's habituses play a key role in their definition and in the understanding of intercultural dynamics. Texts and discourses can cross so-called linguistic and cultural boundaries, shaking up the analytical pertinence of a clear-cut distinction between "sources" and "targets." Translated texts not only function in the "target" culture but also remain a tangible reality within the "source" culture. Does this imply then that these fundamental concepts become irrelevant for translation studies? On the contrary: "it's also in the mind." In the numerous past and present contexts in which the ideal Western nation-state's one-to-one relationship among territory, language, literature and people has been blurred, "sources," "targets," and their relationships survive with all the more pertinence through the actors' (inter)cultural habitus. We therefore need to redefine the key concepts "source" and "target" cultures, texts, discourses, and so forth - as a matter of perception, too, since it is a function of the internalization of the institutional and discursive structures by the (inter)cultural agents through their variable and varying positions and position takings in both the "source" and "target" cultures. So we need very flexible definitions: which "sources" and "targets," for whom, when, where? Definitions for which we have to integrate the concept of agency into communication-oriented models.

REINE MEYLAERTS

KULeuven

(Belgium) 


\section{Notes}

1. Similarly, actor-oriented paradigms have to take into account the conditions and conventions of communication analysis.

2. Until now, field theory, conceptualizing national literary functioning from a sociological point of view, placed hardly any focus on the study of intercultural relations. The first issue of Actes de la Recherche en Sciences Sociales to be devoted to literary translation appeared no earlier than September 2002. See also Boyden and Meylaerts, 2004.

3. Although it might at first sight appear to be a reduction, "literature" and "translated literature" deserve to be rediscovered precisely from the institutional perspective, since literature is generally much more than "just literature": it is one of the symbolic values, as much as sports or business can be in our contemporary world (Anderson 1991, Bourdieu 1992).

4. Numerous political histories give a detailed historical and political account of the language question (for example, see Luykx 1985, Witte 1990). Von Busekist (1998) analyzes the relations between language policy and nationstate construction but does not deal with the fundamental role and position of translation! For recent studies on the role of translation in the dynamics of languages, literatures, and cultures in Belgium, see CETRA (2004) and Meylaerts (2004).

5. In 1914 compulsory school attendance was fixed at the age of 12 ; this was late in comparison with other neighbouring countries like the German States (1850) or France (1882).

6. Of course, the South was also multilingual (French-French dialects), but individuals' sociolinguistic and sociocultural positions and position takings there never had the conflictual character they had in the North. The gradual superposition of standard French over the various dialects took place with the kind of "minor" problems that normally occur when a series of vernaculars and a related standard language coexist. On this see, for example, Klinkenberg (1981).

7. First of all, in the beginning these laws didn't provide for any measures in case of non- observance. Furthermore, political life remained francophone for several decades; until 1962, ministers used only French in cabinet meetings. In public life, the middle and higher classes continued to speak French in the chic stores of big Flemish cities.

8. The 1920s-1930s was the only period in which French was the first target language for Flemish prose translations. For the exact numbers, see Meylaerts (2004).

9. I thank my colleague Michael Boyden for the correction of the English translations.

10. See, for example, Van Cauwelaert (1932a). 
11. The average number of translations of Flemish in French is only 1.5 volumes per translator.

12. Between 1931 and 1933 Roger Kervyn translated 5 volumes (Timmermans 1931, Claes 1931, Walschap 1931, Verhavert 1932, Claes 1933); besides that, more than ten translations were published in Belgian francophone journals.

13. The regionalist genre was at the time the most successful Flemish literary genre, with real bestsellers that everybody still knows today. For the Flemish reader these picturesque stories had an emancipating function, giving a voice to the popular characters they depicted.

\section{References \\ Primary sources}

\section{A. MANUSCRIPTS}

Archives et Musée de la Littérature, Bibliothèque Royale Albertine, Brussels: Correspondence to Roger Kervyn de Marcke ten Driessche, ML 4331. Correspondence of Roger Keryvn de Marcke ten Driessche, ML 3858.

Archief en Museum voor het Vlaams Cultuurleven, Antwerp: Correspondence of André De Ridder, R462.

\section{B. PUBLISHED SOURCES}

Claes, Ernest. (1931). Le Réveillon du Gueux. Wannes Raps, trans. Roger Kervyn de Marcke ten Driessche. Louvain: Editions Rex.

Claes, Ernest. (1933). Kiki, trans. Roger Kervyn de Marcke ten Driessche. Bruxelles-Paris: Durendal-Lethielleux.

Gilkin, Iwan. (1924). "Chronique littéraire." Revue Belge (1/3/1924), 491-500.

Kenis, Paul. (1932). "Lettres néerlandaises." Le Rouge et le Noir (6/7/1932), 4.

Kervyn de Marcke ten Driessche, Roger. (1923). Les Fables de Pitje Scbramouille. Bruxelles: La Jeunesse Nouvelle.

Kervyn de Marcke ten Driessche, Roger. (1934). Déboulonnage. Bruxelles: Rond-Point.

Kervyn de Marcke ten Driessche, Roger. (1954). Le balancier des routines. Bruxelles: Rond-Point.

Maes, Pierre. (1932). "Portraits d'écrivains. Cyriel Buysse." Revue Belge (15/8/1932), 311-317.

M. E. (1932). "Lettres néerlandaises. Première série des chefs-d'oeuvre flamands. Aux éditions 'Rex.' Louvain." Le Rouge et le Noir (22/6/1932). 
Timmermans, Felix. (1931). Les très belles beures de Mademoiselle Symphorose, béguine, trans. Roger Kervyn de Marcke ten Driessche. Louvain: Rex.

Van Cauwelaert, August. (1932a). "Boekbespreking." Dietsche Warande en Belfort (6/1932), 496.

Van Cauwelaert, August. (1932b). "Mathias. Trans. Roger Kervyn de Marcke ten Driessche." Revue Belge (15/6/1932), 481-490.

Van Den Oever, Karel. (1908). "Kritisch Proza. Les Lettres flamandes d'aujourd'hui." Vlaamsche Arbeid, 515.

Verhavert, Cypriaan. (1932). Types bruxellois, trans. Roger Kervyn de Marcke ten Driessche. Louvain: Rex.

Wullus-Rudiger, Armand. (1929). "Le conflit linguistique et sa solution." Revue Belge (1/7/1929), 1-28.

\section{Secondary sources}

Actes de la recherche en sciences sociales, 144. (2002). (9/2002).

Anderson, Benedict. (1991). Imagined Communities. London-New York: Verso.

Bourdieu, Pierre. (1971). "Le marché des biens symboliques." L'année sociologique, 22, 49-126.

. (1991). "Le Champ littéraire." Actes de la recherche en sciences sociales, 89, $3-46$.

(1992). Les Règles de l'art. Genèse et structure du champ littéraire. Paris: Seuil.

Boyden, Michael, and Reine Meylaerts. (2004). Target: International Journal of Translation Studies, 16:2, 363-368.

CETRA [Lambert, José]. (2004). "La traduction littéraire comme problème belge ou la littérature comme traduction." In Littératures en Belgique / Literaturen in België. Diversités culturelles et dynamiques littéraires / Culturele diversiteit en literaire dynamiek, ed. Dirk De Geest and Reine Meylaerts. Brussels: PIE-Peter Lang, 105-136.

Corcuff, Philippe. (2003). Bourdieu autrement. Fragilités d'une sociologie de combat. Paris: Discorde.

Fokkema, Douwe. (1997). "The Systems-Theoretical Perspective in Literary Studies: Arguments for a Problem-Oriented Approach." Canadian Review of Comparative Literature, 24:1, 177-185.

Geldof, Koenraad. (1997). "Du champ (littéraire). Ambiguïtés d'une manière de faire sociologique." Canadian Review of Comparative Literature, 24:1, 77-89.

Hermans, Theo. (1995). "Toury's Empiricism Version One." The Translator, 1:2, 215-223.

Klinkenberg, Jean-Marie. (1981). "La production littéraire en Belgique francophone: Esquisse d'une sociologie historique." Littérature, 44, 33-50.

Lahire, Bernard, ed. (2001). Le travail sociologique de Pierre Bourdieu: Dettes et critiques. 
Paris: Découverte.

Lambert, José. (1991). "In Quest of Literary World Maps." In Interculturality and the Historical Study of Literary Translations, ed. Harald Kittel and A. P. Frank. Berlin: Erich Schmidt, 133-143.

. (1996). "Language and Translation as Management Problems: A New Task for Education." In Teaching Translation and Interpreting 3, ed. Cay Dollerup and Vibeke Appel. Amsterdam and Philadelphia: John Benjamins, 271-293.

Luykx, Theo and Mark Platel. (1985). Politieke geschiedenis van België. Antwerpen: Kluwer.

Meylaerts, Reine. (1999). "Lecture." Les Fables de Pitje Scbramonille by Roger Kervynvde Marcke ten Driessche. Bruxelles: Labor, 113-137.

- (2004). L'Aventure flamande de la Revue Belge: langues, littératures et cultures dans l'entre-deux-guerres. Bruxelles: PIE-Peter Lang-Archives et Musée de la Littérature.

Sheffy, Rakefet. (1997). "Models and Habituses: Problems In the Idea of Cultural Repertoires." Canadian Review of Comparative Literature, 24:1, 35-47.

Simeoni, Daniel. (1998). "The Pivotal Status of the Translator's Habitus." Target, 10:1, 1-39.

Von Busekist, Astrid. (1998). La Belgique. Politique des langues et construction de l'Etat. Bruxelles: Duculot.

Witte, Els, et. al. (1990). Politieke geschiedenis van België van 1830 tot beden. Antwerpen: Standaard Uitgeverij. 
This page intentionally left blank 


\section{Microhistory of Translation}

T he problem of historical awareness in research concerned with translation is - this is my main assumption — an issue which still deserves a great deal of reflection and investigation. I believe that the challenges posed by historical paradigms and historiographic models can open the study of translation to the dimension of the past with the whole deep, intricate and problematic nexus of questions it brings along with it. In the considerations that follow I would like to take up some of these questions with reference to clues offered by a particular paradigm, that of microhistory, and interrelate them with the claims and the issues at stake in translation history.

Since the mid-1970s, microhistory has proposed that historical research seek out and define different, diverse - possibly new - historical subjects, such as the circumscribed phenomena of human agency maintained in sharp focus against the abstractions of sociologically or institutionally inspired history. ${ }^{1}$ Microhistorians have privileged the study of marginal individual cases in their "normal exceptional"2 
transgressions of what is commonly described as the mainstream continuity in the understanding of the past. To this end, researchers have drawn attention to documents and archives previously neglected or read with purposes different from those that, for instance, allowed historian Carlo Ginzburg to bring to light the "cosmos of a Sixteenth century miller" (the title of one of his most famous "microhistorical" accounts [1976]). In line with the general debate about history, this movement has stimulated not only a rethinking of issues regarding sources and archives, but also a redefinition of the relationship with the past as a fragmentary dialogue, and an awareness of the narrative nature of history in relation to the subjective position of the historian.

How can these issues concern translation history? As a preliminary step to answering this question, I believe that some remarks on the role of historical awareness in translation history are needed.

\section{Historical awareness}

Translation history is at a point where history in general, after the optimistic approaches of the so-called Nouvelle Histoire, is faced with doubts and questions: the loss of trust in certainty and quantification, the abandonment of traditional periodizations of historical topics, or the questioning of categories (social classes, professional classifications) or strong interpretative models (Marxist, structuralist, or whatever). Yet history is still there. There has, of course, been Foucault's (1969) dismissal of "history" in favour of an "archaeology" of knowledge; but the constant of his thought, though it underwent several transformations during his lifetime, can be found in an attempt to historicize the great abstractions and reformulate them in the realm of social and historical constructions. And there has also been the deconstructionist dismissal of the metaphysical subject, but this, perhaps paradoxically, has opened the possibility of identifying new, different players that acted in the past and were not recognized as such. The post-structuralist approach found its radical epilogue in statements and perspectives which have changed the way history looks at itself. For instance, we have Richard Rorty's 
(1991) claim that truth, and above all any supposed historical truth, is entirely dependent on context, and thus a historian should never impose her own truth upon another's. Or Hayden White's awareness of what he has called "the content of the form" (1987), the positivistic narrative models that trap the writing of history within the linearity of accounts which present the world as a coherency, on its way from a "beginning" to an "end."

Taking into account all these problems, even "au bord de la falaise" (on the brink of ruin) as Roger Chartier (1998), after Michel de Certeau, described the present condition of historical research, historians have put forward an understanding of historical truth and objectivity which admits that it is impossible for any research to be neutral and accepts the fact that seeking knowledge involves a struggle among diverse, even material, factors. For example, Dominick LaCapra in 1985 brought forward this list of related concerns central to historiography:

The complex nature of history as a dialogical exchange both with the past and with others inquiring into it ${ }_{i}$ the role of critical theory in historical understanding, the relation of historiography to other disciplines; and the need for historians to respond creatively to newer challenges in contemporary thought. (LaCapra 1985, 9)

Not that what I proposed to consider as the problem of historical awareness has not been taken into account in relation to translation history. Since the 1990s in translation studies there has been, on the one hand, a significant increase in research that explicitly defines itself as "history of translation," and, on the other, various attempts at establishing a specific methodological frame capable of pointing out possible future developments as well as current failures and deficiencies. In particular, scholars involved in descriptive translation studies have repeatedly highlighted the underdevelopment of historical reflection and historical research in the field of translation studies. For instance, in 1992 Anthony Pym wrote a "complaint concerning the lack of history in Translation histories" and in 1993 José Lambert outlined a programme of research to 
be done in relation to history, historiography and the discipline.

Lieven D'hulst (1996) focused on methodological questions in the historiography of translation, pointing out the need for historical awareness in the definition of an interdisciplinary field of study and in the understanding of origins and development of ancient and modern theories. To D'hulst, the acquisition of a truly historical dimension is related to the consideration of traditionally neglected sources and correlated disciplines, a productive interaction between contemporary and historical concepts beyond progress-oriented models, and the awareness of a "paradigm" within the field of studies. ${ }^{3}$ Together with this, D'hulst on a number of occasions underlined $(1991,1993,2001)$ the need to practice an epistemologically conscious historiography of translation theories, in order to put forward a metalinguistic understanding of the historicity of the study of translation both in the past and in the present, but also with the aim of avoiding the indirect effect of confining "the role of the historian to that of a mere subsidiary, a presenter or an illustrator" (D'hulst 1993, 83; our translation). For the historian of translation, only from a theoretically grounded reflection does the awareness of the variety of possible "methods of historiography" derive. And the next step forward from this awareness is the consideration of the "almost overwhelming" range "of possible categories of historical facts." As D'hulst states (2001,4), in translation history, "although anything in fact is a candidate, not everything is a relevant candidate a priori" to become an object of study. There is no neutral choice in this sense. As Toury writes in this regard:

Far from being a neutral procedure, establishing an object of study is necessarily a function of the theory in whose terms it is constituted, which is always geared to cater for certain needs. Its establishment and justification are therefore intimately connected with the questions one wishes to pose, the possible methods of dealing with the objects of study with an eye to those questions - and, indeed, the kind of answers which would count as admissible. (Toury 1995, 23) 
Therefore, when history is involved, different methods of historiography and historical theories relate to different objects of study. I wish now to try to reflect on what a microhistorical perspective can add to these considerations.

\section{New objects of study}

With the advent of microhistory, what came explicitly to light was a claim to novelty in history that consisted in a reduction of the scale of historical research, seen as more rewarding than the massive accumulation of repetitive evidence in order to isolate and test many abstractions of social or economic thought (Muir 1991, viii). This way individual experiences, voices lost in the past, apparently irrelevant exceptional cases took the centre of the stage. Even when microhistorians have studied great, famous men, such as Galileo Galilei, they have focused on obscure clues that have traditionally been ignored or dismissed as insignificant.

When looking at works and research that, explicitly or implicitly, claim to define themselves as histories of translation, in most cases one can find a common general concern not far removed from the microhistorical goal to discover or rediscover previously neglected subjects, alien to the grand narratives of traditional history. Even a quick survey of a number of these works provides grounds to say that they all try to highlight - albeit from different perspectives and with different specific aims - the neglect of translation's role as a cultural practice, and of translators as cultural agents, by historical investigation seeking to define a coherent and organic cultural history in which the shifts of boundaries between and within cultures are deliberately denied.

Indeed, it is in these issues and perspectives that historians of translation find prime motivation for their research. For instance, Pym (1998) advances a "hypothesis projecting intercultural belonging," on the basis of which he claims that writing a history of translation is necessary to the priorities of current intercultural stances, in order that the past may be read from the point of view of central issues of the present. Another example: Tymoczko, in Translation in a Postcolonial Context, places at the 
centre of her interest translation's role as a tool for investigating the colonization and decolonization of Irish culture. More specifically, she writes that her volume

investigates the translation of early Irish literary texts as one of the discursive practices that contributed to freeing Ireland from colonialism, a discursive practice that took its place among other discursive practices that shaped Ireland's resistance to England and led eventually to political action and physical confrontation (Tymoczko 1999, 15).

Yet already Antoine Berman had focused, within romantic culture, on the translational dimension because it was in that space that he tried to recover "une autre dimension littéraire" (Berman 1984) opposed to monologism and absolutist self-reflection, a dimension where history, ethics, and analytical practices could be linked in view of a dialogical relationship (in a sense close to the formulation of Mikhail Bakhtin). And Lawrence Venuti's reuse of Schleiermacher's theory in the binary opposition of domesticating and foreignizing translation strategies serves the agenda of denouncing the invisibility of translators in what he calls "a history of translation" (this being the subheading of his well-known 1995 book). Even more explicit in referring to the dimension of otherness is Michael Cronin in his 1996 Translating Ireland, which he describes as "a history of encounters" (Cronin 1996, 1) wherein the role of translators as creative and inventive mediators has been largely ignored in traditional reconstructions. He claims to have highlighted, through his historical approach, the necessity of considering "the presence of the other" and to have made "a case for dialogue and renewal" (Cronin 1996, 200), receptiveness, reciprocity, and so forth. All this, and we have still not mentioned those works that highlighted the role translation played in the assertion of women's awareness as oppositional to dominant ideologies (such as Krontiris 1992 or, more recently, Agorni 2002).

Therefore, generally speaking, it can be affirmed that the first commitment of translation history has been the desire to highlight the 
disrupting role translation played in cultural history, positing it as the exceptional case that goes against traditional, consolidated, but never neutral reconstructions.

These claims against traditional reconstructions have for many decades now been at stake in the general debate about history. In particular there has been an awareness of the fact that historical coherence is actually gained through marginalizing and suppressing anything not leading in a definite, teleological direction, through according privilege only to certain perspectives and subjects, and, instrumentally, through affirming or denying cultural boundaries. Traditional reconstructions were founded on the telling of a peculiar Western "story," based on a success- and progress-oriented model aimed at the neutralization of various forms of otherness and diversity.

As I said, translation in history is often presented as an alternative view, as a perspective that reveals new aspects of the past. But it is possibly in order to prove these assumptions via strong, acceptable evidence that more striking, high-profile topics of investigation have been privileged with a prominent focus on what could be called "canonized," visible topics, issues, subjects, and events. Because if we consider the paradigm that identifies a continuity between past and current translation histories we find in most of them, almost paradoxically, a particular emphasis placed on explicit theorizations, on translations purposefully justified, on the visible interventions of translators as operators, regardless of the theoretical and methodological frames they refer to. For instance, Georges Mounin, in his Teoria e storia della traduzione, accords the role of "transforming translation into a concrete activity" only to Roman "systematic thought on the art and the craft of translating" (Mounin 1965; our translation). Hence, no translation before written theory. And this is especially true for Steiner's After Babel, purposefully directed towards establishing a canonized great tradition (in a strictly highbrow-Western-male sense) in translation history (Steiner 1975); or for Edmond Cary's Grands traducteurs français, whose very title is a declaration of intent (Cary 1963). But one may also think of Antoine Berman's insightful rereading of German translation theories 
in the romantic period, where the main focus is on theoretical declarations by established intellectuals (Berman 1984); or, in the 1990s, of the various collections and anthologies of Western translation theories (from Robinson 1997 to Venuti 2000, for example), of translation theory in France from 1748 to 1847 (D'hulst 1990) and so on; or of the account in Translators through History, edited by Delisle and Woodsworth, that singles out the most significant episodes, meaning also the most visible.

From these different points of view some issues may remain marginalized: among others, translation strategies and practices that in the past were widely accepted but never theoretically systematized, translators' experiences carried on in the context of a generally underrated intellectual activity, interactions between production, circulation, and use of translations, and many other aspects of the discipline that could become objects of study in microhistorical terms. The key to this possibility — this is what I will try to discuss later on — is strictly linked to a dynamic and never problem-free questioning of the past.

\section{In dialogue with the past}

In fact, it was as a result of my research on eighteenth-century translations of novels in a cultural area defined as Italian that these questions came to my attention. That research aimed to describe and highlight the role of translation in the context of the rise and the inferior status of the modern novel as a genre in the eighteenth century, in relation to the formation of new audiences as well as new reading practices. The process of this formation was linked to a change in the rates of scholarship and literacy and to the growth of the publishing market. I argued that translations were addressed to a lower-middle standard of enlarged public (to the extent that we can label the eighteenth-century reading public as "low" or "wide") constituted mostly by women; they were an important factor for the definition of a female reading public which had not been considered as a separate entity before (Adamo 2001). It is in this regard that the function of translation had to be delineated through the analysis of different kinds of documentation: not only textual and 
paratextual elements in the translations, but also the translators' own statements contained in prefaces and dedications, in their letters and memoirs, or in publishing data (when available).

Especially at the stages of corpus definition, collection of materials, and problem focusing, many facts came to light that failed to fit into any of the possible existing models. For instance, it was evident not only that many translations of my corpus-in-progress didn't define themselves as such - they were "hidden" translations just as the identity of the translators was in its turn often hidden behind a veil of anonymity or pseudonymity - but also that these translations seemed not to acknowledge the dictates of contemporary written, formalized theories, those that have been transmitted and canonized. It was not just a matter of "translators' (or translations') invisibility," as Venuti puts it, but of problematic, hardly identifiable, visibility. For instance, there was an intense theorizing about translation throughout the period I was taking into account, but explicit theory referred mainly to translation from the classical languages, Greek and Latin (Mari 1995; Gensini 1989), whereas nothing corresponded to the actual translation practices I was observing in the translated novels of my corpus. The widespread practice of translation or retranslation of novels (a new, not canonized, but increasingly more significant genre) from French into Italian had no previous grounds to refer to. It was a practice deeply rooted in the needs of the publishing market and in the demands of the active and creative cultural consumption of the readers. What I wanted to recover was the variety and the complexity of the translation practices far beyond established theories and norms. ${ }^{4}$ Problems included the translators' differing representations, their different ways of manifesting their presence and agency, ${ }^{5}$ and the challenge of grasping the traces of women readers in that setting.

All the necessary clues were hidden in the "normal exceptional" obscurity of the past. And the very idea of the obscurity I was dealing with came to me from the past. This is how a translator made her/his presence felt: 
If the translation is not perfect ..., readers, please, don't be surprised. Someone who was born, was brought up, and grew up in obscurity can't distinguish her/himself too much. (Benoiste 1771)

The focus on the problems set by the choice of the object of study is linked to a condition of historical work that, while it may imply naïveté, is nevertheless undeniable: the historian's most distinctive problem is that posed by temporality itself. In microhistory, for example, new and alternative objects of studies clearly represent just fragments of the past and never aspire to grasp its totality. But actually, they offer an alternative method for the evaluation of historical evidence through what Carlo Ginzburg has called the conjectural paradigm - that is, an apparently systematic way to sort out fragmentary clues through abduction (Ginzburg 2000 [1979]). This use of minority approaches that call for interdisciplinary methodologies avoids the dangers of constructing grand narratives a priori. The past remains undeniably other, something virtually unknowable with which the historian can only negotiate her investigations in order to have a glimpse of what Natalie Zemon Davis (1981) has called "the social creativity of the so-called inarticulate."

The questioning of the past in these terms is not an issue taken for granted in translation history. In 1993 Paul St-Pierre recognized that the relation between history and translation can be considered in two different ways: on the one hand, one can interrogate this relation in order to get a better knowledge of the origins of translation; on the other, the intertwining of these two elements can lead to the definition of the contexts in which translation practices take place and of the influence the contexts exert on the practices (St-Pierre 1993, 9). From this differentiation St-Pierre has drawn the consideration that, of these two different approaches, only the former actually has something to do with the awareness of the past as such, since "l'importance du contexte en traduction peut être démontrée par une étude strictement synchronique" (the importance of context in translation can be demonstrated by a strictly synchronic study; St-Pierre 1993, 9; our translation). And if we 
move from theory to practice, taking as an example Pym's Negotiating the Frontier, we can see that, actually, this relation becomes virtually problem free. First of all, Pym declares that his study of single cases is transparently linked to the possibility of addressing "issues of a more general nature beyond the concerns of local colour and narrow historical representations" (Pym 2000, 1). Then he admits that the real purpose of his investigation is not the past but the present question of "how cultures should interrelate," and history has the only instrumental role in helping to answer that question. The paradigm of investigation adopted by Pym not only deliberately avoids taking into account the problem of what can be described as anachronism but also explicitly configures an effacement of the dimension of otherness of the past.

The assumption in microhistory is that the past is utterly alien to the present and it is not just there ready to answer our questions, as Pym states. According to Ginzburg, (as explained by Muir 1991, xii), for example,

the proper goal of the historian is not to explore the historical implications of a contemporary theory or problem, but to write about things that are totally forgotten and completely irrelevant to the present, to produce a history that is 'really dead.'

Naturally, this is a rather utopian goal and it has been very much criticized both by those who still try to elaborate a strong, totalizing model for the knowledge of the past and by those who believe that history is nothing but narrative representation. However, even a critic of Ginzburg such as Dominick LaCapra ${ }^{6}$ has warned that "the past is not an 'it' in the sense of an objectified entity that may either be neutrally represented in and for itself or projectively reprocessed in terms of our narrowly 'presentist' interest" (LaCapra 1987, 10).

In this sense the model of microhistorical analysis is particularly challenging also for the history of translation, because it helps to highlight some naive beliefs in the possibility of a transparent instrumental history and offers a dialogic hermeneutic dimension from where to start 
asking new questions without overstating or idealizing the notion of dialogue itself. In fact, the dialogue does not take place with the past itself but with material remains that need to be interrogated as evidence in order to produce what is considered historical knowledge.

\section{Sources and archives}

Naturally, it is the historian's questioning that turns the material remains from the past into evidence, for evidence is only evidence in relation to a particular account. But is there any influence of the past on the historian involved in these operations? As Joyce Appleby and others have observed, for the historian any kind of knowledge depends on the attempt to figure out the past (Appleby et al. 1994). Records are left by people who themselves lived in that past. Yet the records are extant in the present. The past as a series of events is gone. What stay on visibly in the present are the physical traces of past living, the materials or objects that historians turn into evidence when they begin asking questions. Accordingly, how much and in what ways do the material remains of the past affect the researcher whose principal task is to reconstruct, interpret, and preserve artefacts from the past?

I believe that translation history is deeply concerned with these issues since the generalized marginality of translation practices has prevented records from being linked in the present in a systematized, recognizable way. Catalogues, archives, libraries dedicated to translation are rare if they exist at all, records of translators' experiences have not often been conserved and passed on. Translators are only in a few cases easily identifiable individuals whose experiences left clear records that we still have access to; consequently, the records sometimes have to be searched for elsewhere than in traditional sources and recognized archives.

The dominating practices of the past, along with their present reproduction, may still be operating an effacement of more silent experiences and subjects. Sources in translation history are often the result of a process of negotiation between the fundamental intention with 
which documents were conserved and the struggle to establish a dialogue with what fell out of that intention. Questions of selectivity and the significance of documents are always at stake when dealing with an object of study such as "translation," which actually tends to be erratic, heterogeneous, and idiosyncratic, and thus constantly questions the definitions attributed to it. Instead of aspiring to objective documentary reconstructions which look for "facts" about some "reality" in an acritically conceived past and emphasize coherence and continuity, we can take another approach. The more fundamentally sound effort might be to recover the many silenced voices of translation without imposing an overly strict interpretive model that would efface their complexity and richness.

Recovering the voice of marginal subjects on the grounds of fragmented and apparently minor data was not only the first commitment of microhistory but was also very present to Michel Foucault when he, for example, devoted himself to the study of "la vie des hommes infâmes" (the lives of infamous men; Foucault 2001). Microhistorians evinced the same fascination and involvement as Foucault, also in an emotional sense, with the exceptional liveliness and transgressive energy that emanated from obscure lives whose traces remained trapped in the archives. And both wanted to see there a subversive potential for confronting power. But if Ginzburg, for example, conceded the employment of philological evidence (albeit in unconventional ways) in order to use archival documents in the writing of history, Foucault was very critical of verification standards deriving from a modern scientific discourse that refamiliarizes the past so it conforms to the terms of the present. He was looking for an accurate way of resorting to archives which does not essentialize, but considers them critically, and starts at points where the documents are more problematic, opaque, and alien as the only way to let lost voices speak for themselves. ${ }^{7}$

On these premises, Arlette Farge has stated that the historian should try to find the right place in her writing for quotations, words drawn from the past that in historical writing could represent the presence of a difference, of a real gap (Farge 1989). It is probably not the same to tell 
the story of an obscure translator from the point of view of the ego of the historian or from a seemingly neutral third-person account as it is to discover even a very small corpus of her own statements and bring it to light, putting it in the context of the writing of history.

Indeed, the writing of history is the product of different choices and aims. It is never just a neutral account, but a narrative aimed at producing knowledge of the past, a form which belongs, after all, to the realm of storytelling.

\section{The content of the form}

As theorists such as Michel de Certeau and Paul Ricoeur explained, the work of historians produces texts that can be analyzed as such. Historical accounts and fictional narrations share the same ways of representing their characters, the same way of constructing their temporality, the same models of causality (Certeau 1975, Ricoeur 1983). From a more radical perspective, as that of Hayden White, for example, history can even be seen as merely a narrative fiction written for teleological, self-interested purposes. ${ }^{8}$ I do not want to suggest that one has no choice but to share these assertions, but I think that the question from where they stemmed is still not a minor one. "What does it mean to think historically, and what are the unique characteristics of a specifically historic method of inquiry?" asked White at the beginning of his Metabistory (White 1973, 1). And this led him to analyze the different narrative and rhetorical forms that the fictional character of historical reconstructions can assume.

If the same kind of analysis is applied to existing histories of translation one can detect an extremely differentiated and variegated approach to these issues. On the one hand we have, for example, Pym, who believes that translation history is concerned mainly with translators, points toward awareness of the form, and puts forward what can be seen as a kind of autobiographical writing able to bring to light the experiences of people as characters he meets. Yet there are also collective anonymous accounts such as those in Delisle and Woodsworth's Translators througb History, or the narrations of a character involved in a 
plot pointing to a definite end, found in Maria Tymoczko's book. And also translation histories that openly rely on master narratives, with a third-person narrator who objectifies aims and motivations such as the legitimacy of a minority language (Corbett 1999), the affirmation of a national unified tradition (Ruiz Casanova 2000) or the reasons for a theory (namely Skopos theory in the case of Vermeer 1992). Different narrative devices for different aims. Yet the awareness of these devices has been only vaguely postulated in translation history. This is, for example, how Pym dismisses the problem: "Indeed one could probably just tell the stories and trust their entertainment value to carry all else. Yet amusement is not our sole purpose here" (Pym 2000, 1).

As far as I know, no specific reflection or good exemplification of alternatives that can shed light on the heterogeneity of translation as a subject has been proposed. But if one looks again at the model that has been considered here, one can see that among the microhistorians it was Ginzburg in particular that offered a striking exemplification of how narrative and history can melt together in a theoretically grounded way able to establish an interrelation between the object, the motivation, and the result of the research. In his Il formaggio e $i$ vermi he proposed a consciously constructed narration which makes the reader participate in the difficulties of the research, of the shifting conjectures conducted by the historian upon fragmentary clues and aimed at catching otherness in the past. ${ }^{9}$ This way the goal of the historian and all the complexity of his theoretical frame finds an ideal concretization in writing.

\section{Conclusion}

To conclude, I would like to raise a question about the possibility of elaborating on similar issues in translation history on the grounds of an awareness of all the complex nexus of problems the simple word "history" brings. In such a landscape, where history is mainly concerned with doubts and questions, is there any space for a history of translation? Are there any grounds for writing this history if the constitutive 
hybridity or interculturality of translation may lose its disruptive potential when involved in the tricks of master narratives and "master" objects of study? The definition of the object of study in terms of novelty, fragmentariness and transgression; the acknowledgement of the potential otherness of the past not reduced to an instrumental tool for inquiring into the present ${ }_{\text {; }}$ the consideration of the highly problematic status of sources and archives; and the theoretical as well as practical consciousness of the narrative dimension of historical writing are all challenges and hints that microhistory can pose to the history of translation. Taking them into account could mean working in a field of study open to diverse, stimulating questioning, where microhistory is only one of the many models and issues at stake.

SERGIA ADAMO

University of Trieste

(Italy)

\section{Notes}

1. All those who have written on microhistory agree that the most distinctive and unifying element in all research that recognizes itself as microhistorical can be identified in the reduction of scale, from which all other aspects derive. See, for instance, Levi (1991), Muir (1991), Grendi (1994), and Revel (1994). See also Ginzburg and Poni (1979) for the stress put on individual cases.

2. The oxymoronic phrase "normal exceptional" was proposed by Grendi (1977) as an indication of what microhistory should seek.

3. I am referring here to Thomas Kuhn's well-known notion of "paradigm" as an intersubjective agreement, as the product of consensus within a group or a set of shared understandings that dictates what research is important and what problems need to be solved in a given discipline at a given moment (Kuhn 1970 [1962]).

4. "Augmented work," "drawn from French," "brought from French," "arbitrary translation," "improved edition" - these were only some examples of the multifarious ways translation was referred to. Moreover, some works were defined only as "edited by" or "compiled by," and when the first source text was in English, I also found it designated as "imitated from English by" plus 
the name of the French translator or even as a "work written in English, then translated into French, and now transported from French into Italian" (such as in La Place n.d.).

5. For instance, in many cases the translator's name was not indicated or the real name was hidden behind a pseudonym. In others, there were additional indications about the translator. For example, one novel was described as a "Gallant story drawn into Italian from French by Dr. Giulio Monti, churchman from Bologna" (Lesage 1728); in another case more emphasis was laid on the name and the status of the last translator than on other people who, in different ways, had made their contribution to the text: "Work brought from Spanish into French by Mr. N. N. and from French into Italian by Abbé Nicola Felletti" (Lesage 1714); or in some cases the gender and the class of the translator were clearly specified, such as in "Novella translated into French by a noble Lady" (Anonymous n.d.).

6. See LaCapra (1985), 45-69, for instance.

7. A different attempt to apply Foucault's thought to the consideration of translation in history is St-Pierre (1993a). Here St-Pierre applied Foucault's argument for an archaeology of knowledge to the study of translation as a discursive practice and outlined a specific program, taking into account the limits of forms of the translatable and of conservation, memory, reactivation, and appropriation in relation to translation in social and historical contexts. (St-Pierre 1993a, 61-68).

8. Discussions of history and narrative have become more common in the last decades (see Roberts 2001), but — as Stone (1979) has explained — they are not only characteristic of our contemporary times.

9. The importance of narration and storytelling in his historical writing has been especially underlined in Ginzburg (1994). For an analysis of the characteristics of Ginzburg's writing see Serna and Pons (2000).

\section{References}

Adamo, Sergia. (2001). "Übersetzungsgeschichte als Geschichte der Frauen. Überlegungen zur Rolle der Frauen als Leserinnen und Übersetzerinnen im 18. Jahrhundert." In Übersetzung aus aller Frauen Länder. Beiträge zu Theorie und Praxis weiblicher Realität in der Translation, eds. Michaela Wolf and Sabine Messner. Graz: Leykam, 77-90.

Agorni, Mirella. (2002). Translating Italy for the Eigbteentb Century. Women, Translation and Travel Writing 1739-1797. Manchester: St. Jerome.

Anonymous. (N.d.). Il rivale generoso. N.p. 
Appleby, Joyce, Lynn Hunt, and Margaret Jacob. (1994). Telling the Truth about History. New York and London: W. W. Norton.

Benoiste, Françoise. (1771). Celianna ovvero gli amanti sedotti dalle loro virtù. Venezia: Zorzi.

Berman, Antoine. (1984). L'Épreuve de l'étranger. Culture et traduction dans l'Allemagne romantique. Paris: Gallimard.

Cary, Edmond. (1963). Grands Traducteurs français. Genève: Georg.

Certeau, Michel de. (1975). L'Écriture de l'bistoire. Paris: Gallimard.

Chartier, Roger. (1998). Au Bord de la falaise. L'bistorie entre certitudes et inquiétude. Paris: Albin Michel.

Corbett, John. (1999). Written in the Language of the Scottish Nation. A History of Literary Translation into Scots. Clevendon: Multilingual Matters.

Cronin, Michael. (1996). Translating Ireland: Translation, Languages, Cultures. Cork: Cork University Press.

Davis, Natalie Zemon. (1981). "The Possibilities of the Past" The Journal of Interdisciplinary History, 12, 267-275.

Delisle, Jean, and Judith Woodsworth, eds. (1995). Translators through History. Amsterdam and Philadelphia: John Benjamins.

D'hulst, Lieven. (1990). Cent ans de théorie française de la traduction: de Batteaux à Littré (1748-1847). Lille: Presses Universitaires de Lille.

. (1991). "Pourquoi et comment écrire l'Histoire des théories de la traduction?" In Actes du XIIe Congrès mondial de la FIT. Beograd: Prevodilac, 57-62.

. (1993). "Observations sur l'expression figurée en traductologie française (XVIIIe-XIXe siècles)." In L'Histoire en Traduction, ed. Paul St-Pierre. TTR, 6:1, 83-111.

. (1996). "Pour une Historiographie des théories de la traduction: questions de méthode." TTR, 8:1, 13-33.

- (2001). "Why and How to Write Translation Histories?" In Emerging Views on Translation History in Brazil, ed, John Milton. CROP 6, 21-32.

Farge, Arlette. (1989). Le Gôut de l'archive. Paris: Seuil.

Foucault, Michel. (1969). L'Archéologie du savoir. Paris: Gallimard.

. (2001) [1977]. "La Vie des hommes infâmes." In Dits et écrits, 1976-1988, ed. Daniel Defert, François Ewald, and Jacques Lagrange. Paris: Gallimard.

Gensini, Stefano, ed. (1989). Il genio delle lingue. Le traduzioni nel Settecento in area franco-italiana. Roma: Istituto dell'Enciclopedia italiana, 237-253.

Ginzburg, Carlo. (1976). Il formaggio e i vermi. Il cosmo di un mugnaio del Cinquecento. Torino: Einaudi.

. (2000). [1979]. "Spie. Radici di un paradigma indiziario." In Miti emblemi spie. Morfologia e storia. Torino: Einaudi, 158-209.

_. (1994). "Microstoria: due o tre cose che so di lei." Quaderni storici, 39:86, 511-539. 
Ginzburg, Carlo, and Carlo Poni. (1979). "Il nome e il come: scambio e mercato storiografico." Quaderni storici, 15:40, 181-190.

Grendi, Edoardo. (1977). "Micro-analisi e storia sociale." Quaderni storici, 12:35, $506-520$.

. (1994). "Ripensare la microstoria." Quaderni storici, 39:86, 539-549.

Krontiris, Tina. (1992). Oppositional Voices. Women as Writers and Translators of Literature in the English Renaissance. London and New York: Routledge.

Kuhn, Thomas. (1970) [1962]. The Structure of Scientific Revolutions. Chicago: University of Chicago Press.

LaCapra, Dominick. (1985). History and Criticism. Ithaca and London: Cornell University Press.

\section{University Press.}

Lambert, José. (1993). "History, Historiography and the Discipline: A Programme" In Translation and Knowledge: SSOTT IV (Scandinavian Symposium on Translation Theory, Turku, 4-6.6.1992), eds. Yves Gambier and Jorma Tommola. Turku: University of Turku - Centre for Translation and Interpreting, 3-25.

La Place, Pierre Antoine de. (N.d.). Storia di Tom Jones, ovvero il Bambino Ritrovato. N.p.

Lesage, Alain-René. (1714). Il diavolo zoppo. Venezia: Recurti.

- (1728). Gil-Blas di Santillano. Venezia: Bortoli.

Levi, Giovanni. (2001). "On Microhistory." In New Perspectives on Historical Writing, ed. Peter Burke. Cambridge: Polity, 97-119.

Mari, Michele. (1994). Momenti della traduzione fra Settecento e Ottocento. Milano: Instituto di Propaganda Libraria.

Mounin, Georges. (1965). Teoria e storia della traduzione. Torino: Einaudi.

Muir, Edward. (1991). "Introduction: Observing Trifles." In Microbistory and the Lost Peoples of Europe: Selections from Quaderni Storici, eds. Edwin Muir and Guido Ruggiero. Baltimore and London: Johns Hopkins University Press, vii-Xxviii.

Pym, Anthony. (1992). "Complaint Concerning the Lack of History in Translation Histories." Livius. Revista de Estudios de Traducción, 1, 1-11. - (1998). Method in Translation History. Manchester: St. Jerome.

. (2000). Negotiating the Frontier. Translators and Intercultures in Hispanic History. Manchester: St. Jerome.

Revel, Jacques. (1994). "Microanalisi e costruzione del sociale." Quaderni storici, 39:86, 549-575.

Ricoeur, Paul. (1983). Temps et récit. Vol. I: L'Intrigue et le récit bistorique. Paris: Seuil. Roberts, Geoffrey, ed. (2001). The History and Narrative Reader. London and New York: Routledge. 
Robinson, Douglas, ed. (1997). Western Translation Theory from Herodotus to Nietzsche. Manchester: St. Jerome.

Rorty, Richard. (1991). Contingency, Irony and Solidarity. Cambridge: Cambridge University Press.

Ruiz Casanova, José Francisco. (2000). Aproximación a una bistoria de la traducción en España. Madrid: Cátedra.

Serna, Justo, and Anaclet Pons. (2000). Cómo se escribe la microbistoria. Ensayo sobre Carlo Ginzburg. Madrid: Cátedra.

St-Pierre, Paul. (1993). "Présentation. L'Histoire en traduction." In L'Histoire en Traduction, ed. Paul St-Pierre. TTR, 6:1, 9-14.

(1993a). "Translation as a Discourse of History." In L'Histoire en Traduction, ed. Paul St-Pierre. TTR, 6:1, 61-82.

Steiner, George. (1975). After Babel. Aspects of Language and Translation. London and New York: Oxford University Press.

Stone, Lawrence. (1979). "The Revival of Narrative: Reflections on a New Old History." Past and Present, 85, 3-24.

Toury, Gideon. (1995). Descriptive Translation Studies and Beyond. Amsterdam and Philadelphia: John Benjamins.

Tymoczko, Maria. (1999). Translation in a Postcolonial Context: Early Irish Literature in English Translation. Manchester: St. Jerome.

Venuti, Lawrence. (1995). The Translator's Invisibility: A History of Translation. New York and London: Routledge.

, ed. (2000). The Translation Studies Reader. London and New York: Routledge.

Vermeer, Hans J. (1992). Skizzen zu einer Geschichte der Translation. Frankfurt: IKO. White, Hayden. (1973). Metabistory: The Historical Imagination in Nineteenth Century Europe. Baltimore and London: The Johns Hopkins University Press. . (1987). The Content of the Form: Narrative Discourse and Historical Representation. Baltimore and London: Johns Hopkins University Press. 


\section{Perspectives on the History of Interpretation \\ Research Proposals}

E ighty-five years ago, in 1919, a lawyer from Quebec, Joseph Belleau, was recruited to participate as an interpreter in the first international conference derived from the Paris Peace Conference (even before the League of Nations began its work). This was the Washington Conference, which gave birth to the International Labor Organization (ILO). Belleau's file in the League of Nations archives in Geneva contains just a few documents. From that file and from other documents, we have gathered information about the way interpreting services were organized and provided at that Conference. This information will be published in an article, "Conference Interpreting in the First International Labor Conference (Washington, D. C. 1919)" in a forthcoming issue of META. All we know about Belleau, apart from his brief assignment to interpret in Washington, is that he ended up teaching at Laval University. But surely there are documents, maybe a photo, that could help us rebuild the life of this pioneer of conference interpreting, who gave up that still-undefined job to join the academic profession. 
This is an example of the huge gap to be filled in the history of our discipline. But our main point here is that such gleanings of information about a temporary interpreter would relate only to his story and could be useful only to rebuild his personal biography. If we wanted to make a contribution to the bistory of interpreting, then we would have to trace the ideas Belleau and other interpreters had about interpreting, their profiles, the situation and prospects of the interpreters' freelance market in the 1920s, and so on. And if we wished to translate that material into something relevant for History, then we would have to establish the framework in which Belleau's activity took place. In this sense, perhaps it would be important to say that English acquired the status of an official language in the international institutions formed after World War I, following a long period in which French held a virtual monopoly as a diplomatic language. We would also have to mention the fact that the ILO was an institution in the 1920s in which interpreting constituted an element of democratization, since up until then workers did not have a linguistic means of communication that allowed them to feel comfortable in international gatherings. We might also say that the ILO and the League of Nations gave birth to the international civil service, including the roles of translator and interpreter as we know them. And so on.

Interpreting as a trade probably goes back to the early contacts between different human groups in prehistoric times. But interpreting — and translation for that matter — has only recently become a welldefined profession in the understanding of academics, practitioners, and society in general. That explains the relative lack of research in the history of the two fields, particularly when compared with well-established disciplines such as medicine or mathematics (Woodsworth, 1996, 9). Translation and interpreting differ in one important aspect: translation deals with written texts and interpreting with oral speeches (complemented by non-verbal information). Historical research is usually associated with documents, to the extent that we define prehistory as the period from which documents — in a large sense — are not available. Voice-recording devices have existed only since the twentieth century. Therefore, tracing the history of interpreting requires using the few 
secondary sources in which some scant information about the job of interpreting and about its practitioners may generally be found. This means that those who embark upon the task of rebuilding the history of interpreting are faced with an additional challenge: that of the sources. It is very important that researchers of the history of our disciplines use the methods and the skills of the historian (Delisle 1997-98), and this observation is necessary since, in all likelihood, it will not be history scholars but rather translation and interpreting specialists who will be attracted by this field of study. In the case of interpreting, the selection of sources and, for more recent periods, the building of one's own sources through oral history techniques will be of particular importance. The fact that previous research has been carried out in a particular area should not discourage other researchers from working on the same issues. On the contrary, the use of other tools or approaches, or simply - of a different generational perspective can make significant contributions to the knowledge of the past. It is clear, for example, that the vision of the first attempts at simultaneous interpreting by consecutive interpreters was not the same as that of subsequent generations. It is also clear that new approaches, as in the field of postcolonial studies, have shed new light on the role of linguistic and cultural mediation in terms of relationships of domination over the other. One of the elements that should be pointed out in historical research in our disciplines is that an understanding of history can help professionals, trainers and trainees face the natural changes experienced in all disciplines with technological evolution and can help researchers predict how new trends will evolve. For example, the reactions of current professionals to information technologies and remote interpreting can be understood in the framework of similar reactions in the past to simultaneous interpreting devices. Preservation of the oral heritage of veterans in the profession should also be an aim. A few years ago in Monterey, California, I entitled my contribution A Past for Our Future. Perhaps we should vindicate here a future for our past. 


\section{State of affairs}

In a previous paper on this issue I reflected on the present situation with respect to conference interpreting (Baigorri-Jalón 2003). I consider that what I said there is also valid for the history of interpretation in general. That is:

1. A bandbook on the history of interpretation does not exist, and no work, no matter how general its scope may be, can claim to encompass exhaustively all periods of history and all interpreting modalities or situations.

2. In the last two decades, efforts have been made by several researchers to produce work which contributes to filling the gaps that we have in the knowledge of our past. We refer the reader to the references in this paper. The names of researchers such as David and Margareta Bowen, Jean Delisle, Julio-César Santoyo, Ingrid Kurz or Lourdes Arencibia, among others, will always be associated with important contributions to the history of our profession. That is also the case with journals such as Babel, META, the St. Jerome Quarterly, Hieronymus Complutensis, Livius, SENDEBAR, and Interpreting, among others, and with initiatives such as Georges Bastin's HISTAL.

3. In the more general publications - only very exceptionally devoted entirely to interpreting - references to interpretation and interpreters are mixed with those of translation.

4. Some brief compilations have been produced but have not been well disseminated.

5. Most of the research, at least that known by the author of this paper, deals with experiences in the West or with Western endeavours and is framed in the historical periods or landmarks of the Western tradition.

6. Most publications are brief articles on, for example, an issue, a case, or an interpreter. 


\section{Research suggestions}

In a recent publication, Jean Delisle (2003) enumerates twenty-one fields of research that have, until now, captured the attention of researchers in the history of translation (in a broad sense). Only two of them deal specifically with interpretation, but many of them might have equivalent areas of interest in interpretation. Thus I consider Delisle's paper, and also his CD-ROM on the history of translation, as excellent starting points for those who feel tempted by the study of the history of interpretation. In our paper quoted above (Baigorri-Jalón 2003), we proposed a table summarizing research proposals, presented in four columns. The first column includes possible topics for research, the second possible sources, the third methodological procedures, and the fourth difficulties the researcher might encounter. That table was by no means intended to be exhaustive, but merely indicative. Since it referred only to conference interpreting, we will present here a more complete series of proposals which may interest future researchers.

Let us point out that some of the huge job still to be done would be better served if research were carried out by teams, in constant exchange of experiences and findings with similar groups elsewhere. In this regard, once again Delisle had a pioneering idea when he conceived the Repertoire of Historians of Translation. Research should be carried out above all at the doctoral or postdoctoral level. A proposal we make is to promote doctoral seminars on specific topics in the history of translation and interpreting, for instance through doctoral mobility programs aimed at professors, young doctoral graduates, and $\mathrm{Ph}$.D. students.

When we refer in the table below to compilations of texts, we propose the use of information technologies (IT), although printed versions should not be excluded. When we refer to documents, the word should be understood in a wide sense, including not just written records, but also photographs, sound archives, visual materials, and so forth 


\begin{tabular}{|c|c|c|c|}
\hline $\begin{array}{l}\text { TOPICS } \\
\text { Compilation of basic } \\
\text { texts on the history of } \\
\text { interpretation }\end{array}$ & $\begin{array}{l}\text { SOURCES } \\
\text { Archives, chronicles, } \\
\text { history books, institu- } \\
\text { tions, users and } \\
\text { observers of interpre- } \\
\text { tation, the media, } \\
\text { interpreters }\end{array}$ & $\begin{array}{l}\text { METHODS } \\
\text { Search, selection and } \\
\text { compilation of texts in } \\
\text { electronic and other } \\
\text { media }\end{array}$ & $\begin{array}{l}\text { DIFFICULTIES } \\
\text { Need for a historical } \\
\text { guiding thread; } \\
\text { fragmentary and } \\
\text { scattered nature of } \\
\text { sources }\end{array}$ \\
\hline $\begin{array}{l}\text { Encyclopaedia or biog- } \\
\text { raphical anthology of } \\
\text { interpreters who have } \\
\text { played an important } \\
\text { role in the profession }\end{array}$ & $\begin{array}{l}\text { Chronicles, memoirs, } \\
\text { personal archives, } \\
\text { interviews with inter- } \\
\text { preters, their relatives } \\
\text { or acquaintances, } \\
\text { works by interpreters, } \\
\text { the media }\end{array}$ & $\begin{array}{l}\text { Search of published } \\
\text { information, study of } \\
\text { unpublished docu- } \\
\text { ments, oral history }\end{array}$ & $\begin{array}{l}\text { Selection of the Who's } \\
\text { Who, access to unpub- } \\
\text { lished documents (e.g., } \\
\text { personal archives), } \\
\text { access to interpreters } \\
\text { or others for inter- } \\
\text { views }\end{array}$ \\
\hline Compilation of corpora & $\begin{array}{l}\text { Written, graphic, oral } \\
\text { (archives, verbatim } \\
\text { records or minutes, the } \\
\text { media, interpreters } \\
\text { themselves, etc.) }\end{array}$ & $\begin{array}{l}\text { Search, collection and } \\
\text { transcription from } \\
\text { archives, collection of } \\
\text { images and sound, } \\
\text { questionnaires of oral } \\
\text { history }\end{array}$ & $\begin{array}{l}\text { Scattered condition of } \\
\text { written and graphic } \\
\text { documents, quality } \\
\text { and format of sound } \\
\text { archives, availability } \\
\text { of interpreters to be } \\
\text { interviewed }\end{array}$ \\
\hline $\begin{array}{l}\text { History of interpreta- } \\
\text { tion in a historical } \\
\text { period (e.g., Antiquity, } \\
\text { Middle Ages) }\end{array}$ & $\begin{array}{l}\text { Historical and diplo- } \\
\text { matic archives, chroni- } \\
\text { cles, corpora, history } \\
\text { books, museums }\end{array}$ & $\begin{array}{l}\text { Selection, transcrip- } \\
\text { tion, compilation, } \\
\text { interpretation, use of } \\
\text { IT for information pro- } \\
\text { cessing }\end{array}$ & $\begin{array}{l}\text { Scarcity of references } \\
\text { to interpreters in } \\
\text { archives, chronicles, } \\
\text { etc.; not all corpora } \\
\text { available in easy-to- } \\
\text { review IT media; } \\
\text { palaeographic skills }\end{array}$ \\
\hline $\begin{array}{l}\text { History of interpreta- } \\
\text { tion in a country or } \\
\text { territory }\end{array}$ & $\begin{array}{l}\text { Chronicles, official } \\
\text { archives, private } \\
\text { archives (of national } \\
\text { associations, inter- } \\
\text { preters, for example), } \\
\text { professional associa- } \\
\text { tions' bulletins, the } \\
\text { media, interpreters } \\
\text { themselves (memoirs, } \\
\text { personal interviews) } \\
\end{array}$ & $\begin{array}{l}\text { Search, analytical } \\
\text { work, oral history }\end{array}$ & $\begin{array}{l}\text { Access to archives } \\
\text { (particularly private } \\
\text { ones), fragmentary } \\
\text { and scattered } \\
\text { information, access } \\
\text { to interpreters (age, } \\
\text { willingness) }\end{array}$ \\
\hline $\begin{array}{l}\text { History of interpreters } \\
\text { at an international } \\
\text { organization (IO) }\end{array}$ & $\begin{array}{l}\text { Archives of the IO, } \\
\text { literature on the IO, } \\
\text { interviews with the IO } \\
\text { staff or freelance inter- } \\
\text { preters or with others } \\
\text { (administration, users, } \\
\text { linguistic staff), the } \\
\text { media } \\
\end{array}$ & $\begin{array}{l}\text { Search, analytical } \\
\text { work, oral history }\end{array}$ & $\begin{array}{l}\text { Legal constraints for } \\
\text { access to personnel } \\
\text { dossiers or others in } \\
\text { the IO; access to inter- } \\
\text { preters and other } \\
\text { potential informants }\end{array}$ \\
\hline $\begin{array}{l}\text { History of interpretation } \\
\text { at an institution (e.g., } \\
\text { a Ministry for Foreign } \\
\text { Affairs or a multilingual } \\
\text { parliament) or of a } \\
\text { professional association } \\
\text { (national or inter- } \\
\text { national) }\end{array}$ & $\begin{array}{l}\text { Archives of the institu- } \\
\text { tion or association } \\
\text { (bulletins, correspon- } \\
\text { dence, etc.); references } \\
\text { in history books and } \\
\text { the media; interviews } \\
\text { with interpreters and } \\
\text { others }\end{array}$ & $\begin{array}{l}\text { Search, analytical } \\
\text { work, oral history }\end{array}$ & $\begin{array}{l}\text { Legal constraints for } \\
\text { access to archives; } \\
\text { access to interpreters } \\
\text { or other potential } \\
\text { informants }\end{array}$ \\
\hline
\end{tabular}




\begin{tabular}{|c|c|c|c|}
\hline $\begin{array}{l}\text { History of court inter- } \\
\text { preting (in general or } \\
\text { limited to a multilin- } \\
\text { gual court) }\end{array}$ & $\begin{array}{l}\text { Historical literature } \\
\text { about the court(s), } \\
\text { court archives and } \\
\text { records, testimonies by } \\
\text { interpreters, adminis- } \\
\text { tration, users, etc. }\end{array}$ & $\begin{array}{l}\text { Search, analytical } \\
\text { work, cross-reference } \\
\text { of data, oral history }\end{array}$ & $\begin{array}{l}\text { Legal restriction for } \\
\text { access to confidential } \\
\text { sources; access to } \\
\text { interpreters and other } \\
\text { informants }\end{array}$ \\
\hline $\begin{array}{l}\text { Sound history of inter- } \\
\text { pretation (general or } \\
\text { specific to an institu- } \\
\text { tion, territory, etc.) }\end{array}$ & $\begin{array}{l}\text { Sound archives from } \\
\text { public and private } \\
\text { institutions, radio, } \\
\text { museums, and so forth }\end{array}$ & $\begin{array}{l}\text { Search, retrieval, digi- } \\
\text { talization, classifica- } \\
\text { tion, presentation } \\
\text { (sound and text) }\end{array}$ & $\begin{array}{l}\text { Access to materials } \\
\text { (preservation, format, } \\
\text { legal restrictions, copy- } \\
\text { right constraints) }\end{array}$ \\
\hline $\begin{array}{l}\text { Image history of inter- } \\
\text { pretation (general or } \\
\text { specific to an institu- } \\
\text { tion, territory, etc.); } \\
\text { interpreters in action }\end{array}$ & $\begin{array}{l}\text { Film archives, TV } \\
\text { archives, museums, } \\
\text { and so on; specialized } \\
\text { literature; the media }\end{array}$ & $\begin{array}{l}\text { Search, retrieval, digi- } \\
\text { talization, classifica- } \\
\text { tion, presentation } \\
\text { (image and text) }\end{array}$ & $\begin{array}{l}\text { Access to materials } \\
\text { (preservation, legal } \\
\text { restrictions, copyright } \\
\text { constraints) }\end{array}$ \\
\hline $\begin{array}{l}\text { Interpreters in fiction } \\
\text { films }\end{array}$ & $\begin{array}{l}\text { Film and video } \\
\text { archives; specialized } \\
\text { movie literature }\end{array}$ & $\begin{array}{l}\text { Search of relevant } \\
\text { scenes; translation } \\
\text { and transcription of } \\
\text { original soundtrack; } \\
\text { classification; presen- } \\
\text { tation (e.g., dubbed, } \\
\text { subtitled) }\end{array}$ & $\begin{array}{l}\text { Topic choice (for } \\
\text { instance, WW2 films or } \\
\text { westerns); variety of } \\
\text { media (celluloid, differ- } \\
\text { ent video systems, } \\
\text { DVD); scattered nature } \\
\text { of film and video } \\
\text { archives; access and } \\
\text { copyright restrictions }\end{array}$ \\
\hline $\begin{array}{l}\text { History of media } \\
\text { interpreting }\end{array}$ & $\begin{array}{l}\text { Sound and TV archives, } \\
\text { literature on the topic }\end{array}$ & $\begin{array}{l}\text { Search of illustrative } \\
\text { examples; translation } \\
\text { and transcription; } \\
\text { presentation }\end{array}$ & $\begin{array}{l}\text { Access constraints } \\
\text { (preservation, legal } \\
\text { restrictions); } \\
\text { interpreters' and } \\
\text { companies' copyright } \\
\text { restrictions }\end{array}$ \\
\hline $\begin{array}{l}\text { Specific historical } \\
\text { interpreting situations } \\
\text { (e.g. Moctezuma and } \\
\text { Cortés in Mexico) }\end{array}$ & Chronicles, archives & $\begin{array}{l}\text { Selection of materials, } \\
\text { cross-reference; recon- } \\
\text { struction of the situa- } \\
\text { tion; reinterpreting } \\
\text { sources }\end{array}$ & $\begin{array}{l}\text { Scarcity of sources, } \\
\text { palaeography, source } \\
\text { interpretation difficul- } \\
\text { ties }\end{array}$ \\
\hline $\begin{array}{l}\text { Technological evolu- } \\
\text { tion in the history of } \\
\text { interpreting }\end{array}$ & $\begin{array}{l}\text { Archives (institutions, } \\
\text { engineering compa- } \\
\text { nies), museums, tech- } \\
\text { nicians, interpreters } \\
\text { (and their associa- } \\
\text { tions), the media }\end{array}$ & $\begin{array}{l}\text { Search for technologi- } \\
\text { cal devices, classifica- } \\
\text { tion through time, oral } \\
\text { history }\end{array}$ & $\begin{array}{l}\text { Scattered nature of } \\
\text { technological devices } \\
\text { through time and } \\
\text { space, access to private } \\
\text { companies' files, techni- } \\
\text { cians and interpreters }\end{array}$ \\
\hline $\begin{array}{l}\text { The history of interpre- } \\
\text { tation training } \\
\text { (in general, focused on } \\
\text { a school or group of } \\
\text { schools) }\end{array}$ & $\begin{array}{l}\text { Archives (Foreign } \\
\text { Affairs and Education } \\
\text { Ministries, schools), } \\
\text { school staff, memoirs } \\
\text { and other books, inter- } \\
\text { preters, alumni }\end{array}$ & $\begin{array}{l}\text { Legislation on educa- } \\
\text { tion, schools' statistical } \\
\text { data compilation and } \\
\text { processing, oral history } \\
\text { for qualitative data }\end{array}$ & $\begin{array}{l}\text { Access to archives } \\
\text { (particularly to school } \\
\text { files), access to staff } \\
\text { and alumni }\end{array}$ \\
\hline $\begin{array}{l}\text { Interpreter characters } \\
\text { in fiction literature }\end{array}$ & $\begin{array}{l}\text { Literary works, previ- } \\
\text { ous research on the } \\
\text { subject }\end{array}$ & $\begin{array}{l}\text { Search, compilation, } \\
\text { analytical work, inter- } \\
\text { pretation (fiction vs. } \\
\text { reality) }\end{array}$ & $\begin{array}{l}\text { Choice of languages, } \\
\text { countries, periods or } \\
\text { authors }\end{array}$ \\
\hline $\begin{array}{l}\text { The history of sign } \\
\text { language interpreting } \\
\text { (general, in a country, } \\
\text { etc.) }\end{array}$ & $\begin{array}{l}\text { Books, archives (institu- } \\
\text { tions and associations), } \\
\text { interpreters and users }\end{array}$ & $\begin{array}{l}\text { Search and compila- } \\
\text { tion of relevant data, } \\
\text { oral (or sign language) } \\
\text { history techniques }\end{array}$ & $\begin{array}{l}\text { Differences among } \\
\text { sign language sys- } \\
\text { tems, communication } \\
\text { with users }\end{array}$ \\
\hline
\end{tabular}


The place of history of translation and interpreting in training programs

We propose that at least some notions of the history of the profession be taught in all interpreting training programs. The contents and the format may vary, according to the level of training, from a basic introduction to one or more seminars to a specific course (in Ph.D. programs, for instance). The contents should not be static but reflect the evolution of research in the field and new paradigms or approaches. They should adapt to the place and the circumstances in which the training takes place, focusing each time on relevant issues for the students. Basic texts and materials could constitute the basis for analysis, interpretation and discussion. A general overview could include reflections about the beginnings of the history of interpreting, with references to the works of Ingrid Kurz on ancient Egypt and ancient Rome. We could continue with references to the Middle Ages, perhaps with the example of Toledo, studied by Clara Foz, where the linguistic skills of Spanish Jews were used to translate a series of important works some of Greek origin — from Arabic into vernacular Spanish and/or to Latin through oral sight-translation techniques. The interpreters of the New World between the fifteenth and seventeenth centuries could be the subject of another chapter. The outlook of both sides, the conqueror and the other, could be studied from the perspective of the Renaissance chroniclers and that of postcolonial studies. The school of jeunes de langues and the figure of the dragomans could also be part of the chapter. Regarding contemporary history, we would propose a unit which should include, among other topics, the following: the beginnings of the conference interpreter profession as we know it (the 1919 Paris Peace Conference and League of Nations); the Nuremberg Trial and the coming of age of simultaneous interpreting; the United Nations (consolidation of the profession, simultaneous revolution, feminization of the profession, and the ongoing IT revolution); bilingual or multilingual interpreting in other institutions (the Canadian Parliament, the European Union); court interpreting; social services interpreting; media interpreting. 


\section{Conclusions}

The end of bistory was forecast some time ago, in a triumphalist manner, by some prophets of the new era. Luckily, history adamantly fails to stop, as Fontana (1992) rightly pointed out, reacting to Fukuyama's book. And as for the history of interpreting - and to a certain extent also the history of translation - we are only beginning.

The title of this book, Charting the Future of Translation History, stresses that we should see the history of our profession as a past for our future, that is, with predictive value for those who will follow us, taking advantage of the lessons learned from past experience. We owe our effort to recover our past to those who contributed to our professions, to our present colleagues, to the translators and interpreters that we are training now, and also to our societies in general. The results of our research should transcend our captive audience, because what we say may be of relevance for many professionals and scholars who work in other fields of study and research.

JESÚS BAIGORRI-JALÓN University of Salamanca

(Spain)

\section{References}

Primary sources

Baigorri-Jalón, J. (2003). "Conference Interpreting: Evolution and Revolution. Notes on the Feminisation of the Profession." Estudos de Tradução: Actas de Congresso Internacional, eds. M. Z. Gonçalves de Abreu and M. De Castro. Cascais: Principia, 27-34.

Delisle, Jean. (1997-98). "Réflexions sur l'historiographie de la traduction et ses exigences scientifiques." Équivalences, 26:2 and 27:1, 21-43.

Fontana, J. (1992). La bistoria después del fin de la bistoria. Barcelona: Crítica.

Woodsworth, J. (1996). "Teaching the History of Translation." In Teaching Translation and Interpreting 3. New Horizons, eds. C. Dollerup and V. Appel. (Papers from the Third Language International Conference, Elsinore, Denmark, June 9-11, 1995.) Amsterdam and Philadelphia: John Benjamins, 9-17. 


\section{Secondary sources}

Arencibia, Lourdes. (1993). "Apuntes para una historia de la traducción en Cuba." Livius, 3, 1-17.

Balliu, C. (1997). "L'École des Enfants de Langues del s. XVII: la primera escuela de interpretación en Francia." In La palabra vertida. Investigaciones en torno a la traducción, eds. M. A. Vega and R. Martín-Gaitero. Madrid: Universidad Complutense de Madrid, 251-260.

Bowen, M. (1992). "Negotiations to End the Spanish-American War." In Translation Studies: An Interdiscipline, eds. M. Snell Hornby et al. Amsterdam and Philadelphia: John Benjamins, 73-81.

Delisle, Jean. (1977). "Les pionniers de l'interprétation au Canada." META, 22:1, $5-14$.

(1977). "Projet d'histoire de la traduction au Canada." META, 22:1, $66-71$.

. (1977). "Les interprètes français au Brésil au XVIe siècle." Le Linguiste/De Taalkundige, 1:2, 1-4.

. (2003). "La historia de la traducción: su importancia para la Traductología y su enseñanza mediante un programa didáctico multimedia y multilingüe," trans. Anna María Salvetti. SENDEBAR, 14, 5-16. , and J. Woodsworth, eds., dirs. (1995). Les traducteurs dans l'bistoire.

Ottawa: Les Presses de l'Université d'Ottawa. Éditions UNESCO.

Foz, Clara. (1987). "El concepto de Escuela de Traductores de Toledo (ss. XII-XIII)." In Fidus Interpres. Actas de las Primeras Jornadas Nacionales de Historia de la Traducción, eds. J. C. Santoyo et al. Vol. 1. León: Secretariado de Publicaciones de la Universidad de León, 24-30.

Kurz, Ingrid. (1985a). "The Rock Tombs of the Princes of Elephantine. Earliest References to Interpretation in Pharaonic Egypt." Babel, 31:4, 213-218. . (1985b). "Das Dolmetscher-Relief aus dem Grab des Haremhab in Memphis. Ein Beitrag zur Geschichte des Dolmetschens im alter Ägypten." Babel, 32:2, 73-77. . (1986). "Dolmetschen im alten Rom." Babel, 32:4, 215-220.

Santoyo, J. C. (1999). Historia de la Traducción: Quince Apuntes. León: Ediciones Universidad de León. 


\title{
Subjectivity and Rigour in Translation History
}

\author{
The Case of Latin America ${ }^{1}$
}

Daul Veyne's quip "History has no method" (1978) is an invitation to
re-examine the methodology of translation history and is particularly germane to Latin America, where many Eurocentric concepts are inapplicable.

After a brief review of the methodology of translation history, both in general and with special attention to Latin America, this paper discusses some issues specific to translation history research in this region and the place of subjectivity and rigour in translation history. Finally, some guidelines for future research are proposed.

\section{Review of methodology}

It is no exaggeration to say that a good part of current translation history methodology is "normative" and quite often "negative," emphasizing what researchers "should not do." Jean Delisle (1997), to cite a notable example, starts by asking "how to write the history of translation" and 
continues on to claim that it is necessary to "write history like historians do." Delisle's five anachronic ways of "doing translation history," it will be recalled, are: 1. chronicles or annals (chronological series of translation-related events), 2. catalogues of translation (useful, but not historical), 3. compilations of first-person accounts (neither historical summaries nor theoretical), 4. anecdotal narratives (only useful if true, verifiable, and relevant), and 5. biographical anthologies (usually more passionate than objective). For Delisle, history must be more than the mere description of events and must also include an interpretive element.

Anthony Pym (2001) recommends that every study take translators as its starting point and proceed subsequently to a consideration of intercultural questions. His typology of historical research comprises three types of studies: 1 . anecdotal-dilettante (based on a single event, author, or text; despite inadequate data, claims to provide generally applicable results; useful, but uncritical and often of questionable value) ${ }_{i}$ 2. archaeological or historiographical (present all the available data related to an event, author, or text; useful by virtue of their restitution of fragments of a translation heritage, but ultimately incomplete and unsatisfying) ${ }_{i}$. interpretative (discuss and interpret the general applicability of all the available data related to an event, author, or text, and communicate findings).

In 1998, Pym also enunciated four framing methodological principles: 1. study the "why," that is, the social cause $;$ 2. study the "who" rather than the texts; 3 . study translators' social contexts; 4 ) study the past to shed light on the future.

Lieven D'hulst (2001), for his part, listed some basic questions that should be posed in any research on translation history: Why? What is the intellectual biography of the translators? What? What has and has not been translated? (The answer to this question requires translation bibliographies of various types: general, specialized, national, historical, and so forth.) Where? Where were the translations executed, printed, published, and distributed? Who was responsible for these tasks and why? Where did translation studies specialists work? Where were the 
schools? With what? What support was provided for the execution of the translations? Was there sponsorship or censorship? What power relationships framed the translations? Why? For whom were the translations executed? Why were the texts translated the way they were? (Even if the answers are only hypothetical, they have heuristic value.) How? How were the translations produced (assuming it is possible to reconstruct the process)? According to the standards of a specific time? According to new historical or geographic standards? When? What point in history does the research focus on? To what end? What was the impact of the translation? What was its goal? To what use did the target culture put it?

Samuel López Alcalá (2001), inspired largely by Brigitte Lépinette (1997), presents two analytical models: sociocultural and historicaldescriptive. The sociocultural model situates the phenomenon of interest in the sociocultural contexts of production and reception. The historical-descriptive model includes both descriptive-comparative and descriptive-contrastive studies. Descriptive-comparative studies are diachronic studies that compare theories of translation and the evolution of metaconcepts in translation studies. Descriptive-contrastive studies, on the other hand, analyze translations of the same source text in order to identify the strategies adopted by different translators.

Paul St-Pierre (1993), in turn, proposed a discursive approach to translation that seeks not "to determine whether a translation transforms and thus - as conventional wisdom would often have it betrays an original text, but rather . . bow such a transformation is carried out and the conditions which make it possible" $(1993,82)$. In other words, his approach recognizes that translation is a historical discourse that "contributes to an awareness of the elements underlying one's own culture, conditioning the definition of one's collective self in terms of (and very often in denial of) another, the other" $(1993,61)$.

This brief overview demonstrates that emphasis has clearly, indeed inevitably, been placed on historiographical rigour. (Some methodological errors with serious consequences will be discussed below.) The importance of objectivity has also been emphasized, even if the interpretation of historical facts, recommended by all authors, leads 
researchers down the path of subjectivity. And it is precisely the place of subjectivity in the study of Latin American translation that calls for some nuancing and clarification.

\section{State of the question in Latin America}

Prior to the 1980s, cultural studies of Latin America - whether historical, literary, sociological, or political — reflected an essentially Eurocentric vision of the subcontinent and its peoples. According to this perspective, "bourgeois humanism" is the primary expression of a nation's liberal utopian characteristics of homogeneity, consensuality, and discipline. This is hardly surprising since "by virtue of the universality of the European historical experience, the forms of knowledge developed for the understanding of this society have become the only valid, objective, and universal forms of knowledge" (Lander 2003, 23). ${ }^{2}$

The current state of affairs in cultural studies can be summarized as follows:

1. Latin America is still often perceived and studied in terms of the civilization/barbarism dichotomy, as if the 1970s epistemological turn in ethnography (Buzelin 2004) had left historians and sociologists untouched. Under the aegis of European condescension and magnanimity, the history of Latin America could be said to have "evolved" from the noble savage (of Las Casas) to the noble revolutionary (of Che Guevara). Carlos Rangel's 1976 essay is a perfect illustration and interpretation of this evolution. Such a typically reductive vision is inherently unable to take in all the complexity of the cultures that it persists in casting, all things considered, as "primitive." And, of course, it rejects the very notion of "métissage" (Laplantine and Nouss 1997) as insolent in its simplicity. It is this vision which is responsible for the expression "the discovery of America by Christopher Columbus," despite the fact that 300 million speak of "the discovery of Christopher Columbus by America."

2. In general, historical surveys have tended to adopt the universalistic structures of European history and have grouped the centuries into 
classical (the first human migrations), medieval (indigenous civilizations), Renaissance (adoption of European cultural and intellectual capital), and modern (timidly conceded) periods. Such anachronistic periodization is inconceivable today.

3. Racist beliefs continue to shade many studies. One need only glance at the opening pages of the latest edition of the Histoire de l'Amérique latine (Chaunu 2003):

To talk about Latin America is to affirm the unity of that world, as opposed to Anglophone America, and to the 215 million people whose alien mouths speak, for the most part, more or less deformed Iberian languages. ${ }^{3}(3)$

The most brilliant Indian civilizations yielded to European culture with exceptional rapidity. A congenital weakness of the Indians? ${ }^{4}$ (4)

This result [the collapse of indigenous cultures] is perhaps more the result of societal superiority than of technical superiority. ${ }^{5}$

The author of this history, Pierre Chaunu, does not miss any opportunity to evoke the spectre of the "cruel mythology" of the indigenous populations or to underscore the fact that there was "no cohesion between peoples, no internal social cohesion" (5).

4. As Angel Rama (1984) has pointed out, recorded history is the history of the elites, particularly the city-dwelling and lettered elites. Of the literate and urban, therefore. Since the sixteenth century, indeed, the "lettered city" has been the centre of decision making and executive power, the religious, administrative, educational, professional, and cultural heart of society. "The masters of literacy in illiterate societies . . . proceeded to sacralize it, in keeping with the constitutive grammatological tendency of European culture."6 (Rama 1984, 33). Although faithful to sociopolitical realities, this history overlooks 
the contribution, non-negligible at the very least, of "uncultivated" populations to the cultural, political, and social life of the subcontinent. For, in point of fact, "the letter was always obeyed, although in reality it was not followed, and this was as true during the colonial period, with its royal schedules, as it was during the Republic, with its

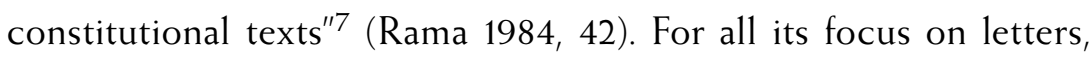
however, this history remains silent about a secondary "literature" (newspapers, correspondence, graffiti) worthy of mention.

5. Hispano-American history is characterized by an overemphasis on the French Revolution in comparison with the American Revolution. According to Grases (1981, 271),

The cliché which would have the influence of the French Revolution be the determinant factor in the emancipation of Hispano-America has persisted for two hundred years. Today, not only is this claim questioned, but increasing documentary evidence indicates that the ideology and success of the independence of the United States were key elements in the fate of the Spanishspeaking continent. ${ }^{8}$

Another determinant factor, according to Grases, was the "spirit of liberty profoundly rooted in the Hispanic nature." There is other convincing evidence that the American declaration of independence of 1776 (and subsequent declarations) played a greater role in Hispanic America than did the French declaration of 1789. As Brewer Carías (1992, 202-203) notes:

The goal of the French declaration was not the establishment of a new state rather, it was adopted as a revolutionary act within a pre-existing national, monarchic state. The American declarations, in contrast, were acts of protest destined to construct new states and, by extension, new citizens. ${ }^{9}$ 
6. Recorded history (and culture) are essentially "evenemential" (Veyne 1978): they are limited to elites, "great men," and the grand texts of conventional history. The incontestably great names of Latin American translation include La Malinche and Felipillo in the colonial period, and Borges and Paz in the contemporary period. However, this perspective neglects the entire span of "non-evenemential" translation history, which is to say the body of translational acts performed by less glorious actors such as educational institutions, newspapers, magazines, government departments, "tertulias," and salons. As Julio-César Santoyo states in this very volume, it is in fact the entire history of translation in Latin America which is "blank."

These Eurocentric models or approaches were inevitably adopted by many Latin America scholars. It was only in the 1980s that a generation of researchers appeared - literary critics for the most part (Angel Rama, Antonio Cornejo Polar, Nestor García Canclini, Beatriz González Stephan, amongst others) - intent on better reflecting the complexity of the Latin American reality that escaped the binary and homogenizing canonical or official Eurocentric models. Unfortunately, so little translation history research of this sort has been conducted that it is impossible to cite examples of its orientation or results (see, however, http://www.histal.umontreal.ca).

\section{General principles for a history of Latin American culture}

In light of the situation outlined above, a shift from a simple to a complex paradigm is imperative. "It becomes obvious that these concepts of acculturation and assimilation fail to take into account the complexity of the processes of cultural contact, i.e. the dynamics of intrusion and disjunction" ${ }^{10}$ (Simon 1999, 30). Accordingly, a conceptual framework for the analysis of various specifically Latin American sociocultural situations and phenomena has been developed.

The first feature of this framework is HYBRIDITY. According to Néstor García Canclini (1989), hybrid cultures are intercultural blends 
that incorporate practices from popular cultures into their general cultural reference systems. Hybridity should not be confused with "métissage," which, in Latin America, has ethnic or racial connotations, or with "syncretism," which refers to the merging of religions or of traditional symbolic movements (1989, 14-15).

Sherry Simon (1999), in her work on cultural encounter and exchange in countries like Canada and cities like Montreal, also espouses the concept of hybridity. For Simon, hybridity is distinct from syncretism, creolization, and métissage, which "suggest that the dynamic of cultural meetings gives rise to new, long-lasting identities"11 $(1999,31)$. In fact, she claims the hybrid is "not a new synthesis, not an end,"12 and endorses Homi Bhabha's observation that hybridity is a "third space" (quoted by Simon 1999, 31), a zone of negotiation, dissent, and exchange, the locus of "a 'translational culture' that short-circuits patterns of alterity in order to express the drift of contemporary identities $^{\prime \prime 13}$ (1999, 39-40). It should be noted, in passing, that this concept of "transculturation," found in Bhabha and Simon ${ }^{14}$ amongst others, is a product of Latin America, having been advanced by the Cuban Fernando Ortiz (1947) ${ }^{15}$ to take into account the

highly varied phenomena that have come about in Cuba as a result of the extremely complex transmutations of culture that have taken place here, ... either in the economic or in the institutional, legal, ethical, religious, artistic, linguistic, psychological, sexual, or other aspects of its life. (Ortiz 1947, 98)

Other concepts that are useful in explaining both the complexity and the transitional yet enduring nature of Latin American cultures include Antonio Cornejo Polar's (1994) "contradictory totality" and "non-dialectical heterogeneity," as well as Oswald de Andrade's (1928) "anthropophagy."

Cornejo Polar's $(1982,49)$ CONTRADICTORY TOTALITY is a cultural totality composed more of contradictions than of harmonies, a space filled with internal contradictions. It is, however, useful to 
emphasize that "contradictory" is synonymous not with "tension" but with "contradiction" and "paradox." NON-DiALECTICAL HETEROGENEITY is the term used by Cornejo Polar to reflect the experience of deterritorialization and cultural reinsertion. In Escribir en el Aire (1994), he explains the term:

Here, everything is mixed with everything, and the coarsest contrasts are juxtaposed, face to face, daily. The verbal representations of this intense and viscerally dislocated social village also impose codes of rupture and fragmentation. ${ }^{16}(1994,22)$

García Canclini's hybridity and Cornejo Polar's contradictory totality and non-dialectical heterogeneity are eloquent reflections of the transitional state of Latin America's search for identity, cultural claims making, and political affirmation. This heterogeneous and contradictory nature must be accepted if the efforts at emancipation, the later battles for independence, and the successive failures and triumphs in the establishment of republics, expressed in and through translations of European and North American books, declarations, letters, songs, and texts of other types, are to be analyzed.

Finally, a word about the "anthropophagy movement" that emerged from Brazil and has elicited much comment. In this context, "anthropophagy" has nothing in common with cannibalism, which is a typically European, "civilized" notion applied to a certain type of "barbarism" (see, however, Montaigne's argument in the Essais). The movement was initiated by Oswald de Andrade with his Antbropophagic Manifesto (1928), published in Brazil. Although originally intended as a comment on the visual arts, the ideas it enunciated rapidly influenced other disciplines. It is both an intensely political activist doctrine and a source of an immensely enriching creative practice that encourages creators, authors, to "nourish" themselves from foreign sources without however accepting their influence and traditional mimesis (Vieira 1994, 67). The movement seeks to strengthen indigenous literatures, encouraging them not only to retain all their own ethnic components but also to 
integrate indigenous elements into the foreign artistic forms they appropriate.

To fully grasp this sociocultural reality, it is useful to examine the three constitutive elements - sociocultural, political, and educational - of the still unrealized emancipator project embarked upon at the very moment Americans discovered Christopher Columbus. The goal of the first is the invention of a new citizen, for the simple reason that colonization prevented Latin Americans from continuing to be what they had been. The second, which arose in the eighteenth century, finds expression in uprisings and wars, but also in anti-colonial and antiimperialistic discourses intended to establish the foundations of political organization. The goal of the third, which also dates from the eighteenth century, is the training of future generations in universal, but American-inspired, knowledge. ${ }^{17}$

\section{Orientations for a history of translation}

The preceding discussion may seem at quite a remove from translation, but how can one discuss the transcultural (and, by extension, translation) without a knowledge of the cultural? This is a simple question of rigour, even though the concepts in play reflect a typically Latin American subjectivity.

It would be valuable, before "imported" models can establish themselves in this research field, to evaluate the applicability of the new paradigm, described above, to translation. Clearly, inapplicable periodizations and historical, anthropological, and sociological models are inappropriate bases for the evaluation of translation methodology and the impact of translators and translations. A specific, and thus subjective, vision is needed. Several guidelines can be derived from the preceding review of the situation and discussion of key concepts.

1. HISTORY MUST BECOME NON-EVENEMENTIAL. Veyne (1978, 32-34) tells us: "An immense non-evenemential space remains to be cleared!" This should not be difficult with respect to translation, as the 
act of translation has been too long considered a non-event, and thus unworthy of interest. While they use translation on a daily basis, historians have nonetheless never felt the need to make it one of their objects of study. The first step in the construction of the non-evenemential is the consideration of "minor," or grey, literature such as the press, pamphlets, columns, correspondence, and even graffiti. To this must be added "oraliture", tertulias, songs, theatrical performances, and other forms of oral expression. Lastly, translation history researchers should eschew the "great names" (generally famous poets and novelists) and seek out the throngs of neglected translators. Some authors have started to do precisely this, despite the omnipresent but understandable temptation - since translators are necessarily part of the "lettered," the privileged — to focus on the elites. ${ }^{18}$

2. LATIN AMERICAN TRANSLATION SHOULD NEVER BE HOMOGENIZED OR STRAITJACKETED. Latin American translation should be left heterogeneous, its contradictions embraced. While research to date clearly suggests that appropriation is the primary mode of Latin American translation, it is nevertheless clear that some contradictions must be addressed. These include Miranda's literal translation of Viscardo's Lettre aux Espagnols Américains, ${ }^{19}$ Nariño's Declaration of the Rights of Man, ${ }^{20}$ and some elements of the translations of Andrés Bello and Pérez Bonalde. Even Borges never attempted to hide his contradictions. ${ }^{21}$

3. RIGOUR IS THE PARAMOUNT VIRTUE OF RESEARCH. The often difficult and discouraging context of Hispano-American historiographic research is no justification for a lack of rigour. The following examples are telling illustrations of the importance of rigour.

a. Researchers are often obliged to scan certain documents because the originals are too fragile or are in a format (old forms of writing, spacing, font, and so on) that precludes optimal analysis. However, scanning is a double-edged sword: as with every rapidly developing technology, it is only reliable up to a point. For example, while scanning the Viscardo's Lettre, we failed to notice the omission of a 
sentence fragment. The resultant sentence remained logical and comprehensible but now had a radically modified meaning. It was only by pure chance that we spotted our error of interpretation, reflecting the new textual meaning resulting from our negligence, prior to the publication of the article.

b. Translation history research often requires exploration of primary historical sources (and, incidentally, sometimes identifies serious deficiencies in the sacrosanct rigour of historians). Indirect references (secondary or tertiary), although dangerous and methodologically risky, are thus rife. But researchers must be doubly vigilant when the absence of primary sources renders their use unavoidable. Dates taken from other research must be meticulously checked. We once claimed that a Spanish cleric had destroyed Mayan documents when in fact he was actually in Spain — in primary school!

c. Similarly, haste and negligence once led us to incorrectly state presumably because our source had been published in Mexico that Francisco Ayala is Mexican, when he is, as Carmen Acuña Partal $(1999,158)$ has quite rightly pointed out, actually Spanish.

d. Amazing and fascinating as it may be, the Google family of search engines is not infallible. During the graphical composition of the HISTAL home page, which presents several famous Latin American translators, we used Google Image to locate a portrait of Nariño, the first translator of the Declaration of the Rigbts of Man in Latin America. While we accepted Google Image's identification of the painting as a portrait of Nariño, it turned out to be of King Fernando VII of Spain.

e. The rigour of translators should be of no lesser quality than the much-vaunted rigour of historians. And translation history research may unearth some unexpected discoveries. For instance, no translation studies scholar would hesitate to attribute to Antoine Berman the first and perhaps only French translation of Schleiermacher's famous essay. However, a meticulous comparison of the Spanish (1978) and French (1985) translations, by Valentín 
García Yebra and Antoine Berman, respectively, ${ }_{1}^{22}$ reveals surprising syntactical and lexical similarities, suggesting, astonishingly, that Berman's French translation was not performed from the original German but rather from the Spanish translation! Although unconfirmed, this hypothesis is an eloquent demonstration of how historiographical research can also challenge received truths.

4. THERE IS SUCH A THING AS NECESSARY SUBJECTIVITY. Objective history is impossible, and would, in any event, be extremely boring. Interpretation implies subjectivity, as all the translation scholars cited in the literature review acknowledge, albeit to varying extents. The very choice of an object of study is a question of subjectivity. Even the organizational decisions related to the research product, including the table of contents, notes, and even the publisher, are unquestionably the fruit of researchers' personal and subjective visions.

It is our claim, therefore, that the essential and indispensable historiographical rigour of historical research must be accompanied by a subjectivity that reflects the nature of the object of study and that is, thus, itself a part of the method. In this light, the liberation of translation in Latin America from Eurocentrism and the fixation (often through canonical literature) on elites depends on the following points:

a. THE ADOPTION OF A SPECIFIC DISCOURSE, that is, the threefold discourse recommended by Briceño Guerrero (1993), the Venezuelan philosopher and philologist. According to Guerrero, Latin American emotional attitudes and political action involve three discourses: 1 . The second European discourse, imported in the late eighteenth century (at the time of the French Revolution), which encompasses rationalism, illustration, and social utopia; 2 . The Christian-Hispanic discourse, or mantuano, which governs Latin Americans' individual behaviour, family relationships, and feelings of dignity, honour, and happiness; 3 . The savage discourse, which finds expression in the most intimate emotions and relativizes the other two discourses through humour, intoxication, and a secret, 
global refusal. These are concomitant, heterogeneous, contradictory, but not dialectical discourses. This brings us back to our starting point.

b. THE ADOPTION OF A SPECIFICALLY HISPANO-AMERICAN PERIODIZATION rather different from the classic European model. In fact, the historical evolution of Latin American and European discourses are as different as their contents. This being so, their periodizations must also be different. We have previously (Bastin 1998) proposed the following periodization: Encounter and conquest (1492-1533, Christopher Columbus to the fall of Atahualpa and Moctezuma); Colonial period (sixteenth to eighteenth century); Pre-independence and Emancipation (1750-1830; first insurrections to the end of Gran Colombia); Independence and Republic (1830-1920); and 1920 to the present.

While it is still very difficult to trace the historical evolution of translation, given the paucity of relevant research, it is clear that this evolution had nothing in common with its European counterpart, marked by the coming and going between free and literal translation, the "belles infidèles," and "historical reconstitution." Andrea Pagni concluded his research on Andrés Bello thus: "We may conceive of translation as a practice of displacement that contributed to the emergence of new cultural paradigms, rather than as the more or less successful, but always inferior, repetition of previous cultural paradigms ${ }^{\prime \prime 23}$ (Pagni 2003, 354). This is precisely what Latin American translation is: displacing and creative, politically, economically, educationally, and culturally committed - a specific and, above all, appropriate practice and space.

c. THE REHABILITATION OF LOCAL CULTURAL SPACES to the detriment of the Eurocentric, colonial vision. It is here that subjectivity is most active. This rehabilitation is indispensable in Latin America (and other postcolonial situations), if only out of a concern for "historical truth." And it is here that the Latin American translator, confronted with Pierre Chaunu's Que sais-je?, after rectifying the racist statements, would translate the book as if the question 
had been "What should be known?" or "What should Chaunu have known?" rather than "What do I know?" Such rehabilitation can only be accomplished through the agency of specific concepts such as those described above. In the words of Aníbal Quijano (2003, 242): "It is time to stop being what we are not!"24

\section{Conclusion}

By emphasizing translators' methods and not text objects, a global transcultural approach could engender a true liberating role for translation. The analysis and interpretation of texts and translation strategies through the eyes and the peripheral way of living of those who translated, rather than through the "Western," elitist prism, requires a paradigm shift, a sort of deconstruction.

The Latin American-specific conceptual framework proposed here in the hope of orienting the research methodology of translation history has yet to be tested. In fact, although partially verified, it awaits confirmation by other, hopefully numerous, studies.

GEORGES L. BASTIN

Université de Montréal

(Canada)

\section{Notes}

1. I want to warmly thank Steven Sacks for his excellent translation of this article from French.

2. All translations are ours unless otherwise stated. "Precisamente por el carácter universal de la experiencia histórica europea, las formas del conocimiento desarrolladas para la comprensión de esa sociedad se convierten en las únicas formas válidas, objetivas, universales del conocimiento" (Lander 2003, 23).

3. "Parler d'Amérique latine, c'est affirmer l'unité de ce monde, en opposition à l'Amérique anglo-saxonne, et des 215 millions d'hommes qui parlent dans leur majorité, plus ou moins déformées dans des bouches étrangères, les langues castillane et portugaise" (Chaunu 2003, 3). 
4. "Les civilisations indiennes les plus brillantes ont cédé le pas à la culture européenne, avec une extraordinaire rapidité. Faiblesse congénitale de l'humanité indienne?" (Chaunu 2003,4)

5. "Plus que par la supériorité technique peut-être, cette issue [l'effondrement des cultures indigènes] s'explique par la supériorité des hommes" (Chaunu 2003).

6. "Los dueños de la escritura en una sociedad analfabeta ... procedieron a sacralizarla dentro de la tendencia gramatológica constituyente de la cultura europea" (Rama 1984, 33).

7. "La letra fue siempre acatada, aunque en realidad no se la cumpliera, tanto durante la Colonia con las reales cédulas, como durante la República respecto a los textos constitucionales" (Rama 1984, 42).

8. "Durante doscientos años ha predominado el clisé de que la influencia de la revolución francesa fue el factor determinante de la emancipación hispanoamericana. Hoy no sólo se pone en tela de juicio tal afirmación, sino que se acrecienta la documentada convicción de que la ideología junto con el éxito de la independencia de Norteamérica, fue un elemento activo en la decisión del continente que habla español" (Grases 1981, 271).

9. "La Declaración francesa no tenía por objeto establecer un nuevo Estado sino que se adoptó como acto revolucionario, dentro del Estado nacional y monárquico que ya existía. En las Declaraciones americanas, en cambio, se trataba de manifestaciones para construir nuevos Estados, y por tanto, nuevos ciudadanos" (Brewer Carías 1992, 202-203).

10."Il devient évident que ces notions d'acculturation et d'assimilation ne rendent pas compte de la complexité des processus de contact culturel: des dynamiques d'intrusion, de disjonction" (Simon 1999, 30).

11. ". . . suggèrent qu'à partir de la dynamique de la rencontre culturelle, des nouvelles identités durables seront nées" (Simon 1999).

12.". . . n'est pas une nouvelle synthèse, n'est pas un achèvement" (Simon 1999).

13. ". . . une 'culture translationnelle' qui court-circuite les schémas de l'altérité pour exprimer la dérive des identités contemporaines" (Simon 1999, 31).

14. "L'hybride signale l'avènement de l'ère où le préfixe dominant dans la description des relations entre les cultures n'est plus 'inter' mais 'trans'" (Simon 1999, 30).

15. "With the reader's permission, especially if he happens to be interested in ethnographic and sociological questions, I am going to take the liberty of employing for the first time the term transculturation, fully aware of the fact that it is a neologism" (Ortiz 1947, 97).

16. "Aquí todo está mezclado con todo, y los contrastes más gruesos se yuxtaponen, cara a cara, cotidianamente. Visceralmente dislocada, esta intensa comarca social impone también, como material de la representación verbal, códigos de ruptura y fragmentación" (Cornejo Polar 1994, 22). 
17. For an illustration of this threefold project from a translation perspective, see Bastin et al. (2005).

18. Payàs, Gertudris (2004).

19. Bastin and Castrillón (2004).

20. Bastin and Echeverri (2004).

21. Cristal, Efraín, (2002). (Review by G. L. Bastin in TTR XV:1 [2002], 247-251.)

22. Schleiermacher, F. (2000).

23. "Pero también podemos pensar la traducción como una práctica de desplazamiento constitutiva a la emergencia de nuevos paradigmas culturales, más que como mera repetición - mejor o peor lograda, pero siempre inferior - de paradigmas culturales previos" (Pagni 2003, 354).

24. "Es tiempo, en fin, de dejar de ser lo que no somos" (Quijano 2003, 242).

\section{References \\ Primary sources}

Acuña Partal, Carmen. (1999). Review of Routledge Encyclopedia of Translation Studies. TRANS, 3, 157-159.

Andrade, Oswald de. (1928). "Manifesto Antropófago." Revista de Antropofagia, 1, 1.

Bastin, G. L. (1998). "Latin American Tradition." In Routledge Encyclopedia of Translation Studies, ed. Mona Baker. London: Routledge, 505-512.

Brewer Carías, A.R. (1992). Reflexiones sobre la revolución americana (1789) y sus aportes al constitucionalismo modern. Caracas: Editorial Jurídica Venezolana, Cuadernos de la cátedra Allan R. Brewer-Carias de derecho administrativo, Universidad Católica Andres Bello.

Briceño Guerrero, José Manuel. (1993). El laberinto de los tres minotauros. Caracas: Monte Ávila Editores Latinoamericana.

Buzelin, H. (2004). "La traductologie, l'ethnographie et la production des connaissances." META, 49:4, 729-746.

Chaunu, Pierre. (2003). Histoire de l'Amérique latine. Paris: PUF, Que sais-je?

Cornejo Polar, Antonio. (1982). Sobre Literatura y Crítica Latinoamericanas. Caracas: CEPFHE, UCV.

Cornejo Polar, Antonio. (1994). Escribir en el aire. Lima: Editorial Horizonte.

Delisle, Jean. (1997-1998). "Réflexions sur l'historiographie de la traduction et ses exigences scientifiques," Équivalences, 26:2 and 27:3, 21-43.

D'hulst, Lieven. (2001). "Why and How to Write Translation Histories?" In Emerging Views on Translation History in Brazil, ed. John Milton, Sao Paulo: Humanitas/FFLCH/USP, CROP 6, 21-32. 
García Canclini, Nestor. (1989). Culturas bíbridas. Estrategias para entrar y salir de la modernidad. México: Grijalbo.

Grases, Pedro. (1981). Preindependencia y emancipación (Protagonistas y testimonios), Obras 3, Caracas: Editorial Seix Barral.

Lander, Edgardo, ed. (2003). La colonialidad del saber: eurocentrismo y ciencias sociales. Perspectivas latinoamericanas, Buenos Aires: Clacso.

Laplantine, F., and Alexis Nouss. (1997). Le métissage. Paris: Flammarion, coll. Dominos.

Lépinette, Brigitte. (1997). La bistoria de la traducción. Metodología. Apuntes bibliográficos. Vol. 14. Lynx.

López Alcalá, Samuel. (2001). La bistoria, la traducción y el control del pasado. Madrid: Universidad Pontificia Comillas.

Ortiz, Fernando. (1947). Cuban Counterpoint: Tobacco and Sugar. New York: Alfred A. Knopf.

Pagni, Andrea. (2003). "Traducción del espacio y espacios de la traducción: Les jardins de Jacques Delille en la versión de Andrés Bello." In Ficciones y silencios fundacionales. Literaturas y culturas poscoloniales en América Latina (Siglo XIX), ed. Friedhelm Schmidt-Welle,. Madrid: Iberoamericana-Vervuert, 337-356.

Pym, Anthony. (1998). Method in Translation History. Manchester: St. Jerome Publishing.

- (2001). "Interview with Anthony Pym." In Emerging Views on Translation History in Brazil, ed. John Milton, Sao Paulo: Humanitas/FFLCH/USP, CROP 6, 273-284.

Quijano, Aníbal. (2003). "Colonialidad del poder, eurocentrismo y América Latina." In La colonialidad del saber: eurocentrismo y ciencias sociales. Perspectivas latinoamericanas, ed. Edgardo Lander. Buenos Aires: Clacso, 201-246.

Rama, Angel. (1984). La ciudad letrada. Hanover: Ediciones Norte.

Rangel, Carlos. (1976). Del buen salvaje al buen revolucionario. Caracas: Monte Avila Editores.

Schleiermacher, Friedrich. (2000). Sobre los diferentes métodos de traducir, trans. and com. Valentín García Yebra. Madrid: Gredos.

Simon, Sherry. (1999). Hybridité culturelle. Montréal: Île de la tortue.

St-Pierre, Paul. (1993). "Translation as a Discourse of History," TTR, VI:1, 61-82. Veyne, Paul. (1978). Comment on écrit l'bistoire. Paris: Seuil.

Vieira, Else (1994). "A postmodern translational aesthetics in Brazil." In Translation Studies - An Interdiscipline: Selected Papers from the Translation Studies Congress, Vienna, 9-12 September 1992, eds. Mary Snell-Hornby, Franz Pöchhacker and Klaus Kaindl. Amsterdam/Philadelphia: John Benjamins, 65-72. 


\section{Secondary sources}

Bastin, Georges L., and Elvia Castrillón. (2004). "La Carta dirigida a los españoles americanos, una carta que recorrió muchos caminos . . .," Hermeneus, 6, $273-290$.

Bastin, Georges L., and Álvaro Echeverri. (2004). "Traduction et révolution à l'époque de l'indépendance du Venezuela," META, 49:3, 562-575.

Bastin, Georges L., Álvaro Echeverri, and Ángela Campo. (2005). "La traducción en América Latina: propia y apropiada," in Revista Estudios, ed. Andrea Pagni. Universidad Simón Bolívar.

Cristal, Efraín. (2002). Invisible Work. Borges and Translation. Nashville: Vanderbilt University Press. (Review by G. L. Bastin in TTR, XV:1 [2002], 247-251.)

Payàs, Gertrudis. (2004). "Translation in Historiography: The Garibay/LeónPortilla Complex and the Making of a Pre-Hispanic Pas." META, 49:3, $544-561$. 
This page intentionally left blank 


\title{
Translation, History and the Translation Scholar
}

Soyons sans illusions.

L'homme ne se souvient pas du passé $;$ il le reconstruit toujours.

L. FEBVRE

\begin{abstract}
7 here is no doubt that history and translation are bound together.
1 Translation represents not only a central process in historical work, but is, in itself, a historical practice. However, so far these ties have not forged connections across the two disciplines. It must be acknowledged that the difference between the status of translation and history in the research community is such that the use of translation by historians has long been considered "normal" and "natural," while translators studying the history of their profession (so far of little interest to those who are historians by trade) are in general careful not to identify themselves as historians. Based on this notion, this article will focus on two points: first, general issues concerning the role of history in the history of translation; second, the question of periodization, to show how it is fundamentally subjective and marked by its time as well as by the institution (in a greater sense) that produced it.
\end{abstract}




\section{Role of history}

First let us delve into questions which are important to scholars, who, without being historians by trade, study the history of translation with varying and sometimes uncertain outlooks on the proportions of history. Consider on this point the reflections of Pym regarding the role of history in the history of translation, ${ }^{1}$ an issue which is not clearly addressed, however, in his book devoted to the examination of methods used in constructing the history of translation.

What about the status of these two disciplines, history with a capital $\mathrm{H}$ (a large hatchet for the wink to Perec!) and translation? History - a noble discipline among the social sciences, a veritable institution in itself. History with its diverse fields of research, its periods (long and short), its current fields (economic, for a time), culture, social practices, beliefs, portrayals, ideas, women and youth; but also the history of war, of ideology. Furthermore, the duty of memory is now inseparable from historical practice and straddles the discipline between science and memory. One cannot forget also the entire issue of discourse of and on history, its writing, the plotting of the story, essential to the historian, the "how we write history" to reference Paul Veyne (1971). Lastly come into play the issue of historiography, the sometimes uncertain realm where knowledge and social demand strike an awkward balance, the equally important question of practices and methods, the many issues uncovered by this question, and even more importantly, the (contemporary) epistemological debate which relates to the role of historians as well as the objectivity of historical knowledge. From the positivist movement inherited from the nineteenth century to Marxist or structuralist scientism that marked the middle of the twentieth century - the claim of a historical truth, modeled on the idealized image of the natural sciences, driven by the scientific philosophy - the historical discipline has experienced a very thorough questioning of itself. Some of the questions are linked to the status of figures in history, others to its ability or inability to dissect and portray the event, not to mention the often difficult relationships the discipline has with sociology. Hence, in the end, the position, relativist par excellence, by which the realities of the past authorize, 
by their essence, by nature, each group, each community (think of American Black History or of the most radical movements of feminism) to conceive of its own norms of truth, the historical discourse now finally able to be considered a fiction among others. To cite only two examples, think of Hayden White in the United States or of Paul Veyne in France, for whom history is nothing more than a narrative in which the historian constructs a plot around certain ordered events according to editing chosen in light of the research subject, the theme under study. We return later to precisely this issue, in discussing periodization in the history of translation. There is no doubt that there was need to, and that there is still a need to, otherwise define the very concept of historical objectivity and broach the question of knowledge, historical or otherwise, as relevant to an ensemble of social practices, to avoid the stalemate of scientific dogmatism.

\section{a. Historia a Debate website}

These questionings on the status of history and of those who create it are particularly well addressed on a very interesting Internet site, built out of a series of contacts, reflections and debates. It is the Historia a Debate $^{2}$ site, under the direction of Carlos Barros, a history professor from Santiago de Compostela (Spain). The initiative grew from a desire to put forward a "critical position," inviting dialogue among various historiographical movements, mainly the continuism of the sixties and seventies, postmodernism, and the return to the old history, amusingly described by those in charge of the "last historiographical breakthrough" site. This site is an excellent example, unique in its genre and rare, of practical and completely relevant application of the Internet to propose and sustain debates on such vast topics as What is bistory or What are its main components or What are the most important tasks for the bistorian nowadays. The interesting part of this work actually lies in the fact that the format of the Web itself enables change and updates, as well as the interaction of numerous participants. Recently this site presented the results of an extensive international survey ${ }^{3}$ conducted 
between the months of March 1999 and the end of the year 2001, a survey aiming to give an overview of the state of the art, to offer a diagnostic on the state of the discipline, aiming to define it, to explain its methods, writing the present and the past. This survey is too vast to discuss in much detail here, but it is of great interest, particularly for "non-specialists," as are many translatologists. The survey addresses many points relating to possible definitions of the discipline (for example, "history is the science of society," "history is the science of humanity through time," or "history is not a science because it does not allow one to know the objective truth of past facts," or "all history is contemporary"). It raises questions such as "How does reflection on methodology interest historians? Historiography? The theory of history? The theory of society?" It explores the ways in which philosophers and thinkers such as Marx, Freud, Weber, Durkheim, Lévi-Strauss, Foucault, Habermas, Bourdieu, Derrida, and Ricoeur have influenced, or continue to influence, the work of historians. These issues that arise in history create history, and build histories connected to the sometimes moving and incomprehensible subject of translation; translators are not often considered.

\section{b. History in the bistory of translation}

Pym is not wrong when he points out the relative absence of history in the history of translation. Could this be due to a "chasse gardée" phenomenon, because translation historians consider themselves, as specialists in the field, authorized by this fact to trace the contours and determine the issues, their issues throughout centuries, in a position of reclamation, of defence (normal, incidentally, if the "ancillary status," to use the words of Berman - of the translator and of his or her practice throughout the centuries is to be considered)? But how do we know that the translator lies at the heart of the history of translation, as the approach adopted by a number of recent research projects (for instance Delisle's Translators in History and Portraits of Translators) on the history of translation seems to indicate. In other words, aren't we trying to make it 
happen? It is precisely the question of SUBJECT that is treated in the first proposal of the History Under Debate Manifesto that has around three hundred and ninety subscribers, mainly historians. The manifesto is presented in eight languages ${ }^{4}$ and includes sixteen methodological, historiographical and epistemological proposals. It touches upon issues that vary from the reclamation of "SCIENCE WITH A SUBJECT," which avoids both the outdated, naive objectivism of positivism and absolute postmodern subjectivism, to the defence of the ETHICAL FUNCTION of history by virtue of the role it plays in society and more particularly in its formation, the awakening of consciousness and the education of citizens. It does so by discussing the new scholarship which engenders not only the enlargement of the source concept but also the resorting to "non-sources" that embody the silences, the errors and the gaps in history [see Santoyo in this volume]. In other words, the "history built from ideas, hypotheses, interpretations," which enables it to discover, to construct, even to deconstruct sources, combines itself with the celebrated "history written with documents."

Thus the issue arises of knowing to what extent to pursue the hypothetical. To cite one example (among many), particularly interesting because it is related to translation history, let us mention the review of Pym's work Negotiating the Frontier: Translators and Intercultures in Hispanic History (2000) by Julio-César Santoyo. ${ }^{5}$ In this book Pym presents a great number of hypotheses, a great deal of interpretation, considered as mere speculation by Santoyo: "The reader will find a good sample of such speculation on the final pages (30-33) of the first chapter, with its fifteen would's, five perhaps's, six probably's, four might's, two imagine's, and two bypothetical's, besides a heavy dose of such other qualifying terms as apparently, possibly, likely, apparent, suppose, may and so forth." Clearly two visions of how to write history, two postures towards historical facts and objects, and two perspectives on how to present or represent the past. Debilitating relativism on one part? Manipulation of evidence? Too much confidence in the reality of the referent on the other? Too much emphasis on raw data? The reader will be able to draw his own conclusions; at the risk of sounding too ecumenical, can it be said that 
the two approaches do not need to be considered as exclusive, one from the other?

\section{Periodization}

The second point will address the topic of periodization, which we know to be indispensable, though at times it can also be problematic because it is so systematic. Thus, in the words of Antoine Prost (1996, 116):

History cannot do without periodization. But periods have a bad reputation in our profession. From Lord Acton, who declared a century ago, "Study problems, not periods," to radical critiques from Paul Veyne or François Furet, periods are a problem. Truly, the problem lies in the preconceived period, served-again period, the one inherited by historians, not the living one. Periodizing in itself is a generally accepted, legitimate practice, and no historian could do without it. It is the result that appears suspicious: the period as an arbitrary frame, a constraint that deforms reality. Because once built/constructed, the period as a historic object inevitably works autonomously. ${ }^{6}$ [our translation]

This issue can be quite delicate. If periodization constitutes an indispensable division for defining and delimiting historical evolution, as well as the historical object itself, it often appears to be arbitrary, or at times even inaccurate. The concept of century, base for the "constraints of periods," has been denounced by a number of historians. Other periods have been revisited: with respect to the limits of classical periodization which defines the Middle Ages as the period between the end of Antiquity and the beginning of the sixteenth century, Jacques Le Goff, conscious of the difficulty that such a periodization of short intervals would represent for general understanding, proposed a division of time into longer periods, with shorter sub-periods. Therefore, his long Middle Ages extend from the third to the nineteenth centuries, comprising a 
first period from the third to the tenth centuries, a second period from the tenth to the fifteenth centuries, and lastly a third period from the sixteenth to the nineteenth centuries. The unity of each period lies largely in the fact that technological phases do not evolve in marked fashion. As Le Goff states, the "era of the mill" will be replaced by the machine of the nineteenth century. The same occurs in the economic, social and "cultural" fields, as well as the eras of famine and of Christianity. To give another example, referring to the same period, let us mention Huizinga (1996) and his famous Autumn of the Middle Ages, a work originally published in 1919 in which he establishes three distinct periods, among others: a twelfth century described as "bubbly," a thirteenth century described as "central," and a fourteenth century christened the Autumn of the Middle Ages. It is evident that the temporal divisions will undergo modifications or changes relative to the issue under study. Let us cite just two examples from the medieval context. First, in reference to the subject of the early university institutions, consider the distinctions generally made between the twelfth and thirteenth centuries. At first, the school followed the instructor, and then later the instructors followed the school. In other words, before institutions appeared, the professor was central, attracting students from different places; later on, professors traveled to the large educational centres, schools and early universities. Clearly, the interest in this type of periodization lies in the fact that the structures and the organization of instruction would be close to the "object" of study. To continue within the realm of knowledge and teaching, let us mention the concept of The Renaissance of the Twelfth Century, a concept put forward by Charles Haskins (1970). It is perhaps Marc Bloch (1952) who best brought to light the artificial character of all periodization:

The Middle Ages, in fact, exist because of their limited pedagogical usefulness: it allows us to structure programs and provides a single name for learned techniques whose extension is far from being clearly determined within traditional dates. The Medievalist knows how to read old texts, can read charts and knows old French. It is something, 
of course. But it is insufficient in order to establish, through exact divisions, a science based on reality. ${ }^{7}$

The "translation object" has itself given rise to a number of periodizations that, if they served well to structure the topic of analysis by applying a certain number of categories or by proposing divisions deemed essential to the organization of knowledge in some way, have also fallen into the "most obvious teleological traps," to adopt (adapting it) ${ }^{8}$ the expression used by Jean-Frédéric Schaub (2003) in the work that he has recently dedicated to the relations between France and Spain, particularly in the seventeenth century. This is, in fact, my second point: are the temporal classifications not necessarily founded on an evolution which leads to an outcome that is an end in itself? In other words, do we not reduce these classifications to essentialism, to historical continuity and totality in which we know they do not constitute any pertinent hypotheses? Since it is periodized, the "translation object," which would refer to the product or the agent (the translator), appears to be outside the limits or points of contact and articulation of literatures and of the ensemble of intercultural and interlinguistic exchanges that exist within a vast movement. Furthermore, the various periodizations applied to this phenomenon over the course of the last fifty years demonstrate a variety of differing points of view and approaches. While some of these focus on practices, others prefer to reflect upon the surrounding theories. These periodizations or "divisions" allow us to focus on the actual facts of translation or on the reflections surrounding them and thus become better able to define them, explain them, and even analyze them within their own context, as well as in relation to other tendencies rather than in isolation. The periodizations also present the (translation) facts within a continuity, which sometimes confines them to idealization, assimilating, in a sense, the phenomena into a linear movement, a succession or natural chain of events which does not allow the periods of rupture or silences to show through. Neither does it demonstrate the relationships of domination, rather than negotiation, between languages, cultures and literatures. 
a. In 1969, Ljudskanov, for reasons associated with the political and intellectual context of that era, probably found the road of periodization to be the least bumpy or chaotic. He proposed structuring the practice of translation into the following four stages: Word for word translation during High Antiquity and Antiquity, Sense translation from the Early first century AD to the fifteenth century, Free translation from the sixteenth to the eighteenth centuries, and finally Adequate translation from the nineteenth century to what he calls the present day, that is to say, the end of the 1960s.

Ljudskanov's text is marked by the state of discourse of its era, in which the first studies in machine translation were conducted. From those studies arose an argumentation based on the illusion of a translational invariant.

The practice of adequate translation received a new impetus and rose to an even greater level of perfection thanks to the development of ideas within the Soviet school of translation, which, among others, gives the name to this historical type of translation (Ljudskanov 1969, 25).

In this article, the basic principles of the fourth and final category to which the Soviet School of Translation is associated are said to be founded on "the most progressive ideas that have been expressed in this field in the past" (ibid., 25, note 21), as well as on "the point of view of the Marxist-Leninists on the language of translation." In other words a "tradition," with all that this concept entails: two sides, part old and part new, but above all a construction based on the necessity to represent translation and its practices within a historical movement marked by progress and result.

b. In his 1975 work After Babel, which has since become famous, George Steiner proposed a periodization also comprised of four phases, but situating all translational practices from Cicero to the end of the eighteenth century within the same category. Steiner referred to this phase as empiricism, as he envisioned it to be "the epoch of primary 
statement and technical notation" (Steiner 1975, 236). A second phase corresponds for George Steiner to the hermeneutic approach, a stage where the theory and the reflections on what it means to understand a text predominate. This second stage, for George Steiner, gives to the subject of translation a clear philosophical aspect, and extends from Friedrich Schleiermacher (1813) to Valéry Larbaud (1946). A third stage, marked by automatic (machine) translation and formalism, begins, according to Steiner, in the forties and ends in the seventies. The practice and reflection on translation during this time is influenced by the research on automatic translation enhanced by structuralism and transformational generative grammars. Overlapping this period is a fourth, originating at the beginning of the sixties and marked by interdisciplinarity. Anthropology, sociology, philology, comparative literature, lexical statistics, sociolinguistics, and poetics are called upon to help in the effort to discover more about translation and to analyze its products, to explore its different facets.

c. Another periodization in four stages was proposed by Julio-César Santoyo in 1987. A first phase of oral translation extends from prehistory to 3000 years $\mathrm{BC}_{\text {; }}$ a second of written translation is determined from 2400 BC to Cicero. The period when reflections on translation arise stretches from Cicero to the end of the eighteenth century. "Real" theorization begins with Tytler (1791) and Schleiermacher and lasts into the eighties. The periodization here proposed presents a double decoupage between modalities, methods (opposing oral to written for example), reflections, and thoughts on translation. But are these distinctions valid? Can they be used as a base, a foundation? In other words, can they be considered true categories that allow analysis of structure? To provide another example from medieval times, one can say that in the case of the work carried out in Spain during the twelfth century, the use of an oral pivot language (Romance) was particularly important, and as a matter of fact central, to the transmission of knowledge from Arabic into Latin, in practical as well as in symbolic terms. As far as the distinction of practice from reflection or theory is concerned, although it has permeated the various discourses on translation for many years, it can 
hardly be taken for granted. It may certainly be said that the impact of information technologies on the profession has contributed to the discovery of more and more common ground and forums for discussion between translation professionals and scholars.

d. Let us turn now to one last periodization, namely the one proposed by Michel Ballard (1992) under the form of five general categories. The first, dubbed Sources, extends from Prehistory to the fourth century. During the second, from the fifth century to the fourteenth century, translation appears as a relay, one could say a go-between. The third covers the fifteenth and the sixteenth centuries, when translation goes hand in hand with discovery and the opening of new horizons. The fourth period is marked by the Belles infidèles in seventeenth-century France; this is for Michel Ballard the moment that gives birth to translation studies per se. The fifth and final category is called Divergences and Reactions (Divergences et Réactions): it begins in the seventeenth century and ends with Walter Benjamin (1892-1944). One cannot but see that this last category is in fact a vast reservoir that contains several centuries of practice and reflection on translation. In this temporal classification more than in any other one, the teleological movement is clear: translation practice and the reflections that surround it are structured around the predictive notions of sources, mediations that tend towards an end, and as a matter of fact, here, give way to the birth of translation studies. In this case, as in any other temporal classification, there is no mention of the presence or absence of translation nor of the gaps between and within periods: the object of translation is considered as natural and given, when it is in fact constructed and predetermined.

These different ways of (re)presenting translation history and of analyzing its objects in the wider sense (though we are far from the project of a universal history of translation put forward by the committee on translation history of the International Federation of Translators in the sixties) have no doubt been useful to translators and translation scholars. They might even have interested people from other disciplines, have provided a certain structure to our field, have applied a certain number of categories, and have established temporal limits and periods 
that have allowed us to give a shape to knowledge. But one cannot be blind to the fact that, as with any temporal classifications, they appear as preconstructions which accommodate the object of translation and present translation (process, products, and actors) as part of a teleological movement, as a practice that moves towards a determined and essential end. Through Michel Foucault and others, we have learned that practice opens the way to the object, not the other way around. This explains why it is now common to see the object of translation (practice or reflection on it) as moving and changing, influenced by different paradigms (linguistic, cultural, or deconstructionist). This new approach to translation and translation studies offers a perspective that presents the advantage of allowing us to look at translation objects not as givens but as constructions, as representations, structured by translation scholars into categories which themselves have a history and are based on different interests and power relations. We do not doubt that the time has come to critically re-evaluate such categories.

CLARA FOZ

University of Ottawa

(Canada)

\section{Notes}

1. Pym's article can be found on the HISTAL site (http://www.histal.umontreal.ca) launched at the University of Montreal by my colleague Georges L. Bastin and his research team.

2. This site exists in three languages. It was created in Spanish but is translated into English (History Under Debate) as well as French (L'Histoire en Débat). The translated versions do not do justice to the quality of the content. Clearly, they deserve the attention of a professional translator.

3. This survey, conducted with help from two research projects dealing with the state of history (L'état de bistoire) and the change of historiographic paradigms (Le changement de paradigmes bistoriographiques), was distributed to 30,000 historians around the world.

4. Spanish, but also two other languages used on the peninsula, Catalan and Galician, as well as French, Portuguese, English, German, and Italian. 
5. Santoyo (2002).

6. L'histoire ne peut se passer de périodisation. Pourtant, les périodes ont mauvaise réputation dans la profession. De Lord Acton il y a un siècle dont on a dit le grand précepte "Study problems, not periods" aux critiques radicales de Paul Veyne ou de François Furet, la période fait problème. Au vrai, il s'agit de la période toute faite, refroidie, de celle dont l'historien hérite, non de la périodisation vive. L'action de périodiser est unanimement légitime et aucun historien ne peut s'en passer. Mais le résultat semble pour le moins suspect. La période prend l'allure d'un cadre arbitraire et contraignant, d'un carcan qui déforme la réalité. C'est qu'une fois l'objet historique période construit, il fonctionne inévitablement de façon autonome.

7. Le Moyen Age, en vérité, ne vit que d'une humble petite vie pédagogique: contestable commodité des programmes, étiquette, surtout, de techniques érudites, dont le champ, d'ailleurs, est assez mal déterminé par les dates traditionnelles. Le médiéviste est l'homme qui sait lire les vieilles écritures, critiquer une charte, comprendre le vieux français. C'est quelque chose, sans doute. Pas assez, assurément, pour satisfaire, dans la recherche des divisions exactes, une science du réel.

8. Schaub $(2003,24)$ uses in French the expression "ficelles téléologiques les plus grossières."

\section{References}

Ballard, Michel. (1992). De Cicéron à Benjamin: traducteurs, traductions. Réflexions. Lille: Presses universitaires.

Bloch, Marc. (1949). Apologie pour l'bistoire, ou Métier d'bistorien. Paris: Librairie Armand Colin.

Chartier, Roger. (1998). Au bord de la falaise. L'bistoire entre certitudes et Inquiétude. Paris: Bibliothèque Albin Michel Histoire.

Eco, Umberto. (1994). "Traduction et langue parfaite." In Dixièmes Assises de la traduction littéraire. Arles 1993. Arles: Actes Sud, 191-207.

Foucault, Michel. (1966). Les mots et les choses. Une archéologie des sciences Humaines. Paris: Gallimard.

. (1969). L'archéologie du savoir. Paris: Gallimard.

Foz, Clara. (1998). Le traducteur, l'Église et le roi. Ottawa: Presses de l'Université d'Ottawa/Artois Presses Université.

Haskins, Charles. (1970). The Renaissance of the Twelfth Century. Cleveland and New York: World Publishing Company.

Huizinga, Johan. (1996). The Autumn of the Middle Ages, trans. Rodney J. Payton and Ulrich Mammitzsch. Chicago: University of Chicago Press. 
Le Goff, Jacques. (1977). Pour un autre Moyen Âge: temps, travail et culture en Occident. Paris: Gallimard.

Ljudskanov, Alexandre. (1969). Traduction bumaine, traduction mécanique. Documents de linguistique quantitative $\mathrm{n}^{\circ} 2$.

Prost, Antoine. (1996). Douze leçons sur l'bistoire. Paris: Seuil.

Pym, Anthony. (1992). "Complaint Concerning the Lack of History in Translation Histories." Livius, 1, 1-11.

Santoyo, Julio-César. (1987). Teoría y Crítica de la traducción: Antología, Bellaterra: Publicacions de la Universitat Autònoma de Barcelona. . (2002). Review of Negotiating the Frontier: Translators and Intercultures in Hispanic History by Anthony Pym. Target, 14:1, 185-188.

Schaub, Jean-Frédéric. (2003). La France espagnole: Les racines bispaniques de l'absolutisme Français. Paris: Seuil, Collection L'univers historique.

Steiner, George. (1975). After Babel: Aspects of Language and Translation. New York and London: Oxford University Press.

Torres Del Rey, Jesús. (2002). "Encuentros y desencuentros posmodernos con la didáctica de la traducción: lenguaje, cultura, poder y pedagogía." In Cartografías de la traducción, ed. Román Álvarez. Salamanca: Ediciones Almar, 233-278.

Veyne, Paul. (1971). Comment on écrit l'bistoire. Paris: Seuil.

White, Hayden. (1973). The Historical Imagination in Nineteenth Century Europe. Baltimore: Johns Hopkins University Press.

\section{Online resources}

HISTAL: http://www.histal.umontreal.ca

Historia a debate: www.h-debate.com 


\section{Literalness and Legal Translation Myth and False Premises}

Introduction

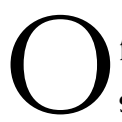

$f$ the many articles that have been written over the years on the subject of legal translation, only a few address the history of legal translation. ${ }^{1}$ This lack of interest is surprising since legal translation predates even Bible translation. For example, it is generally accepted that "the oldest known recorded evidence of legal translation is the Egyptian-Hittite Peace Treaty of 1271 BC" (Sarcevic 1997, 23). It would be both impossible and futile to try to pinpoint the reasons for this lack of interest. One of its consequences, however, is that many false or misleading statements have been made about legal translation through the ages. This article will discuss one of the most persistent and pervasive of those myths, which claims that the legal text was translated very literally for many centuries because of its authoritative status. Sarcevic, one of the foremost scholars in the field of legal translation, states that until the seventeenth century translations were "strict literal translations" and that only in the eighteenth and nineteenth centuries did translations become "literal translations." ${ }^{12}$ She provides 
the following figure on the evolution of legal translation (Sarcevic 1997, 31-32):

SARCEVIC'S MODEL OF THE

EVOLUTION OF LEGAL TRANSLATION

\begin{tabular}{llll}
\hline Strict literal Literal Moderately literal Idiomatic Co-drafting \\
\hline
\end{tabular}

However, Sarcevic does not take into account the idea that legal translation is only possible through the appropriation and reinvention of a legal text according to the period in which the text is translated. In this article, I will argue that the act of translation is closely bound to the translational goal of the translator, to the period in which the text is translated, and to the legal culture ${ }^{3}$ to which the text is translated and transferred, not to the authoritative status given to the original text. To support my argument, I will examine the possible origins of the myth of literalness in legal translation and its reformulation in the twentieth century. I will then provide examples from a translation of the Institutes done in thirteenth-century France.

\section{Possible origin of the myth}

The Corpus Iuris Civilis was compiled in the Byzantine Empire in the second half of the sixth century under the auspices of Justinian I (482-565). This compilation of Roman law consists of five separate texts: the Codex constitutionum, the Digest or Pandectes, the Institutes, the Codex Repetitae Praelectionis and the Novellae Constitutiones. In the proeminium of the Digest (Constitutio Tanta 21), Justinian prohibited anyone from appending "any commentary to these laws [Digest], save only insofar as he may wish to translate them into the Greek language in the same order and sequence as those in which the Roman words are written (kata poda, as the Greek call it)" (Watson). ${ }^{4}$ This restriction on the translation of the Digest, which is considered to be the oldest known written rule restricting the type of translation to be used when translating a legal text, had various consequences through the ages. For example, 
Stein states that Constitutio Tanta 21 was the main reason why the Corpus attracted "relatively little attention" (Stein 1999, 35) in the Byzantine Empire, since few Byzantine jurists could read and understand Latin well enough to make use of the compilation.

This regulation on translating the Digest seems to have contributed to the myth of literalness in legal translation in the twentieth and the twenty-first centuries. For instance, Sarcevic quotes Constitutio Tanta 21, explaining its inclusion in the Digest by the influence of the literalness topos used in Bible translation. According to Sarcevic, literalness in legal translation results from the authoritative status given to legal texts, a status similar to that given to the Bible. Because legal texts are authoritative documents, they were translated literally (Sarcevic 1997, 24-25). Furthermore, Sarcevic, following a short review of various articles and studies, states that legal texts were translated literally until at least the beginning of the seventeenth century; that the relationship between translator, "author," and public has been sterile for close to two millennia; and, finally, that the first "challenge to the literal translation of legal texts did not come until the twentieth century" ${ }^{\prime \prime}$ (Sarcevic 23ff). Notwithstanding the importance or value of that research or the influence of Tanta 21, the studies so far on the practice and evolution of legal translation through the ages are too few and far between to permit general statements to be made on the methods used in translating legal documents or on the evolution of legal translation.

\section{Corpus Iuris Civilis and its authority during the Middle Ages}

As stated above, Sarcevic explains the use of extremely literal translation techniques by the authoritative status given to legal texts. The inherently normative or authoritative aspect of this kind of text should, according to Sarcevic, have contributed to the trend of strict literal legal translation. If her reasoning is valid, all translations of legal texts done before the twentieth century should, regardless of the period in which the texts were translated or the translational goal of the translator, be either literal or strict literal translations. Since the thirteenth-century 
translation that will be examined in this article is a translation of a text contained in the Corpus Iuris Civilis, the status of this legal compilation during the Middle Ages must now be described.

The Corpus Iuris Civilis was compiled in the Byzantine Empire at the end of the sixth century. It was "rediscovered" by the West at the end of the eleventh century. By the twelfth century, the Corpus was considered in the West to be an auctoritas ${ }^{6}$ in the abstract sense of the word. It was extensively studied and glossed by the Glossator and Post-Glossator Schools. Various glossators compared the Corpus to the Scriptures. It was regarded as sacred and was given almost Biblical authority. ${ }^{7}$ The glossators called the Corpus "sanctio sancta," "sacratissimae leges," and "donum Dei." One glossator writes that the compilation is "a divine precept coming from the mouth of the princes [des préceptes divins exprimés par la bouche des princes; our translation]," that "the Holy Spirit has spoken through them [que l'Esprit Saint a parlé en elles; our translation]," and that the compilers of the Corpus "had received power from God . . . so one could say that the laws were made by God [ont reçu pouvoir de Dieu . . . et qu'on peut donc dire que les lois ont été faites par Dieu; our translation]" (Thireau 1993, 18).

The Corpus Iuris Civilis was considered to be an authoritative text during the Middle Ages. Therefore, if Sarcevic is correct in considering the use of literalness in legal translation to be due to the authoritative status of legal texts, then the various translations made of the Corpus Iuris Civilis during the Middle Ages should all have been strict literal translations or at least literal translations. In order to test Sarcevic's conclusion, I will now analyze the methods and techniques used in translating the Institutes.

\section{Verse translation by Richard d'Annebaut}

In this section, I will analyze certain aspects of a translation of the Institutes that is a cas d'espèce ${ }^{8}$ from thirteenth-century France. It is the verse translation of the Institutes ${ }^{9}$ attributed to Richard d'Annebaut. The translation was finished in 1280 according to its epilogue; it is written in verse, and contains approximately 24,000 lines, including an eighty- 
four-line prologue and a forty-line epilogue presumably written by the translator. We have only one manuscript of this translation, Harley 4477.2, and one incunabulum printed in Paris in 1485 by Antoine Cayllaut. This verse translation has never been edited.

Here I will examine some of the most frequent translation strategies and techniques used by d'Annebaut in order to determine if, regardless of his reasons for translating the Institutes, he translates it literally or extremely literally because of the authoritative status this legal textbook had during the Middle Ages. If this is the case, then Sarcevic's reasoning and conclusions are correct. Three elements of d'Annebaut's translation will be examined: 1 . the prologue and epilogue ${ }_{i} 2$. the use of synonyms to translate certain legal terms; and 3. the translation strategies and techniques used by d'Annebaut in three sections of the Institutes.

\section{Prologue and epilogue $e^{10}$}

D'Annebaut in his prologue does not broach the literal or free translation topoi. He simply states that he will translate the Institutes in verse form (Si les translateray en rime / Ou consonant ou leonine [17-18]). He further states that his translation is done to educate a schoolboy, Bertrand d'Escalphepié, and that he hopes that it will help the boy to learn and understand Latin (A commencier ceste besoigne / Ne met ung enfant de gascogne) Qui m'est ballie a introduyre / Et a ensaigner et a duyre / Et a tenir lay bien soubz pie. / Bertran a nom Deschalphepie / Frere est Raymont qui les se veut. / Se il y veult garder suvent / Il y pourra asses apprendre / Et plus legierement entendre / Le latin quant il le verra / Et trouver ce que il querra. [21-32]). Furthermore, d'Annebaut explains in the epilogue that students will be able to collate the French and Latin ([faire] collation / de françois contre le latin [34-35]), enabling them to understand what their teachers are telling them, which will be all in Latin (ce que les maitres lor diront / Que tout en latin lor lirons [39-40]).

What can be inferred from d'Annebaut's comments? First, by referring to the Latin original, he positions his translation as a service text to the original and to its auctoritas. Secondly, d'Annebaut does not specify in either his prologue or his epilogue why he versifies the Institutes. He 
does state that he translates to help a young man understand the Latin text. From what d'Annebaut writes, it is logical to assume that he translated the text for pedagogical reasons and sees his translation as a pedagogical tool. ${ }^{11}$ In this sense, d'Annebaut can be included in the category that Peter Dembowsky calls service-translator (Dembowsky 1986) - one who brings attention to the dependence of the translation on the original and to its didactic intention. It is therefore probable that d'Annebaut adapted his translation techniques and strategies to the translational goal he claims to pursue, namely, to translate for "a child of Gascogne [un enfant de Gascogne; our translation]." Furthermore, the combination of the versification process imposed on the text and the translational goal pursued by the translator should have resulted in a translation that is far from being strictly literal or literal as defined by Sarcevic because of the metrical and pedagogical constraints the translator imposes on his translation work.

\section{Use of synonyms ${ }^{12}$}

One of the pedagogical strategies favoured by d'Annebaut is the use of synonyms when translating Latin terminology. The first example is the translation of the Latin expression ab intestat, meaning "without a will" (Section 3.1.7). D'Annebaut, in his translation, alternates between using a calque and gallicizing the Latin expression. This ambivalence is partly due to the versification of the text. When a calque facilitates versification without hampering the transfer of content, he uses the Latin expression: Que pour intestat est tenu / Cil dont l'beritage est venu. The same rule applies to gallicizing a term: in the very same section (3.1.7), he translates the Latin by Qu'ilz fut celui certainement / Qui cil mourut sans testament. This translation strategy could confuse the reader; however, it does have the advantage of teaching the reader the Latin equivalent for the French translation and of referring him or her, indirectly, to the auctoritas of the Latin.

Here is another example. Section $33 \mathrm{~d}(4.6 .33 \mathrm{~d})$ states that when a person takes a stipulation from someone else that gives him or her a 
choice between two things (for example, between a slave or an amount of money), and the claimant then asks specifically for one of the things promised, this constitutes an overclaim. This is because the person taking the stipulation no longer has a choice. Section $33 \mathrm{~d}$ then goes on to give some examples of overclaiming.

The first example is as follows: si quis generaliter bominem stipulatus sit et specialiter Stichum petat [having stipulated generally for a slave, he claims Stichus in particular]. D'Annebaut, translates this passage by: Aucun fait que l'en luy promete / Ung serf qui mencion n'est faicte / Ne de son nom ne de son prix / Ne quel mestier il a apris / Mais ung serf tout generalment / Cil demande especialment / Tel comme il le veult avoir / De cestluy devon nous savoir / Qu'il sourdemande apertement. In the first line, we see that d'Annebaut translates stipulatus by que l'en luy promete. However, at the beginning of Section $33 \mathrm{~d}$ he translates stipulatus by convenant. Once again he destabilizes the text by multiplying the number of equivalents for the same Latin word. The third and fourth lines (Ne de son nom ne de son prix / Ne quel mestier il a apris) are an overtranslation, but they do have a certain academic flavour: all good teachers repeat or emphasize what they consider to be the important elements. Furthermore, he does not transfer the Latin name "Stichus"; he simply explains it with the words "his name." Finally, the last two lines (De cestluy devon nous savoir / Qu'il sourdemande apertement) exemplify the rule of law explained in Section 33d. One problem in all versified translation, medieval or modern, arises from metrical constraints. D'Annebaut uses a formula to fill out line 8, for example: De cestluy devon nous savoir. We find throughout his translation other similar formulae: Mes nous devons cecy entendre, Que nous entendons à traiter, L'en doit savoir certainement, De ce devon estre certain, Nous devon savoir cy endroit, Et nous devon ici entendre, L'en doit en verite savoir. Such formulae attract the reader's attention and are one of the characteristics of d'Annebaut's translation. Of course, this formulaic writing is normally a rhetorical habit devoid of meaning. However, in d'Annebaut's case, it authorizes his direct involvement in the text, permitting him to guide his reader. He comes between the source text and the translated text in calling attention to something he finds 
important. Thus, we can hear the voice of the translator changing the register of the text.

The other two examples given in Section $33 \mathrm{~d}$ are aut generaliter vinum stipulatus, specialiter Campanum petat, aut generaliter purpuram stipulatus sit, deinde specialiter Tyriam petat [he stipulates for wine and specifically claims Campanian, or he stipulates for purple and claims Tyrian]. D'Annebaut's translation of this passage is Et autressy est il vrayement / S'il a de sa paine mise / Tant que pourpre luy est promise / Sans nommer le lieu ni la terre / Ou il la convient aller querre / Ne la valeur de la tainture / Cil demande par aventure / Telle de selle ou de sest / Ce est bien sourdemande faite." The first thing that stands out is that he does not translate the reference to wine. He prefers to put all the emphasis on purple dye. The second line (S'il a de sa paine mise) has a connotation that is absent from the Latin, namely, that purple is given only to those who work hard. Also, instead of translating the word Tyrian, he prefers to spell out the meaning and even elaborate on it by explaining to his reader that, when purple is promised to someone without any details as to its origin or its quality, he cannot specify which kind of purple is to be given. The last line (Ce est bien sourdemande faite) repeats the rule of law. Here we can see that d'Annebaut transfers the general idea present in the Latin, but intervenes in the translation in order to explain it more fully to his reader, in keeping with his translational goal.

Analysis of sections 1.1 (introductory paragrapb), 1.1.1 and 4.18.4

I have reproduced the following three short sections of the Institutes in order to give a general idea of d'Annebaut's translation methods and strategies, and to determine if he in fact translates the Latin text literally. The first two sections define the terms Iusticia (justice) and Iuris prudentia (jurisprudence). 
D'ANNEBAUT, FIRST EXCERPT

\begin{tabular}{|c|c|c|}
\hline $\begin{array}{l}\text { Institutes, } 1.1 \text { introductory paragraph } \\
\text { and Section } 1\end{array}$ & & $\begin{array}{l}\text { Richard d'Annebaut - Harley } 4477.2 \\
\text { - folio } 71 \mathrm{r}-72 \mathrm{~V}\end{array}$ \\
\hline $\begin{array}{l}\text { Justice is an unswerving and perpet- } \\
\text { ual determination to acknowledge } \\
\text { all men's rights. } \\
\text { [lusticia est constans et perpetua vol- } \\
\text { untas ius suum cuique tribuens] }\end{array}$ & 25 & $\begin{array}{l}\text { Justice est voulente estable } \\
\text { Voulente ferme et pardurable } \\
\text { Que a chacun sans attendue } \\
\text { Soit sa propre chose rendue }\end{array}$ \\
\hline $\begin{array}{l}\text { 1. Learning in the law entails knowl- } \\
\text { edge of God and man, and the mas- } \\
\text { tery of the difference between } \\
\text { justice and injustice. } \\
\text { [luris prudentia est divinarum atque } \\
\text { humanarum rerum notitia, iusti } \\
\text { atque iniusti scientia.] }\end{array}$ & 30 & $\begin{array}{l}\text { Le sens du droit est sans doubtance } \\
\text { Que homme ait en soy pourvance } \\
\text { De congnoistre comme certaines } \\
\text { Choses divines et humaines } \\
\text { Et de savoir congnoistre adroit } \\
\text { Quel chose est tort et quel droit }\end{array}$ \\
\hline
\end{tabular}

In these two sections, Iusticia is defined as the constant and perpetual desire to give each individual the rights to which he or she is entitled, while iuris prudentia is the science and pbilosopby of law in acquiring the knowledge of things divine and human, and the science of justice and injustice. Both Latin definitions are general, abstract, and philosophical in nature. D'Annebaut succeeds in translating the general idea contained in the Latin. However, his translation of the introductory paragraph puts into concrete form the rule expressed in abstract fashion in the Latin text. Furthermore, the versification process imposed on the text results in a glissement de sens (a semantic shift) by shifting the emphasis to different aspects of the text. D'Annebaut begins by specifying that justice is the stable (estable), steadfast (ferme) and perpetual (pardurable) desire that each person have without delay (sans attendue), his own thing (chose) returned to him. The use by the translator of a synonymous binomial combined with the repetition of the term volente (desire) in line 26 (Volente ferme et pardurable) puts the emphasis on the steadfast quality of the desire. Furthermore, d'Annebaut commits a slight glissement de sens when he translates the Latin ius suum cuique tribunes by Que a chacun sans attendue / Soit sa propre chose rendue. His translation is a concrete rendition of the abstract idea expressed in the Latin. The 
reason for this shift from a theoretical viewpoint to a practical one seems to be the metrical constraints the translator has imposed on himself. A result of this shift is a change in register from a theoretical and philosophical definition in the Latin to a practical definition applied to the practice of law in the Old French. The idea in both languages stays the same ("justice must be rendered"), but the perspective changes.

D'Annebaut's translation of Section 1.1.1 reveals some of the effects of versification on the text. One can see that the translation is more prolix than the original. The original has twelve words while the translation has thirty-four words. By removing the formulaic writing used by $d^{\prime}$ Annebaut in order to respect the rhyme scheme and to draw the reader's attention to aspects that the translator considers important, one can see that d'Annebaut transfers the two elements found in the definition of iuris prudentia:

\section{D'ANNEBAUT, SECOND EXCERPT}

\begin{tabular}{ll}
\hline $\begin{array}{l}\text { luris prudentia est divinarum atque } \\
\text { humanarum rerum notitia, iusti }\end{array}$ & Le sens du droit est sans doubtance \\
atque iniusti scientia. & Que homme ait en soy pourvance \\
& De congnoistre comme certaines \\
Choses divines et humaines \\
Et de savoir congnoistre adroit \\
Quel chose est tort et quel droit
\end{tabular}

Of the thirty-four words in his original translation of this section, twenty-one remain once the formulaic writing is removed - only nine more than the Latin original, which is normal considering that Latin is a very economical language. This simple exercise demonstrates quite clearly that d'Annebaut's translation is far from being a strict or a literal translation of the Latin original. He makes quite an extensive use of formulaic writing in lines 29 (sans doubtance), 30 (Que bomme ait en soy pourvance), 31 (comme certaines) and 33 (congnoistre adroit). The use by $\mathrm{d}^{\prime}$ Annebaut of formulaic writing in this section seems to have two main goals. The first one is to respect metrical constraints; the second is to draw the reader's attention to certain aspects he considers important. 
The last words of line 29 (sans doubtance "without any doubt") draw the reader's attention to something the translator considers important, while lines 30 and 31 repeat the idea that a wise person must know the meaning of the law (Que bomme ait en soy pourvance / De congnoistre comme certaines: "That a man must be sufficiently wise / To know as a fact"). Finally, the last two words in line 33 repeat, once again, the idea that a person must know the law. Here the translator uses the term adroit, which allows him to respect metrical constraints, but at the same time he brings the reader's attention to the idea of law/rights by using the préfixe d'intensité "a" + droit. D'Annebaut's use of formulaic writing authorizes his direct involvement in the text, permitting him to guide his reader. He comes between the source text and the translated text by calling attention to something he finds important in the text. Here, d'Annebaut becomes a teacher.

The last example comes from Title 18 of Book 4, which deals with criminal trials. Section 4 describes the punishment reserved for anyone committing the crimes of adultery, of homosexuality or of the non-violent seduction of an unmarried girl or respectable widow.

\section{D'ANNEBAUT, THIRD EXCERPT}

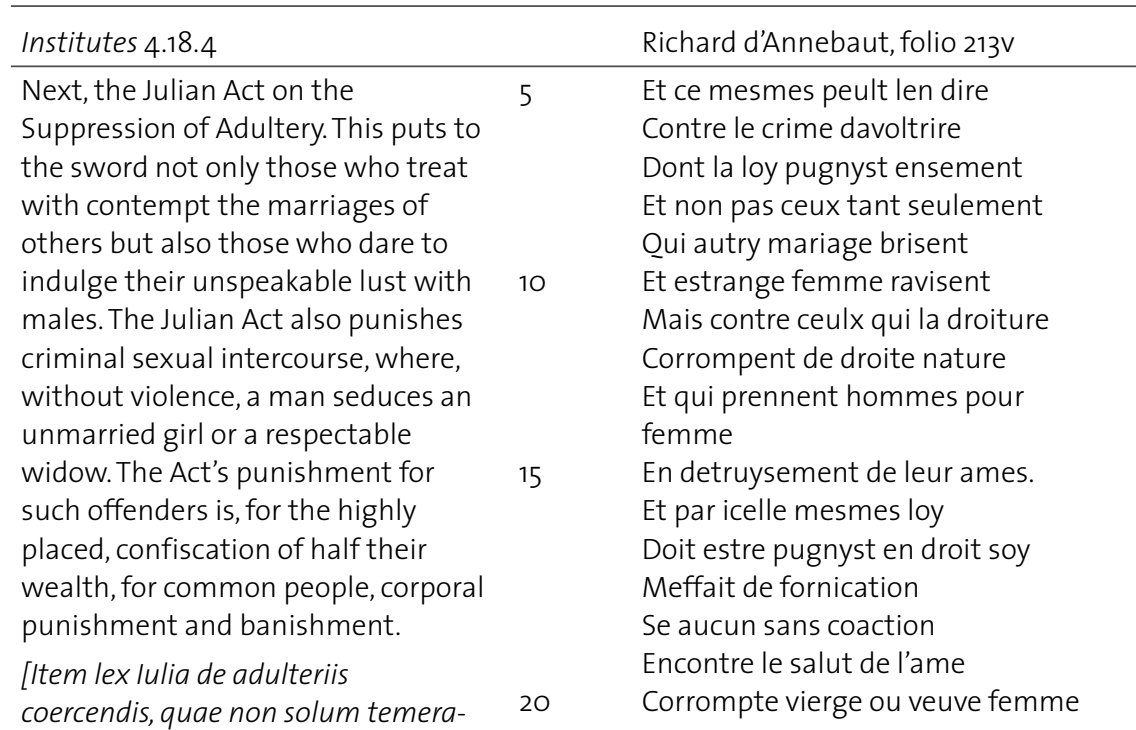


tores alienarum nuptiarum gladio punit, sed etiam eos qui cum masculis infandam libidinem exercere audent. sed eadem lege Iulia etiam stupri flagitium punitur, cum quis sine vi vel virginem vel viduam honeste viventem stupraverit.] poenam autem eadem lex irrogat peccatoribus, si honesti sunt, publicationem partis dimidiae, bonorum, si humiles, corporis coercitionem cum relegatione.
Qui avant quelle fut ravie

Vouloir vivre de honnestre vie.

Tous ceulx qui sy grand meffait font Par celle loy pugniz en sont.

25 Se ilz estoient par verite

En haultesse ou en dignite La moitie de leur bien sans doubte Sera publiee trestoute Se s'estoient personnes petites Qui n'estoient pas de grans merites Par le corps la paine auront Et après en essyl yront.

The first point to note is that, once again, the Old French translation is far more prolix then the Latin original. The former has one hundred and forty-two words, the latter sixty-two. This wordiness is caused by the use of formulaic writing and by the need to respect the rhyme scheme. Lines 19, 25, and 30 are good examples of the effects of versification on the text (Encontre le salut de l'ame / Se ilz estoient par verite / Qui n'estoient pas de grans merites). The second point is that $\mathrm{d}^{\prime}$ Annebaut does not translate the title lex Iulia de adulteriis or the sanction imposed on anyone committing this crime (gladio punit). In both cases, he refers his reader to his translation of the previous section, which gives the title of the law (Julius) and the punishment (Que il en doit mort soustenir). ${ }^{13}$

Lines 8 to 10 refer to the crime of adultery (Et non pas ceux tant seulement / Qui autry mariage brisent / Et estrange femme ravisent). The translation explains that the law will punish those who break another's marriage by ravishing the woman or wife. Here we can see that the translator takes for granted that only a man will commit the crime of adultery! The Latin uses the pronoun quae (qui) in the nominative neutral form, which does not indicate the gender of the adulterer. It is difficult to determine exactly what caused this translation error. D'Annebaut could have used the term person instead of femme. Maybe he was tired or let his belief in the purity of women cloud his judgment. Not all translation mistakes can be explained.

The second crime addressed in Section 4.18 .4 is homosexuality. The Latin defines the crime of homosexuality in this way: qui cum masculis 
infandam libidinem exercere audent [those who dare to indulge their unspeakable lust with males]. D'Annebaut's translation is highly explicit. His translation is Mais contre ceulx qui la droiture / Corrompent de droite nature / Mais qui prennent bommes pour femmes / En destruisement de leur ames. This translation is quite vivid and the imagery used by d'Annebaut leaves absolutely no doubt as to the exact nature of the crime. He specifies that those who take a man as one would a woman will lose their soul. He therefore adds the sense that, homosexuality is not only a crime in secular law but also a crime in the eyes of God. This connotation is not in the Latin text. We can see that d'Annebaut, in this excerpt, intervenes in the text. He explains it and makes sure that there can be no possible misinterpretation by the reader.

The last crime covered in Section 4.18 .4 is the seduction by a man of an unmarried girl or widow. D'Annebaut stays relatively close to the Latin. For example, he translates flagitium (rape, adultery, and so forth) by meffait de fornication (17) and stupraverit (to bring dishonour to, to tarnish) by corrompte (20). However, line 19 (Encontre le salut de l'ame) is an ajout du traducteur. This line rhymes with line 20, which is probably the reason why d'Annebaut added it. It gives a definite moralistic flavour to the translation that is absent from the original. Once again, the voice of the translator is heard in the translation.

\section{Conclusion}

What can be inferred from the various examples? First and foremost, $\mathrm{d}^{\prime}$ Annebaut's translation of the Institutes is not a strict literal or even literal translation of the Latin as defined by Sarcevic. He adds or removes various elements in order to adapt the text to its intended readership. In this sense, by translating the Institutes in Old French and in verse form, he reinvents and appropriates it. He invents a versified legal language in Old French, which forces him to change the register of the text. He usually succeeds in transferring the general meaning of the Latin text, but he changes the formulation and lays greater emphasis on certain aspects. It would appear that for him the transfer of the content of the 
Latin text is not conditional on the transfer into Old French of the linguistic form of the original. The consequences of this action are to adapt the Institutes to verse form, to destabilize the text and to add to its network of meanings.

Secondly, the relation between d'Annebaut, his translation, his readership, and the "author" of the Institutes cannot be characterized as sterile. He intervenes frequently in the text by using various techniques. He guides his reader, reminding him of what he considers important and explaining it when he feels the need. By choosing to versify the Institutes, he destabilizes the text and reinvents it to correspond to his translational goal, which is to educate a child. He has an interventionist approach to translation, which frees him from the Latin text.

On a more general note, it can be inferred from this short analysis of d'Annebaut's translation that the history of legal translation still needs to be written. This specific translation is not a literal or a strict literal translation. However, too little is known about the various translational strategies and techniques used through the ages in translating legal texts to be able to make general statements on the evolution of legal translation. A comprehensive study of the development of legal translation must still be done.

CLAIRE-HÉLÈNE LAVIGNE

University of Ottawa

(Canada)

\section{Notes}

1. These articles are not usually found in translation journals, nor are they written by translation specialists. None of the thirty-nine legal translation articles found in META deals specifically with the history of legal translation.

2. Sarcevic, op. cit., 31-32; Sarcevic at page 25 defines a "strict literal translation" as a translation where "the words of the source text are translated literally into the target language and even the grammatical forms and word 
order of the source text are retained." She defines a "literal translation" as one where "the basic unit of translation is still the word; however, basic transformations (changes in syntax) are permitted to respect the rules of grammar in the target language, thus increasing comprehensibility while following the source text as closely as possible."

3. Legal culture is not an easy concept to define. However, if we define culture as one vast interplay of interpretations of a given social reality (J. Friedman 1994, 73) and if we accept law as a social reality, then legal culture can be understood as the interplay of interpretations of the law at a given point in time and in a given society.

4. A great many articles were written on the prohibition to append commentaries to the Digest. Some examples are the following: Antonio De Robertis, La interpretazione del Corpus iuris in Oriente e in Occidente: approcio comparativo alle posizioni ermeneutiche degli scoliasti bizantini e della glossa di Accursio (Naples: Jovene, 1984); Nicolaas van der Wal, Les commentaires grecs du Code de Justinien, 'sGravenhage: Vitgeverij, Excelsior (1953), Leopold Wenger, Die Quellen des römischen Recbts, Vienna: A. Holzhausen (1953); Adolf Berger, "The Emperor Justinian's Ban upon Commentaries of the Digest," Quarterly Bulletin of the Polish Institute of Art and Sciences in America III, April-June 1945, 656-696 (also published with corrections in BIRD Suppl. Post-Bellum 1948, 124-169); F. Pringsheim, "Justinian's Prohibition of Commentaries to the Digest," Revue internationale des droits de l'Antiquité, IV, 1950, 383-415; Ian Maclean, Interpretation and Meaning in the Renaissance: The Case of Law, Cambridge: Cambridge University Press (1992), 50-59. However, they show little interest in the translation aspect of the prohibition.

5. Note that Sarcevic's overview of the history of legal translation is a mere thirty pages out of a book of more than three hundred pages. Furthermore, her summary spans more than three millennia (1271 BC to the 1990s). In her defence, she does note the scarcity of literature on the subject and the lack of any comprehensive study of the development of legal translation. See her introduction and page 23.

6. The Middle Ages has a theory of paternite de l'oeuvre which was founded on the concept of auctoritas. In order for a text to be considered as an auctoritas, it has to have intrinsic value (it must uphold Christian truth) and it must be authentic (the author must be dead). All the disciplines had their auctores: canon law had the Gratian Decretum, theology had the Bible, and Roman law naturally had the Justinian compilation.

7. Concerning the study of Roman law in the West, legal historians divide the evolution of legal jurisprudence into six large schools of thought: the Glossators and Post-Glossators (twelfth and thirteenth centuries), the Commentators or Bartolistes (fourteenth and fifteenth centuries), the 
Humanists (sixteenth century), the Natural Law School (seventeenth and eighteenth centuries), and finally the Pandectistes (nineteenth century).

8. Richard d'Annebaut does not seem to have been following a fad or fashion when he chose to versify his translation. However, the versification of a legal text originally written in Latin prose is not a common occurrence in thirteenth-century France. All the other translations of the Corpus Iuris Civilis are written in prose. The translation of the Digest is known as La vielle Digeste or Digeste vielle de Justinien en français; it includes twenty-four of the fifty books that make up the Digest. We have three complete manuscripts of this translation and one fragment. The Codex was translated at least once during the thirteenth century. The name of the translation is Code de Justinien, and ten manuscripts of this translation exist today. The Novellae were translated at the end of the century, and two manuscripts of this translation, entitled Authentiques, are known. Only two verse translations of a Latin legal text seem to exist for that century. The first is naturally the translation of the Institutes by Richard d'Annebaut. The second is a translation made by Guillaume Chapu of the Summa de legibus Normannie in curia laicali. It is known as the Grand coutumier de Normandie en vers. Thus, in the thirteenth century there exist only two legal texts translated from Latin prose into French verse: one concerning Roman law and one concerning droit coutumier.

9. The Institutes, a "legal textbook for students," was translated twice in thirteenth-century France. The first translation is outside the scope of this article. It was possibly done between 1220 and 1230. The author is unknown, the text is in prose, and it does not have a prologue or epilogue. It probably represents the earliest translation into Old French of a text from the Corpus Iuris Civilis. It appears to have been quite popular since we know of the existence of twenty-seven manuscripts. Felix Olivier-Martin edited it in 1935. In his introduction, he touches on the questions of the possible identity of the translator, the date of the translation, and the filiations of the various manuscripts. He does not, however, analyze the translation approaches or methods used.

10. In order to simplify the analysis, only the lines that illustrate the techniques used in the translation and the reason why d'Annebaut translated the Institutes are given. The prologue and the epilogue are reproduced here.

11. Verse is seen, during the Middle Ages, as a mnemonic aid.

12. In this article, all English translations of the Institutes are taken from Peter Birks and Grant McLeod's translation; the Latin text is from the Paul Krueger edition.

13. Section 4.18.3 refers to the Julian Act on Treason (lex Julia maiestatis), which states that the punishment for treason is death and the execration of the traitor's memory (cuius poena animae amissionem sustinet, et memoria rei et post mortem damnatur), while Section 4.18.4 refers to the Julian Act on the Suppression of 


\section{D'ANNEBAUT, FOURTH EXCERPT}

1

«Qui de rien ne se veult grever

Il ne pourra pas achever

Chose de quoy honneur li viengne

Il est droit qu'a chacun soutengne

5

10

15

Que hom qui est plain de peresce

N'aura ja los de grant prouesse

Et qui voulontiers ne travaille

Ja ne fera chose qui vaille

Ne de quoy il soit honnoure

Jay par peresse demoure

Trop longuement a commencer

Institutes romancier

Or ny mettray plus de delay

Ore que jay propose lay

Que maintenant la main n'y mette

Et que je ne m'en entremette

Si les translateray en rime

Ou consonant ou leonine

Si ainsi Dieux m'en donne grace

20

De vivre tant que je parface.
[A commencier ceste besoigne

Ne met ung enfant de gascogne

Qui m'est ballie a introduyre

Et a ensaigner et a duyre

Et a tenir lay bien soubz pie.

Bertran a nom Deschalphepie

Frere est Raymont qui les se veut.

Se il y veult garder suvent

Il y pourra asses aprendre

Et plus legierement entendre

Le latin quant il le verra

Et trouver ce que il querra.

Jay grant paour des envieux

Qui sont mauvais et ennuyeux

Et de meffiance ne se faignent

Qu'i ne me blasment et repraignent.

Mais je pri les autres pour dieu

Si je mespren en aucun lieu

Que malvais louyer ne m'en rendent
Et que courtoisement l'amendent]

Adultery (lex Iulia de adulteriis coercendis), which simply explains that the punishment for this crime is death by sword (gladio punit). Here the translator simplifies the text and adapts certain elements.

\section{References}

Primary sources

Les 4 livres d'institutes de Justinian en vers. British Library, Harleian Collection, 4477.2.

Justinian. (1955). Imperatoris Iustiani Institutionum. Libri Quatuor, with commentary and excursus by J. B. Moyle. London: Oxford University Press. 
Justinian. (1997). Justinian's Institutes. English translation with an introduction by Peter Birks and Grant McLeod, with the Latin text of Paul Krueger. London: Duckworth.

\section{Secondary sources}

Dembowsky, Peter F. (1986). "Learned Latin Treatises in French: Inspiration, Plagiarism and Translation." Viator, 17, 255-266.

. (1987). "Scientific Translation and Translators' Glossing in Four Medieval French Translators." In Translation Theory and Practice in the Middle Ages, ed. Jeanette Beer. Kalamazoo, MI: Western Michigan University, 113134.

Kuttner, S. (1982). "The Revival of Jurisprudence." In Renaissance and Renewal in the Twelfth Century, eds. R. Benson and G. Constable. Cambridge: Harvard University Press, 299-323.

Minnis, A. J. (1988). Medieval Theory of Authorship. Scholastic Literary Attitudes in the Later Middle Ages. 2nd ed. Aldershot: Scholar Press.

- and Scoot, A. Brian, eds. (1988). Medieval Literary Theory and Criticism, c. 1100-c. 1375. Oxford: Clarendon Press at Oxford University Press.

Sarcevic, Suzanne. (1997). New Approacb to Legal Translation. Boston: Kluwer Law International.

Stein, Peter. (1999). Roman Law in European History. Cambridge: Cambridge University Press.

Thireau, Jean-Louis. (1993). "La doctrine civiliste avant le Code civil." In La doctrine civiliste. CURAP et CHDRIP Paris: PUF, 13-51. 


\title{
The Role of Translation in History
}

\author{
The Case of Malraux
}

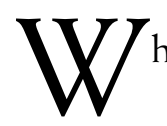

hoever writes history may well control it.

Indeed, this is the desperation in historiography: whoever records the present may control the past and hence the future as well. How can we learn from history when the records have been falsified? Or erased? Especially when or where historiography as the West extols it is moot? The case of André Malraux (1900-1976) suggests that belles lettres, rather than historiography, may preserve more reliable insights. Further, his translators, who expanded his reading audience, have kept the record accessible.

Malraux's China novels were read as fictionalized reportage (or even self-glorifying fictionalized autobiography) at the time of publication. As such, they competed then with more overt journalism and political commentary. ${ }^{1}$ Now at least two of them — Les Conquérants (1928, "The Conquerors," translated by Winifred Stephens Whale in 1929 and Stephen Becker in 1976) and La Condition bumaine (1933, "Man's Fate," as translated by Haakon M. Chevalier in 1934 and "Storm in Shanghai" as 
rendered by Alastair MacDonald, also in 1934) — can be read as history. $^{2}$ If we may take library holdings as a sampling, these novels are read in translation as much as in French. ${ }^{3}$ Hence, translators as intermediaries have a major role in revealing the ultimately self-destructive colonial attitude. (I shall limit my remarks to the English translations.)

The day may perhaps come when Saigon, Canton, and Hong Kong, political flashpoints where the French colonial presence was waning in the 1920s and 1930s, are fully documented in the purest Leopold von Ranke tradition. In the meantime, as we wait for the unlikely apotheosis of neutral historiography, these Malraux novels let us enter the eerie hurricane eye of a society which was itself a doomed "meanwhile." If the subtexts in them had been perceived, could some of the subsequent events, which seem like the inescapable dynamics of humankind, have been prevented? or ameliorated? Moot questions. Leo Trotsky claimed in an essay for the Nouvelle Revue française, February 9, 1931, that the insights came not from Malraux but from the unfolding of events "à l'insu de l'auteur et témoignent contre lui" ("of which the author is unaware and which are testifying against him"). ${ }^{4}$

In any event, the record is here for us to read and adumbrate in French and English. Of course, we cannot read these novels over seventy-five years later with the socio-psychological lenses of their contemporaries, nor should we. In the meantime, we have read other records of the collapse of the colonial empires. With the sites just mentioned: Saigon - as an American of my generation, I followed with protest the war in Vietnam as I witness now its subsequent recolonization. With Canton, now Guangzhou, we tried to gauge the upheavals of China that came after Chiang Kai-shek. With Hong Kong, we watched as the British lease expired. Yet, I should advance, the seed of all these developments could have been inferred from these two novels where any victory, even off-camera, is pyrrhic.

These novels received accolades that guaranteed their translations by talented and conscientious translators. Les Conquérants, a commercial success, occasioned a public debate sponsored by the Union pour la vérité, ${ }^{5}$ and La Condition bumaine was the unanimous jury choice for the 
Prix Goncourt. Critics as politically divergent as Leo Trotsky and Edmund Wilson went into print with their opinions. I would like to examine some typical instances where the translators transmit Malraux's clairvoyance. Textual comparisons make for a Benjaminian reading: the translations, even when they present slight omissions or infelicities, add to the texts.

Both novels rely on firsthand experience. The characters usually had real-life prototypes and interact with historical personages whom, however, Malraux cagily keeps offstage. The fictional characters choose either to engage or evade socially momentous situations. Both novels take up early events of the Kuomintang (Chinese Nationalist Party founded by Sun Yat-sen and taken over by Chiang Kai-shek). The Conquerors follows the 1925 strikes in Shanghai, Canton (Guangzhou), and Hong Kong, from May through August. (Sun Yat-sen had died in March.) It ends with an upturn of Bolshevik ascendancy under Mikhail Markovich Borodin (1884-1951, also known as Michael Grussenberg, Gruzenberg, Grossenberg) and the departure for Europe of Garine, a professional revolutionary of anarchist leanings, whom the first-person narrator has been accompanying. Man's Fate follows Chiang Kai-shek's consolidation of China in 1926-1927 from the perspective of the leftists whom the Comintern sacrifices to the realpolitik of the moment. (Among the few to escape these Chiang Kai-shek executions were Cho En-lai and Mao Tse-tung.)

The Conquerors is a first-person narrative, presumably by a journalist, who, partly because of his fluency in Cantonese, joins the entourage of Garine, the chief protagonist. Part One, the "Approaches," coordinates the geographical and political ${ }_{i}$ that is, as the journalist begins his investigation from Saigon, he comes closer to the real sources of action. In Part Two, "Powers," the narrator joins the entourage of Garine and becomes enmeshed in the intricacies of the power struggle. Whatever the genuine problems of the native population, the novel is concerned only with the individuals involved in the intrigues and the shifting alliances. The families of the foreign missions leave Canton, so it is reported, and the section ends with the announcement that Robert 
Norman, an American lawyer with the Cantonese government, has left. This means that henceforth Russians will be in charge of all military operations. Part Three, "The Man" [Garine], begins with the announcement that the British in Hong Kong have broken the strike with manpower from Japan and French Indochina. Garine is outmaneuvered by Borodin, partly because of policy, partly because of his own physical disability. Despite his confession to the narrator that there have been moments in his life when he has felt pity, the reader's last glimpse is a scene of gratuitous brutality. The approaching commotion of the Red army coming in for what will be a short-lived triumph rocks the room as Garine embraces the narrator in the final brief paragraph.

What stands out when the novel is read now is the colonial mentality. In its most benign form it is a complacent, kindly view of the "natives" as other. In the second paragraph of Part Two, the narrator is going by motor boat just past the Shameen (European section of Canton). He is entranced by an alien setting:

A l'avant, des femmes presque toutes âgées cuisent sur des trépieds, dans une intense odeur de graisse brûlée; souvent, derrière elles, apparaît un chat, une cage ou un singe enchaîné. Les enfants nus et jaunes passent de l'un à l'autre, faisant sauter comme un plumeau plat la frange unique de leurs cheveux, plus légers et plus animés que les chats malgré leurs ventres en poire de mangeurs de riz. Les tout-petits dorment, paquets dans un linge noir accroché au dos des mères. La lumière frisante du soleil joue autour des arêtes des sampans et détache violemment de leur fond brun des blouses et les pantalons des femmes, taches bleues, et les enfants grimpés sur les toits, taches jaunes. Sur le quai, le profil dentelé des maisons américaines et des maisons chinoises; au-dessus, le ciel sans couleur à force de lumière, et partout, légère comme une mousse, sur les sampans, sur les maisons, sur l'eau, cette lumière, dans laquelle nous pénétrons comme dans un brouillard incandescent. $(163-164)$ 
Whale stays rather close:

In the bows [of the sampans] are women [no indication of age] cooking food on tripods giving forth [he removes an ellipsis] a strong smell of burning fat; behind them frequently a cat, a cage, or a chained monkey. Flitting from one to the other are the children, yellow little naked bodies [less rhythmic than jaunes et nus], shaking their fringes of straight hair, more lively and animated than the cats though their little stomachs are bulging [less metaphoric than "pearshaped"] with nothing but rice. The babies, bundles of black linen [linge is not necessarily "linen"] tied to their mothers' backs, are asleep. The golden sunshine [frisante, perhaps untranslatable, suggests "encroaching," but it has no colour denotations] playing around the sampan awnings makes the women's blouses and trousers stand out boldly in blue patches against the brown background, while the children climbing on the roofs look like yellow dots. On the quay the irregular line of American and Chinese houses; above, the sky, colorless in the dazzling brightness; and everywhere, over sampans, houses, water, light as froth, the gleaming sunshine into which we sail as into a mist. (66)

Becker's version is smoother and perhaps more touristic ${ }_{i}$ perhaps as a result, more postcolonial:

On their bows [of the sampans], some women, almost all of them old, are cooking over tripods that smell of hot pungent fat ["pungent" sounds delicious]; behind many of the women sits a cat, a chicken coop [information added], or a chained monkey. Naked, yellow children scamper from one attraction to another ["scamper" is more appealing than "ran back and forth"], their characteristic bangs flying like whisks, more graceful and lively than the cats [instead of "lighter and quicker"] in spite of their round, rice-eaters bellies [instead of "their stomachs, pear-shaped from their rice diet"; does Becker sense malnutrition?]. The infants sleep, little parcels 
wrapped in black cloth hung on their mothers' backs. Glowing sunlight plays on the sampans' awnings, accenting the women's shirts and trousers, blue swatches, and the children on the roofs, yellow swatches. [The brown background provided by the sampans has been erased.] Along the waterfront, the irregular skyline of Chinese and American business houses [information added]; above, a sky bleached pale [a Westerner's disorientation is emphasized] by the intense sunlight; and everywhere that same light, fragile as froth, lying on the sampans, houses, river, an incandescent fog as we knife through. (57)

In its more vicious form the colonial mentality is shown in the treatment of non-Europeans as objects. In the next to last scene of the novel, Garine kills a Chinese prisoner whose information would no longer be valuable:

Une fois de plus je dis au Chinois de répondre. Il fait un geste d'impuissance. La détonation. Le corps du Chinois ne bouge pas; sur son visage, une expression intense de stupéfaction. Nicolaïeff a sauté et s'appuie au mur. Est-il blessé? Une seconde . . . Deux . . . Le Chinois s'effondre, mou, les jambes à demi pliées.

Et le sang commence à couler. (263)

Whale is interpretive, making the situation clearer:

Once again I tell the Chinese to reply. He signifies that he cannot. [A somewhat awkward interpretation.]

The bullet is fired [an explanation, rather than the effect]. The body of the Chinese stands rigid, a dazed expression [intensity is gone] on his face. Nicolaieff has started; he leans against the wall. Is the prisoner [more explicitness helpful since Nicolaieff had jumped] wounded?

One second ... two. The man drops loosely [instead of "goes slack"], his legs half bent; and his [specificity] blood begins to flow. (167) 
Becker is closer to Malraux's camera:

Again I tell the Chinese to answer. He gestures helplessly.

The shot explodes [an explosion can be seen; a detonation is heard]. The Chinese does not budge [humanizing "the body of the Chinese" $]_{i}$ on his face is a look of intense astonishment. Nicolaieff jumps in his chair, and leans against the wall. Is the prisoner hurt [clarification of the injured, since Nicolaieff had jumped]?

A second shot ... two ... The Chinese collapses, inert, legs askew ["buckled" would have been the technical choice]. And the blood begins to flow. (168-169)

Throughout, both translators' choices mute the narrator's objectification of the Chinese.

Since Garine is a dying man soon to set out for Norway, it might be assumed that justice will prevail after the novel ends. But Malraux's narrative voice has prepared us to admire this flawed revolutionary of dubious commitments who believes only in momentary and limited fraternity. Readers can see, at least after the fact, that the Chinese whose consciousness have been raised remain raw material for the clash of egos in geopolitical power plays. As Trotsky notes regarding La Condition bumaine, Malraux's evidence testifies against the narrator's bias.

Certainly, Man's Fate and Storm in Shanghai ("La Condition humaine" translates literally as "the human condition") shows a more cynical overall assessment and in the hindsight of history is even more pessimistic. As in The Conquerors, Malraux provides precise time indications. Six of the seven parts of the novel take place, March 21-April 12, 1927, in Shanghai, Part Seven catches up in July with characters who have escaped to Kobe and Paris. Readers in 1933 might have assumed that somehow justice would prevail, readers from, say, 1936 to the present have known that the situation became catastrophic and only partially and intermittently ameliorated.

Malraux as cineaste moves quickly from scene to scene, with characters' thoughts exposed as if in voice-over or through dialogues. There is 
constant action with success dependent upon luck and timing. The hourly indicators help a reader integrate sometimes nearly simultaneous occurrences.

The camera, however, is never neutral. Its focus is influenced by the emotional state of the consciousness it is in. It sees only what the emotional state of that consciousness is able to take in and in the order in which it classifies perceptions. In the opening scene Ch'en, the terrorist, goes into a paroxysm of fear due to the mewing of a cat in a hotel room window.

Et à côté d'elle [une tache de sang], grandissant comme elle, parut l'ombre de deux oreilles pointues.

La porte était proche, le balcon plus éloigné: mais c'était du balcon que venait l'ombre. Bien que Tchen ne crût pas aux génies, il était paralysé, incapable de se retourner. Il sursauta: un miaulement. A demi délivré, il osa regarder. C'était un chat de gouttière qui entrait par la fenêtre sur ses pattes silencieuses, les yeux fixés sur lui. Une rage forcenée secouait Tchen à mesure qu'avançait l'ombre ${ }_{i}$ rien de vivant ne devait se glisser dans la farouche région où il était jeté; ce qui l'avait vu tenir ce couteau l'empêchait de remonter chez les hommes. Il ouvrit le rasoir, fit un pas en avant: l'animal s'enfuit par le balcon. Tchen se trouva en face de Shanghaï. (514)

Chevalier, the American translator, is exact and eloquent:

And beside it [the blood of the man just fatally stabbed], growing too, appeared the shadow of two pointed ears. The door was at a distance, the balcony was nearer; but it was from the balcony that the shadow loomed. Although Ch'en did not believe in spirits, he was paralyzed, unable to turn round. He jumped mewing! Half relieved, he dared to look. It was an alley-cat. Its eyes riveted on him, it stalked through the window on noiseless paws. As the shadow advanced, an uncontrollable [forcenée has more affect than 
"uncontrollable," perhaps "fanatical"] rage shook Ch'en — not against the creature itself, [insertion of qualifying kindness not found in the text] but against its presence. Nothing living must venture into the wild region where he was thrown: whatever had seen him hold this dagger prevented him from returning to the world of men. He opened his razor, took a step forward: the creature fled by way of the balcony. Ch'en pursued it ... He found himself suddenly facing Shanghai. (14)

MacDonald, the British translator, renders it thus:

And next to it, becoming larger too as it [apparently referring back to the blood] became larger, he saw the shadow of two pointed ears.

The door was a good way off, the balcony closer; but it was from the balcony that shadows came. Although Chen did not believe in evil [a genie is not necessarily evil] spirits he stood rooted where he was. Something miaowed; he gave a start. Halfway to deliverance, he now dared to look. A gutter cat glided in front of the balcony on silent pads, its eyes fixed on him. A furious rage shook Chen as this shadow advanced towards him, anger not against the animal itself but against its presence here; nothing that had life ought to enter this strange region into which he had sunk; this thing that had observed him knife in hand barred the way to his return to reality. He opened the razor, took a step forward; the creature fled through the window. Chen dashed after it - and found himself face to face with Shanghaï. (5)

My preference here, probably subjective, is for Chevalier's translation. Part One covers the period from midnight to five a.m., March 21. Here the chief protagonists are introduced as they mobilize for a sustained insurrection either the next day or the day after. We have just seen $\mathrm{Ch}$ 'en killing an arms dealer to get the bill of lading. Following 
abortive riots in February, a professional revolutionary, Kyo Gisors, half-French and half-Japanese, has been charged by the Communist Central Committee with the coordination of all the factions. Part Two goes from eleven a.m., March 21 to four p.m, March 22. The chances for a successful outbreak look good to Kyo and Katov, his Russian second-in-command. The government's armored train has been sabotaged. Their own forces are marching on Shanghai. Yet as the day veritably explodes, it is clear that the Central Committee has allowed the Kuomintang to take over the "revolution." At almost the exact halfway point of the novel, Malraux stages one of his signature climaxes. Kyo, Katov, and $\mathrm{Ch}^{\prime}$ en have just received a request from a Kuomintang officer to share arms. They hear a distant rumble (la rumeur, an insidious noise of human origin, English "rumour"), "but so confused (confus, 'blurred' or 'muddled') that they had to strain their ears in order to make out what it was."

Il semblait qu'elle montait de la terre. . . .

Mais les cris approchaient comme s'ils fussent venus de la banlieue vers le centre. De plus en plus forts. Impossible de distinguer les paroles. ... .

Les cris, toujours sans paroles, devenaient de plus en plus proches, comme si quelque nouvelle capitale eût été transmise de foule en foule. Luttant avec eux, un autre bruit se fit place, devint enfin distinct: l'ébranlement régulier du sol sous les pas. (604)

Chevalier:

It seemed to rise from the earth . . . the cries seeming to come from the outskirts towards the center. Louder and louder. Impossible to make out any words. . . .

The shouts, still indistinguishable, were coming closer and closer, as though capital news were being passed from crowd to crowd. Vying with them, another sound was making itself heard, and finally 
became distinct: the rhythmic beating (a little weak for l'ébranlement, "quaking") of footsteps on the ground. (135)

\section{MacDonald:}

It seemed to rise out of the ground. . . . The shouts seemed to be coming in towards the centre of the city, from the suburbs. Louder and louder. It was impossible to catch any words ...

The shouting, still unintelligible, came nearer and nearer, as if some news of vital importance were being passed along from one crowd to another. But another noise struggled to make itself heard, succeeded, and at last grew distinct: the regular tramp of marching men was shaking the ground. (131)

The footsteps changed direction towards the armored train. Then the men in the train must have decided to go down firing:

Le train même entrait dans une transe furieuse. Tirant toujours de partout, ébranlé par sa frénésie même, il semblait vouloir s'arracher de ses rails, comme si la rage désespérée des hommes qu'il abritait eût passé dans cette armure prisonnière et qui se débattait elle aussi ... c'était le frémissement des rails qui maintenaient tous ces hurlements ainsi qu'une camisole de force. . . . Trente secondes, le fracas cessa. Au-dessus de l'ébranlement sourd des pas et du tic-tac de toutes les horloges de la boutique, s'établit un grondement de lourde ferraille: l'artillerie de l'armée révolutionnaire. (605)

Chevalier follows suit:

The train was working itself into a frenzy ... it seemed to want to tear itself from its rails as if the desperate rage of the men it sheltered had passed into the imprisoned armor, which was also struggling. . . . it was the quivering of the rails which resisted all those roars [omit- 
ted in English: comme une camisole de force "like a straight-jacket"] . . . Thirty seconds, and the uproar ceased. Above the dull reverberations of the footsteps and the tictac of all the clocks in the shop, a rumble [le grondement, also "thundering"] of heavy iron became dominant [s'établit "took over"]: the artillery of the revolutionary army. $(136-137)$

\section{MacDonald:}

The train itself appeared panic-stricken. Firing continuously from every aperture, shaking itself violently in its frenzy, it seemed to be trying to wrench itself from the rails, as if the hopeless rage of the men whom it sheltered had infected the armour which imprisoned them, so that it, too, was struggling for freedom. . . . the shuddering of the rails which held all these screaming wretches fast, like a straitjacket:. . . thirty seconds later the din ceased. Through the dull vibrations of the marching feet and the ticking of all the clocks in the shop, a creaking of massive metal made itself heard: the artillery of the revolutionary army. (132)

MacDonald makes no mistranslation per se, and his use of English is a matter of taste.

In the remainder of the novel, Malraux continues to imagine history from the inside. Part Three, March 27 (in translation; March 29 in French), Kyo goes to Hangkow to try to persuade the Central Committee, none of whom is Chinese, to resist the Kuomintang. He is aware that Ch'en, obsessed with assassinating Chiang Kai-shek, is in Hangkow as well. Part Four, the longest of the novel, goes from noon, April 11 to five a.m. April 12. Kyo is alerted through various connections that he will be liquidated if he does not flee, and Ch'en fails in his plot to destroy Chiang Kai-shek with hand grenades; the Generalissimo was not in the car. Ch'en finishes himself off with a revolver in his shirt pocket (a grenade has destroyed his legs) as the 
section ends. Part Five picks up immediately with competing rumours about the assassination. In these six hours the featured characters are arrested, dead, or on the run as the Kuomintang begins to wipe out the opposition. Part Six, beginning five hours later, goes until six p.m. the following day when Kyo takes cyanide after interrogation, and Katow, having given his cyanide to two young prisoners, is taken off to be killed in a train locomotive. Part Seven is the aftermath, three months later; the supporting characters, especially the foreigners, have retreated to safer spots in the world: Kobe and Paris.

Readers of the English translations - both Whale's and Becker's The Conquerors, Chevalier's Man's Fate, and MacDonald's Storm in Shangbai had at the time the option of thinking that Westerners still looked good in this cultural clash. Americans, whose Protestant missionaries had presumably established a solid educational base, could even be smug. (Ch'en - like Chiang Kai-shek by his second marriage - is a Methodist.) Did the translations allow them to be smug? If they wished. Becker's translation of The Conquerors, published the year of Malraux's death heightens, albeit subtly, the postcolonial superiority to which Trotsky had objected (303).

The Chinese whose consciousness had been raised remained raw material for the clash of egos in the geopolitical power plays of Russia and capitalism - American, European, and Japanese. The megalomania of Chiang Kai-shek can be inferred, the institutionalized solipsism of the Westerners is blatant. (Malraux misses only the imminent danger of the Japanese.)

The pre-Existentialist reading which these novels elicited after World War II is still valid, but now we can see these exposures of heroism and altruism contaminated by an imperialist egotism and opportunism. The outsiders die bravely but intervene grievously. The abortive revolutions that Malraux animates in fiction make subsequent mainland Chinese history — to the extent we know it — comprehensible. Our reading has changed, and the English translators have helped us, forcing us to analyze the French more closely. 
The translations still read as though freshly made. The translators, their task completed long ago, constructed an afterlife where the colonial mentality, while perhaps muted, can clearly be inferred.

MARILYN GADDIS ROSE State University of New York at Binghamton (U.S.A.)

\section{Notes}

1. Whale's translation was published in 1929 by Cowle Books (New York) and Jonathan Cape (London); Becker's in 1976. According to World Cat, March 9, 2004, 326 copies of Whale's translation may be found in libraries; 809 copies of Becker's in libraries in editions by Holt, Rinehart and Winston, University of Chicago, and Grove Press. According to World Cat, March 29, 2004, 1,827 copies of Chevalier's translation Man's Fate (1934, copyright renewed, 1961) are in libraries; 312 copies of MacDonald's Storm in Shanghai. All citations are from the first editions. French citations are from Oeuvres complètes (Paris: Gallimard NRF, 1989).

2. Serious establishment commentators ignored the novels altogether. The Revue des deux mondes had consistent commentaries during 1929-1930. These take up the actions of the chief Russian organizer Mikhail Markovitch Borodin, but do not mention Malraux. See, for example, Henri Lormian 1930; also "La Politique coloniale et le Bolchévisme" 1930. Incidentally, Lydia Holubnychy 1979 makes no mention of Malraux. Dan N. Jacobs thinks Garine may echo Borodin's remarks (Jacobs 1981, 153).

3. To tell the truth, in the library catalogs consulted, these books were on the shelves!

4. Trans. Madeleine Etard, no. 211, 1931; reprinted in Malraux 1989, 302.

5. Proceedings in Variétés, 6, 15 octobre 1929; reprinted in Malraux 1989,1, 287-294.

\section{References}

Angoulvant, G. (1930). "Les Réformes en Indochine," Revue des deux mondes (Sept.-Oct.), 902-917.

Becker, Stephen. (1976). The Conquerors. New York: Holt, Rinehart and Winston. 
Chevalier, Haakon M. (1934). Man's Fate. New York: Random House [1961]. . (1940). "André Malraux: the Return of the Hero," Kenyon Review, 2 (Winter), 25-46.

Galante, Pierre. (1971). Malraux, trans. Haakon Chevalier. New York: Cowles Book Company.

Holubnychy, Lydia. (1979). Michael Borodin and the Chinese Revolution, 1923-25. New York: East Asian Institute, Columbia University.

Jacobs, Dan N. (1981). Borodin, Stalin's Man in China. Cambridge: MA. Harvard. Lacouture, Jean. (1975). André Malraux, trans. Alan Sheridan. New York: Pantheon.

"La politique coloniale et le Bolchévisme." (1930). Revue des deux mondes (May-June), 241-262.

Lormian, Henri. (1930). "La Question chinoise." Revue des deux mondes (March-April), 69-92.

MacDonald, Alastair. (1934). Storm in Shanghaï. London: Methuen.

Malraux, André. (1989). Oeuvres complètes, ed. Pierre Brunel. Paris: Gallimard NRF.

Trotsky, Leo. (1931). "La Révolution étranglée," trans. Madeleine Etard. La Nouvelle Revue française, 211 (April 1); reprinted in Malraux (1989), 302-307.

Whale, Winifred Stephens. (1929). [1967]. The Conquerors. Boston: Beacon Press. 
This page intentionally left blank 


\section{Puritan Translations in Israel Rewriting a History of Translation}

\section{Introduction}

$\mathrm{T}$ his essay is an attempt to review the history of translation in Israel, with special focus on the ideological norms that permeated it and on the function of (moral) censorship as a tool for shaping and delimiting culture.

The traditional history of Hebrew translation, as summarized in the Hebrew Encyclopaedia entry "Translation" (Toury 1980, 1063-1065), presented the progress of translation as an integral part of the revival of the Hebrew language, petrified by centuries of relying on written canonical sources only. It emphasized the vital role of translation in this revival, the different ways in which the translation laboratory renewed, adapted and/or invented vocabulary; it noted remnants of the petrifaction in the twentieth century, with the written language still maintaining its normative supremacy in translation, in spite of the growing translatability between Hebrew and European languages.

On the basis of recent research, I would like to offer not a contradictory view, but one that would allow for some self-contradictory aspects 
of this complex process of language/culture building. It will shed some light on the role of puritan Zionist ideology in this revival, a role that eventually undermined it. Suppression of the erotic repertoire will be used to illustrate the point.

Two remarks before I proceed: the first concerns terms like obscene, pornographic, erotic. This essay will not use evaluative / aesthetic definitions of pornography; it will rather adopt a functionalistic attitude to pornography (Loth 1961, 8), regarding it as anything so defined by official or influential groups, that is, writings about sex or eliminative functions which past or present officials or influential groups have suppressed (or tried to) on the ground that they were morally corrupting or degrading. Loth adds that this definition includes virtually all literature dealing with sex except the technical and scientific, and even some of that, too $\mathrm{I}$ include the latter as an integral part of my work. Adopting this (non-) definition is in accordance with the fact that, in the post-Foucault era, it has become impossible to view sexuality within the cultural context without considering its role in the politics of power, and that moral censorship, like any other censorship, is regarded as a cultural vehicle for defining notions of the self and delimiting the other (Greenblatt 1992, 121; Wolf 2002, 45).

The second remark concerns the risk of generalization: this being a brief summary of part of my research on the subversion of literary translation, it cannot include details or nuances and thus risks generalizations. My forthcoming book on Sabra Puritanism: Suppression of the Erotic in Hebrew Literature from the Thirties to the Eighties will offer a more diversified overview and analysis.

\section{The new Hebrew}

In very early stages of its revival, in the late eighteenth century, Hebrew literature acknowledged the importance of translation as the basis for any new cultural infrastructure. This tendency was enhanced with the first immigration waves to Israel, around 1880, where a new local cultural structure had to be established from the ground up. In 1930-1940, 
respectable publishers such as Mitzpeh, Stiebel and Omanut were already so translation-oriented, that Hebrew writers raised voices of protest (Shavit 1998; Toury 1977, 123). Yet these publishers pre-selected either classical or socialistic-realistic material for translation. Love and sex were considered irrelevant to the national agenda, if not altogether depraved. This tendency was intensified when publishing houses of socialistic ideologies began to take over in the forties and fifties with names such as Sifriyat-Poalim (Workers' Library), Am Oved (Working People), or Sifriya-La'am (People's Library). The latter helped maintain a puritanical approach to literature that dominated Israeli culture well into the 1970s and even the 1980s.

Although Judaism is far from preaching abstinence or asceticism, puritanical attitudes have some roots in Hebrew culture. Historically speaking there have always been sects or individuals who preached partial if not total sexual abstinence for the sake of "higher" goals, such as absolute dedication to the study of the Torah (Biale 1994, 232). This tendency may have been reinforced in certain communities in Eastern Europe, where child-marriages became the custom, resulting in early and traumatic sexual encounters that may have driven many young men away from their families to join the strictly male entourage gathered around a Rabbi or a Chassidic Tzadik (Just). Enlightenment brought forth new dilemmas: the old image of the Ghetto Jew had to be replaced with that of the New Jew, later the New Hebrew, tanned, upright, endowed with muscles. The ideal new Hebrew woman was born as well, as reflected in popular novels of the nineteenth century: she was to enjoy a better general education, but her domain was still to be the home (Ben-Ari 1997, 234-241). When she finally emerged from this stage, the new emancipated and enlightened Jewish woman may have evoked admiration in some, but usually a sense of unease and fear: fear of assimilation, for she was free to choose among her peers, Jews or Gentiles, as well as fear of this yet-unknown being - the sexually liberated woman (Feiner 1998, 253-303). 


\section{Victorian puritanism}

Victorian puritanism, which had invaded Europe and America in the nineteenth century, could thus find an echo, if not in an outright dislike of this new erotic liberation, in the dialectic wish to break with old traditions and preserve them simultaneously. Studies of the period, including those accomplished by "victims" such as D. H. Lawrence, later acclaimed as the prophet of sexual liberation, argue that more than any other socio-political circumstance, it was widespread and already inherited syphilis that accounted for the spread of puritanism in the seventeenth and eighteenth centuries (Lawrence 1961 [1929], 60-85). Be this as it may, what is generally agreed upon is that the highest point of puritanism was the Victorian era, nicknamed "The Golden Age of Prudery and the Golden Age of Pornography" (Loth 1961, 117). It was heralded with the 1802 establishment of the "Society for the Suppression of Vice," proceeded with Thomas Bowdler's 1818 expurgated Family Shakespeare and culminated in Chief Justice Cockburn's 1868 notorious obscenity laws. Apart from gaining entry in the dictionary with a new English verb, Bowdler opened the door to cleansing censorship of the classics. Judge Cockburn's historical definition of pornography sealed the ban on books for a hundred years until it was lifted in a series of book trials that echoed throughout the Western world in the 1960s. His definition was so broad it encompassed all material written with the INTENTION of corrupting the minds of those OPEN to such influences and into whose hands such material MAY fall (Greenawalt 1995, 99). It banned countless books such as Cleland's Fanny Hill, D. H. Lawrence's Lady Chatterley's Lover, Joyce's Ulysses, Miller's Tropic of Cancer, Nabokov's Lolita and many more.

Puritanism swept in various versions through most of Europe and America. It was acclaimed in Boston, where the first trial of a book took place as early as 1821 - Cleland's Fanny Hill, of course, which had come to symbolize pornography at its worst. In 1872 the American "Committee (later 'Society') for the Suppression of Vice," with Anthony Comstock at its head, proceeded to impose the puritan norm on all aspects of life, banning books, pamphlets, powders, and contraceptives by the pound. Comstock's name went down in history as well, not only 
as one of the most famous American vicecrusaders, but as one of the few persons outside the legislative system with a law bearing his name (Loth 1961, 144-145).

Puritanism infiltrated Israel, then part of the Ottoman Empire, at the turn of the twentieth century, with the first immigration waves from Europe. The thirty years of British Mandate up to the 1948 establishment of the State enhanced its spread, especially with the introduction of the British Obscenity Laws into Israeli Mandatory Law in 1936, but there it encountered a seemingly different ideology, borrowed from the Bolshevik revolution, that of freedom of sex and equality of the sexes. On the face of it, the promise of freedom and equality was anti-puritanical in principle, but the Bolshevik ideology abolished the erotic and regarded sex and marriage as capitalist bourgeois notions that had to be suppressed if not annihilated. This ideology permeated the early settlers and was to become a major factor in the shaping of the new culture.

Thus, Zionism started with a promise of being, among others, an erotic liberation, and in fact succeeded in maintaining this myth for decades, well after the establishment of the State. The "Woman Question" was one of the key ideological issues discussed in the first stages of this Jewish revolution. Back in 1897, the first Zionist Congress granted women the right to vote, though because of opposition from Orthodox sectors, this right was not implemented in Israel until 1926. In fact, equality for women in the Second Aliyab (second immigration wave, 1904-1914) became mainly the right to labor as hard as men, draining swamps, paving roads, and settling the country. Struggles for separate organizations for women pioneers and workers lagged behind until 1922, when their small faction included six hundred members. In 1934, however, they joined the general workers' union and were duly submerged in it. A small step forward was accomplished in 1936, when pressure on the Mandatory rule resulted in changing the minimum marriage age of girls from nine to fifteen. Another small victory was gained in 1947, with bigamy prohibited by the Mandatory Law. But no pressure helped women in their struggles to withdraw marital laws from the absolute power of the religious Orthodoxy; neither did this happen 
with the establishment of the State. Women, who had joined the radical Zionist movement with the hope of virtual and real gain, found themselves pushed to the side. Zionism had become an essentially "male" movement, removing erotic liberation from the national agenda.

What led to this ideological twist, apart from harsh circumstances and underlying ambivalent feelings towards sexual liberation, had to do more with internal power struggles over reshaping the new Hebrew culture than with adherence to British or Bolshevik norms.

The Jewish revolution had to assume a more "virile" character as it grew more nationalistic. In fact, as Mosse (1985) pointed out, the national movements of the nineteenth and twentieth centuries tended to be predominantly "virile," and this particular movement had to confront accusations such as those of Sigmund Freud or of his followers like Otto Weininger, that Jews were effeminate and neurotic. Growing tension in the 1930s, then impending war with the Arab population in the 1940s, intensified the need for a more virile image of the New Sabra: the Shomer ideal was adopted, that of the Bedouin-like tough, silent Sabra, upright on his horse, ready to sacrifice all for his country and as one with his tough surroundings. Utopian communes advocating the abolishment of old notions of family or couples, such as the settlement of Upper-Bitanya in the Galilee, created much controversy and soon died away, faced with the small number of (reluctant) women and excruciating material hardships - malaria, hunger, lack of work, to name just a few. Yet notions of marriage, family, and children had to be sacrificed for the sake of a better future. Communal education, such as undertaken in the Kibbutz, striving to apply Zionist ideology to everyday life, mobilized all its efforts into creating what Spiro called the "Puritan Sabra" (Spiro 1965): it stripped sex of its mystery with methods of coeducation and cohabitation, and tolerated couples as long as their presence did not interfere with community life. The Freudian slogan of "Sublimation without Repression" was heralded with enthusiasm by youth movements and pedagogues like Shmuel Golan: the sexual urge was natural and creative, and should, by no means, be repressed, but culture decrees that it must be channelled into "higher" goals (Golan 
1941, 24, 61). The new principles of "Sabra purity" were formed, and they were all-encompassing: purity of thoughts, words, and deeds. The tenth commandment of the "Shomer-Tzair" Youth Movement required the Sabra to abstain from smoking and drinking, and to maintain sexual purity. The War of Independence further helped exclude women and sexuality from the cultural scene. War was a man's affair and the woman was a distant image from back home, to long for and dream about. The Palmach youth, the young volunteers preceding the regular army of the State of Israel, was said never to have used foul language and to have regarded sex as impure and unimportant compared with "higher" national values. They were in fact puritanical to such an extent that, as one of its members claimed in her memoirs, ninety-nine percent of the combatants must have died virgins (Ben-Yehuda 1981, 266). When violence ceased to be the dominant issue in the 1950s, it was replaced with the unequivocal demands of the melting-pot ideology. The "erotic revolution" had become utterly irrelevant.

With the massive waves of immigration (especially from Arab countries) between 1948 and 1953, the image of the "other" was firmly established in opposition to the Sabra: the new immigrant, the speaker of Yiddish who refused to promptly sever his ties with the Diaspora; the Oriental Jew who would not give up his past traditions to be remodelled in this radical secular mould. The latter retained an overtly erotic hue, negatively connected with a Levantine culture of cards, cafés, and brothels. Much like the Arab (or rather, his image), the Levantine immigrant was suspected and feared for his sexuality; unlike the Arab, though, he had a rightful claim on whatever female the Sabra considered his own, which made him a bigger menace.

\section{Norms of representation in central literature}

Literature, both original and translated, joined in this ideological indoctrination. Hebrew literature, from its early start in Eastern Europe in the late nineteenth century and up to its rebirth in Israel in the late nineteenth and early twentieth centuries, reflected the 
so-called Oedipal break with the Diaspora and the "Old Jew" image. This break, repeated in later years but still maintaining the periodic sons-against-fathers rebellion, had become a central theme in Israeli literature, with the image of the New Jew, New Hebrew and, later, New Israeli-born Sabra at its very core. Up to the 1970s, Hebrew literature maintained the Zionist, predominantly "male" narrative of the Oedipal break with the fathers' generation. The names these literary trends were given - retrospectively — reflect their ideological involvement: The Meyasdim (Founding Fathers) generation, for instance, broke away from the Diaspora, the Tashacb (1948) generation broke away from the Founding Fathers; the Medina (Israeli born) generation broke away from the 1948 predecessors. By 1973, with the end of massive immigration and the prospect of relative normalization, the Yom Kippur war threw the country (and its culture) into yet another traumatic period of reassessment of national values (Miron 1993). By now the New Sabra protagonist of central Israeli writers like Amos Oz and A. B. Yehoshua had grown old and tired, and his erotic (literary) endeavours, if any, were pathetic, but he and his rebellious rejection of his ancestors were still the focus of attention.

Translated literature could well have introduced changes in this atmosphere of erotic restraint, since it could introduce other, different models of representation without necessarily being criticized for violation of the norm. As modern research has illustrated time and again, translated literature can afford to disobey the norm (and sometimes even the law) with the excuse of being a reflection of "foreign" values or of being too negligible to meddle with. In this case, however, translation chose to join the national mobilization, carefully pre-selecting texts according to their idealistic value, and scanning and manipulating other texts, models, or genres to fit TL norms. It was, however, much more self-censorship than any fear of legal action that motivated cultural "agents" to forfeit the innovative and possibly subversive function of translation in favour of the mainstream doctrine. True, there were the 1936 Mandatory obscenity laws to contend with. They were, in fact, made even stricter in 1965, when the Israeli law decreed that the penalty 
for obscenity should be increased to three years' imprisonment (more than the three-month period in the Mandatory Law, more than the twoyear maximal penalty in British law; see Cohen 1973, 82-86). Yet this seemingly severe attitude applied mainly to the theatre and the cinema, where a pre-censorship committee determined the fate of every single play or movie. With the exception of two or three minor "book trials," literature was spared.

Literature was spared, yet it functioned as if it had been subjected to pre-censorship as well. No attempt was made to publish one of the notorious banned books in a central publishing house, nor was any public outcry raised against this suppression. A small voice of protest was raised in 1966, when the leftist Hebrew writer and journalist Dan Omer published his scandalously pornographic On the Road and went

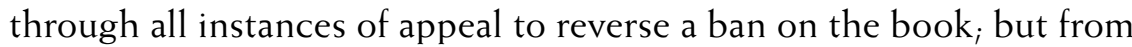
the judge's final verdict it is obvious that Omer's virulent attacks on the Orthodox parties was the underlying reason for the enforcement of the obscenity law in his case. In fact, in 1968 a committee with Judge Vitkon at its head recommended that Israeli obscenity laws be reviewed, in favour of the free development of art, literature, and science, though the recommendations never had any legislative follow-up. Even when the ban on books had been lifted in the Western world, the books were slow to penetrate this self-inflicted puritanism; some were translated in the seventies and eighties, others doomed to oblivion.

\section{Marginal alternatives: pulp fiction and sex guides}

Yet a literary system, like any other cultural system, tends to be stratified, must, indeed, be stratified for fear of stagnation, and erotic literature, too, found an outlet. As is typical of puritan cultures, it was allowed to flourish on the periphery, in three main alternative forms: erotica read in the original source language or in various translations, erotic pulp fiction, and pseudo-scientific sexual texts. It should be noted that the margins were on the one hand the "natural" background for these subversive genres to flourish in, yet on the other hand they were also the right place for 
them to be channelled to. There they could be observed and, if necessary, controlled, and could, no less vitally for culture shapers, be labelled "obscene," "perverted," "dirty." Indeed, the rare public surveys of reading habits done in Israel after 1948 that did enquire about habits of "pulp" readership encountered almost zero results; people were reluctant to admit to such non-normative behaviour.

The option of reading in other languages may appear obvious in an immigration culture, but it opposes cultural shaping, especially in the periods of transition, even more so in view of the significant gap between the generations in such communities. Most newcomers settling in Israel before and after the establishment of the state had access to books in their own languages. In fact, many maintained cultural organs such as newspapers, lending libraries, and theatres in their own tongues. This phenomenon was relatively short-lived, however, for it undermined the melting-pot ideology, and was to be rejected by their more chauvinistic Israeli-born offspring.

The second alternative, that of pulp fiction, was, on the whole, considered "filthy" and "depraved," though this category included both translations of the banned books, in other words, "higher" forms of literature, and (pseudo-) translations of the "lowest" forms of pornography. All were driven under the counter; they came out of cheap printing houses, with minimal investment in production, to be sold at kiosks or newspaper stands. Though there is no precise data as to the scope of this subversive production, it was obviously quite big, with the 1960s apparently the peak of pulp production. Pornographic literature anywhere is hard to trace, and the Hebrew instance was no exception: the books were printed in pirated editions with considerable effort to erase traces leading to writer/editor/publisher. Names of authors/translators were usually fictitious. Printing firms appeared and closed overnight. The books/booklets were printed on cheap paper that did not last long. Even if sales numbers could retrospectively be quoted (Eshed 2002, 234 quotes 5,000 copies of The Captive from Tel Aviv), they would not represent the hand-to-hand distribution scope typical of underground publishing of this sort. 
Yet peripheral and central literary activities were, particularly in this case, strongly linked together: the canon could not have survived without the piratical production in the margin, which slowly began to infiltrate the centre and revitalize it in the 1970 s; while the relatively self-restrained activity in the "black market" cannot be accounted for without its counterpart in the puritan canon. As is often the case, though clashing with mainstream ideology, the minor erotic genres in the margin looked to the canon for legitimization. Moreover, the names of the translators/editors involved in their production reoccur, and study of the persons behind the many pseudonyms confirms that a relatively small group of people was responsible for the production of these (pseudo-) translations. This group consisted of young writers, journalists, army soldiers, and students, who, though aspiring higher, wrote/translated erotica as secondary jobs.

Generally speaking, the translation of the various banned books, later to be acknowledged as modern masterpieces, followed more or less the same course. They first appeared in the 1960s, in cheap pocket editions, with all the characteristics of pulp fiction, including sensational captions and abundant printing errors. At some later point in the 1980s they were retranslated and published in central, respectable publishing houses. There are variations, of course: the expurgated edition of D. H. Lawrence's 1928 Lady Chatterley's Lover appeared in 1938 in the respectable Mitzpeh publishing house. It reappeared in the mid-sixties with the promise of being a complete and unabridged version (a suspicious formula at best), from a marginal publisher, with some of the daring parts censored as well as numerous "poetic" parts. It was then retranslated in 1971, this time fully, by a well-known writer and translator, Aharon Amir, at a central publishing house (Am Oved) in 1987, to crown this canonization process, the same translation reappeared in a hardcover edition.

Not all the banned books received the same degree of canonization. To name but a few: Henry Miller's 1934 Tropic of Cancer, translated in 1964, was retranslated for a more respectable publishing house in 1985 but never enjoyed great popularity. Cleland's Fanny Hill was translated several times, from 1963-1964 through 1999, each version claiming, 
with no justification whatsoever, to be complete and unabridged. Unlike its rehabilitation in England and the US, where some critics compared it to the best eighteenth-century novels such as Fielding's Tom Jones or Defoe's Moll Flanders or even to parodies of novels like Richardson's Pamela, it never managed to rid itself of its notoriety as pornography. Nabokov's Lolita was translated in 1959, a year after the ban had been lifted, in a cheap pocket-book edition, and while it had not been censored (in fact there is no overt sexual language to censor), the translator did not cope with its vast and complex literariness; thus the novel's pornographic character was amplified. It was retranslated only in 1986, in one of the elitist publishing houses, with the full canonizing scientific apparatus: annotations, foreword by the translator, afterword by an academician. Pauline Réage's 1957 Story of $O$ was not translated until 1999, when it appeared by way of a respectable publisher with all the academic apparatus. Some of Guillaume Apollinaire's turn-of-the-century scandalous erotica has been translated only recently by marginal publishers.

The efforts of the banned books to gain legitimization, seemingly paradoxical for pulp fiction, are not at all surprising considering the cultural atmosphere of the 1950s and 60s. These efforts consisted in (a) quoting high recommendations from famous personalities in the source culture, (b) cleansing the book of excessive eroticism, and/or (c) embellishing the language. In the language-embellishment process specific terms for sexual body parts and acts would be euphemized; older, Biblical and Talmudic terms would be used, where slang Hebrew terms would have been used in the spoken vernacular. Slang expressions (such as abound in Henry Miller's novels, for instance) would occasionally and boldly - be replaced with Hebrew equivalents, only to be embedded in a highly correct, normative style, usual for translation. Excessive literariness, however, would not be indulged: outstanding "private" metaphors would be replaced with worn out "safe" clichés or similes.

Pulp pornography did not differ much in that respect. Unlike the eighteenth- and nineteenth-century models in England, for instance, which enriched the literary and lingual repertoires (Peakman 2003), it 
was rather naive in today's terms, much more allusive and "lewd" but less specific in terminology than the banned books. It seemed to look up to higher genres for recognition, disdained slang, and adopted literary (epigonic, needless to say) models of style. Most of the texts/models masqueraded as translations, for this, too, granted them some small prestige (see pseudo-translation in Toury 1995, 40-52). Yiddish models, the damsels-in-distress type such as Regina or Sabina, in imitation of French and German models, enjoyed much popularity with titles like Tamar, Smadar, The Captive from Tel-Aviv and many more. The pulp translation of Fanny Hill inspired dozens of "continuations" such as the 1964 Fanny Hill's Bedroom, or Fanny Hill's Youngest Daugbter, mostly pseudo-translations. A controversial "daring" variation, using Nazi concentration camps as background and excuse for sado-masochistic pulp fiction, was the peak of explicitness in its sexual repertoire, yet as "conservative" as the rest in language. ${ }^{1}$ One trait characterized cheap porn: in terms of the erotic lexicon, the texts were even less brazen than the translations of the banned books.

The fact that the repertoire was cleansed of any vulgar terms and preferred euphemism to the outspoken specific term (for body parts, for the sexual act, and so on) suggests an intervention of self-censorship in this piratical production as well. All participants (producers and readers) were perfectly aware of what was "right" and what was "wrong." In this subversive market, using words like "breasts," "hips," "shameful parts," "hidden parts," "member," or "erection" was sensational enough. The repertoire of situations was pornographic, and, depending on the case, so were some of the photographs or illustrations of the prototypical "sexy" girl (this being a literature for men and by men, mostly girls and women were portrayed). The language was euphemistic, thus evasive, and pseudo-literary.

The third option in literature about sex was legitimate, though just as marginal in the literary canon. It was in fact the only legitimate genre, comprised of a variety of pseudo-medical sex guides. This genre, though enjoying great popularity from the 1930s to the 1980s, has as yet not been accounted for in any historical overview of Hebrew 
translation, probably because of its minor status in literature and persistent puritan ambivalence. With the exception of August Forel's famous 1922 [1906] The Sexual Question, Freudian textbooks were the most prevalent among the translations and they served as models for their Hebrew equivalents. British or American texts, such as Havelock Ellis's 1897-1910 Studies in the Psychology of Sex or, later, Kinsey's (1948, 1953 respectively) Sexual Behavior in the Human Male/Female were either not translated (none of Ellis's seven volumes) or partially translated (Sexual Bebavior in the Human Female, 1954). Apart from the familiarity of Hebrew translators and writers with the Freudian school, the main reason for the predilection for this school was its preoccupation with sublimation. While aiming to sever all roots with the past, Zionism in fact maintained a continuum of suppression of the erotic for the sake of "higher values." Sex was channelled to the "safe" informative discourse, where it could be discussed, regulated, and surveyed.

The preoccupation with sex in the pseudo-clinical field is to be understood in Foucault's terms of the Western obsessive "verbalization of sexuality," but also within the realization that knowledge about sex meant power, and was, therefore, to be kept in the hands of the elite group of culture shapers (Foucault 1967, 26; Dworkin 1981 [1979], xxxiii). It is not surprising, consequently, that though the various textbooks differed in detail, they shared several basic common features. First, their approach to sex was ambivalent: they all waged war against prejudice, superstition and ignorance, yet underlying their modern tolerance, there still lurked a preoccupation with moral questions, with prostitution, disease, and hygiene. The 1962 translation of Dr. Fritz Kahn's 1937 volume Unser Gescblechtsleben begins with the statement, "This book was written out of two motives: experiences of suffering and sympathy for it" (Kahn 1962, 25). Not only Havelock Ellis's research but also his spirit of "enthusiasm" for sex was lacking. ${ }^{2}$

Another feature these books had in common was their style. Due to their "legitimacy," from the lexical point of view, these books were responsible for the revival/updating/invention of sexual terminology and repertoire, an enormous task, seeing that the only database was 
Biblical or Talmudic. They achieved this by reviving old terms or by borrowing/imitating/literally translating foreign (usually German) terminology, the result being that their texts sounded far removed from the Hebrew vernacular. The overall style of the textbooks was "high," as was the norm, and since they lavishly quoted classic poetic sources it was in parts "literary." This combination of dry old-fashioned German-sounding pseudo-scientific terminology embedded in highliterary, old-fashioned style characterized sexual textbooks until 1970, when the translation of Dr. David Reuben's Everything You Always Wanted to Know About Sex broke with this tradition, gaining immense popularity. Style did not categorically distinguish the textbooks from pulp fiction or the translations of banned books, and in fact they may equally have served as a source of erotic excitement. Erica Jong describes a similar experience in the puritanical America of her youth (quoted in de St. Jorre 1994, 125):

It was impossible to obtain a copy of John Cleland's Memoirs of a Woman of Pleasure outside the rare-book room of a college library or a private erotica dealer. (I tried.) Henry Miller's Tropics and D.H. Lawrence's Lady Chatterley's Lover could not be purchased at your local bookstore. The raciest sex manual available to the panting adolescent was Love Without Fear by Eustace Chesser, MD.

\section{Repertoire dwindling}

The consequences of the basically self-inflicted puritanism in marginal literature were, as is to be expected, a constant dwindling of the erotic repertoire. Hebrew everyday vernacular developed independently; the frozen literary repertoire did not offer any creative Hebrew alternatives to the foreign negative-sounding spoken slang. The vernacular, on the other hand, seldom had any impact on the literary repertoire, the latter developing until well into the 1970s with marked disdain for spoken Hebrew. When central Hebrew writers attempted in the 1970s to find a 
private, intimate tone, they had hardly any accessible modern erotic repertoire to fall back on. Faced with the choice of the old-fashioned petrified terms or the slang street vernacular, they usually compromised by avoiding explicit descriptions, in turn not a productive procedure.

The 1980s — and especially the 1990s — introduced belated novelties such as translated feminist writing and thought, gender studies, queer literature, literature written by women, folkloristic surrealism, and modernistic or postmodernistic trends. Their translation necessitated re-evaluation of the existing repertoire, which, in due course, supplied material for the renewal of original literature. Alternative undercurrents of the Zionist narrative could now regain vigour and find a legitimate place in the centre, sometimes replacing part of the canonical repertoire. Feministic trends, if not directly responsible for the revival of literature written by Israeli women, certainly helped young women writers develop a modern erotic voice of their own, and the last two decades have witnessed both a flourishing of women writing and a consequent refreshing change of norms. ${ }^{3}$ Yet as of January 2004, when the new publishing house "Katom" heralded the appearance of a Hebrew pornographic series and was acclaimed with reactions such as "High time! Pornography in Hebrew!" Israeli erotica is still neither self-evident nor "normalized."

This petrifaction of erotic repertoire stood in direct opposition to the energetic, even hectic process of Hebrew revival that took place in the last century. None of the personalities (poets, writers, teachers, lexicographers) involved in modernizing Hebrew would have anything to do with the "obscene". A lexicon for Gynecology was finally issued in the 1990s: a scientific essay about the possible etymology of the slang lexeme 'zayin' (prick) was rejected by the Language Academy organ, only to be reluctantly accepted to its humoristic Purim issue. The erotic repertory was left in the hands of amateurs. ${ }^{4}$

\section{Conclusion}

The seemingly "minor" case of Hebrew translated erotic literature, so far not subject to any systematic research, offers an alternative viewpoint on the development of literature and literary translation in Israel, 
mobilized for decades to enhance the representation of the New Sabra. This type of analytical retrospective throws more light on the presentation of a history of Hebrew translation, and eventually the creation of Hebrew culture, in Israel. It is crucial to the understanding of censorship as a vehicle for shaping the self and delimiting the other. In this retrospective, the clash between enthusiastic revival on the one hand and manipulative suppression on the other must produce selfdefeating tensions.

NITSA BEN-ARI Tel Aviv University (Israel)

\section{Notes}

1. The booklets were nicknamed the "Stalags" after the unprecedented success of the first title, Stalag 13, itself named after Billy Wilder's 1953 movie Stalag 17. Stalag 13 came out in the early sixties and sold 25,000 copies, making it a bestseller in terms of the period as well as by today's standards.

2. Paul Robinson's epithet for Ellis is a "sexual enthusiast" (Robinson 1989 [1976], 2-3). He quotes Ellis's view of sex as "the chief and central function of life .. . ever wonderful, ever lovely" (Robinson 1989 [1976], 27; Ellis 1890, The New Spirit, 129).

3. Israeli women's approach to feminism is not clear-cut. The liberated woman myth makes feminism appear irrelevant. Many of the basic feminist texts have either not been translated or were translated with considerable delay. For example, only the first part of Simone de Beauvoir's (1949) The Second Sex was translated into Hebrew, in 2001(!).

4. The Chinese-American writer Anchee Min describes the same phenomenon in her novels about Mao's Cultural Revolution. Japanese translators have reported similar cases, such as the case of the Japanese new translation of the Boston Women's famous Our Bodies Ourselves: A Book by and for Women. When, in 1988 a group of twenty-three translators and twenty-five editors set out to prepare a full translation of the book, they found that the terms used in the 1974 Japanese translation had been negatively marked and would have to be replaced. 


\section{References \\ Primary Sources}

Apollinaire, Guillaume. (1998) [1907]. Zichronotav shel Don Juan Tzair [Les Exploits d'un jeune Don Juan], trans. Avi Deutsch. Hod Ha-Sharon: Astrologue.

Cleland, John. (1963-1964) [1774]. Zichronoteha shel Eshet Taanugot: Fanny Hill [Memoirs of a Woman of Pleasure: Fanny Hill], trans. G. Kasim [pseudonym for the poet Maxim Gilan]. N.p.: Great Art and A.I.

- (1986). Fanny Hill, trans. M. Aharon [possibly a pseudonym]. Tel Aviv: Deme.

Cleyland [sic], John. (1999). Fanny Hill: Yomana shel Naara Taavtanit [Fanny Hill: Diary of a Passionate Girl], trans. Mira Harel. Hod Hasharon: Astrolog. Clay [sic], John. (1964). Chadar Ha-sbena shel Fanny Hill [Fanny Hill's Bedroom], trans. Avner Carmon [one of the pseudonyms of Uriel Miron, author of a great number of pulp texts]. Tel Aviv: Olympia.

Ellis, Havelock. (1890). The New Spirit. London and Felling-on-Tyne. New York: Walter Scott Publishing Co.

Forel, August. (1926). The Sexual Question: A Scientific, Psychological, Hygenic and Sociological Study. English adaptation from the second German edition, revised and enlarged by C. F. Marshall. Brooklyn: New York, Physicians and Surgeons Book Company. Hebrew translation: Ha-sheela Ha-minit (1931). 3 vols. Tel Aviv: Mitzpeh.

Kahn, Fritz, Dr. (1962). Chayenu Ha-miniyim: Madricb Ve-yoetz Le-chol Isb Ve-isha [Our Sex Life: A Guide and Advisor for Every Man and Woman], trans. Baruch Karu. Jerusalem: Achiasaf; Tel Aviv: Bronfmann.

Koestler A., MD, and A. Willie, MD. (1946). Encyclopedia Le-madaei Ha-min [Encyclopedia for Sexual Sciences], ed. Norman Hare, trans. Yaacov BenGera. 2 Vols. Jerusalem: Shahar.

Lawrence, D. H. (1938) [1928]. Meabava shel Lady Chatterley [Lady Chatterley's Lover], trans.Baruch Krupnik. Tel Aviv: Mitzpeh.

. (ca. 1964). Meabava sbel Lady Chatterley, trans. Baruch Krupnik. Tel Aviv: Mizrahi.

(1973). Meabava shel Lady Chatterley, trans. Aharon Amir. Tel Aviv: Am Oved.

(1987). Meabava shel Lady Chatterley, trans. Aharon Amir. Tel Aviv: Am Oved. [Hardcover].

Miller, Henry. (1962) [1934]. Chugo shel Sartan [Tropic of Cancer], trans. Shula Efroni. N.p.: Deshe Pocket Books.

(1964). Chugo sbel Sartan [same translation], trans. Edna Kornfeld, Shula Efroni. Tel Aviv: Sadan. 
(1985). Chug Ha-sartan, trans. Yoseph Grodjinski. Tel Aviv: Modan.

Nabokov, Vladimir. (1959). Lolita, trans. Yoseph Varhaftig. Tel Aviv: Maariv Pocket Books.

. (1986). Lolita, trans. and intr. Dvora Steinhart. Tel Aviv: Ha-kibbutz Ha-meuchad, Jerusalem: Keter.

Omer, Dan. (1966). Ba-derex [On the Road]. Jerusalem: Golgotha.

Réage, Pauline [Dominique Aury]. (1999) [1954]. Sipura jel O [Histoire d'O], trans. Moshe Ron. Israel: Ha-Kibbuts Ha-meuchad.

Reuben, David MD. (1970) [1969]. Kol Ma She-tamid Ratzita Ladaat al Ha-min *Aval Lo Heazta Lisheol. [Everything You Always Wanted to Know About Sex *But Never Dared to Ask], trans. Eliezer Karmi. Tel Aviv: Bustan.

Zohar, Zvi, and Shmuel Golan. (1941). The Sexual Education. Tel Aviv: Sifriat Poalim.

\section{Secondary sources}

Allison, Ann. (2000) [1996]. Permitted and Probibited Desires: Mothers, Comics and Censorship in Japan. Berkley, Los Angeles, London: University of California Press. Ben-Ari, Nitsa. (1997). Romance with the Past: The $19^{\text {th }}$ Century German-Jewish Historical Novel and the Emergence of a National Literature. Tel Aviv and Jerusalem: Dvir and Leo Baeck. [Hebrew, German translation].

. (2000). "Ideological Manipulation of Translated Texts," Translation

Quarterly, 16 and 17, 40-52.

. (2002). "The Double Conversion of Ben-Hur: A Case of Manipulative

Translation." Target, 14:2, 263-302.

. (2006). Suppression of the Erotic in Modern Hebrew Literature. Ottawa:

University of Ottawa Press.

Biale, David. (1994) [1992]. Eros and the Jews. Tel Aviv: Am Oved. [Hebrew].

Bourdieu, Pierre. (1980). Questions de sociologie. Paris: Minuit.

Buckley, Sandra. (1997). Broken Silence: Voices of Japanese Feminism. Berkley, Los Angeles, London: University of California Press.

Cohen, Haim. (1973). On Forbidden Books. Tel Aviv: Am Oved. [Hebrew].

Dworkin, Andrea. (1981) [1979]. Pornography: Men Possessing Women. London: Women's Press.

Eshed, Eli. (2000). From Tarzan to Zbeng: The Story of Israeli Pop Fiction. Tel Aviv: Babel. [Hebrew].

Even-Zohar, Itamar. (1990). Polysystem Studies. Poetics Today, 11, 1. . (2002). "Culture Planning and Cultural Resistance in the Making and Maintaining of Entities." In Sun Yat-sen Journal of Humanities, 1445-52. Also in: http//www.tau.ac.il/ itamarez/papers/plan-res.html. 
Feiner, Shmuel. (1998). "The Modern Jewish Woman: A Test-Case in the Relationship Between Haskalah and Modernity." In Sexuality and the Family in History, eds. Israel Bartal and Isaiah Gafni. Jerusalem: Zalman Shazar Centre for Jewish History, 253-304. [Hebrew].

Foucault, Michel (1976): Histoire de la sexualité. Tome I. La Volonté de savoir. Paris: Gallimard.

Fraxi, Pisanus. (1962) [1885]. Catena Librorum Tacendorum (Bibliography of Probibited Books). Vol. 3. New York: Jack Brussel.

Greenawalt, Kent. (1995). Fighting Words: Individuals, Communities and Liberties of Speech. Princeton University Press.

Greenblatt, Stephan. (1992). Marvellous Possessions. The Wonder of the New World. Oxford: Clarendon Press.

Lawrence, D.H. (1961) [1929]. A Propos of Lady Chatterley's Lover and Other Essays. England and Australia: Penguin.

Lefevere, André. (1995). "Translation: Its Genealogy in the West." In Translation, History and Culture, eds. Susan Bassnett and André Lefevere. London: Cassel, $14-28$.

Loth, David. (1961). The Erotic in Literature. London: Secker and Warburg.

Merkle, Denise. (2002). Presentation to Censorship and Translation in the Western World. TTR, XV:2, 9-18.

Miron, Dan. (1993). "Reflection on a Prose Era." In 30 Years, 30 Stories: An Anthology of Hebrew Stories from the 60's to the 9o's, ed. Zisi Stavi. Tel Aviv: Yediot Aharonot, 397-427. [Hebrew].

Mosse, George L. (1985). Nationalism and Sexuality: Middle Class Morality and Sexual Norms in Modern Europe. Madison: University of Wisconsin.

Peakman, Julie. (2003). Mighty Lewd Books: The Development of Pornography in Eighteenth-Century England. England: Palgrave Macmillan.

Rembar, Charles. (1968). The End of Obscenity: The Trials of Lady Chatterley, Tropic of Cancer and Fanny Hill. New York: Random House.

Robinson, Paul. (1989) [1976]. The Modernization of Sex: Havelock Ellis, Alfred Kinsey, William Masters and Virginia Jobnson. Ithaca, New York: Cornell University Press.

Rubinstein, Amnon. (1975). Moral Enforcement in a Liberal Society. Jerusalem: Schocken. [Hebrew].

Sela-Sheffy, Rakefet. (1997). "Models and Habituses: Problems in the Idea of Cultural Repertoires." Canadian Review of Comparative Literature, XXIV:1, 35-47.

Shavit, Zohar. (1998). "The Status of Translated Literature in the Creation of Hebrew Literature in Pre-State Israel." META, 43:1, 46-53.

Spiro, Melford E. (1965). Children of the Kibbutz. New York: Schocken.

St. Jorre, John de. (1994). The Good Ship Venus: The Erotic Voyage of the Olympia Press. London: Hutchinson. 
Suleiman, Susan R. (1986). "Pornography, Transgression and the Avant-garde: Bataille's Story of the Eye." In The Poetics of Gender, ed. Nancy K. Miller. New York: Columbia University Press.

Toury, Gideon. (1980). "Translation." Hebrew Encyclopaedia, 1063-1065. (1995). Descriptive Translation Studies and Beyond. Amsterdam-Philadelphia: John Benjamins.

Tymoczko, Maria, and Edwin Genzler. (2002). Introduction to: Translation and Power, pp. xi-xxviii. Amherst and Boston: University of Massachusetts Press. Wakabayashi, Judy. (2000). "Subversion, Sex and the State: The Censorship of Translation in Modern Japan." Translation Quarterly, 16 and 17, 53-78. 
This page intentionally left blank 


\section{Ideologies in the History of Translation A Case Study of Canadian Political Speeches ${ }^{1}$}

\section{Introduction}

In Canadian history, many sociopolitical conflicts have arisen from the 1 coexistence of two different peoples in a single land. For instance, one can think of Canada's Conscription Crisis in 1942, its October Crisis in 1970, or its failure to conclude the Meech Lake Accord in $1990 .^{2}$ Rival nationalism is often called upon to explain these conflict situations between French and English Canadians. According to sociologists Bourque and Duchastel (1996, 315), until 1960 two nationalisms clashed with one another: that of the French community, based on the FrenchCanadian "race" and the Roman Catholic faith, and that of the English community, based on the Anglo-Saxon "race" and the Protestant faith. With the changeover to a welfare state in the 1960s, these nationalisms were replaced by a Quebec nationalism and a Canada-wide nationalism. Despite the numerous disputes between francophones and anglophones in Canada, Canadian prime ministers have always laid emphasis on the benefits of having people from French and English backgrounds 
living side by side in one country. William Mackenzie King, for example, stated in the Parliament of Canada in 1942:

1. In the whole history of the world, no two peoples have ever lived so long in such close association with so little friction as those of French and British descent in Canada. In a century of political union we have built a nation which stretches across half a continent. We have conquered the wilderness. We have achieved great material progress. We all have become deeply attached to one common homeland.

Il n'est pas dans l'histoire du monde deux autres peuples qui aient vécu aussi longtemps en étroite association et avec moins de conflits que les peuples d'origine française et anglaise au Canada. Dans un siècle d'union politique nous avons édifié une nation qui couvre la moitié d'un continent. Nous avons conquis la solitude. Nous avons réalisé un grand progrès matériel. Nous nous sommes tous profondément attachés à une patrie commune.

This excerpt (1) which celebrates the association of francophones and anglophones in Canada, was paradoxically taken from a political speech delivered in a national crisis situation in 1942, during which the unity of the country was challenged by a clash between these two speech communities. Moreover, in comparing the English quotation with its French translation, one notices a translation shift ("wilderness" translated by "solitude") which creates two different images of the same event. These contradictions merit closer examination, and we will here investigate the strategies put forward by the federal government in Canada to protect its institutional discourse.

In this paper, the following question will be considered: in Canada, what role has the translation of political speeches been playing in the construction of a discourse on Canadian unity? The translated speeches investigated were delivered in national crisis situations in the twentieth century. With such a history-related corpus, where the translated 
speeches were crafted to deal with acute tensions between the francophones and the anglophones of this country, it will be possible to contrast the slightly different messages sent to these speech communities when serious and controversial issues have taken place. Moreover, it is hoped that ideological translation shifts will help to reveal the value system of the Canadian society at given points in contemporary history.

\section{Corpus and theoretical framework}

The term "political speech" is here defined as a formal talk delivered with a political purpose to a specific audience. The umbrella term "political discourse" includes not only political speeches, but also all forms of political texts. The corpus studied here comprises seven speeches, delivered in both French and English in national crisis situations. These speeches fall under the category of "addresses to the nation," which have been used throughout Canadian history when the unity of the country was at stake, or when the prime minister wanted to speak to all his fellow Canadians at the same time. Addresses to the nation are usually pre-recorded in French and in English, and then simultaneously broadcast on radio or on television. The speeches in the corpus include:

- one by William Mackenzie King during the Conscription Crisis in 1942;

- three by Pierre Elliott Trudeau at the time of the October Crisis in Quebec in 1970, when the Parti Québécois came to power in 1976, and during the first referendum on Quebec independence in 1980;

- Brian Mulroney's speech in 1990 when the Meech Lake Accord was defeated

- and finally, two speeches delivered by Jean Chrétien, before and after the second Quebec referendum in 1995.

As a basis for argumentation, let us state that the translation shifts in this corpus will presumably be related to the Canadian federal government's institutional ideology. This hypothesis is based on existing studies of the translation of political discourse in Canada. For instance, both 
Charron's research (1997) on the translations of Lord Durham's Report and our own research on the translation of political speeches in Quebec and in Canada (Gagnon 2002) seem to indicate that translations of Canadian political discourse reflect the ideology of the translating institution. Hence, in Canada, the translation of political discourse plays a major role in the reproduction of ideologies and contributes to certain discourses as promoted by different social groups.

As stated by Chilton (1997, 181): "What discourse analysis can make clear is that 'nations' and 'ethnic identity' are not natural or universal phenomena that have simply 'resurfaced' after being suppressed. They have to be constructed and promoted through discourse." The notion of discourse is quite important here. Indeed, a discourse is a way of speaking or writing which represents the attitude of a social group or its expression with respect to certain areas of social life (Hatim and Mason 1997). Ideology and discourse are closely related concepts, ideology meaning a worldview based on the values and interests of a person, a group of people or an institution (Hatim and Mason 1997). Van Dijk's views on ideology (1998) differ slightly: for this scholar, ideologies are acquired through a socialization process, meaning that an individual's ideology is only the expression of a group's ideology at the personal level. Ideologies are not exclusively found in circumstances of hegemony, but they certainly are easier to pinpoint in such contexts. For instance, in a crisis situation, power struggles are at peak level, and divergent ideologies are strongly reflected in the confrontation.

The present research is based on a theoretical model of Critical Discourse Analysis (CDA), studying ideologies and institutional discourses. As remarked by Fairclough $(1989,40)$, power struggles play a prime role in the process of discourse reproduction or transformation. He also observes that when power struggles are "stable," the reproduction of ideologies is carried out in a conservative way. However, when the situation becomes unstable, such as the one in this corpus, the discourse must be transformed if it is to remain in a dominant position. 
Although it has not been part of the traditional toolkit in historiography, discourse analysis is nonetheless an important asset for the historian, as argued by Struever $(1985,250)$ :

Investment in discourse analysis technique . . . is an economical expenditure for the historian. . . . It functions as a tool of inquiry in the traditional task of interpretation of source, the exploitation of the archive of pertinent discourses that the historian uses to reconstruct the past. It is a formalist project that promises direct access to significant social process; the formal description of the functioning of a discursive practice is at once the description of the structures and processes of social action.

Critical or not, discourse analysis provides an interesting framework with which to look at historical texts, and it helps to understand the social, economic, linguistic, and political issues in such texts. Moreover, Critical Discourse Analysis offers another beneficial feature: its transdisciplinarity. Indeed, CDA attempts to bridge the gap between social sciences and textual analysis, as explained by Fairclough (2003, 2-3):

My own approach to discourse analysis has been to try to transcend the division between work inspired by social theory which tends not to analyse texts, and work which focuses upon the language of texts but tends not to engage with social theoretical issues.

One cannot help but relate this statement to translation studies' own dichotomy between postmodern or cultural studies approaches on the one hand, and descriptive or linguistic approaches on the other (see Chesterman and Arrojo 2000). The translation scholar Calzada Pérez (2001) suggested that the solution to this "clash" could lie in translation studies research based on CDA. The present work should be considered as another contribution to such a theoretical/methodological pathway.

This case study will be structured as follows. First, the concept of 
translation shifts will be discussed with reference to Chesterman's taxonomy (1997). Second, translation shifts will be analyzed using CDA as a theoretical framework. Third, and as a conclusion, this paper will briefly go over some of the causes and strategies related to the shifts studied.

\section{Description of translation shifts}

Among the translation scholars who have looked at the translation of political discourse, (including Baumgarten 2001, Calzada Pérez 2001, Gagnon 2003, Hatim and Mason 1991, and Schäffner 2003), many have chosen a linguistic typology based on text linguistics, on critical discourse analysis, or on functional grammar. Examples of textual markers studied in translated political discourses are transitivity (Calzada Pérez 2001), cohesion (Hatim and Mason 1997, 143ff), metaphors (Al-Harrassi 2001) or lexical choices (Schäffner 2003). The results obtained using these typologies are of the utmost importance for the study of translated political discourse, since they represent the first attempts at describing translation shifts in political discourses. However, two problems arise with these classifications. First, they do not explicitly refer to certain issues specific to translated texts, such as omission/addition, explicitation/implicitation, or the translator's visibility. In fact, until now, most translation scholars working on translated political discourse have adapted linguistic typologies to their work in translation studies. These typologies were not primarily developed to account for translational phenomena. Second, only targeting linguistic markers traditionally used to find ideologies in texts might result in overinterpreting the ideological relevance of these markers.

For these reasons, Chesterman's taxonomy (1997, 87-112) will be used here as a test case study to describe shifts in translated political speeches. ${ }^{3}$ Chesterman entitles his classification "translation strategies," but it will here be referred to as "translation shifts" in order to avoid confusion. Indeed, there is a general lack of consensus in translation studies on the concept of translation strategy (Molina and Hurtado 
Albir 2002). It is argued here that translation strategies go beyond the description level of analysis, since they help to explain the translator's behaviour. We do not agree with Chesterman's statement that strategies are text-based. Rather, strategies are procedures used by translators to solve problems (Molina and Hurtado Albir 2002), and they are inferred from texts. In contrast, a "shift" is text-based, and it should be taken as a difference in meaning or in structure between a translation and its original. However, Schäffner's research (1997) has shown that with texts produced in multilingual settings, it is quite difficult to differentiate source and target texts, and multilingual institutions often present their translated political discourses as "originals." The speeches in this corpus are also presented as bilingual originals by the Government of Canada, and the concept of "shift" will here refer to a difference in meaning or structure between two language versions of a text.

Chesterman's heuristic model includes three levels of analysis: syntactic, semantic, and pragmatic. Shifts at the syntactic level modify the textual form (such as clause structure change); shifts at the semantic level modify textual meaning (as does synonymy); and those at the pragmatic level modify the textual message itself (for example, visibility change). Let us emphasize that these three groups overlap, and that shifts at the pragmatic level often involve shift(s) at the syntactic and/or semantic level. Also, different shifts can occur at the same time. As Chesterman himself states, his model is a useful conceptual tool to discuss translations and translation choices. For the study of translated political speeches in particular, Chesterman's classification is general enough to target some of the traditional linguistic markers used to unveil ideology in translated political discourse, yet it is not restricted to these features.

Although Chesterman's model is quite comprehensive and well structured, there seems to be a lack of coherence between the first two levels of analysis and the third one. Indeed, at the syntactic and semantic levels, the shifts mainly fulfill a description function; that is, they label the changes occurring between source text and target text. At the pragmatic level, the functions of the shifts are rather mixed, some describing 
the linguistic features of translations, such as information change or explicitness change, while others present a deeper level of analysis, such as cultural filtering, interpersonal change or illocution change. In fact, the latter are examples of strategies as defined above. To deal with this inconsistency, we have slightly modified Chesterman's work: interpersonal change and illocution change have been removed from the classification, and the concept of cultural filtering has been replaced with the concept of adaptation, ${ }^{4}$ inspired by the book Translation Terminology (Delisle et al. 1999, 114). Hence, adaptation means a shift "where the translator replaces a sociocultural reality from the source language with a reality specific to the culture of the target language in order to accommodate the expectations of the target audience." Unlike Chesterman's concept of "cultural filtering," "adaptation" does not necessarily entail the ideological issues related to Venuti's work (1995). The reader will appreciate that the slight changes to Chesterman's work introduce a classification focusing almost exclusively on description features. The modified taxonomy is briefly detailed in Appendix 1.

In order to describe the translated speeches in linguistic terms, the French and English versions of the speeches were first analyzed, and shifts were identified at the textual surface. A corpus-based study was carried out as well, using the monolingual concordancer WordSmith Tools 4.0 and the bilingual concordancer Multiconcord 1.53. These software systems were useful for locating patterns among the identified shifts. Finally, the shifts were labelled using Chesterman's modified taxonomy.

For this case study we retained only shifts related to the lemma "Canada" (such as Canada, Canadian[s], Canadien[s], Canadienne[s]), and the words surrounding it. According to Duchastel and Armony (1993), the lemma "Canada" is a "macropolitical entity." The macropolitical entity designates great societal ensembles (the concepts of nation, people, government, country, and so on) and it is one of the key social components in the production of political discourse, since political discourses portray the world in a way that reflects "us vs. them" frameworks. Another argument in favour of focusing on "Canada" lies in 
Bourque and Duchastel's study of Canadian political discourse (1996). Indeed, these two scholars have established a clear link between the frequency of the lemma "Canada" and the production of a national discourse on identity. Other studies are related to the translation of the word "Canada" (Delisle 1993, 340-341; Mossop forthcoming), but for reasons of space they will not be dealt with in this paper.

\section{Discussion of results}

This analysis of translation shifts aims at understanding the evolution of Canada's institutional discourse in Québécois and Canadian society. It is worth stating here that a rigorous study should include a great variety of shifts in order to account for ideological dimensions in translations. Consequently, this study looks for patterns in translation shifts rather than examining isolated cases. However, following CDA methodology, this research is more qualitative than quantitative in nature. It is of course impossible to assume a one-to-one relationship between translation shifts and ideology. That is why the relations established between shifts and ideology are always potential ones.

The identified translation shifts have been divided into two main categories. The first category includes syntactic and pragmatic shifts, and is related to the lemma "Canada." From these shifts, it was found that the relationship between speaker and hearers, that is, the prime minister and his citizens, changes from one language version to another. In the second category, the shifts belong to the semantic and pragmatic group, and are associated with the surroundings of the lemma "Canada." Such analysis tends to prove that the ideological presuppositions related to the Canadian identity differ from one language version to another. The next two sections will deal in turn with these two categories of shifts.

The prime minister and his fellow citizens

Looking at the different translations of "Canada," it seems that the observed shifts had an effect on the prime minister's position towards 
his francophone or anglophone audience. In some cases, personal pronouns or indefinite pronouns were used in French, whereas the words "Canada" or "Canadian(s)" were used in English. These syntactic shifts contributed to changes in the cohesion of the discourse. Cohesion is seen as a feature which affects, among other things, intratextual reference, substitution or pronominalization (Chesterman 1997, 98). Examples from two speeches delivered in 1970 and 1976 by Pierre Elliott Trudeau are provided here [our emphasis]:

2. Syntactic shift, cohesion change and transposition

Notre présomption était peut-être naïve, mais elle s'expliquait aisément, parce que la démocratie est solidement enracinée CHEZ NOUS, et parce que NOUS avons toujours attaché le plus grand prix à la liberté individuelle.

Our assumption may have been naive, but it was understandable; understandable because democracy flourishes IN CANADA, understandable because individual liberty is cherished IN CANADA.

3. Syntactic shift, cohesion change and transposition

Le scrutin du 15 novembre au Québec a fait naître CHEZ LES UNS beaucoup d'espoir et CHEZ LES AUTRES une grande inquiétude, mais tous se posent beaucoup de questions. . . .

To some CANADIANS last week's election in Quebec has given rise to many hopes. To many other CANADIANS it has been a cause of great concern, but to all it has posed many questions. . . .

As stated by Duchastel and Armony (1993), in any political discourse the speaker adopts a certain position using certain linguistic operations. Such positioning defines his or her political role. For instance, in passages (2) and (3) in English, the Prime Minister placed himself in the Canadian context. In French, however, the location was implicit, even ambiguous. Indeed, the pronominal form was used to talk to the French Quebec audience, and the statement could have been received from either a Canadian or Québécois perspective. This double meaning was 
only possible because the Liberal Prime Minister Pierre Elliott Trudeau was a Québécois. One possible explanation for this shift is that ever since 1960, most people in French Quebec have identified themselves as "Québécois" rather than (or along with) "French Canadians." Moreover, nationalist issues were quite a sensitive point both in 1970 and 1976; in 1970 nationalist terrorism struck the province of Quebec, and 1976 marked the first election of a nationalist party in the Quebec government. Trudeau's speeches were delivered in reaction to these events. Pronouns, however, have not solely been used to create ambiguity in the different French versions. They sometimes did quite the opposite, and the prime minister then presented himself as a Canadian speaking to fellow Canadians. Interestingly, these shifts were more common in speeches from the 1990s. During this period, Brian Mulroney's Conservative government tried twice to modify Canada's constitution in order to meet Quebec's traditional demands, and these initiatives partly contributed to a slowing down of the separatist movement. However, when Mulroney's first attempt (the Meech Lake Accord) failed, polls indicated that nearly 60\% of the Quebec population wanted separation from Canada. This eventually led to the second referendum in 1995. The following examples were taken from speeches delivered after the defeat of the Meech Lake Accord in 1990 and after the Quebec referendum five years later (our emphasis).

4. Syntactic shift, cohesion change and scheme change

NOUS, CANADIENS, avons toujours surmonté dans le passé les obstacles à notre unité, et nous le ferons encore.

CANADIANS have always overcome challenges to our unity and we shall do so again.

5. Pragmatic shift, information change

À tous les Canadiens, je dis qu'une majorité de Québécois ont choisi le Canada en partie grâce à l'extraordinaire témoignage d'amitié et de bonne volonté que vous avez manifesté la semaine dernière. DES CANADIENS COMME VOUS ET MOI, du Québec et 
de tout le Canada, se sont levés et nous ont montré ce que représente ce pays.

To all Canadians, I say that a majority of Quebecers have chosen Canada in part because of the incredible outpouring of good feelings and goodwill demonstrated over the last week. ORDINARY CANADIANS, inside Quebec and throughout Canada, stood up and proved what this country is all about.

In French, Prime Ministers Brian Mulroney and Jean Chrétien clearly stated their Canadian identity and tried to identify with their FrenchCanadian audience. In the English speeches, however, the word "Canada" is more iconic than the inclusive "nous." In fact, in the entire corpus, the French "nous" is more frequent (149 times) than the sum of "we" and "us" (133 times) in English. As the psycholinguist Íñigo-Mora (2004) argued, there is a strong connection between personal identity (in terms of inclusion or exclusion from a group) and pronominal choice in political discourse. Looking at examples (2) to (5), it seems that the repositioning of sociopolitical relationships represented an important translation strategy adopted by the Canadian federal government. Through changes in pronominal features, this positioning was either used to avoid sensitive issues (examples 2 and 3 ) or to create solidarity (examples 4 and 5). Furthermore, results from examples (2) to (5) are useful for identifying three influential factors in the translation of political speeches: the audience, the prime minister's "nationality," and the historical period during which the speech was delivered.

William Mackenzie King's case seems to corroborate these early findings. Shifts modifying the relation between speaker and hearers were almost non-existent in his speech from 1942. This Liberal leader did promote Canadian unity, but more from an Anglo-Saxon perspective than a Canada-wide one. Further, King was not Québécois and did not speak French at all. It would have been quite difficult for him to convince the French Canadians ${ }^{5}$ that he was part of their group. This does not mean, however, that under his leadership the translated speeches 
were free of any potential ideological shifts. Let us consider the following example [our emphasis]:

\section{Pragmatic shift, adaptation}

Looking across the Pacific, they ask . . . why should the Japanese attempt to come and install themselves ... in BRITISH COLUMBIA? Et tournant les yeux du côté du Pacifique, ils se demandent pourquoi les Japonais . . . voudraient tenter de venir s'installer . . . dans la COLOMBIE CANADIENNE.

In Canada in the 1940s, the proper noun "British Columbia" was sometimes translated in French by "Colombie canadienne" in protest against British imperialism. In fact, when King's speech was printed in full in the French-Canadian press, La Presse kept "Colombie britannique," whereas the nationalist newspaper Le Devoir, from which the above excerpt is taken, chose "Colombie canadienne." It would seem that Canadian newspapers sometimes changed information in political speeches according to their editorial line. That is to say that Canadian media also play an important role in the translation and diffusion of national political speeches. Hence, a fourth factor is identified for the translation of political speeches: the place of publication.

\section{About Canada and Canadians}

In this section, the translation shifts in the surroundings of the lemma "Canada" are investigated. In particular, it is observed that presuppositions towards the Canadian identity differed between French and English versions of the prime ministers' speeches. It is also argued that these translation shifts contributed to a "face-work" process (Goffman 1967), where the hearer's self-image (face) was maintained in all versions of the speeches.

Let us start with the case of Pierre Elliott Trudeau's speech after the first Quebec referendum in 1980. The French version related to an identity quest, whereas the English version showed the prime minister's pride in and fidelity to Canada. 


\section{Semantic shift, synonymy}

Et c'est sur cette volonté de changement qu'il faut tabler pour renouveler la fédération canadienne et REDONNER à tous les Québécois comme à tous les citoyens de ce pays, LE GOÛT D'ÊTRE ET DE SE PROCLAMER CANADIENS.

It is upon this desire for change that we must build a renewed Canadian federation, which will GIVE to the people of Quebec and the whole country MORE REASONS TO PROCLAIM PROUDLY THAT WE ARE CANADIANS.

8. Semantic shift, synonymy

Et les Québécois ont choisi majoritairement de rejeter la souveraineté-association et d'OPTER POUR LA VOIE DE LA FIDÉLITÉ AU CANADA.

A majority of them have decided to reject sovereignty-association, and to EXPRESS THEIR LOYALTY TO CANADA.

These examples seem to indicate that the francophones did not feel themselves to be Canadians as strongly as did the anglophones. In fact, a statement in French such as "donner aux Québécois une raison de plus de se proclamer fièrement Canadiens" could not have sounded right to a French Québécois ear in 1980. It even could have been considered as a face-threatening act (FTA), meaning that the statement would have challenged the hearer's self-image (Brown and Levinson 1978). In the first Quebec referendum, around 40\% of the Quebec population voted for the independence option, hence proving that many of them were discontented with Canada. A strong and direct challenge to the Quebec nationalist discourse might have denied Québécois' need for distinctiveness and rejected their "basic claim to territories, personal preserves, right to non-distraction - i.e., . . freedom from imposition," or, in other words, threatened their negative face (Brown and Levinson $1978,66)$. One can assume that the context around the 1980 referendum was so emotionally entangled that a single FTA could have triggered serious consequences. 
In examples (7) and (8), Pierre Elliott Trudeau implicitly or explicitly referred to a "desire for change" in his speech. The third example in this section, by Brian Mulroney, also deals with the idea of "change," in terms of promise for change.

\section{Semantic shift, synonymy}

Nous allons établir des programmes destinés à les rapprocher et à jeter des ponts entre les solitudes dans lesquelles tant de nos concitoyens anglophones et francophones DEMEURENT CONFINÉS.

We will initiate programs to bring Canadians together and bridge the solitudes in which so many English and French-speaking Canadians STILL LIVE.

In example (9), it is clear that in French, the "solitude" problem was related to isolation, whereas in English, it was a problem the citizens had to live with. The connotation was more negative in French. In the corpus, there are no counter-examples where the surroundings of the lemma "Canada" are more negative in English than in French. It could be argued that a negative statement about Canada in English would have diminished the Canadian nationalist discourse, and as such, threatened the (English-) Canadian people's positive face: their "positive consistent self-image or 'personality' (crucially including the desire that this self-image be appreciated and approved of)" (Brown and Levinson 1978, 66).

Using speech act terminology, the speeches in the first three examples could be defined as "commissive" speeches, where the prime minister had to explain what he and his government intended to do in order to resolve a national crisis. In the following and last example, the speech is "directive," in that the prime minister was trying to minimize a crisis by urging the Quebec population to vote "NO" in the 1995 referendum on independence. Although the stakes were somewhat different, the following shift nevertheless reflects differences in presuppositions. 


\section{Pragmatic shift, adaptation}

Pourquoi SOMMES-NOUS SI BIEN au Canada?

Why DOES Canada WORK?

The Liberal Prime Minister, Jean Chrétien, described Canada in French as a homely and pleasant country, whereas in English, he described it as a coherent ensemble. Knowing that the Québécois did not feel themselves to be Canadians as much as English-Canadians did, it makes sense that Jean Chrétien chose to focus, in his French version of the speech, on the "comfort" features of the country. Furthermore, the fact that a second referendum was taking place in Quebec fifteen years after the first one implied that for the Québécois, Canada still did not work. To ask "Pourquoi le Canada fonctionne-t-il si bien?" would have imposed a discourse on the Québécois that did not meet their belief. And the impact could very well have been reflected in the outcome of the referendum. After the first referendum, it was said in the French press that the controversy surrounding a speech by the Quebec minister Lise Payette had a strong impact on the referendum vote results (Godin 2001). In 1995, a "slip of the tongue" in Jean Chrétien's case could have been very costly, and he was fully aware of it.

All in all, face-work can be seen as another translation strategy put forward by the Canadian federal government. As argued by Paul Chilton and Christina Schäffner $(2002,14)$, politicians' potential FTAs are "strategically formulated to lessen the affront," and "in political situations, [an] FTA is likely to have variable value for different groups of hearers; so the linguistic formulations are chosen carefully." Chilton and Schäffner's statement referred to the speaker's choice, but it certainly can be applied to the translator's choice, especially in a case where source and target texts cannot be differentiated. Examples (7) to (10) confirm this assumption.

Interestingly, the translation strategies identified in this paper revolved around identity representation. In addition, it appears that some cases of sociopolitical repositioning (such as in examples 2 and 3) involved face-work, suggesting that there are intricate relation- 
ships between the translation strategies used to build institutional discourses.

\section{Conclusion}

To sum up, potential ideological shifts have here been identified from a corpus of Canadian translated political speeches in crisis situations. It would appear, then, that these shifts have been caused by a power struggle between the French-Canadian or Québécois nationalist discourse on the one hand and the Anglo-Saxon or Canada-wide nationalist discourse on the other. A careful analysis of these ideological shifts has singled out two translation strategies adopted by the Canadian government in its effort to disseminate a discourse on Canada's unity. These strategies are face-work process and sociopolitical repositioning. Four factors have also been identified as playing a key role in the translation of political speeches in Canada: the historical context of the speech, the place of publication, the targeted audience, and the "nationality" of the prime minister. Further research is needed to confirm and elaborate on these results, using a larger corpus and different kinds of political speeches. Nevertheless, this study seems to prove that there are (potential) ideological shifts in Canadian translated political speeches and that these shifts are closely related to different identity redefinitions as they have occurred in the course of Canadian history.

In fact, the question of identity redefinition can also be extended to other areas in translation history. Still in the Quebec/Canada context, one can draw an interesting parallel between the translation of political speeches in Canada and drama translation in Quebec. For instance, Annie Brisset's corpus (1990) on drama translation shows that in Quebec between 1968 and 1988, the social discourse focused on Quebec political and national identity. Around the same time, Pierre Elliott Trudeau delivered speeches in French where he introduced a somewhat confusing setting, and his position as a member of the Quebec community potentially preceded his role as Canadian prime minister. Since the 1990s, English-language plays translated in Quebec 
have not been as ethnocentric as the ones in Brisset's corpus (Gagnon

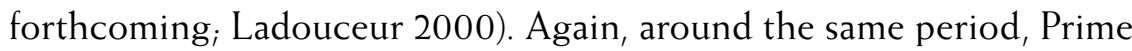
Ministers Brian Mulroney and Jean Chrétien claimed with much conviction their pride in their Canadian identity, and particularly in the French versions of their speeches. These similarities further suggest that the Quebec nationalist discourse and the Canadian nationalist discourse are evolving at the same pace, and greatly influence each other.

That translation has been used throughout history as a vehicle for ideologies is beyond question. What this paper has shown is that it is important to understand how this has been done and what the repercussions of such ideological dissemination are. This in turn will eventually lead to a better understanding of both translation history and national histories.

CHANTAL GAGNON

Aston University

(United Kingdom)

\section{Notes}

1. Many thanks to Christina Schäffner and Stefan Baumgarten for commenting on an earlier draft of this paper. Any remaining errors or omissions are, of course, entirely our own.

2. For more insight on these crises, and on Canadian History in general, see The Oxford Companion to Canadian History (Hallowell 2004).

3. We are grateful to Christina Schäffner and José Lambert for the enlightening discussions we engaged in concerning Chesterman's taxonomy.

4. Much has been written on the concept of "adaptation" in translation studies. It is not our intention to review this concept in depth, but rather to use it as a working concept for our test case study. 


\section{References}

Primary sources

Canada, Prime Minister. (1942a). Speecb by Rigbt Honourable W. L. Mackenzie King, MP, Prime Minister of Canada, on Overseas Service in the Canadian Army Amendment of the National Resources Mobilization Act, Delivered in the House of Commons on Wednesday, June 10, 1942. Ottawa: Edmond Cloutier, King's Printer.

. (1942b). Discours prononcé par le très Honorable W. L. Mackenzie King, MP, premier ministre du Canada, à la Chambre des communes, le mercredi 10 juin 1942 sur le sens de l'amendement au sujet du service militaire outre-mer. Ottawa: Edmond Cloutier, King's Printer.

- (1942c). National Unity and National Survival, Responsibility to Our Own and Future Generations, A Second Appeal to the Canadian Electorate for an Affirmative Vote on April 27: An Address. Delivered by Prime Minister William Mackenzie King. Ottawa: King's Printer.

(1970a). Notes for a National Broadcast by the Prime Minister, Friday, 16 October, 1970. Release. Delivered by Prime Minister Pierre Elliott Trudeau. Ottawa: Office of the Prime Minister.

. (1970b). Notes pour un message du Premier ministre à la nation, vendredi, le 16 octobre 1970. Release. Delivered by Prime Minister Pierre Elliott Trudeau. Ottawa: Office of the Prime Minister.

(1976a). Transcription of the Prime Minister's Address on National Television and Radio, November 24, 1976. Release. Delivered by Prime Minister Pierre Elliott Trudeau. Ottawa: Office of the Prime Minister.

. (1976b). Transcription du discours du premier ministre à laradio-télévision nationale, le 24 novembre 1976. Release. Delivered by Prime Minister Pierre Elliott Trudeau. Ottawa: Office of the Prime Minister.

. (1980a). Statement by the Prime Minister in Response to the Quebec Referendum Vote, May 20, 1980. Release. Delivered by Prime Minister Pierre Elliott Trudeau. Ottawa: Office of the Prime Minister. Reproduced with the permission of the Minister of Public Works and Government Services Canada, 2005, and courtesy of the Privy Council Office (2005-15352D).

- (1980b). Déclaration du premier ministre Pierre Elliott Trudeau le soir du référendum québécois, le 20 mai 1980. Release. Ottawa: Office of the Prime Minister. Reproduit avec la permission du Ministre des Travaux publics et Services gouvernementaux Canada, 2005, et gracieuseté du Bureau du Conseil privé (2005-15352D).

. (1990). Notes for an Address to the Nation by Prime Minister Brian Mulroney, Ottawa, June 23, 1990; Notes pour une adresse à la nation du premier ministre Brian Mulroney, Ottawa, le 23 juin 1990. Release. Ottawa: Office of the Prime 
Minister. Reproduced with the permission of the Minister of Public Works and Government Services Canada, 2005, and courtesy of the Privy Council Office (2005-15352B).

. (1995a). Address to the Nation by Prime Minister Jean Cbrétien, October 25, 1995

- Message à la nation du premier ministre Jean Cbrétien, le 25 octobre 1995. Release.

Ottawa: Office of the Prime Minister. Reproduced with the permission of the Minister of Public Works and Government Services Canada, 2005, and courtesy of the Privy Council Office (200515352A).

. (1995b). Statement by Prime Minister Jean Cbrétien, Ottawa, October 30, 1995

- Déclaration du Premier ministre Jean Cbrétien, Ottawa, le 30 octobre 1995. Release.

Ottawa: Office of the Prime Minister. Reproduced with the permission of the Minister of Public Works and Government Services Canada, 2005, and courtesy of the Privy Council Office (2005-15352C).

(25/4/1942), 6-7.

25.

. (1942b)."Texte du discours du très hon. M. King." La Presse (25/4/1942),

\section{Secondary sources}

Al-Harrasi, Abdulla Nasser Khalifa. (2001). Metaphor in (Arabic-into-English) Translation with Specific Reference to Metaphorical Concepts and Expressions in Political Discourse. Unpublished Ph.D. Thesis. Birmingham: Aston University.

Baumgarten, Stefan. (2001). "Uncovering Ideology in Translation: An Analysis of English Translations of Hitler's Mein Kampf." CTIS Occasional Papers, 1, $21-54$.

Bourque, Gilles, and Jules Duchastel. (1996). L'identitéfragmentée, Nation et citoyenneté dans les débats constitutionnels canadiens, 1941-1992. Avec la collaboration de Victor Armony. Montréal: Fides.

Brisset, Annie. (1990). Sociocritique de la traduction, théâtre et altérité (1968-1988). Longueuil: Préambule.

Brown, Penelope, and Stephen C. Levinson.(1978). "Universals in Language Usage: Politeness Phenomena." In Questions and Politeness, ed. Esther Goody. Cambridge: Cambridge University Press, 256-289.

Calzada Pérez, María. (2001). "A Three-Level Methodology for DescriptiveExplanatory Translation Studies." Target, 13:2, 203-239.

Charron, Marc. (1997). "'Demain tout recommence': Lord Durbam's Report en traduction." TTR, 10:1, 101-136.

Chesterman, Andrew. (1997). Memes of Translation, The Spread of Ideas in Translation Theory. Amsterdam and Philadelphia: John Benjamins. 
Chesterman, Andrew, and Rosemary Arrojo. (2000). "Forum: Shared Ground in Translation Studies." Target, 12:1, 151-160.

Chilton, Paul. (1997). "The Role of Language in Human Conflict: Prolegomena to the Investigation of Language as a Factor in Conflict Causation and Resolution." Current Issues in Language and Society, 4:3, 174-189.

Chilton, Paul and Christina Schäffner. (2002). "Introduction: Themes and Principles in the Analysis of Political Discourse." In Politics as Text and Talk: Analytic Approaches to Political Discourse, eds. Paul Chilton and Christina Schäffner. Amsterdam and Philadelphia: John Benjamins, 1-44.

Delisle, Jean. (1993). La traduction raisonnée, manuel d'initiation à la traduction professionnelle de l'anglais au français. Ottawa: Presses de l'Université d'Ottawa.

Delisle, Jean, Hannelore Lee-Jahnke, and Monique C. Cormier, eds. (1999). Translation Terminology. Amsterdam and Philadelphia: John Benjamins.

Duchastel, Jules, and Victor Armony. (1993). "Un protocole de description de discours politiques." Actes des secondes journées internationales d'analyse statistique de données textuelles. Paris: Télécom, 159-183.

Fairclough, Norman. (1989). Language and Power. London: Longman.

. (2003). Analyzing Discourse, Textual Analysis for Social Research. London and New York: Routledge.

Gagnon, Chantal. (2002). Les enjeux sociotraductologiques et idéologiques de deux grands discours traduits de René Lévesque et de Pierre Elliott Trudeau. Unpublished MA thesis. Montréal: Concordia University.

. (2003). "Institution in Translated Political Speeches: A Canadian Example," In Camling 2003, Proceedings of the University of Cambridge First Postgraduate Conference in Language Research, 26 April 2003, eds. Damien Hall, Theodore Markopoulos, Angeliki Salamoura, Sophia Skoufaki. Cambridge: University of Cambridge, 433-439.

(Forthcoming). "Le Shakespeare québécois des années 1990." Recherches théâtrales au Canada.

Godin, Pierre. (2001). René Lévesque, l'espoir et le chagrin, (1976-1980). Montréal: Boréal.

Goffman, Erving. (1967). Interactional Ritual. New York: Doubleday.

Hallowell, Gerald, ed. (2004). The Oxford Companion to Canadian History. Oxford: Oxford University Press.

Hatim, Basil. (1991). "Coping with Ideology in Professional Translating." Interface, Journal of Applied Linguistics, 6:1, 23-32.

and Ian Mason. (1997). The Translator as Communicator. London and New York: Routledge.

Ladouceur, Louise. (2000). "Made in Canada: le théâtre canadien-anglais au Québec."Québec français, 117 (spring), 71-73.

Íñigo-Mora, Isabel. (2004). "On the Use of the Personal Pronoun We in Communities." Journal of Language and Politics, 3:1, 27-52. 
Molina, Lucía, and Amparo Hurtado Albir. (2002). "Translation Technique Revisited: A Dynamic and Functionalist Approach." META, 47:4, 498-512.

Mossop, Brian. (Forthcoming). "Reader Reaction and Workplace Habits in the English Translation of French Proper Names in Canada." META.

Schäffner, Christina. (1997). "Where is the Source Text?" In Modelle der Translation. Models of Translation, Festschrift für Albrecbt Neubert, eds. Heide Schmidt and Gerd Wotjak. Frankfurt: Vervuert, 193-211. . (2003). "Third Ways and New Centres, Ideological Unity or Difference?" In Apropos of Ideology, Translation Studies on Ideology — Ideologies in Translation Studies, ed. María Calzada Pérez. Manchester: St. Jerome Publishing, 23-41.

Struever, Nancy S. (1985). "Historical Discourses." In Handbook of Discourse Analysis, ed. Teun A. van Dijk. Vol. 1. London: Harcourt Brace Jovanovich, 249-272.

Van Dijk, Teun A. (1998). Ideology, a Multidisciplinary Approach. London: Sage Publications.

Venuti, Lawrence (1995). The Translator's Invisibility - A History of Translation. London and New York: Routledge. 


\section{Appendix 1: Chesterman's modified taxonomy}

\section{SYNTACTIC SHIFTS \\ (MANIPULATE THE FORM)}

Literal translation (close to the $\mathrm{SL}$ form)
SEMANTIC SHIFTS

(MANIPULATE THE MEANING)

Synonymy (not the "obvious" equivalent)
PRAGMATIC SHIFTS

(MANIPULATE THE MESSAGE)

Adaptation (sociocultural reality from SL replaced with a reality specific to the $T L$ )
Loan, calque (borrowing items from another language)
Antonymy (using a negation element)
Explicitness change (explicitation/implicitation)

\begin{tabular}{|c|c|c|}
\hline $\begin{array}{l}\text { Transposition (word-class } \\
\text { change) }\end{array}$ & $\begin{array}{l}\text { Hyponymy (superordinate - } \\
\text { hyponym) }\end{array}$ & $\begin{array}{l}\text { Information change (addi- } \\
\text { tion, omission: cannot be } \\
\text { inferred) }\end{array}$ \\
\hline $\begin{array}{l}\text { Unit shift (units are: mor- } \\
\text { pheme, word, phrase, clause, } \\
\text { sentence, paragraph) }\end{array}$ & $\begin{array}{l}\text { Converses (same state of } \\
\text { affairs from opposing view- } \\
\text { points, as in "buy-sell") }\end{array}$ & $\begin{array}{l}\text { Coherence change (logical } \\
\text { arrangement of infor- } \\
\text { mation, often paragraph } \\
\text { change) }\end{array}$ \\
\hline $\begin{array}{l}\text { Phrase structure (number, } \\
\text { definiteness, person, tense, } \\
\text { mood) }\end{array}$ & $\begin{array}{l}\text { Abstraction change (from } \\
\text { abstract level to concrete } \\
\text { level, or from concrete level } \\
\text { to abstract level) }\end{array}$ & $\begin{array}{l}\text { Partial translation (sum- } \\
\text { mary, transcription, } \\
\text { symbolist translation) }\end{array}$ \\
\hline $\begin{array}{l}\text { Clause structure change } \\
\text { (order, active/passive finite- } \\
\text { ness, transitivity) }\end{array}$ & $\begin{array}{l}\text { Distribution change (expan- } \\
\text { sion or compression of } \\
\text { semantic components) }\end{array}$ & $\begin{array}{l}\text { Visibility change (footnotes, } \\
\text { comments, glosses) }\end{array}$ \\
\hline $\begin{array}{l}\text { Sentence structure change } \\
\text { (main / subordinate clause } \\
\text { changes) }\end{array}$ & $\begin{array}{l}\text { Emphasis change (adds to, } \\
\text { reduces, or alters the } \\
\text { emphasis or thematic focus) }\end{array}$ & $\begin{array}{l}\text { Transediting (tidying badly } \\
\text { written parts or whole texts) }\end{array}$ \\
\hline $\begin{array}{l}\text { Cohesion change (intra- } \\
\text { textual reference, ellipsis, } \\
\text { substitution, pronominaliza- } \\
\text { tion, repetition) }\end{array}$ & $\begin{array}{l}\text { Paraphrase (disregard of } \\
\text { semantic components in } \\
\text { favour of pragmatic sense, } \\
\text { typical strategy for idioms) }\end{array}$ & $\begin{array}{l}\text { Other pragmatic changes } \\
\text { (layout, choice of dialect) }\end{array}$ \\
\hline $\begin{array}{l}\text { Level shift (levels are phonol- } \\
\text { ogy, morphology, syntax and } \\
\text { lexis) }\end{array}$ & $\begin{array}{l}\text { Trope change (change in } \\
\text { rhetorical tropes/figurative } \\
\text { expressions) }\end{array}$ & \\
\hline $\begin{array}{l}\text { Scheme change (changes in } \\
\text { rhetorical schemes: paral- } \\
\text { lelism, repetition, allitera- } \\
\text { tion) }\end{array}$ & $\begin{array}{l}\text { Other semantic changes } \\
\text { (change of physical sense/ } \\
\text { deictic direction) }\end{array}$ & \\
\hline
\end{tabular}


This page intentionally left blank 


\section{Keepers of the Stories}

The Role of the Translator in Preserving Histories

M any Canadian readers are familiar with early Aboriginal literature - even that which was produced up until the middle of the last century - only through the "myths and legends" included in school textbooks and anthologies. Although several contemporary Aboriginal writers (many of whom write in English as well as an Aboriginal language, or write exclusively in English) have now claimed a place in English Canada's literary canon, very few contemporary nonAboriginal translators approach the early oral literature of the First Nations as anything but a collection of folktales without authors or as examples of the primitive. Robert Bringhurst is a clear exception. His work in translating the master mythtellers of past centuries cannot fail to convince us that literary history needs to be rewritten as well as reread, that just as contemporary European writers can look back to ancient Greek and Roman texts for the roots of genre or form, so also can North Americans trace poetry and fiction back to a classical Aboriginal artistic tradition as rich and varied as European music or 
painting. His books integrate poetic translations, retellings of stories and poems transcribed by one ethnographer at the turn of the last century, with exhaustive research on the nature of the civilizations which produced the founding traditions of North American literature - their languages, their artwork, their literatures. In A Story as Sharp as a Knife (Bringhurst 1999), for instance, he presents over five hundred pages of writing on Haida mythtellers, including more than one hundred pages of notes and appendices. The result is that the literature, rather than being fragmented and decontextualized, is returned to its source culture and examined there, where it belongs and takes on its full meaning, in careful, thoughtful scholarship.

This paper addresses the importance of Robert Bringhurst's work in the context of the history of Aboriginal languages and literature in Canada. The comments presented here focus on some fundamental attitudes that can help translators to understand and to use approaches that ensure the preservation of artistic works and narratives of endangered cultures through translation.

In other research (Elder 2003b and 2003c), I have described some of the roles that translators have played in shaping Canadian culture. As "ambassadors" - sociopolitical agents - academics, and artists or writers, literary translators have contributed to literary history in a wide variety of ways. Through their translations of works that are otherwise not available to or known in the target language, translators have enabled librarians and booksellers to stock their shelves, critics and journalists to fill pages of print, teachers and professors to present the other culture to their students, readers to have access to innovative ideas and practices, and so on.

On the whole, however, while a translated text can generate a number of subsequent metatexts, literary scholars sometimes ignore the influence that literary translators can have, first, on individual creators in the source culture and the target culture, and second, on both literary and social history. In both cases, we often privilege discourse over action and the life of the mind over the real. Robert Bringhurst's work encourages us to view the impact a translator can have on the course of 
lived history; moreover, it suggests a translator contributes to history by recording and translating texts written in an endangered language, the expressions of a culture that might (otherwise or still) be lost. Beyond making a contribution to the literary history of the target culture, translated texts have a transformative impact, they change the course of history in unpredictable ways.

\section{Robert Bringhurst and human literary history}

In his moving lecture to the International Federation of Translators, in Vancouver (2002), Robert Bringhurst said, "What I need as a human being is a picture of the whole of human history. What I need as a practising writer is a picture of the whole of human literary history." His paper is of obvious relevance to the theme of this collection of papers, and his title evokes this thematic: "The Future of the Past: Translating Native American Literature into Colonial Tongues."1 Although it is Bringhurst's work as a translator of Haida Gwaii oral literature that primarily interests me in this study, Bringhurst positions himself in the introductory remarks of his article as a writer. For this reason, and because of the multiple roles literary translators play in shaping history, I want to consider what his translations add to many histories: those of translation, of literary practices, of languages, of culturality and what could be termed the history of humanity. ${ }^{2}$

Translators don't always do so, but they may ask themselves some questions of the most fundamental order: for whom, why does one translate? Who has actually translated what, for whom and how? This paper will present different perspectives on the influence of Robert Bringhurst's work on creators and readers, in an attempt to break down some of the cultural generalizations that are hard to resist when we attempt to look at the real under the lens of translation studies. As well, it will cast a passing glance at the reciprocal influence of literary translation and other artistic fields. The aim is to put the body of work created by Bringhurst and other writer-translators into a larger historical context and to remind us that literary translators are practising artists, 
that their work needs to be examined as literature, and not simply as texts documenting cultural history.

Having considered interactions of history and translation, we know there is great value in adding the stories that Bringhurst has set into circulation through his translation to literary history. However, he specifies that he needs - and the articulation of need is also rich - buman literary history. In part, his use of the term human history refers to the importance of people's history or "la petite histoire." His phrase "the whole of human literary history" certainly suggests the need for inclusivity. However, the implication of human history goes beyond a need to inscribe the work of minority writers and "particularist" texts into a larger whole of literary history. ${ }^{3}$ His translations have an impact on the lives of individuals and collectivities who speak the source language as well as the target language.

\section{The translator's body of work}

Bringhurst's modesty is one of the things that has contributed to the fact that his translation work, as a whole, has not been examined carefully. In any case, the work of writer-translators does not generally receive the sustained attention of scholars or critics. Certainly the creative process of a literary translator, so similar to that of a writer in any genre, is not often discussed. Different translators approach their work in different ways, emphasizing one or another aspect not only in one work, in a strategy of preserving the integrity of the work, but often in many works they translate. Translators may work closely with one author, adopting and adapting similar practices; they may prefer a school, period or group of writers, or they may sustain particular stylistic approaches, for instance preferring Latinate forms to Germanic alternatives or focussing on cadence, as the late Fred Cogswell often did, or rather attempt to reconstruct the creative process of the author and re-establish patterns of repetition, word-play, images, and the like, as I do. ${ }^{4}$

Translation is one of the best ways to bring new life to old literary traditions, but the line between original writing and imported transla- 
tions seems to be almost as impermeable as some of the other dams we build around our notions of art and literature. A figure like Robert Bringhurst challenges several of these notions, and this is not only because challenges are inherent in the academic perspective into which translations fall, being subject to distinct modalities of reception. When a translation becomes popular, the fact that it is a translation and/or an importation is generally erased by canonical streamlining techniques. ${ }^{5}$ That Robert Bringhurst's translation work is widely known outside of translation circles and remains read as a translation is therefore of interest to those interested in reception patterns. On the other hand, Bringhurst's authorship is equally highlighted; because of his research and the fact that his translations of several writers appear together in $A$ Story as Sharp as a Knife, for instance, his name is the only one on the cover. Immediately, though, the names of the Haida storytellers appear in the text, those names almost entirely lost to human memory. Bringhurst is the writer who has taken down and studied the literature of the "classical Haida mythtellers." In a sense, he is creating the history he is documenting. Moreover, the combination of popularity and erudition in Bringhurst's work pushes Canadian culture's tendency to merge popular and critical audiences to an extreme.

Because Bringhurst was first known as a poet, the reader may ask why he would have chosen to translate Haida Gwaii myths. In other places and periods, however, translation is recognized as being a way for a writer to develop new practices in his own creative work, as well as adding new forms to the literary traditions of the target culture, thereby influencing literary history in multiple ways: by introducing source texts and writers into target culture, influencing writers in the target culture, putting ideas and cultural references into circulation in the target culture, and both circulating different (and therefore new) literary practices and developing new ways of translating literature, since each work demands a slightly different approach.

One of Bringhurst's accomplishments is in asserting the role of the translator as writer and the writer as translator. This changes, sensibly, his position in history, by presenting literary history as one in which the 
translator plays a fundamental role, and one which is interrelated but not interchangeable with the history of ideas.

\section{Reshaping, restoring, retrieving histories}

In both literary history and the history of ideas, Bringhurst's work challenges perceptions. Who is translating, who is speaking for whom? Whose ideas are these, and what is the relationship between culturality, spirituality and the imaginary? How much of each is preserved, rendered, created in translation? What is the source of the source text? The translations are not imported, but neither are they transferred between the official languages. Far from migrant, far from another land, this is the literature of our own first peoples. His work contradicts what we believe about the domestication and popularization of translation, and about the parallel models of Canadian culture.

Bringhurst's work in translation implicitly articulates the value of translation in terms of survival: the importance of keeping the stories, the language, the culture alive. His translations can be seen as an act of preservation, a rescue. The threat of disappearance is never too far from the mind of the translator as he performs his work. And the threat is, perhaps, more real than we care to think.

One of the gravest threats to this picture of human literary history that Bringhurst says he needs, and that we all need as human beings, is the loss of languages, literatures and cultures. The threats are not simply those of waning interest, prestige, transmission from one generation to the next or the ability to communicate with a larger number of people. When a language is threatened and a culture is marginalized, when a group of people do not have access to power or privilege, these losses are often accompanied by lost and missing lives. The tellers of the stories, their ways of telling, are threatened by the same things that threaten language: war, conquest, genocide, extinction, holocaust. When one group exerts cultural dominance over another, there are also threats to individual freedom and security: assimilation, censorship, tyranny and simple ignorance. We have only to think of the execution 
of individual translators to be reminded that the invisibility of the translator has signficance beyond the conventional and academic or rhetorical questions we examine in articulating intellectual and literary history.

Bringhurst's approach to history is that it is "a problem - one that translation could help to clarify, and possibly even to solve." (11) In contrast, he states that, for him, translation "has always been a method of exploration: less a way of solving problems than of trying to find out roughly what the problems are." (11) His translations may be solutions, but they are possible solutions to the challenges of history rather than of language. But among the problems of history are the ways it annihilates languages and eliminates stories. Translators keep the old stories, bring them to new eyes, create a new gaze to see old relics and dead bodies, and make stories new again. Bringhurst points out that when the European invasion began, about five hundred different languages were spoken in the Americas, including approximately sixty-five in what is presently Canada. (12) This reminder is an appropriate one as New Brunswick celebrated, in 2004, the four hundredth anniversary of the arrival of the Europeans to Wabanaki (which will be followed by 2005 's commemoration of the two hundred and fiftieth anniversary of the Deportation). It suggests that we all have a role to play in preserving the languages and cultures of our First Nations peoples as well as the two official languages. Preserving may be the wrong word, however. "Languages . . . are not static," writes Robert Bringhurst. "They are born and die, like species of plants and animals. They also move around, and sometimes they get pushed around, and sometimes they are pushed to the brink of extinction." (12) The statement may sound matter of fact, but Bringhurst's statement is accompanied by a dramatic illustration. He points out that in a large section of the map that illustrates his paper there is a white space, where languages died before any written record was made. The blank record is a rich image, evoking sterility and absence. It does not, however, convey the blackness of death or evil, or the drops of red, marks of the indigenous, the feminine, and the loss of human life. 
Keeper of the language

Keeping languages alive is a matter of protecting the people who speak them. The safe-keeping of stories, spiritual teachings, sacred objects is essential to the protection of First Nations peoples. Bringhurst presents the role of the translator in phrasing that is not inconsistent with the First Nations' view of cultural exchange. "When I [translated], I relished every instant of the labour and felt that the gift I had been given, the experience I'd gained, was greater than whatever I had given in return." (11) In this way, he can be understood as being the "ideal reader" and thus the ideal translator of First Nations literature.

Bringhurst brings to his translations of Haida Gwaii texts respect, understanding of the spiritual meanings of words, and the recognition of the value of the gift he has been given. Without these, translators can only add to the white spaces between unidentified bodies and unheard voices.

By writing down and translating stories, translators give voice to individual people who are otherwise silenced, marginalized, and excluded. They find, retrieve, rescue, and revive stories and poetry that lie outside of our literary and historical traditions, as well as the practices and aesthetics that make them literary texts. But rather than simply preserving culture, they are also keeping people alive. Without stories, languages and then cultures disappear. A diminished culture takes down with it individual victims of problems of health, abuse, and despair. Unless a people is creating its own artwork, telling its own stories, writing its own literature, it will disappear.

While academics and critics warn against theft or appropriation by a dominant culture, Bringhurst suggests that allowing a literature or a language to die out is a far more serious loss.

The best way to steal a people's history, culture and language is by not trying to learn it, replacing it blindly with a history, culture and language of your own. Learning someone's language, someone's culture, someone's history, reinforces it. It is not an act of theft ${ }_{i}$ it is an act of recognition and acknowledgement, like learning someone's name. It's 
an indispensable act of respect - for societies and for individuals too. (Bringhurst 2006, 20)

A translator who learns to read or communicate with artists in their language is working against assimilation in various ways. Bringhurst's translations offer creative ways of restoring and preserving elements of the source text, by textualizing recognition and respect. In A Story as Sharp as a Knife, for instance, he not only compares the Haida poet Ghandl to Homer and the author of Beowulf, but he provides copious notes and explanations about the importance of the contributions to literary history made by the Haida Gwaii writers he has selected. Even presenting and translating as "oral narrative poems" (ibid., 27) a body of work so often dismissed as "myths and legends" emphasizes the literary value of the text rather than its importance as a document. Then, in the presentation of Skaay's "Sleek Blue Beings," Bringhurst enters from time to time as a respectful member of the audience, a receiver of spiritual knowledge, rather than an originator:

[Skaay] was unfolding his own vision of the world by speaking in mythological terms ... Words are a means of rediscovery and rebirth instead of repetition. Skaay continues now, from where we interrupted him (Bringhurst 1999, 242).

As mentioned earlier, the fact that the name of the mythteller is given is important; authorship is attributed to the teller, here. And even more significant perhaps is Bringhurst's decision to provide names for places and people in the Haida language. As Bringhurst acknowledges:

... except in a few cases where I know the individuals or their communities would disapprove, I use people's indigenous personal names: Skaay instead of John Sky; Daxhiigang rather than Edenshaw; Kilxhawgins, not Abraham Jones. I know most readers of the book will find the Haida and other native names harder to spell, remember and pronounce $(1999,17)$. 
But the reason is more than a desire to foreignize. It is, instead, "an essential gesture of respect and recognition - one I hope most readers of this book will also want to make" (Bringhurst 1999, 242). Through the use of this authorial voice, Bringhurst takes the classical translator's preface and elaborates a scholarly discourse. But this ethnography is, literally, a "wellversed" approach, clearly subordinate to poetics and linguistics.

As well as using this scholarly voice to help the reader learn the language, Bringhurst also does so through lengthy footnotes about the nuances of meaning and the historical backdrop of the story being told. Haida text is included and examined. For instance, on page 251, Bringhurst provides the Haida text and the literal translation of a passage, preserving the syntax and compound words. This gives us: "Then * thus $*$ him * he * talking-acting * him-to $*$ he $*$ grasping-handling-the * when / Me ${ }^{*}$ here** are. / That-there * too * you * are." It is obviously a foreignizing strategy, and Bringhurst's intentions seem to go beyond the dépaysement of the reader. He wants to teach them how to read not only this ancient language but the way translation works. He continues, "This, again, is the working translation: As he handed him these, he said to him, / "You are me. You are that, too." (ibid., 252). "Again," because Bringhurst has presented these lines a few pages earlier. The reader is called to be a listener (this is Bringhurst's description, in his opening words, of what he has done as a scholar and translator). There is repetition, both in an incantatory tone to echo the storytelling, and in a didactic mode to remind us about what we are doing and what the language is doing. The passage Bringhurst chooses to expound on the "stylistic idiosyncracies" of Skaay seems to me to be one of incredible complexity. (251) For, after all, we are the listeners, as Bringhurst is the listener, and, at the same time, we are the actors and perhaps even the mythtellers of our own lives. "You are me. You are that, too." And the "that" (later, "those are the things of which he was speaking") invites us to explore, to come to our own conclusions: are "those" ravens, or something more, something of another world? Bringhurst, as translator, prefers to lead us through deeper levels of complexity rather than to provide a fixed, clear meaning. 
Bringhurst recognizes the position in which he is placed, the potential for harm and damage that can be done when a recording is transcribed, capturing a telling and freezing it in time, and he reminds us of our position outside of these cultures. Another of his textual strategies is to create incantatory repetitions, such as using "they say" at the end of sentences several times throughout a long work to remind us that this is an oral performance and that it is someone else who is speaking. The translator is placed in the position of listener, but then listeners may tell the story anew. Each telling, each translation is different. Bringhurst presents translation, like history, as a dilemma: "I propose, in keeping that principle, a simple two-part thesis — or dilemma, as you please: 1. There is nothing that can be translated perfectly, but 2 . There is nothing that cannot be translated."

\section{Keeping the stories safe}

The translation needs to remain a work foreign, in important ways, to our experiences. It is up to us to stretch to understand, and not up to the translator to tell us. Bringhurst writes, ". . . there is a sense in which, even to read or hear the translation, you still have to learn another language." Later, addressing the idea of appropriation (or translation as genocide) (14), he talks about the protective effects of foreignizing ourselves:

Instead of translating from the Navajo, we must translate ourselves into Navajo. We should not be 'anglicizing' the works but 'navajoizing' their potential readers. That in fact is what genuine translators and translations tend to do (Bringhurst 2006, 21).

Developing the capacity to become readers (or listeners) of these translations is a demanding task. Our familiarity with work by First Nations and writers from other cultures often comes first from anthologies, which removes the works from context but also from the voice of the individual writer. Bringhurst considers that textbooks and anthologies 
transmit stereotypes and give no "sense of the enormous and creative contribution that individual mythtellers ... make to their own traditions" (17). The stylistic and aesthetic choices made by Bringhurst do not facilitate a straightforward reading of the text, but rather present themselves as signposts of the distance between the source and target cultures.

One of the elements that Bringhurst is determined to preserve in his translation is what he calls the "animatedness" of the work. Everything is alive, everything is personified. Looking at the roots of "animated" (16) — breath and life, of course, but also spirit — it is easy to see the similarity of Bringhurst's mission to that of the first translators of the Bible. The spiritual dimension of the artist's work presents it as a mission - but of preservation of the belief system rather than of conversion.

Another point that Bringhurst makes is about the interconnectedness of forms of art. He writes, "Strange as it may sound, I think that, for outsiders, maybe the best preparation there is for learning to listen to the masterworks of classical Haida literature is learning to listen to European classical music." Later, he likens oral literature to jazz and painting. Earlier, he suggested looking at sculpture as a preparation for listening to myths. ${ }^{6}$ By writing down the stories and translating the literature of other cultures, however, translators not only enable other artistic traditions to survive and even flourish, they also keep them safe from extinction. Whether the texts and tales be those of the indigenous people in Canada or of "others," including those writers who have immigrated because of intolerable conditions and those who continue to live under the threat of death, the act of preserving literature is a gesture not unlike providing shelter or amnesty. The act of literary translation is a small but significant gesture towards the continuance and furtherance of peoples in danger of being eliminated, towards the survival of people whose lives, as well as whose work, may be lost to us, whether because of the grand tragedies of History or through the neglect and exclusion of the individuals whose lives make up the people's history.

As we look at the future of history, we are struck by the climate of the times in which we live, in which change is occurring rapidly and more and more of the "natural" remnants of culture are being destroyed by, for 
instance, new media, globalizing technologies, conflicting rights, and the figurative and literal closings of borders. In such a climate, certain forms, practices and words become threatened by and threatening to dominant culture. The translator is placed on a bridge that could be blown up at any moment, and must choose whether to render the unspeakable, discover ways to translate the untranslatable, and endeavour to give voice to the silent and the silenced.

The reasons we are called to translate are no more trivial than this: we translate to preserve life and history. Bringhurst writes,

The clearest and most universal reason to study and translate Native American oral literature is that it's part of the human testament, part of the accumulating map of the human mind and the human experience, part of our own species' natural history. For many of us, though, there is a further reason, found in the conjunction of self and subject: this is the place where we were born. (Bringhurst 2006, 20)

Robert Bringhurst's work can have consequences that we can only begin to imagine. In reading his translation of these poetic stories, in which the threat of loss is articulated textually as well as paratextually, we cannot help but be reminded that we are living in times that are hard to understand, in which the artist's voice seems to fall silent or on deaf ears. More importantly, the dimensions of horror are such that governments try to ban photos of bodies and the media censors our television screens.

If these acts were in the interest of preventing us from being desensitized, or to protect the privacy of the individual victims, they could be viewed with less skepticism. Human rights activists have made it clear, however, that we need to know. We need more information, more contact, more freedom of movement and speech, more access - not to information as much as to ways of understanding what the seemingly discrete and bizarre catastrophies might mean at some level that at once connects us and welcomes our differences.

The suggestion that the work of art is alive, animated, reminds us 
that it comes from the physical gestures of a creator who is or who has been alive. These stories are the expression of a person, as well as of a people. The humanity of the original creator, while protected by Bringhurst's discretion and respectful difference, is one of the essential guidelines of Bringhurst's translation work. It seems to me that it is the relationship between the author and the translator that is the greatest indicator of whether the culture is being preserved or appropriated. Protect the storyteller, respect the keeper, and the stories will also be safe from harm. This also implies that appropriation is simply another metaphor, and a diminished one, for the loss and neglect of human life. Our academic and pedagogical attention to questions such as authority and plagiarism needs to be informed by a recognition — by our recognition - that there are greater, more desperate and more urgent issues to be resolved in our real, individual lives.

Work from another culture that lies beyond the limits of our understanding needs to be brought into our range of vision through a series of literary practices and a base of understanding. At the same time, as Doris Sommer (1999) and other specialists of particularist writing remind us, we should not simply assume that this work is meant to come into our grasp, that we are entitled to have access to it. As readers, as writers, we, like the translator evoked but not described by Bringhurst, are here to bear witness to that which would otherwise remain invisible through neglect rather than through mindful protection. Bringhurst writes that what is missing from many versions, many false testimonies, is what he calls translation, "the honesty and fidelity that translators are duty-bound to provide." (20) This false testimony, this stolen and misunderstood knowledge, is what is really theft and broken promises.

Although I am certain that it is not his intention or even his hope Bringhurst is an artist, and not an ambassador or a spokesperson - his work has the result of preserving, rendering and creating humanity. The reader and the writer who are moved by his work are not only creating meaning, they are also becoming more human.

JO-ANNE ELDER

Fredericton, N.B. 


\section{Notes}

1. Robert Bringhurst. (2006). "The Future of the Past: Translating Native American Literature into Colonial Tongues". In ellipse: Canadian Writing in Translation, no. 76, Winter 2005-06). All references to this article are included in the text.

2. Among Bringhurst's translations of First Nations (oral) literature are A Story as Sharp as a Knife: The Classical Haida Mythtellers and Their World (Bringhurst 1999) and The Raven Steals the Light (Bringhurst and Reid 1984), which is only in part a translation. He wrote this book in 1984 with Bill Reid, who was a bilingual (and biracial) Haida-English artist. Bringhurst also translates from classical languages, and intersperses various languages in his own poetry.

3. The term "particularist" is taken from and defined according to the important work of Doris Sommer in Proceed With Caution, When Engaging Minority Writing in the Americas (Sommer 1999).

4. In my introduction to Ellipse issue number 68, dedicated to Fred Cogswell's work, I cite the example of apostrophes ("labyrinth's heart") and hyphens ("sea-wind") used by Cogswell in both writing and translating in order to preserve the cadence. (8). An example of my own concern for preserving repetitions is the fact that I tend to translate a word by the same English word whenever possible ("regard" by "gaze" throughout a work) rather than using alternatives ("look," "glance," or something similar). I also try to work as the author does, whether it is in translating ten verses a day when the author has written ten, or translating an entire collection if the first draft was written quickly.

5. This is very true of translations of Quebec literature, such as those of Gabrielle Roy's, Roch Carrier's and Michel Tremblay's works, which have become part of "English" Canada's literary canon. "The history of translation should go further. It should also find a place for non-Canadian texts that have become, to a certain extent, part of Canada's literary polysystem" (Blodgett 1983, 28). Often, modifications are made to render possible the entry into the canon; they include, of course, various methods of erasing the marks of the translation, both through the manipulation of the language and the practice of reading translations (see Venuti 1995).

6. "Every accomplished performance is a reinvention of the work. In this respect, Native American oral literature is a lot like another kind of music. It's a lot like jazz. You can write a new jazz tune if you want to, but if it's any good, it will sound as if it's old. And there is no great need to write new tunes, because, of course, there is an infinite number of unexhausted ways to play the tunes we already have. And almost any tune can be converted into jazz if a jazz musician plays it. . . European painting worked this way as well, in its greatest days, during the Renaissance and the Baroque. In those 
days, European painting was primarily a means of retelling and revitalizing myths. No one asked Bellini or Mantegna or Michelangelo or Titian to invent a new story" and "if you've grown up in the world of European or Asian literature, you have to learn the language of Native American narrative, and some of the language of Haida culture. . . " (16). "And it will help, of course, to look at some Haida art. A lot of lovely works of sculpture from these villages are now on display in museums in Vancouver and Seattle, Ottawa and Washington, New York, Paris, London and Berlin" (14). Bringhurst (2006)

\section{References \\ Primary sources}

\section{PUBLISHED SOURCES}

Bringhurst, Robert. (1995). The Calling: Selected Poems, 1970-1995. In The Modern Canadian Poets. Toronto: McClelland \& Stewart.

(1999). A Story as Sharp as a Knife: The Classical Haida Mytbtellers and Their World. Vancouver/Toronto: Douglas \& McIntyre.

. (2006). "The Future of the Past: Translating Native American Literature into Colonial Tongues." In ellipse: Canadian Writing in Translation, no. 76, Winter 2005-2006, 11-22.

Bringhurst, Robert, and Bill Reid. (1984). The Raven Steals the Light. Vancouver/ Toronto: Douglas \& McIntyre.

Bringhurst, Robert, and Ulli Steltzer. (1991). The Black Canoe: Bill Reid and the Spirit of Haida Gwaii. Vancouver/Toronto: Douglas \& McIntyre.

Gandhl of the Qayahl Llaanas. (2001). Nine Visits to the Mythworld, trans. Robert Bringhurst. Vancouver/Toronto: Douglas \& McIntyre, and University of Nebraska.

\section{Secondary sources}

\section{PUBLISHED SOURCES}

Blodgett, E.D. (1983). "How Do You Say 'Gabrielle Roy'?" In Translation in Canadian Literature, ed. Camille La Bossière. University of Ottawa Press, $13-34$.

Elder, Jo-Anne. (2002). Editor's Note. Ellipse: Canadian Writing in Translation, 69, 6-10. (Fall 2002: Fred Cogswell, Friend of Poets. Fredericton.)

. (2003). "Bumps Along the Road." In Intercultural Journeys/Parcours interculturels. (Collected Papers: Comparative Canadian Literature Conferences, 
Université de Sherbrooke), eds. Natasha Dagenais and Joanna Daxell. Baldwin's Mills, QC: Les Éditions Topeda Hill, 255-264.

Sommer, Doris. (1999). Proceed With Caution, When Engaging Minority Writing in the Americas, Cambridge: Cambridge University Press.

Venuti, Lawrence. (1995). The Translator's Invisibility. London: Routledge.

UNPUBLISHED SOURCES

Elder, Jo-Anne. (2003). "Academics, Ambassadors and Artists: The Changing Role of the Literary Translator." (Unpublished paper presented to the Canadian Association of Translation Studies, Halifax, May, 2003.)

\section{INTERNET SOURCES}

Tayler, Anne, and Celi, Catarina. (1998). Working Draft, 1 February 1998, bibliography: Robert Bringhurst. www.umanitoba.ca/canlit/bibliographies/ robert_bringhurst.shtml (consulted November 22, 2005). 
This page intentionally left blank 


\section{"Long Time No See, Coolie" Passing as Chinese through Translation}

I n 1900, Ernest Bramah Smith published The Wallet of Kai Lung, purporting to be a collection of tales told by a Chinese storyteller, Kai Lung. Following its success, Smith published at least four additional anthologies sporadically over the next thirty years, and most of these works were reprinted one or more times up to the 1980s (see bibliography). Although it is nowhere explicitly stated, the stories purport to be "genuinely" Chinese. Such works form part of the intersection of two minor traditions in European literature, that of the Oriental tale and that of spurious translation (original works that are passed off as translations from foreign languages). If Smith could not read Chinese, why did he feel confident that he could transcreate "Chineseness" in his English works? What were the linguistic markers of this "Chineseness" in English, and how did they develop? If he is burlesquing or creating a pastiche, of what exactly is it a pastiche?

This question requires treatment from the point of view of the history of translation, the answer lies in the preceding century of Chinese- 
English translation practice. Beginning with Sir George Staunton, ${ }^{1}$ a style of writing was developed which was taken to be "Chinese" by the reading public. It is the style of these translations that Smith builds on to create his effects. Thus translation of Chinese works into English was responsible, to a great degree, in creating the notion of "Chineseness" in nineteenth- century England, which in turn is used by Smith. I will first outline the general characteristics used by Smith in The Wallet of Kai Lung, and then trace these back to various nineteenth-century translators. I will then use insights from queer theory in an attempt to understand that historical process in its contemporary context.

\section{Smith's translation: Speaking "Chinese" in English}

Spurning the type of pidgin English commonly ascribed to Chinese in the popular press, Smith depends mainly on vocabulary choice for his effect. First, it should be clear just from the title of the book that he uses "Chinese" names for all his characters, and indeed the title of each story contains the name of some "Chinese" person. Further, names consist of either two or three syllables, and in at least certain cases the surname could actually be a common Chinese one: Huang, Lin, or Chan. Thus his names are grammatically correct, or "paroles" in the "langue" 2 of Chinese nomenclature, since they conform to the rules for the formation and number of syllables of a person's names. This holds true for place names as well, he sets certain scenes in Peking and Canton, both well-known Chinese cities, while his imaginary places are grammatically correct. ${ }^{3}$ It is probably too obvious to belabour the fact that these Chinese names all derive from nineteenth-century translation practice of sinologists, who developed these transliteration conventions.

Smith also displays quite a bit of knowledge of Chinese history and culture in his work: there are the obligatory references to men wearing pigtails ("suspending the offender by the pigtail from a low tree" [11]), burning prayer paper ("making many vows concerning the amount of prayer-paper which he would assuredly burn" [7]), sitting for public exams ("presenting himself for the public examinations at Canton" [13]), 
and drinking of rice spirits ("certain ceremonies connected with rice spirit" [39]). Perhaps less well-known are the name and location of the Miao people ("My followers are mostly outlawed Miaotze, who have been driven from their own tribes in Yun Nan for man-eating and disregarding the sacred laws of hospitality." [11]), familiarity with the monetary system ("six or eight cash" [11 $]_{i}$ "taking from a concealed spot in his garments a few taels, he placed them before the secretary" [16]), the Four Books and Five Classics ("how could it be that one whose chief delight lies in the passive contemplation of the Four Books and the Five Classics, should be selected by destiny to fill a position calling for great personal courage and an aggressive nature?" [23]), and divination ("he consulted the Sacred Flat and Rounded Sticks, and learning that the following day would be propitious for the journey, he arranged to set out in accordance with the omen." [48]). These details provide local color which, if familiar to the reader, confirms that the story takes place in China and, if not, provides exotic details of Chinese life. Again, all of these "facts" can be found in earlier translations.

More interesting is his use of certain linguistic practices which, although not ungrammatical, are statistically unusual in English. These can be grouped into four main areas:

1. Maxims and proverbs (on average approximately 1 per page)

He is a wise and enlightened suppliant who seeks to discover an honourable Mandarin, but he is a fool who cries out, "I have found one." (20)

\section{Excessively polite language}

"It is a valuable privilege to have so intelligent a person as the illustrious Ling occupying this position," remarked the Mandarin, as he returned the papers; "and not less so on account of the one who preceded him proving himself to be a person of feeble attainments and an unendurable deficiency of resource."

"To one with the all-knowing Li Keen's mental acquisitions, such a person must indeed have become excessively offensive," replied Ling 
delicately; "for, as it is truly said, 'Although there exist many thousand subjects for elegant conversation, there are persons who cannot meet a cripple without talking about feet."' (28)

\section{Figurative speech}

- writing-leaves (paper) (19)

- powerful malignity (hatred) (21)

- deep feeling of no enthusiasm (29)

\section{Adverbial and adjectival modifiers}

- extortionate and many-handed persons at Peking (17)

- $[\mathrm{H}] \mathrm{e}$ beheld a young and elegant maiden of incomparable beauty being carried away by two persons of most repulsive and undignified appearance whose dress and manner clearly betrayed them to be rebels of the lowest and worst-paid type. (24)

Examples could be multiplied indefinitely; almost no sentence is free from one of these four traits, and many contain two or even three. On the linguistic level, then, these four characteristics are what mark the text as being different from standard English, they must then be markers of "Chineseness." How and why did these characteristics come to be viewed as such?

\section{Nineteenth-century translations as precursors}

Compare these sentences by six early translators of Chinese published between 1810 and 1843:

- The bow will soon be unstrung, and the war at an end. (Weston 1810, 21)

- $[\mathrm{W}]$ ing to the frequent repetition of the General's name, by his victorious soldiers, in uninterrupted songs of victory on every side; on the land, in the midst of the waters, and on the banks of the river, full without overflowing. (Weston 1810, 38)

- I, even I their Emperor, have never remitted my anxiety, or ceased to doubt, or reposed under the clear sky of noon-day for the shortest 
moment; but have shared the taunts, the inward sadness, the unwilling reluctance to the end, equally with my troops. (Weston 1810, 53)

- My family was poor, and I was myself of a weak and sickly constitution. I never was able to attain to any very considerable proficiency . . . the emperor was graciously moved to promote me in consequence to that superior office (spoken by a high-ranking official). (Staunton 1821, 5)

- $[\mathrm{O}]$ ur tongue is dry and our lips parched with admonishing and reprehending him. (Staunton 1821, 290)

- If he happens not to be desirous to see you, and consequently sends no messengers to invite you to a conference, it is very immaterial. (Staunton 1821, 12)

- [A man who has been arrested] is one of the low and ignorant peasantry $_{i}$ - wherefore his audacity in presuming to rush into the Imperial hall, in order to state these weak and unsubstantiated assertions, is highly reprehensible and illegal. (Staunton 1821, 310)

- $[E]$ ighteen years have elapsed, since, possessed of but inferior virtue, I looked up and received with profound veneration the throne from my Imperial Father, after which I dared not to resign myself to ease or inattention to the affairs of Government. (Morrison 1815,4)

- $[R]$ ebellion rose under my own arm [with a footnote: "Under my own armpit, meaning his own Family"]. (Morrison 1815, 5)

- $[\mathrm{H}]$ is infant Family [with a footnote: "The whole nation."]. (Morrison $1815,29)$

- They mutually diverged from each other, as the Heavens from the Abyss. How dissimilar branches spring from the same stem, will be perceived. (Davis 1815, 6)

- This may be called "taking flesh to feed an ulcer." (Davis 1815, 13)

- $[\mathrm{H}] \mathrm{e}$ retreated from the crowd, retired from noise, divided himself from men, and shut out example (with a note: "This may appear like tautology, but it [is] a literal translation, of the original. A great deal of such repetition prevails in Chinese writing.") (Davis 1815, 18)

- [L]onesome ghost. (Davis 1815, 28)

- Peking the 21st year of Kea-king, 5 Moon, 27 day, (June 1816). 
- Tsing-chang, of the Imperial blood, and general, in command of the city Shing, together with Yung Tsoo, holding the office of She-lang, kneel down and report. - Profoundly honouring the Imperial mandate to assemble and rigorously investigate, and determine on punishments proper to be inflicted, we respectfully present this document, praying that it may please His Majesty to examine it.

- We ... [footnote: "We Noo-tsaie, i.e., slaves—all persons of the Tartar race in China, even the bighest, are obliged to use this degrading epithet when speaking of themselves. Those of the Chinese race when speaking of themselves use chin, which is a more respectable epithet." (Anonymous 1817, 18)]

- [T] he golden mouth [of the emperor]. (Shen 1843, 13)

- [A]greed together as glue with varnish. (Shen 1843,14)

- The man who stedfastly pursues

The path of bonour bright

Is not afraid, though knocking loud

Rouse bim at dark midnight (Shen 1843, 20)

- We are not worthy to occupy our important offices, and we render our titles but empty designations; we are full of shame at not having heretofore assisted and corrected your majesty. . . (Shen 1843, 24)

Although the language of these texts taken as a whole is not as exaggerated as Ernest Bramah Smith's, all of the translations show a tendency toward the type of language he parodies. Certain types of texts tend to contain more of one form or another. The translations of imperial edicts or memorials presented to the emperor tend to have a high concentration of polite and self-abasing language, while containing few moral maxims, and Staunton's translation contains no maxims at all. David's San-yu-low, on the other hand, contains a fairly large number of sayings, proverbs, or quotations from the classics to be applied to daily life, and even contains one on the title page, but relatively little polite speech. And Tkin Shen's translation contains a large number of figurative expressions but not as much exaggerated use of adjectival and adverbial modifiers. As for moral maxims, more than one translation in the nineteenth century was of moral maxims alone, or contained a group of 
moral maxims as an appendix to another work (Milne 1817, Davis 1822a and 1822b, Scarborough 1875).

These and later translations of Chinese texts, then, established in the mind of British readers certain fixed characteristics of the Chinese language and the way in which the Chinese expressed themselves. This "Chineseness" included the frequent use of moral maxims, often derived from the classics; a tendency to hyperbolic flights of polite speech; the frequent use of unusual metaphors; and finally a tendency to use modifying phrases and repetitive structures.

Metacommentary in the translations and pseudo-translations

More than this, however, the translations also often provided direct or indirect commentary by the translators which shaped and guided the readers' understanding of the nature of Chineseness as being inferior. After translating an edict in which the emperor lashes out against abuses committed by his army while putting down a rebellion (they had kidnapped children to sell as slaves), Morrison adds a commentary: "The tenor of the Imperial Edicts, unquestionably shews [sic] the reigning Emperor to be a humane man. This is also the character which his People give him, but they complain, that be keeps in the Government a bad set" (Morrison 1815, 38; emphasis added). The translation shows the emperor to be a good man, but the commentary warns the reader that this one good man is surrounded by many evil ones. Slightly earlier, Morrison also warns the reader of the profound discrepancy between what the Chinese say and how they act: "there is no nation in the world in which professions and practice are more at variance than in China" (Morrison $1815,35)$. Both of these examples exhibit what was perceived to be an ongoing condition of sinological translation in the nineteenth century: that there was a split between what texts say in Chinese and the reality in China. It then falls to the translator to reveal to the British reader the "truth" behind the fictive text.

This practice of metacommentary accompanying the translation, and the ideas expressed in it, is also used by Smith in his Kai Lung stories. 
Unlike the translators, however, who felt the need to make comments outside the translation, Smith makes the text itself reflexively judgmental by creating an ironic distance between the narrator, the characters, and the British reader. This irony is produced mainly by the exaggerated use of the four rhetorical markers I discussed above.

On the very first page Smith gives us certain indirect and direct hints that the surface of the text we are reading glosses over a very different reality. The story begins with Kai Lung journeying through a forest famous for brigands on his way to the town of Knei Yang, having scoffed at the danger:

Nevertheless, when within the gloomy aisles, Kai Lung more than once wished himself back at the village, or safely behind the MUD WALLS of Knei Yang; and, making many vows concerning the amount of prayer-paper which he would assuredly burn when he was actually through the gates, he stepped out more quickly, until suddenly, at a turn in the glade, he stopped altogether, while the WATCHFUL EXPRESSION INTO WHICH HE HAD UNGUARDEDLY DROPPED AT ONCE CHANGED INTO A MASK OF IMPASSIVENESS AND EXTREME UNCONCERN. From behind the next tree projected a long straight rod, not unlike a slender bamboo at the distance, but, to Kai Lung's all-seeing eye, in reality the barrel of a matchlock, which would come into line with his breast if he took another step. Being a prudent man, MORE ACCUSTOMED TO GUILE AND SUBSERVIENCE TO DESTINY THAN TO FORCE, he therefore waited, spreading out his hands in proof of his peaceful acquiescence, and smiling cheerfully until it should please the owner of the weapon to step forth. $(7$; emphasis added)

The walls for such a town, in fact, would be beaten or packed earth; but the use of "mud" suggests something much less solid or reliable. What Kai Lung thinks of as safe, then, is not the British reader's idea of safety ${ }_{i}$ Chinese fortified towns are defended by nothing but mud. The narrator also tells us that Kai Lung is very concerned to control the 
expression of his face: being watchful would perhaps be the attitude of someone with something to hide, or suspicious of others; instead, Kai Lung adopts a mask for the benefit of the man with the gun, because he is going to use guile in dealing with him. Finally, the narrator's definition of a prudent man, "more accustomed to guile and subservience to destiny than to force," reinforces the idea that Kai Lung and, indeed, all "prudent men" of China have very different ideas of how to act than the British: with guile and subservience to destiny. That notion of destiny echoes Kai Lung's vow to burn prayer-paper; ${ }_{i}$ he is, in a word, superstitious. Note also the frequent use of modifiers and metaphors; when speaking of the vows, "many" "assuredly" and "actually" all serve to make him sound extremely superstitious.

Kai Lung and Lin Yi then begin to talk and, as expected given that Kai Lung is using guile, Smith puts extremely polite speeches into their mouths. Here is one short exchange between them:

[Lin Yi: ] ". . . Doubtless, at this moment many Mandarins of the highest degree are anxiously awaiting your arrival at Knei Yang, perhaps passing the time by outdoing one another in protesting the number of taels each would give rather than permit you to be tormented by fire-brands, or even to lose a single ear." "Alas!" replied Kai Lung, "never was there a truer proverb than that which says, 'It is a mark of insincerity of purpose to spend one's time in looking for the sacred Emperor in the low-class tea-shops... . . Indeed, the person who is now before you is none other than the outcast Kai Lung, the story-teller, one of degraded habits and no very distinguished or reputable ancestors. His friends are few, and mostly of the criminal class. ..." (10)

Again, note the use of modifiers and of proverbs.

Thus all of the techniques I have discussed become associated with falsehood in Smith's text. Within the tale which Kai Lung tells to the brigands in the hope of being set free, this association is maintained. His hero Ling, a good man who journeys to Canton to take the exams, 
is appointed as a military commander in a rebellious province and succeeds in putting down the rebels but almost loses his life in the process. He is portrayed as being innocent at the beginning and therefore capable of understanding neither the polite speech nor the stratagems of others. Thus when the doorkeeper of the local mandarin tells him in a convoluted way that his master cannot be disturbed, Ling takes this lie at face value and turns to leave, when in fact in the "code" of polite speech it is an indirect way of asking for a bribe. Realizing that Ling is clueless, the gatekeeper fashions a complicated story that ends by asking Ling to lend his (expensive) ring to the gatekeeper "as a very powerful charm against evil, misunderstandings, and extortion" while he goes in to announce Ling (14). Ling of course never gets the ring back. This process is repeated twice more by two higher-level flunkies (Ling loses a rich cloak and several taels of silver), and then the mandarin extorts a substantial sum from Ling, saying that it is demanded by the "extortionate and many-handed persons at Peking who have control of the examination rites and customs" (17). Ling has a similar encounter with a man who offers to sit in for him at the examinations for a fee (19-20). Ling gradually comes to understand and use this language to his own advantage, although it is not always clear whether he penetrates the ruses of others and matches guile with guile, or whether he believes what they say and replies innocently with the proper response. Li Keen, the mandarin in charge of military affairs in the area when he arrives at his post, tells him of how his predecessor was demoted and fined heavily after refusing to pay Li Keen off: "It was a just and enlightened conclusion of the affair,' said Ling, in spite of a deep feeling of no enthusiasm, 'and one which surprisingly bore out your own prophecy in the matter'" (29). Here we see Ling understanding the indirect threat to himself, being unhappy about it, but masking that unhappiness with a polite expression, which contains the tiny barb "surprisingly."

On more than one occasion Ling is portrayed as cutting through the web of language to the heart of the matter, and such actions by him are always portrayed in a positive light: "In spite of his very inadequate attainments regarding words of order, the Commander made it understood 
by means of an exceedingly short sentence that he was desirous of the men returning without delay" (33). Amusingly, we are told about this exceedingly short sentence by an extremely long one. At such moments, the British reader identifies with Ling through the web of verbiage spun by Kai Lung.

Besides their association with a propensity to falsehood, guile, superstition, and bribery (of which there are many other examples in the text), these techniques are also used to show the British reader that the Chinese are sticklers for ceremony $(26-7)$, they take pride in outward signs of office (51), their army is ineffective and cowardly $(28,32-43$, $36-8)$, and they rely on received wisdom rather than thinking for themselves $(36-7,39)$. Moreover, the ironic distance Smith establishes ensures that the reader sees that these are all undesirable or ineffective. In the midst of a battle, Ling finds himself surrounded by the enemy and begins to quote Confucius; he is assaulted and left for dead (39). Faced with force, what is the use of rote learning?

All of these undesirable traits may be found in earlier nineteenth-century translations. In regard to being sticklers for ceremony, Staunton translates an imperial edict regarding the exact distance on foot the emperor is to walk during the funeral procession for his father (Staunton 1821, 262-3); this compares to Smith's long description of how a mandarin refuses to receive Ling because he has not arrived at the gates in a sedan chair, ending with: "the refined observances laid down by the wise and exalted Board of Rites and Ceremonies have a marked and irreproachable significance when the country is in a state of disorder, the town surrounded by rebels, and every breathing-space of time of more than ordinary value" (27). Regarding outward signs of office, again Staunton translates a passage where an official is "to hold his situation, and wear an honorary button, though nominally to be degraded and deprived of the insignia of the peacock's feather" for ineptitude in conducting a war (Staunton 1821, 265) ; compare this to Smith's "It has been suggested to the mandarin Li Keen that the bestowal of the Crystal Button would only be a fit and graceful reward for his indefatigable efforts to uphold the dignity of the sublime Emperor" (51). Too 
long to quote here, Staunton translates several edicts and memorials from the Peking Gazette which show that the campaign against the Miaozu was protracted and ill-planned, and resulted in great destruction and loss of life due partly to incompetence and lack of cooperation between officers (Staunton 1821, 264-6; 267-8; 268-71; 271-5; 277-9; 279-85; $286-91 ; 299-302)$; passages in Smith's story describing the behaviour of Li Keen, soldiers, and the Chief of Bowmen all tend to the same end (30-39, 46-7, 50-2).

Smith is thus able to pass as Chinese for British readers, not only because he imitates the language used by nineteenth-century translators, but also because he repeats and reinforces the stereotypical notions of what it means to be Chinese. These two phenomena are bound together, with the means of expression indissolubly linked to the content. It is because the Chinese possess these qualities that they speak in this manner: polite speech is a mask for ruse, and hyperbolic language covers up incompetence.

\section{Translation as passing}

Having established a historical link between nineteenth-century translation practice and Smith's pseudo-translation at the dawn of the twentieth century, I would like to draw some parallels between what both Smith and the earlier translators were doing and other contemporary practices of role-playing or performance which centre on the act of passing. The concept of passing, as it has been developed in AfricanAmerican studies and queer theory, usually involves members of a minority/oppressed group in society learning to mimic the looks, speech and behaviour of the dominant majority. Smith, on the other hand, is disguising himself as a member of a foreign and, for early-twentieth-century Britain, generally despised group, an action usually described by other terms (slumming, minstrel show), and related to another form of role-playing (cross-dressing). Slumming involves a member of the dominant group traveling (often in disguise) into the space of the lower classes (Hitchcock 2001, 170). The purpose of slum- 
ming varies from philanthropy to curiosity, but the product is often the same: a text written by the slummer describing the lower classes. A classic example is Richard Burton's memoirs of his pilgrimage to Mecca (Burton 1855). One important function of such literature is to assert the difference between classes (or ethnic groups/races) (Hitchcock 2001, 183). Those differences often involve language (Hitchcock 2001, 178); the slummer's desire to reproduce an authentic cockney, or the language of dock workers, may lead to a concentration and exaggeration of certain linguistic features for effect, as occurs both in the nineteenthcentury translations and in Smith's text.

Another related activity is the American tradition of the minstrel show (or black-face), where white men would dress themselves up as African-Americans, black their faces, exaggerate certain features, (wide eyes, thick lips), and then perform on stage an exaggerated caricature. Along with the associated activities of burlesque and pastiche, minstrel shows again functioned as a delineation of boundaries by crossing those bounds, and language was always an important element (Itzkovitz 2001, 39-47, 51-2). Thomas Holt makes several important points in an article from 1995:

Racial selves - black as well as white - were made in the social environments of theatrical and street performances. . . . aspects of black life — even black creativity — were appropriated and used by whites to negotiate problems posed by the larger society. Thus a racist discourse and performance became media for fashioning as well as expressing white, expecially white male, identity.... What was America? Who was an American? Who was "white"? ... . In the minstrel theater, such issues were deflected or settled symbolically; there, perhaps, white men at least reassured themselves who they were not - not black, not slave. Minstrelsy soothed white anxieties, however, at the cost of reinforcing black stereotypes and institutionalizing racist ideas and images for generations to come. (Holt 1995, 15-16) 
Much of what he says about minstrel shows might profitably be applied both to the early nineteenth-century translations quoted above and to the character of Kai Lung, that whimsical man from a never-never land whom the British can laugh at safely. Reading such texts, the British can point and say, "we are not Chinese."

Cross-dressing, as Judith Butler pointed out many years ago, may show the constructed nature of gender roles (Butler 1990, 137-8). That such roles are constructed, however, does not mean that they are any less real or powerful, and recently Sharon Ullman has argued that male impersonators in the late nineteenth/early twentieth century were used by men "as a powerful tool for containing the subversive quality of feminist political critiques" (Ullman 2001, 188). The activity may in fact serve to sharpen and refine the differences between gender roles. Other critics have argued that, in a similar fashion, racial passing narratives are inevitably complicit with racial ideologies (Smith 1994, 43-44; Harper 1996, 126): it is only when you can imagine "white," "black," and "Chinese" as stable categories that you can mimic them and thus pass. Again, it seems clear that all of the texts I have examined are also interested in maintaining the separateness and stability of racial categories.

Unlike racial passing, the success of cross-dressing often relies on the audience being able to discern the disguise. This is also true of the minstrel show, where the disguise is meant to be penetrated; in both cases, being black, being female or, in the case of Smith, being Chinese, is a disguise that functions through its being seen through. People go to the show knowing that they are going to see a disguise.

Finally, another contemporary British concern with borders and definitions of self and other involved the Anglican and the Catholic Church. Here again, to simplify other people's arguments, the language of the Catholic Church was seen as duplicitous, effeminate, and seductive (O'Malley 2001, 239-41). In an attack on a former Anglican turned Roman Catholic, Charles Kingsley complained: "The whole sermon is written in so tentative a style, that it would be rash and wrong to say that Dr. Newman intends to convey any lesson by it, save that the discovery of truth is an impossibility." ${ }^{4}$ This description could 
almost be used to characterize the speech of Chinese in Smith's text. Such a comparison may not be as far-fetched as it seems at first sight if we remember that one of the defining elements of British sinology was that it was different from French (Catholic) sinology, and that parallels between Buddhism and Catholicism were often drawn in the interest of debasing both. ${ }^{5}$

\section{Conclusion}

First and foremost, Smith's text must be understood in the context of the history of nineteenth-century translation from Chinese into English. It is that history which establishes and defines "Chineseness" for the British. Smith exploits both the more exaggerated linguistic markers of this discourse and the underlying fears that it plays upon. It should also be remembered in this context that the term "Yellow Peril" was coined in the 1890s. British anxieties about this yellow peril are negotiated and diffused through Smith's passing as a Chinese, who reveals the Chinese to be paper tigers. Second, both Smith's fiction and the earlier translations need to be understood in the larger historical context of the nineteenth century, including a nexus of inter-related practices related to passing; these practices all reflect anxieties relating to borders between the self and the other, and they all involve the use and control of language as a marker of authentic and inauthentic discourse. Seen in this light, Smith's decision to use certain types of exaggerated language to establish the "Chineseness" of his discourse is completely understandable.

Finally, this connection opens up two avenues for further research. First, the history of sinological translation needs to be carefully reexamined in terms of passing. Once the connection is made, there are too many similarities for us to dismiss them as chance or arbitrary. Such a re-examination of the history of sinological translation would have to go further back in time to the early missionary translators and to the vogue for the oriental tale in the eighteenth century. Second, the question of when and under what circumstances translation can be 
understood as a form of passing deserves more thought. Is translation always a type of passing? Can all translation activities be mapped onto the various models of passing (passing, blackface, cross-dressing, slumming)? Certainly if translation is seen as a form of performance, the potential is always there. Whether or not this is a fruitful avenue for understanding other translation activities will depend on further careful case studies.

\author{
JAMES ST. ANDRÉ \\ University of Manchester \\ (United Kingdom)
}

\title{
Notes
}

1. While still a child, Sir George Thomas Staunton (1781-1859) travelled to China along with his father as part of the Macartney embassy of 1793. His father hired a Chinese tutor for him, and later he returned to Canton to work for the East India Company. See Staunton (1810, 1821, and 1822) for the titles of works he translated from Chinese.

2. The distinction between langue and parole is taken from Saussure 1916.

3. A small number of names are not phonetically correct according to any dialect of Chinese I am aware of: Fel and Knei are the two examples I found in this book. Their ungrammatical nature, however, would not be obvious to anyone without a knowledge of Chinese.

4. Kingsley $(1968,334)$, as quoted in O'Malley $(2001,143)$.

5. For a recent work discussing the link between Catholicism and decadence, see Hanson (1997). On the Catholic-Protestant rivalry in translation from Chinese, see St. André (2003).

\section{References \\ Primary sources}

\section{A. NINETEENTH-CENTURY TRANSLATIONS}

Anonymous. (1817). The Indo-Chinese Gleaner: Containing miscellaneous communications on the literature, bistory, philosophy, mythology, \&c. of the Indo-Chinese nations, drawn chiefly from the native languages, 1:1 (May), 18. [probably done by William Milne, the editor]. 
Davis, Sir John Francis. (1815). "San-yu-lou; Or the Three Dedicated Chambers." In Translations from the Original Chinese: With Notes. Canton, China: Printed by order of the Select Committee. - (1822a). Chinese Moral Maxims, with a free and verbal translation, affording examples of the grammatial structure of the language. London: John Murray, 1822.

(1822b). Chinese Novels, Translated from the Originals, to which are added Proverbs and Moral Maxims, collected from their classical books and other sources. The whole prefaced by Observations on the language and literature of China. London: John Murray.

Milne, William. (1817). The Sacred Edict: Containing Sixteen Maxims of the Emperor Kang-be. Amplified by bis son, the Emperor Yoong-ching together with a paraphrase on the whole, by a mandarin. Translated from the Chinese original, and illustrated with notes. London: Black, Kingsbury, Parbury and Allen.

Morrison, Robert. (1815). Miscellaneous edicts extracted from the Peking Gazette in Translations from the Original Chinese: with Notes. Canton, China: Printed by order of the Select Committee.

Scarborough, William. (1875). A Collection of Chinese Proverbs. Translated and arranged by William Scarborough...with an introduction, notes and copious index. Shanghai: American Presbyterian Mission Press.

Shen, Tkin. (1843). The Rambles of the Emperor Ching Tib in Këang Nan. A Chinese Tale. Translated by Tkin Shen, with a preface by James Legge. London: Longman, Brown, Green, and Longmans.

Staunton, Sir George Thomas. (1810). Ta Tsing Leu Lee, being the fundamental laws, and a selection from the supplementary statutes, of the Penal code of China, originally printed and published in Pekin, in various successive editions, under the sanction, and by the authority, of the several emperors of the Ta Tsing, or present dynasty. London: Cadell and Davies.

. (1821). Narrative of the Chinese Embassy to the Khan of the Tourgouth Tartars: in the years 1712, 13, 14, and 15. By the Chinese Ambassador. London: John Murray.

(1822). Miscellaneous Notices Relating to China and Our Commercial Intercourse with that Country: Including a Few Translations from the Chinese Language. 2nd edition, enlarged in 1822, and accompanied, in 1850, by introductory observations on the events which bave affected our Chinese commerce during that interval. London: John Murray, 1822-1850.

Weston, Stephen. (1810). The Conquest of the Miao-tse; an Imperial Poem, by Kien-Lung, entitled, A Choral Song of Harmony for the first Part of the Spring. [London]: Baldwins. 


\section{B. WORKS OF ERNEST BRAMAH SMITH}

(originally published under the pseudonym Ernest Bramah)

(1900). The Wallet of Kai Lung. London: Grant Richards. Republished/reprinted in 1911, 1917, 1923 (4 editions in 2 countries), 1926, 1929, 1936, 1954, 1979, and 1986.

(1905). The Mirror of Kong Ho. London: Chapman and Hall. Reprinted in 1929 and 1930.

(1922). Kai Lung's Golden Hours. London: Grant Richards Ltd. Republished/ reprinted in 1924, 1938, 1939, and 1985.

(1928). Kai Lung Unrolls His Mat. Garden City, NY: Doubleday, Doran. Republished / reprinted in 1935, 1937, and 1974.

(1932). The Moon of Much Gladness. London: Cassell and Company.

(1940). Kai Lung beneath the Mulberry-tree. London: Richards Press. Reprinted in 1978.

(1936). The Kai Lung Omnibus. London: Philip Allan, 1936. Republished in 1963. Contains The Wallet of Kai Lung, Kai Lung's Golden Hours, and Kai Lung Unrolls His Mat.

\section{Secondary sources}

Burton, Sir Richard Francis. (1855). Personal Narrative of a Pilgrimage to Al-Madinab and Meccab. London: Longman, Brown, Green, and Longmans.

Butler, Judith. (1990). Gender Trouble: Feminism and the Subversion of Identity. New York: Routledge.

Saussure, Ferdinand de. (1916). Cours de linguistique générale. Published by Charles Bally and Albert Sechehaye in collaboration with Albert Reidlinger. Paris: Payot.

Hanson, Ellis. (1997). Decadence and Catholicism. Cambridge, MA: Harvard University Press.

Harper, Philip Brian. (1996). Are We Not Men? Masculine Anxiety and the Problem of African-American Identity. Oxford: Oxford University Press.

Hitchcock, Peter. (2001). "Slumming." In Passing: Identity and Interpretation in Sexuality, Race, and Religion, ed. Maria Carla Sanchez and Linda Schlossberg. New York: New York University Press, 160-186.

Holt, Thomas C. (1995). "Marking: Race, Race-making, and the Writing of History." The American Historical Review, 100:1 (Feb.), 1-20.

Itzkovitz, David. (2001). "Passing Like Me: Jewish Chameleonism and the Politics of Race." In Passing: Identity and Interpretation in Sexuality, Race, and Religion, ed. Maria Carla Sanchez and Linda Schlossberg. New York: New York University Press, 38-63. 
Kingsley, Charles. (1968). "What, Then, Does Dr. Newman Mean?" (first published 1845). Reprinted in Newman, Apologia pro vita sua, ed. David J. DeLaura. New York: W. W. Norton and Company, 310-340.

O'Malley, Patrick R. (2001). "The Church's Closet': Confessionals, Victorian Catholicism, and the Crisis of Identification." In Passing: Identity and Interpretation in Sexuality, Race, and Religion, ed. Maria Carla Sanchez and Linda Schlossberg. New York: New York University Press, 228-259.

St. André, James. (2003). "Retranslation as Argument: Canon Formation, Professionalization, and Rivalry in Nineteenth Century Sinological Translation." Cadernos de tradução, 11:1, 59-93.

Smith, Valerie. (1994). "Reading the Intersection of Race and Gender in Narratives of Passing." Diacritics, 24:2-3 (Summer-Fall), 43-57.

Ullman, Sharon. (2001). "The 'Self-made Man': Male Impersonation and the New Woman." In Passing: Identity and Interpretation in Sexuality, Race, and Religion, ed. Maria Carla Sanchez and Linda Schlossberg. New York: New York University Press, 187-207. 
This page intentionally left blank 


\section{The Imperial College of Santa Cruz de Tlatelolco}

The First School of Translators and Interpreters in Sixteentb-Century Spanish America ${ }^{1}$

he foundation and scope of teaching centres in sixteenth century
Nueva España, in particular the Imperial College of Santa Cruz de Tlatelolco and the one in Cuauhtitlán, as well as the role they played, need to be re-examined from another standpoint in the history of translation.

Santa Cruz de Tlatelolco, the first major school of interpreters and translators in the New World, was founded around 1573 and reformed about forty years later. Its role is in many ways reminiscent of the one played in Europe by the famous Toledo School founded by Bishop Ramon in Alfonso el Sabio's time. Most of the evidence referring to Santa Cruz de Tlatelolco emphasizes that its foundation, as well as that of similar institutions, was influenced by three powers: the Crown, His Holiness the Pope, and the absolute and all-embracing Order of Saint Francis. Its foundation facilitated its performance as a training centre for the future native Mexican ruling elite and supplanted - rather than balanced - the role that the calmecac or telpocbcalli played in the general 
education of Nahuas of noble birth, especially in religious matters. The calmecac or telpocbcalli operated as special schools where, among other subjects, the interpreting art of pre-phonetics and the hieroglyphic writing of pictograph codes were taught. The Mexican scribes trained there were responsible for transcribing on amate or vegetable paper the magical or religious thinking as well as the habits and customs of the people.

Several analysts have surmised that, for the priests, it was a matter not only of guiding the training of the future ruling class at Santa Cruz de Tlatelolco, but also of laying the foundation for a regular Mexican clergy. The idea of educating the ruling class there from early childhood according to the principles and commandments of the Catholic Church as well as the canons of European culture was obviously a main tenet. Probably some subjects were included at a senior level for the purpose of creating an elite group of students from which the first Mexican Catholic priests would be selected, although this was not the main objective.

Other researchers have suggested a third hypothesis: that the top priority of these centres was the training of native linguists with the ability to perform a sort of spiritual intermingling to reconcile cultural spheres as well as challenge Renaissance humanism and meso-American wisdom in several respects:

- By eradicating their idolatries. To this end, the priests' bilingual (Náhuatl and Castillan) re-writing and/or re-wording of their ancestors' memories written in original text either vanished without a trace or were engulfed in flames before their very eyes, causing them "incidentally" to retrace the path to the sense of their own beliefs for themselves.

- By preparing them to work as translators and interpreters in order to support the pastoral priests' attempt to indoctrinate by linguistically backing their advocacy of the Christian religion.

- By teaching them to undertake translation and interpretation of the Christian religion's sacred texts directly into native tongues, mainly Náhuatl. 
Our work here aims to support the third hypothesis as being of undeniable significance for the history of translation and interpretation in America.

\section{Location and origin}

Fray Bernardino de Sahagún, the pioneer ethnographer of sixteenthcentury Aztec Mexico, obsessed with the idea of exterminating any idolatrous practices by the natives, was involved in renaming places using historical references. Under a spring in Xochimilco, he found a stone idol to which the natives offered copal. Aware of the significance that the natives accorded the water and mountains, he took away the idol and replaced it with a cross, christening the place Santa Cruz, as it was called from then on.

\section{Ideological background}

Invaders did not respect the indigenous culture. With the Conquest, the calmecac and telpochcalli disappeared, and with them, traces of their teachings were lost. Because the temples and monuments, codes and books were completely destroyed, when it became necessary to obtain accurate and substantive information about the past, recourse had to be made to the remaining evidence: the essential facts and history were reflected through the glyphs.

When speaking about the codices in terms of their significance in cultural history as an advanced system relying on material support to represent human thinking, one tends to mention only those codices that replaced the papyrus rolls of the Greeks and Romans in the second and third centuries AD. Fernando R. Lafuente, for instance, referring to the appearance of the codex in Europe only, without mentioning its presence in the former indigenous cultures of Middle America, pointed out how its emergence allowed new gestures, like leafing through a work or writing and reading at the same time, and how important the experience was for authors or scribes in organizing 
the transmission of thoughts in a new way, in books, parts, or chapters of a single discourse. ${ }^{2}$

Of course, this suppression of evidence was in line with the aims of the Christianization process, but later it became imperative to carry out pastoral work with a functional approach, focused on a native, concrete and supposedly omnipresent audience. With the heir to this knowledge and the repository of the same memory destroyed, it was obvious that the possibility of decoding that valuable data was irretrievably lost. Besides, the priests were obliged to resort to oral sources, taking advantage of the fact that most legends had been transmitted from one generation to another by oral tradition. The Mexicans used to hold informal meetings where the elderly members of the communities recounted their memories. And that is why the teachers in Santa Cruz, when looking for information, and interested in investigating the primary sources, were compelled to turn to the collective memory of those wise, elderly men. The latter had etched on their memories what the codices contained, not only about the origins of the religious pantheon and its presence in the imaginations of the people or about how the individuals managed to cook or process pulque (a Mexican drink), but also about the background of the moral, poetic and religious discourses which allowed them to reconstruct the history or at least the anecdotal discourse. The history was therefore reconstructed in two alternate voices influenced by the respective idiolects of narrators and mediators.

In Chapter XI, Book VI of Historia General de las cosas de la Nueva España, Fray Bernardino de Sahagún, the main author, describes and comments on the indigenous beliefs about rhetoric, philosophy and theology before the arrival of the Conquerors in Nueva España. The famous Franciscan warned against the calmecac, calling them satanic inventions and a source of idolatry. The implicit criticism contained in the seventh reprimand of the 1486 Manuscript $^{3}$ did not escape Georges Baudot: ${ }^{4}$

Here starts the seventh reprimand with which our Mother, the Holy Roman Church, admonished the people here, in Nueva 
España, with regard to the rules they applied in the old days when they engaged their children to be accepted to the calmecac or telpochcalli... . That's why you must beware and be informed, so I want to relate to you everything I know about the things that happened there once they were admitted to the calmecac or to the telpochcalli. Because the elders told me everything they have seen there once they have been christened, because they have been marked in, and because they have lived in, when they have approached Our Lord God, and they have related to me everything that I'm relating to you now, warning you about the common practices in the calmecac or telpochcalli. [our translation $]^{5}$

\section{Selection of students}

Having analyzed the political orientation of education allowed by the priests in those major schools in Mexico, we must note the following:

- The first feature that is patently obvious is the essentially selective and class-conscious nature of those centres.

- "Since the children of the Caciques, the future ruling class of Indians, were educated from childhood in the principles of our Catholic faith, our Order has founded colleges" [our translation]. This is clearly stated in Law XI of the Compilation of Indian Laws (23rd ed., Book I).

According to the Charter of the Imperial College of Santa Cruz, an essential requirement for acceptance as a student was to be: "an Indian born of a legitimate marriage, from Caciques or noble birth and not of 'macegual', despicable or blemished origin, or marked because of their own vulgar behaviour or that of their parents" [our translation]. ${ }^{6}$

From the very beginning, origin and lineage were binding prerequisites to being selected to receive this kind of education in the Spanish colonies. Hernan Cortez chose Indians, neither light-heartedly nor fortuitously, to take with him to Spain. The Franciscan missionaries learned 
their first words in Náhuatl from those selected Indians when they made the trip back to the New World together one year later. Francisco del Paso y Troncoso recovered the complete list of native travelers with the help of historian Chimalpahin-Cuauhtlehuanitzin, who fortunately made a note in a copy of the first edition, Chapter 62, Volume II of the Historia de la Conquista de Méjico by López de Gómura. ${ }^{7}$

The selective and discriminatory approach that characterizes the requirements for being entitled to an education in Latin America, and therefore for having access to general educational institutions and the teaching of the catechism, which surprisingly applied to an increasing number of students, ${ }^{8}$ would generate a problem of reversal that five centuries later is not as yet resolved in favour of the huge population descended from the Indians on this continent.

\section{Problems encountered and teaching orientation}

The topics that made up the Tlatelolco curricula are known, as are the results achieved by an outstanding group of trilingual residents headed by Alonso Vegerano of Cuauhtitlán and Antonio Valeriano of Azcapotzalco under the tutelage of Bernardino de Sahagún and his coworkers, mainly Fray Arnaldo Bassacio and Fray Andrés de Olmos.

It was common knowledge that divergent views were expressed concerning the policies applied in these colleges. Dissent from the mouths of distinguished clergy members was voiced by Fray Toribio de Paredes or Benavente, better known as Motolínea. There was a great deal of argument with Motolínea about the treatment of the Indians by the priests in Santa Cruz concerning idolatry, the teaching of grammar and, in general, the way that Sahagún conceived and carried out his pastoral mission. We must add that the few Santa Cruz teachers/interpreters/ translators were forced to improvise a good deal and overcome many technical difficulties since they did not have even lexical guides or manuals except those that they developed themselves with determination, inventiveness, and individual talent. ${ }^{9}$ While trying to learn a foreign tongue, they taught Latin, grammar, arts, basic theology, and music. 
Mendieta and Motolínea identified an indigenous bacbiller, born in Cuautla, as Miguel, a good Ladino. Ignacio Bernal believes that he was really the famous Valeriano de Azcapotzalco, who worked as a scribe/ translator on the Libro de los Colloquios for Fray Bernardino.

In the $1569^{10}$ Report of the Santo Evangelio Province addressed to Ovando, the objectives of completing the priests' work with the Santa Cruz students were clearly outlined. "Once some Indians knew Latin and were able to understand the mysteries contained in the Holy Scriptures, they could become more attached to the faith in order to transmit to others who were less prepared what the priests could not explain by themselves in the native tongues. They could then preach and interpret for them" [our translation].

The Ovando Report cited the permanent exchange of knowledge between Indians and priests, making the former not only ideal teachers of their own language but also the sole reliable judges for evaluating and amending the resulting texts. In doing so, they vigorously challenged claims about the so-called inferiority of the natives as compared to the Europeans, even though the translation of the sacred texts into common language according to the criteria of the time could not be more than an "interpretation": "Those who have learned their language are now the same as those that have been their teachers, learning to translate into that tongue what is written in their books, and they are now interpreting in the Hearings" ${ }^{\prime 11}$ [our translation].

The most outstanding graduates of Tlatelolco accomplished the cardinal duty of bringing linguistic support to the Christianization process with so much skill and quality that Fray Bernardino, their main mentor, did not hesitate to admit his dependence on his "grammarian residents" when any text needed to be translated "into correct vernacular Náhuatl." ${ }^{12} \mathrm{He}$ did not spare any praise when speaking of their work:

If they have succeeded in expressing sermons and postillas in a native tongue that could be considered purified of any heresy, it is because they have done work that fosters the proper understanding of Latin as well as the properties of the words and the means to express them. 
Besides, they are able to amend any inconsistencies in the sermons or texts to the point that anything that must be worded correctly in their language ought first to be evaluated by them. . . . ${ }^{13}$ [our translation]

The intuitive ability displayed by the Tlatelolco tutors as well as by their main mentor to carry out this twofold cultural intermingling is phenomenal. Addressing pastoral and academic concerns together as was done in the Toledo School allowed Fray Bernardino to produce more and more complete translations on the subjects treated in the Historia General, Sermonarios, Doctrina cristiana, Libro de los Colloquios, Vocabulario de tres lenguas, Psalmodia, and Postilla, to mention only his most famous works. He was also able to accomplish the final check of Sermonarios under the supervision of the trilingual translators and even make good use of their collaboration as amanuenses of his own writings, because his handwriting worsened due not only to age but also to the after-effects of the terrible Black Death plague that ravaged Mexico in 1545.

A detailed study compared the American versions of the sacred literature developed by Tlatelolco scholars with its sources in the Old and New Testaments. If we consider the omissions, additions, adaptations, and emphatic elements contained in the American version, it is possible to advance some interesting and fairly relevant theories about what the priests ascertained to be the most convenient way to introduce the Biblical texts, making them less shocking to the Indians of the New Continent. But it is also evident from the numerous handwritten copies and transcriptions of both historical and doctrinal texts aimed at facilitating their use, that manipulation and preservation were neither effected by the staff responsible for making the originals nor authenticated by Sahagún. That is why the texts are not necessarily free of additions, amendments, and interpretations of calligraphy. Depending on the culture of the curators in charge and their perception of the contents, some words were replaced by alleged synonyms. Those subsequent changes - that sometimes fit the context — were not always 
equivalent to what they replaced. Therefore, not all the extant versions are Santa Cruz originals; some are copies of copies.

At the same time, this huge and important translation and interpretation movement was of course part of the early stages of the Christianization process carried out by the priests as an essential complement to the Conquest. However, this movement was slowed and then finally aborted or concealed during the last quarter of the century because of the Ecumenical Council of Trent in 1564. This was in keeping with restrictive measures already adopted regarding Bible translation into the common languages. These measures had been adopted to counter the Protestant hardships endured by the Santo Oficio de la Inquisición Court, especially since those hardships had not resolved the still unforgotten old battle to make Castillan the "imperial language," displacing the common indigenous languages.

Furthermore, if we examine some comments concerning the translations of Sahagún's Psalmodia, for example, done by Tlatelolco students, it is obvious that the plurality of languages was indeed associated with the origin of the idolatries. Their origin was clearly associated with the New Testament account of the Pentecost "gift of speech" and with the conversion of the idols by Saint Matthew. Last but not least, is the parallelism, real or spurious, between the Tower of Babel and the Cholula Pyramid, which like the Biblical structure was also linked with divine punishment as well as with the multiplicity of languages and heresies. In 1570, in spite of their objectives and interests, the Crown and the Pope had no alternative but to declare Náhuatl, not Spanish, the official language in Nueva España.

An abstraction of the avatars suffered specifically in Sahagún's doctrinal and historical corpus was motivated by his disagreements with powerful members of the clergy, in the metropolis as well as in the Mexican Chapter, who put up serious obstacles to the spread of indigenous languages for reasons that had no connection with the Council of Trent. Five centuries later, we see a relative proliferation of manuscripts and versions of those still-unpublished texts. ${ }^{14}$ They were generated mostly in Santa Cruz de Tlatelolco, where an amazing staff of specialists was 
responsible for this outstanding example of high culture.

This huge body of work has been lost in transit between monasteries, libraries, private collections and archives around the world - consigned to obscurity, and with it any trace of its anonymous creators: the translators and interpreters who worked in the Imperial College of Santa Cruz de Tlatelolco in the sixteenth century. It has reappeared only recently, to be recovered and reassessed in every aspect, as it deserves to be.

LOURDES ARENCIBIA RODRIGUEZ

Universidad de la Havana

(Cuba)

\section{Notes \\ 1. The author would like to thank Kristen Guertin and Malcolm Williams for their thorough revision of this English version.}

2. In Rodriguez Lafuente (2001).

3. Bernardino de Sahagún. Apéndices a la Historia General. Chapter 5, Manuscript 1486 of the "Edmond E. Ayer" Collection (without page numbering), Newberry Library, Chicago.

4. Editor and translator of the Tratado de bechicerias y sortilegios by Andrés de Olmos, another famous priest who was Sahagun's contemporary.

5. "Aquí comienza la séptima admonición con la cual nuestra Madre, la Santa Iglesia Romana, amonesta a las gentes de aquí, de la Nueva España, acerca de los preceptos que antiguamente tenían cuando prometian a sus hijos para que ingresasen al calmecac o al telpochcalli ... por esto debeis ser instruídos y debeis ser informados, yo quiero referiros todo lo que yo se acerca de lo que se hacía allí cuando ingresaban al calmecac, al telpochcalli. Porque me lo dijeron los ancianos que allí habían sido señalados, que allí vivieron, todo lo que allí vieron cuando ya fueron bautizados, cuando se acercaron a Nuestro Señor Dios narraron lo que ahora quiero referiros para que no vivais inadvertidos acerca de lo que eran las costumbres en el calmecac o en el telpochcalli."

6. Constituciones del Imperial Colegio de Santa Cruz, Real Academia de la Historia. Col. Boturini, XIX, 101.

7. There were two sons of Moctezuma: don Pedro Motecuhzoma Tlacahuepan and don Martín Cortés Nezahualtecolotl; his brother Tezozómoc's children, 
don Francisco de Alvarado Matlacoahuatzin, and don Gaspar Tultequitzin; another relative in the second line of nobility; two Mexicas caciques, don Hernando de Tapia and Damián Tlacochcácatl; someone called don Gabriel, son of the latest king of Tlacopán Tetlepanquetzaltzin, don Jerónimo Conchano, a descendant of the kings of Tlatelolco; another of the kings of Culhuacán, don Baltazar Toquezquauhyotzin; don Juan Tzihuácmitl, himself a descendant of the Cempoalá monarchy; another of the lords of Cuitláhuac; don Felipe de Castilla Monialquatzin, a cacique belonging to the dignitaries of Tlamanalco; don Pedro de Castañeda Colomóchcatl $;$ and other knights and lords of the nobility of the country.

8. The priests had the monopoly on religious education until 1584 .

9. For example, the Arte $y$ vocabulario de la lengua mexicana by Fray Francisco Jiménez, quoted by Mendieta, had already been written when the first twelve priests arrived in Nueva España to evangelize the region.

10. García Izcalbalceta (1941 [1889]), II, 62.

11. Ibid., 62.

12.Sahagún (1956), III, 167.

13. Ibid., 635.

14.The Psalmodia Christiana (1583) was the sole text printed while the authors were alive.

\section{References \\ Primary sources}

\section{A. MANUSCRIPTS}

Museo de América, Madrid. "Codex Tro-Cortesiano." Fac. ed. Maya Culture, tenth century. . "Codex de Tudela." Fac. ed. Mexica Culture.

Real Academia de la Historia, Madrid. "Códice Matritense." Fac. ed. prepared by Francisco del Paso y Troncoso. Vol. VIII. Phototypography by Hausser and Menet. 1907 fol. 172 r-199v.

\section{B. PUBLISHED SOURCES}

Baudot, Georges. (1995). Utopia and History in Mexico: The First Chroniclers of Mexican Civilization (1920-1569), trans. Bernard R. and Thelma Ortiz de Montellano. Colorado: University of Colorado Press.

Cedulario del Perú siglos XVI, XVII y XVIII. (1948). Vol. II (1534-1538). Published by Raúl Porras Barrenechea. Colección de dos inéditos para la Historia del Perú. 
Cieza de León, Pedro. (1943). [1550]. Del Señorío de los Incas. Buenos Aires: A. Solar Eds.

Doctrina Cristiana en lengua española y mexicana por los religiosos de la orden de Santo Domingo. (1944). Reproduction of the Juan Pablo edition, Mexico 1548. Madrid: Ediciones Cultura Hispánica.

D'Olwer, Luis Nicolau. (1952). Fray Bernardino de Sabagun. México: Instituto Panamericano de Geografía e Historia (Historiadores de América 9).

Duviols, Pierre. (1977). La destrucción de las religiones andinas (durante la Conquista y la Colonia), trans. Albor Maruenda. México: UNAM.

Fernandez de Oviedo, Gonzalo. (1945) [1549]. Historia General y natural de los Indios. La Asunción: Guarani Ed.

Galich, Manuel. (2004). Nuestros primeros padres. La Habana: Casa de las Américas, Colección nuestros países.

García Izcalbalceta. (1889). Nueva colección de documentos para la Historia de Méjico. Vol. II. Reedited by Salvador Chávez Hayhoe, México, 1941. Códice Franciscano. Mexico, sixteenth century.

Garibay, Angel María. (1956). Prólogo a la Historia General de las cosas de Nueva España escrita por Fray Bernardino de Sabagún, franciscano y fundada en la documentación en lengua mexicana recogida por los mismos naturales, ed. Angel María Garibay K. Vol. I. Mexico: Ed. Porrúa.

Glass, John G. (1978). Sabagun's Reorganization of the Manuscript of Tlatelolco, 1566-1569. Massachussets: Conemex Associates.

Klor de Alva, Jorge. (1980). "The Aztec-Spanish Dialogues of 1524." Alcheringa. Ethnopoetics, 4:2.

León Portilla, Miguel. (1986). Coloquios y Doctrina Cristiana con que los doce frailes de San Francisco enviados por el papa Adriano VI y por el emperador Carlos V convirtieron a los indios de la Nueva España. Fac. ed. Spanish version and notes by Miguel León-Portilla. Mexico: UNAM and FISAC.

Molina, Cristóbal. (1968) [1552]. Relación de muchas cosas acaecidas en el Perú. Madrid: Biblioteca de Autores Españoles.

Porras Barrenechea, Raúl. (1986). Los cronistas del Perú 1528-1530. Biblioteca Clásica del Perú 12. Ediciones del Centenario. Banco de Crédito del Perú.

Rostworowski de Diez Canseco, Maria. (1988). Historia del Tabuantinsuyu. Instituto de Estudios Peruanos, Ministerio de la Presidencia. Consejo Nacional de Ciencia y tecnología CONCYTEC, Serie Historia Andina.

Sahagún, Fray Bernardino de. (1956). Historia General de las Cosas de Nueva España, ed. and prep. Angel Ma. Garibay K. 4 vols. Mexico: Porrúa Eds.

\section{INTERNET SOURCES}

Rodriguez Lafuente, Fernando. (2001). "La cultura en español e Internet." Paper presented at the Second International Congress of the Spanish Language 
Cervantes Virtual Center. cvc.cervantes.es ; www.congresodelalengua.cervantes.es

\section{Secondary sources}

Cline, Howard. (1973). "Sahagun, materials and studies, 1948-1971." In Handbook of Middle American Indians University of Texas Press.

Luna, Rosa. (1994). "La apropiación del otro a través de la traducción," Actas del Encuentro Nacional de Traductores. Lima: Universidad Ricardo Palma and Universidad Femenina del Sagrado Corazón.

Ramírez, José Fernando. (1903). "Códices mexicanos de fray Bernardino de Sahagún." In Boletín de la Real Academia de la Historia, 6, Madrid, 1885. Republished in Anales del Museo Nacional de Antropología, México, 2. 
This page intentionally left blank 


\title{
Glosas croniquenses:
}

\author{
A Synchronic Bilingual (American Indigenous \\ Languages - Spanish) Set of Glossaries
}

\section{Theoretical foundations}

G losas croniquenses is a project that exhibits a distinct postcolonial approach, in that it considers texts as discourses and criticizes those accepted as foundational by conventional historians and anthropologists. Native languages and Spanish, as they appear in those discourses, have been studied as languages in contact by Solano (1991, 1993) and Rivarola (1990), as well as by Rosenblat (1977) and Alvar (1970) among others. These scholars deal with ever-changing Royal linguistic policies, the emergence of Spanish dialects in the Andes, the impossibility of expressing Catholic dogma in native languages, and the influences co-existing languages had on each other. A fresh view on these authors has been the stepping stone for my research on early language conflict in America.

One strand of postcolonial theory validates the critical reading of early colonial documents about Tawantinsuyu, such as Antonio Cornejo-Polar (1994), who brought forward the concept of beterogeneity in relation to that of migration in order to initiate a discussion about this 
literature. These conceptual clarifications have been followed by those of Raúl Bueno (2004) regarding the crisis of occidentalization of indigenous populations. Also, beterologies as discussed by de Certeau in describing "discourses on the other" are quite useful theoretical developments to help pin down the core of traces that characterize the early texts by Spaniards on the Andean peoples and regions. I have left behind concepts like bybridism, transculturality, and mestizaje, since they tend to obliterate and obscure the violence of the cultural encounter between Europeans and indigenous peoples and the subsequent manipulation by Spaniards of their cultures, histories, and languages.

Early Spanish authors had to resort to the memory of living witnesses and kbipu keepers' recordings in order to fulfill their needs for written information. They were compelled to transform those personal memories and social registers into historicized texts, forcing them into chronological order. These texts have been through various processes in which intermediation has played a preponderant role. These processes include consecutive translation of the oral expression of the "general language" into oral Spanish. They also involve transfer from the knotted register of the khipu to the written one with ink on paper. If we follow chronological order, these processes will follow a sequence: the Spaniard asks a question in oral Spanish, the "lengua" or interpreter traduces into the "general language." The informants consult their kbipu and answer in "general language"; the interpreter translates the answer into oral Spanish; and a Spaniard writes it on a paper folio. We stand before a combination of translation and transcoding processes: information changes language and code while being recorded. Each one of these steps adds a dose of interference to the final message. Notwithstanding all these transformations, the texts contain valuable information about cultural aspects of past civilizations. They have to be reconsidered and re-evaluated, taking into consideration the amount of distortion intermediation processes generate, in order to adapt them to European historiography. The documents themselves have suffered mutilations, loss, deterioration due to humidity and worm damage, besides being subjected to other disasters such as fire, earthquakes, and 
wars. Some of those documents, once thought to be originals, have since been identified as copies or dictated versions written down by semi-literate scribes, with all the ensuing errors in encoding that might be expected. Glosas croniquenses is also based on Andean linguistics, a discipline dedicated in part to the recovery of the lexical and semantic patrimony of Andean languages. It should be noted that these glossaries spring from texts written in the Spanish language. Native words which appear in those texts are identified as "Americanisms" and they are studied by philologists as loans to Spanish. The Diccionario de la Real Academia de la Lengua Española has two entries, the fifth and the sixth, which can help us define "Americanism." To begin with: "Word, turn, phonetic, grammatical or semantic trace belonging to any American indigenous language or deriving from it" [my translation]. In this understanding, American indigenous languages have passed into Spanish and are identified as alien. The other entry: "Word, turn, phonetic, grammatical or semantic trace which is characteristic of or proceeds from the Spanish spoken in any American country" $(1992,89)$. This definition refers to the special form acquired by Spanish in America, that is, its dialectalization. It also denotes the language in which the texts studied have been written: a Spanish charged not only with traces, but with indigenous lexical items, besides other defining characteristics.

This project deals with these "Americanisms" from a postcolonial perspective $_{;}$this project deals with those "Americanisms" as American indigenous language patrimonial words which appear in Spanish discourses as a consequence of a particular event in time. The authors who used them believed that in so doing they would better explain the American territory to their European readers and also add exoticism to their descriptions. I believe that these indigenous terms form the core of the languages spoken in America when the Spanish invasion took place. Their study offers many opportunities to attempt the reconstruction of numerous native cultural features that have not been well understood or interpreted since the sixteenth century. Besides, it is of the utmost importance to incorporate native words and meaning into the linguistic resources of each indigenous language or idiomatic variety. 
Some researchers have developed glossaries, generally placing them at the end of their editions of colonial texts, but they have added contemporary explanations to the old entries in Quechua or in other native languages. This temporal overlapping distorts synchronic meanings, while at the same time contributing to the dissemination of erroneous interpretations of life in Tawantinsuyu, different from those observed by the first Europeans, and different also from what has been confirmed by archaeology, history, and linguistics. Lexicographers such as Baldinger (1989) register the first time a word appears in manuscripts or in print and also identify the selected words' etymology, without grouping them according to language.

There is an important work on the lexicology of the sixteenth century, written by Peter Boyd-Bowman in 1972: Léxico bispanoamericano del Siglo XVI, which has recently been copied in a CD format for computer viewing. His emphasis is on building a paradigm of Spanish words used in that period as they appeared mainly in bureaucratic and legal manuscript documents. Baldinger's work and that of Boyd-Bowman are the closest endeavours to my own, though they differ in an important way: they are meant to familiarize the historical or anthropological researcher with the lexical items used in the Spanish language of the period. Their work, then, stems from an interest in the Spanish lexicon of the times, not in indigenous ones.

In the line of early Vocabularies and Grammars of native languages, we have excellent examples in those of Domingo de Santo Tomás (1560) and Diego González Holguín (1608), among others. Their aim was to appropriate Quechua words and phrases to aid them in their project of catholization and evangelization in indigenous languages.

On the other hand, the incessant search for indigenous languages' grammatical, morphological, and semantic characterizations through Spanish writers' testimonies has been the task of Rodolfo CerrónPalomino for many years. He has advanced Quechua (1987), Aimara (2000), and lately, Puquina linguistics, opening new avenues of explanation and understanding of toponyms, patronyms, and nomenclatures that would otherwise be obscure. 
Anthony Pym's idea of intersection (2000) also provides momentum in dealing with texts that exhibit great examples of multilingualism, and allows for better explanations of specific issues such as sub-lation (Niranjana 1992) and "traffic" of meanings and significations (Pratt 2002). Schleiermacher's notions of foreignness and domesticity (1992) help us understand the position of the translator regarding both the original and his own version. Enguita Utrilla's classification of translation techniques (1996) has been quite useful in delineating the initial, basic approaches to translation activities in the second half of the sixteenth century in the Andean region. Invaluable insights have been provided by César Itier's sophisticated research (1995) into manipulatory translation activities, especially by Spanish friars dealing with catholization strategies and techniques.

As future tasks of the project, the following appear to be the most urgent. The need for expanding concepts like cultural and linguistic translation in a colonial context is evident. More research has to go into the strategies of conveying meaning in two languages simultaneously, the problematics of perception and representation, and the study of early chronicles as bicultural and bilingual documents. Research into the process of transcoding, that is, of the delivery of what is contained in one code into another, for example, from oral to written, from kbipu to oral and to written, also needs to be initiated and pursued.

\section{Objectives}

The aim of Glosas croniquenses is the identification and recuperation of the lexical and semantic patrimony of indigenous languages, prioritizing Andean ones. These linguistic items will expose ideas and concepts pertaining to the Andean realm in pre- and post-Conquest times. It is a contribution to the extension and deepening of indigenous languages' idiomatic resources, enriching their actual linguistic bases.

A further priority is the contextualized registration of the Spanish equivalents of indigenous patrimonial terms even though the context in question is a Spanish one. The sixteenth century is a relevant period 
because the language contact was recent, between fifteen and forty years old. Thus, indigenous languages had been less exposed to the influence of the Spanish language. Insofar as it is possible, the cultural sphere of the use of those words will also be provided. The early Spanish descriptions of life in the Andean region constitute a complex yet unique source for the history and the study of cultural issues of the vanishing Inca civilization, and also the traces of pre-Inca cultural remains.

The early writers of the texts that comprise Glosas croniquenses were witnesses of what they described and could relate to their surroundings for confirmation or confrontation of their informants' reports. They had first-hand information and are primary sources for the study of the period from historical, linguistic, and cultural perspectives.

Yet another aim is to develop a better comprehension of the bicultural nature of the narrative, starting with what Spaniards intended to describe and explain to their European readership, underlining issues of culturally based perception and description. Also, it should not be overlooked that indigenous protocols of the spoken word were ignored (Fossa 2002b) when the questioning of informants was practiced.

The identification of each specific indigenous language is of primary importance here, since many words were either not identified by their Spanish users, or were wrongly attributed to a "general" language. This identification implies a normalization of indigenous terms, especially since they were being representated in alphabetic writing for the first time, resulting in several forms for the same word or words. So far, the identified indigenous languages used by Spaniards in texts written in the sixteenth century in the Andes are Quechua, Aimara, Puquina, Taino, Kuná, and Náhuatl.

Each bilingual entry allows for the identification of translation strategies in use in the sixteenth century. Interlinguistic equivalences are the most common, but several others are also present.

As a series of electronic primary sources, Glosas croniquenses seeks to attract future contributors of new texts and glossaries. Every sixteenthcentury text dealing with the Andean region is a potential source of 
native terminology and its equivalents. Thus, the project should be in continuous growth, having numerous contributors and a permanent administrative body to monitor and modulate that growth.

Last but not least, Glosas croniquenses should generate enthusiasm from funding agencies and institutions dedicated to the support of innovative research in Andean indigenous linguistics. Their help is needed to provide breadth and depth to the project as it currently exists.

\section{Description}

As indigenous lexical items are identified in the Spanish texts, a series of bilingual, synchronic, indigenous languages-Spanish glossaries-are being constructed. Toponyms are included since they offer not only semantic but also geographic and historical linguistic information ${ }_{i}$ they will therefore also help trace the expansion of different cultures, with different languages, through Andean territory. Patronyms form an important part of the glossaries from a dual perspective. On the one hand, they offer semantic meaning, and on the other, specialists still have difficulties in determining if they designated members of one family or if they were honorific titles used only with certain types of officers. Some words in Spanish have been included, when they refer to indigenous cultural objects or functions. Because of this, the glossaries will house the descriptions and definitions corresponding to those items that would otherwise be lost. In some of the glossaries the user will also find a column with the entry from the respective manuscript. Those entries sometimes differ from the ones in the edited work. They are important from a linguistic point of view and also serve as a guide in the linguistic identification of the indigenous term.

Each entry is made up of the indigenous term as it was published and, when needed, the term in the manuscript, phonologic transcription, language identification, and a citation which carries the equivalence, meaning, and description in Spanish. The preparation of all this information has been supported by the ability of specialized professionals in linguistics, computer programming, paleography, discourse analysis, and 
history. Regarding the phonologic transcription, I would like to say that this graphic representation is a reconstruction based on the Quechua alphabet officialized in Peru in 1985 (Godenzzi 1987, 41). I believe it is important to add this information because we have found much instability in the way native words have been registered, and consequently in the variety of ways in which they are written in the texts. The graphic representation corresponds to the underlying form of the many ways in which one word appears in texts and manuscripts. This form represents the sounds heard, that is, what the author wanted to write.

The inclusion of Spanish words describing peoples, officers, and indigenous institutions was decided because many of them are known by their Spanish nicknames: "orejones," "parcialidades," "provincias." These terms are "partially" Spanish, in the sense that only the signifiers are of that origin. The content is native, even though the native word that identifies it is omitted. The proposal of including these mixed terms is based in the concept of the linguistic sign, defined as:

una unidad del plano de la manifestación, constituída por la relación de presuposición recíproca que se establece entre las magnitudes del plano de la expresión (o significante) y del plano del contenido (o significado) durante el acto de lenguaje" (a unit of the manifestation plane constituted by the relationship of reciprocal presupposition established between the magnitudes of the expression plane [or signifier] and of the content plane [or signified] during the act of language) [our translation]. (Greimas and Courtès 1985, 376).

This definition refers to only one language, of course, the most common instance. But in a special situation of language contact as that of colonization, complex signs appear such as the ones I am describing now, in which the signifier belongs to one language, that of the colonizer, and the signified to another one, that of the colonized. A reversal of this situation is also common: the signifier is indigenous and the signified European. 
Identified words in the native languages usually appear in early texts written by Spaniards along with their explanations or equivalencies in Spanish. The basic unit of study is thus the lexical bilingual pair, synchronic, of the sixteenth century. This is an important time period due to the recentness of the Spanish presence in the area. With the informed help of Marco Ferrel, a linguist specialized in Andean languages, lexical items in the glossaries that form this project have been identified as pertaining not only to Quechua and Aimara, but also to Puquina, Kuná, Taino, Náhuatl, and others.

The project relies on computer programming to produce flexible and open lists that allow for continous revisions by the project's teams. The word lists are available through the Internet and can be easily accessed for consultation and study. Also, the glossaries' administrators have the possibility and the capacity to continually adjust the material presented.

The Internet is used to house these glossaries because of its low cost and easy international access. In low-technology countries it is possible to access the glossaries through public computing centres. Bearing that in mind, we have used a format that minimizes illustrations, avoiding heavy files and resorting to simple programs which take up little computer memory. This makes it very easy to access and consult the glossaries quickly.

Databases can be used independently or in clusters, combined according to the researchers' needs. Information about a single term in all the authors can be obtained, as well as a selection of terms within a single author, and all combinations in between. Users can adapt databases to their research requirements and prepare shorter lists through a selection of data to produce the fusions and combinations needed. Lists can also be printed from the Internet.

\section{The project's development}

This project started, under a different name, in 1997 with a grant from the Humanities Research Initiative of the University of Arizona. It was consolidated in 2000 with a second grant from the same entity. Glosas 
croniquenses also received a Small Grant from the Office of the Vice President for Research and further funding from the College of Humanities and the Department of Spanish and Portuguese of the University of Arizona.

Glosas croniquenses' first phase includes three glossaries (see Appendix 1) and will soon be completed when one of the larger glossaries, that of Juan de Betanzos, undergoes a final revision.

The second phase contains three texts (see Appendix 2) and is also nearing completion. Both phases are already on the Internet, and Zárate's glossary will be undergoing a general revision. The first steps in the construction of Hernando Pizarro's glossary have been taken; that will be the shortest so far.

The third phase will start with glossaries that will be elaborated from texts belonging to Licenciado Francisco Falcón, soldier Pedro Pizarro, and Friar Bartolomé Alvarez.

GLOSSARY TABLE

\begin{tabular}{llc}
\hline Author's NAme & Title & MANUSCRIPt Date \\
\hline $\begin{array}{l}\text { Francisco Falcón } \\
\text { Pedro Pizarro }\end{array}$ & $\begin{array}{l}\text { Daños y molestias que se hacen a los Indios ... 1560? } \\
\text { Relación del Descubrimiento y } \\
\text { Conquista de los Reinos del Perú } \\
\text { Be las costumbres y conversión de los } \\
\text { indios del Perú }\end{array}$ & 1571 \\
\hline
\end{tabular}

The third phase and pending tasks of the two previous phases are in need of funding in order to be completed, but this project is already a great success (see Appendix 3).

LYDIA FOSSA

(Peru) 


\section{References}

Alvar, Manuel. (1970). Americanismos en la "bistoria" de Bernal Díaz del Castillo. Centro Superior de Investigaciones Científicas. Revista de filología española, Anexo LXXXIX. Madrid.

Alvarez, Bartolomé. (1998). De las costumbres y conversión de los indios del Perú. Memorial a Felipe II [1588], ed. María del Carmen Martín Rubio, Juan J. R. Villarías Robles, and Fermín del Pino Díaz. Madrid: Polifemo.

Baldinger, K. (1989). "Vocabulario etimológico." In Crónica del Perú. Tercera Parte, ed. F. Pease. Lima: Pontificia Universidad Católica del Perú, 331-395.

Betanzos, Juan de. (1987). Suma y narración de los Incas (1551), ed. María del Carmen Martín R. Madrid: Atlas.

Bueno Chávez, Raúl. (2004). Antonio Cornejo Polar y los avatares de la cultura latinoamericana. Lima: Fondo Editorial de la UNMSM, Serie Humanidades.

Boyd-Bowman, Peter. (2003). Léxico bispanoamericano 1493-1993, CD ROM.

Cerrón Palomino, Rodolfo. (2000). Linguiística aimara. Cuzco: CERA Bartolomé de las Casas.

Linguística Quechua. (1987). Cuzco: CERA Bartolomé de las Casas and GTZ.

Cieza de León, Pedro. (1985). Crónica del Perú. Segunda Parte, El señorío de los Yngas, ed. F. Cantù. Lima: Pontificia Universidad Católica.

Cornejo Polar, Antonio. (1994). Escribir en el aire. Ensayo sobre la beterogeneidad sociocultural en las literaturas andinas. Lima: Horizonte.

Diccionario de la lengua española, (1992). Madrid: Real Academia de la Lengua-21a Ed.

Enguita Utrilla, José M. (1996). "Indoamericanismos léxicos en algunos textos relativos a la conquista y colonización del Nuevo Mundo." In Studia Neopbilologica, LXVIII:2, 233-243.

Falcón, Francisco. (1946). "Representación hecha por el Licenciado Falcón en Concilio Provincial sobre los daños y molestias que se hacen a los indios," in Los pequeños grandes libros de bistoria americana, intro., notes, and comments by Francisco A. Loayza. Series I, Vol. X. Lima.

Fossa, Lydia. (2001). Glosas croniquenses: el mundo andino en quechua y castellano. Notables daños de no guardar a los indios sus fueros (Polo Ondegardo's glossary). http://www.coh.arizona.edu/spanish/FossaLydia/Ondegardo/Ondegardo. html

. (2002a). Glosas croniquenses: el mundo andino en quechua y castellano. El señorìo de los Incas, Segunda Parte de la Crónica del Perú (Pedro de Cieza de León's glossary). http://www.coh.arizona.edu/spanish/FossaLydia/Cieza/Cieza.html

- (2002b). "L'interlocution dans la culture andine." In Histoire et sociétés de l'Amérique Latine. Revue de ALEPH: Amérique Latine Histoires, 13 (2001-1). Paris: Harmattan, 99-117. 
. (2004a). Glosas croniquenses: el mundo andino en quecbua y castellano. Gobierno del Perú (Juan de Marienzo's glossary). http://www.coh.arizona.edu/spanish/ FossaLydia/Matienzo/todo.htm

- (2004b). Glosas croniquenses: el mundo andino en quecbua y castellano. Historia del descubrimiento y conquista de las provincias del Perú (Agustín de Zárate's glossary). http://www.coh.arizona.edu/spanish/FossaLydia/Zarate/todo.htm

- (2004c). Glosas croniquenses: el mundo andino en quecbua y castellano. Suma y narración de los Incas (Juan de Betanzos's glossary). http://www.coh.arizona. edu/spanish/FossaLydia/Betanzos/Betanzos.html

Godenzzi, Juan Carlos. (1987). Lengua, cultura y región. Diálogo y conflictos en el sur andino peruano. Cuzco: Centro Bartolomé de las Casas.

González Holguín, Diego. (1989). Vocabulario de la lengua Qquicbua o del Ynga. Lima: 1st ed. 1608, Francisco del Canto. 2nd fac. ed. 1952, UNMSM. 3rd. fac. ed. UNMSM.

Greimas, A. J., and J. Courtès. (1985). Semiótica. Diccionario razonado del lenguaje, Spanish version by H. Campodónico y E. Ballón. Madrid: Ed. Gredos.

Itier, César. (1995). "La littérature quechua d'évangélisation (XVIe et XVII siècles) comme source ethnolinguistique." In Amérindia. Revue d'etbnolinguistique amérindienne, 19:20. Paris: SELAF, 321-330.

Matienzo, Juan de. (1967) [1567]. Gobierno del Perú con todas las cosas pertenecientes a ély a su bistoria, ed. and preliminary study by G. Lohmann Villena. Vol. XI. París-Lima: IFEA.

Niranjana, Tejaswini. (1992). Siting Translation: History, Post-Structuralism and the Colonial Context. Berkeley, Los Angeles, Oxford: University of California Press.

Ondegardo, Polo. (1990). Notables daños de no guardar a los yndios sus fueros . . . [1571] (El mundo de los incas), ed. Laura González and Alicia Alonso. Madrid: Historia 16.

Pizarro, Hernando. (1533) [1921]. "A los magníficos señores los señores oidores de la Audiencia Real de Su Magestad que residen en la ciudad de Sancto Domingo." Revista Histórica, 167-180.

Pizarro, Pedro. (1986). Relación del descubrimiento y conquista de los reinos del Perú. G. Lohmann (ed. and Preliminary Considerations). P. Duviols (Note). Lima: PUCP.

Pratt, Mary Louise. (2002). "The Traffic in Meaning: Translation, Contagion, Infiltration." In Profession 2002. Modern Language Association of America (MLA) Journal, 25-36. New York.

Pym, Anthony. (2000). "On Method in Hispanic Translation History," Paper presented at the $\mathrm{V}$ Jornadas Internacionales de Historia de la traducción, Universidad de León, 28-31 May.

Rivarola, José Luis. (1990). La formación lingüística de Hispanoamérica: diez estudios. 
Pontificia Universidad Católica del Perú. Lima: Fondo Editorial.

Rosenblat, Angel. (1977). Los conquistadores y su lengua. Caracas: Ed. de la Biblioteca, Universidad Central de Venezuela.

Santo Tomás, Domingo de. (1560). [1951]. Lexicon o vocabulario de la lengua general del Perú. Valladolid: Fernández de Córdova, Lima: (fac. ed.). UNMSM.

Schleiermacher, Friedrich. (1992). "From On the Different Methods of Translating." In Theories of Translation: An Antbology of Essays from Dryden to Derrida. Oxford University Press.

Solano, Francisco de. (1991). Documentos sobre política linguística en Hispanoamérica (1492-1800). Madrid: CSIC.

. (1993). "Aprendizaje y difusión del español entre indios (1492 / 1820)."

In Langues et cultures en Amérique espagnole coloniale. Paris: Presses de la Sorbonne Nouvelle, 291-321.

Zárate, Agustín de. (1995). Historia del descubrimiento y conquista del Perú. Pontificia Universidad Católica del Perú. Lima: Fondo Editorial.

\section{Appendix 1}

First phase glossaries

\section{FIRST PHASE GLOSSARIES}

\begin{tabular}{llc}
\hline Author's Name & Text Title & Manuscript Date \\
\hline Juan de Betanzos & $\begin{array}{l}\text { Sumay narración } \\
\text { Crónica del Perú. Segunda Parte. }\end{array}$ & $1551-1564[+]$ \\
Pedro de Cieza & $\begin{array}{l}\text { El señorio de los Incas } \\
\text { Notables daños de no guardar a los } \\
\text { indios sus fueros... }\end{array}$ & 1550 \\
& & 1571 \\
\hline
\end{tabular}

These glossaries have been available for international consultation since:

FIRST PHASE GLOSSARIES ON THE WEB

\begin{tabular}{ll}
\hline Author's NAme & ON THE Web SINCE \\
\hline Juan de Betanzos & 22 September 2003 \\
Pedro de Cieza & 31 October 2002 \\
Polo Ondegardo & 28 March 2001 \\
\hline
\end{tabular}




\section{THEY ARE LOCATED AT:}

http://www.coh.arizona.edu/spanish/FossaLydia/Betanzos/betanzos.htm (2004) http://www.coh.arizona.edu/spanish/FossaLydia/Ondegardo.html (2001) http://www.coh.arizona.edu/spanish/FossaLydia/Cieza/Cieza.html (2002)

\section{Appendix 2}

SECOND PHASE TEXTS

\begin{tabular}{lll}
\hline Author's Name & Text Title & Manuscript Date \\
\hline Juan de Matienzo & Gobierno del Perú & 1575 \\
Agustín de Zárate & Historia del descubrimiento y conquista & \\
& delas provinçias del Peru... & 1555 \\
Hernando Pizarro & Carta a los Magníficos Señores & 1533 \\
\hline
\end{tabular}

These glossaries have been available for international consultation since:

\section{SECOND PHASE GLOSSARIES ON THE WEB}

\begin{tabular}{ll}
\hline Author'S NAME & ON THE WEB SINCE \\
\hline Juan de Matienzo & 22 February 2004 \\
Agustín de Zárate & 22 September 2003 \\
Hernando Pizarro & - \\
\hline
\end{tabular}

\section{THEY CAN BE FOUND AT:}

http://www.coh.arizona.edu/spanish/FossaLydia/Zarate/todo.htm (2004) http://www.coh.arizona.edu/spanish/FossaLydia/Matienzo/todo.htm (2004)

\section{Appendix 3}

In total, the project has received over 2,700 visits since 2001. Detail of these numbers as per October 7, 2004: 
VISITS TO GLOSSARY SITES SINCE 2001

\begin{tabular}{lrlr}
\hline Glossary & VISITS & GLOSSARY & VISITS \\
\hline Juan de Betanzos & 677 & Juan de Matienzo & 246 \\
Pedro de Cieza & 1,185 & Agustín de Zárate & 353 \\
Polo Ondegardo & 1,521 & Hernando Pizarro & --- \\
Total & & & \\
\hline
\end{tabular}

Some of the visitors express in writing their positive reactions on viewing the glossaries, and using them in their research projects.

- In April 2000, I presented the project and the initiation of the first phase with Polo Ondegardo's glossary to the Symposium on Edition and Annotation of Andean Texts at Harvard University. The symposium presentations were published as a book: Edición y anotación de textos andinos in 2000.

- In February 2001, I gave a presentation stressing Ondegardo's glossary more than the overall project, at the Eleventh Annual Graduate Student Symposium at the University of Arizona.

- In May 2004, I presented a more mature project with six authors online at the Translation and the Future of History Conference organized by the Canadian Association for Translation Studies, in Winnipeg.

- In October 2004, I presented Glosas croniquenses to a group of Pontificia Universidad Católica del Perú students.

- I believe it is important now to continue communicating the expansion of Glosas croniquenses among interested scholars. I plan to write a series of letters to colleagues around the world informing them about this useful research tool. I am also approaching funding agencies and institutions for future financing. 
This page intentionally left blank 


\section{Translating the New World in Jean de Léry's \\ Histoire d'un voyage fait en la terre du Brésil}

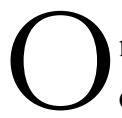

ne of the effects of translating a historical text years, even hundreds of years after its initial publication is the continued life given to it by the translation. The work lives on in its translation. The voices contained within the text are revived and returned to circulation. We shall see this occur in Janet Whatley's 1990 translation of a book first published in 1578, Jean de Léry's Histoire d'un voyage fait en la terre du Brésil. The book describes Léry's voyage, part of an early attempt by France to establish a colony in the New World, and his contact with the Tupinamba Indians of Brazil. I shall focus on the chapters relating to the plants and animals of the New World, as they allow us to find traces of indigenous voices within both the original and its translation.

Because the Americas constitute a distinct land mass from Eurasia and Africa, the indigenous plant and animal species had never been seen by Europeans prior to their arrival on the continent. The natural environment - full of unfamiliar flora including tomatoes, chilies, potatoes, manioc, vanilla, tobacco, and chocolate, and fauna such as jaguars, 
raccoons and skunks - represented quite literally a new world to them. Travellers commonly collected specimens of exotic flora and fauna from the Americas and brought them back to Europe. Indeed, the ship on which Jean de Léry returned to France was loaded with parrots, monkeys and other items that were rare in Europe; but the voyage was so arduous the sailors were forced to eat everything, including their specimens, to ward off starvation. Names for these native species existed in indigenous but not in European languages. In the literature of explorers and early colonists, we can trace the process by which words for New World species were incorporated into the colonizers' languages.

\section{The voyage and Léry's account}

Jean de Léry's Histoire d'un voyage fait en la terre du Brésil is an account of the French colonizing mission to the New World in 1556-58. After Brazil was discovered by Portuguese explorers in 1500, Portuguese and French traders sailed the Brazilian coast, harvesting forest products such as brazilwood and shipping them back to Europe. They traded with the Tupinamba Indians, who lived along the coast. Whereas the Portuguese sought to subjugate the Tupinamba and put them to work, the French had more cordial relations with them, based on mutual benefit (Whatley 1990, xix). Between 1555 and 1565, France made several attempts to establish permanent colonies in Brazil and Florida; all ended in failure as the colonies fell to the Portuguese and Spanish.

In 1555, Nicolas Durand de Villegagnon led an expedition to Brazil and founded Fort Coligny on a small island at the site of what is now Rio de Janeiro, calling the settlement "France Antarctique" (Lestringant 1996). A second ship arrived a year later, carrying thirteen Huguenots - French Protestants - seeking refuge from religious persecution. One of those was Jean de Léry, who had gone to Geneva to study the Reformed Gospel under Calvin. Although Villegagnon, a Catholic, had allegedly appealed to Calvin to send over the Protestant missionaries and promised them religious freedom, he appears to have been a tyrannical and violent man who plotted against his compatriots. After eight 
months, Léry and his fellow Protestants realized they were unsafe on the island base and fled to the mainland, where they lived among the Tupinamba for two months until the next ship, loaded with brazilwood, returned to Europe (Whatley 1990, xv-xxii). Those experiences formed the basis of Léry's account, to which he added his vivid, detailed observations of the Tupinamba and the indigenous flora and fauna.

Histoire d'un voyage fait en la terre du Brésil was first published in 1578 in Geneva, twenty years after Léry's return to Europe, based on the memoirs he had kept in America. The period in France following his return was marked by the Religious Wars, and Léry witnessed episodes of violence and inhumanity that went beyond anything he had observed among the Tupinamba, including cannibalism. In 1573, he suffered through the siege of Sancerre by royal Catholic forces; later, he wrote a book on the experience that displays the same ethnographic concern as his travel narrative, treating not only moral questions but also the practicalities of daily life in an extreme situation (Whatley 1990, xvii-xviii).

Histoire d'un voyage was an immediate success, with five French and two Latin editions appearing during Léry's lifetime. In Latin, it was part of the Grands Voyages collection published by Theodor De Bry and his sons, which was extensively illustrated with copperplate engravings. The collection was widely disseminated in an attempt to generate support for a Protestant colonizing project in the New World that would compete with that of Catholic Spain and Portugal. Subsequent re-publications in French included an annotated edition by Paul Gaffarel (1879), a critical edition and facsimile of the text by Jean-Claude Morisot (1975), and a modernized French version published in 1980 by Sophie Delpech. However, it was through Claude Lévi-Strauss that Histoire d'un voyage gained wider attention, even canonization. Calling it a "masterpiece of anthropological literature" (Lévi-Strauss 1963, 88), he carried it with him on his first voyage to Brazil:

Once ashore, I ambled along the Avenida Rio Branco, where once the Tupinamba villages stood ${ }_{i}$ in my pocket was that breviary of the 
anthropologist, Jean de Léry. He had arrived in Rio three hundred and seventy-eight years previously, almost to the day (Lévi-Strauss 1963, 85).

In the French-speaking world, interest in Histoire d'un voyage grew, particularly after the publication of Tristes Tropiques in 1955. Developments in historiography, such as the Annales school's focus on everyday life and Michel Foucault's analysis of knowledge and discourse, as well as Michel de Certeau's reflections on the writing of history, led to increased appreciation of Léry's ethnographic contribution. However, it was not until 1990 - over four hundred years after its initial publication - that Léry's account received a full English translation. In the years leading up to the 1992 quincentenary of Christopher Columbus's arrival in the New World, there was renewed scholarly interest in the ethical and ethnographic issues surrounding the colonization of the Americas, evident in the work of Tzvetan Todorov and Stephen Greenblatt, among others. The translation by Janet Whatley, Professor of French at the University of Vermont, grew out of that context. ${ }^{1}$

Prior to Whatley's translation, Histoire d'un voyage had been partially translated into English in 1611, and several chapters were translated into English and published in 1625 as part of Samuel Purchas's collection of travel manuscripts entitled Hakluytis Postbumus or Purchas His Pilgrimes. England's attempts to establish a presence in the New World lagged behind those of Spain, Portugal and France, and it was not until 1607 that England founded a permanent colony in Virginia, seeking to stake out a claim to the continent's natural resources. The Purchas translation can be seen in the context of early English imperialism and efforts to take possession of North America. It reflects the language of the time: most noticeably, the Tupinamba - whom Léry calls "les sauvages" are referred to as "the Barbarians" (Purchas 1625 [1965]). Yet even in the seventeenth century, "Barbarians" was not the only word for native people; other English writers contemporary with Purchas referred to them as "the inhabitants" or "the Indians," notes Nancy Senior in a discussion of the difficulties of translating words like sauvage in a historical text 
(Senior 2004, 466-469). Janet Whatley translates sauvage as "savage," explaining in a footnote that the French word does not have the same primary connotation of cruelty as its English cognate (Whatley 1990, 232). In addition, Léry frequently uses "nos sauvages" and "nos Ameriquains," a familiar form of address that is refused in the 1625 Purchas translation (where only "the Barbarians" and "the Americans" are used) but maintained in Whatley's 1990 translation ("our savages" and "our Americans").

\section{The wonder of the New World}

Histoire $d^{\prime}$ 'u voyage is one of a number of accounts of European voyages to the New World during the early period of contact and colonization. It is viewed by Frank Lestringant, following Marcel Bataillon, as part of a "Huguenot corpus on America," texts by French Protestants that were characterized by a denunciation of the Spanish Conquest and a defence of the free savage (Lestringant 1991, 200-201). These disparate texts later became the point of departure for the myth of the Noble Savage. But although Léry expressed admiration for the moral virtues of the Tupinamba, he did not idealize them ${ }_{i}$ his view was tinged with pessimism and remorse, for all his attempts to convert them had failed and he believed nothing could be done to save them from eternal damnation.

Many accounts describing early encounters with the New World are characterized by both astonishment at the newness of everything the writers observed and a need to relate the experience to European terms of reference. This is evident as far back as Christopher Columbus's diaries: he repeatedly uses the words "wonder" and "marvellous" to describe what he saw, from fish to parrots to landscapes (Greenblatt 1991, 72-85). Confronted with the extreme otherness of the lands they were encountering, the explorers may have been attempting to tame that very otherness by describing it with wonder and delight and emphasizing the bountiful natural resources. If nature was marvellous, it could not be formidable, inaccessible, frightening or grotesque. At the 
same time, readers of sixteenth-century travel books, influenced by descriptions such as those in Sir John Mandeville's tales of "folk of diverse shape and marvellously disfigured" (Mandeville [1499] 1900, 132), expected them to be populated with marvels and monsters. Whereas accounts by Mandeville and Marco Polo located the wonders in the East, by the sixteenth century their domain had shifted to the Americas (Gagnon 1984, 46).

André Thevet, a chaplain with Villegagnon's expedition who had been in Fort Coligny prior to Léry's arrival and published Cosmograpbie universelle in 1575, speaks of seeing giants and Amazons and is frequently cited in Ambroise Parés Des monstres et prodiges (1579; see Paré 1971). But Léry questions Thevet's accounts — indeed, a heated rivalry set in between the two - and suggests that Thevet filled his book with nonsense to lengthen and exoticize it (Céard 1971, xvi). Léry insists on how utterly unlike what he observes is to anything in Europe ("everything to be seen - the way of life of its inhabitants, the form of the animals, what the earth produces - is so unlike what we have in Europe, Asia, and Africa that it may very well be called a 'New World' with respect to us" [Léry 1990, 1x-lxi]), but he is careful to write only of his observations and to remain credible. He insists that the Tupinamba Indians are "not taller, fatter, or smaller in stature than we Europeans are; their bodies are neither monstrous nor prodigious with respect to ours" (Léry 1990, 56).

This insistence on recording only what he himself had experienced, seen, heard and observed, what he had touched, smelled and eaten "and therefore seen both the inside and the outside" [Léry 1990, 16]) pervades Léry's account. He was scornful of hearsay and preferred first-hand experience to knowledge gained through reading books. In this respect he differed from André Thevet, who spent only about ten weeks in Brazil and supplemented his experience with second-hand sources, for which Léry castigates him roundly. On several occasions, Léry disputes Thevet's claims by giving primacy to his own observations: 
Before I finish this discussion of parrots, being reminded of what someone says in his Cosmograpby, that they build their nests hanging from a tree branch so the snakes don't eat their eggs, I will say in passing, having seen the contrary among those in the land of Brazil, all of which build their nests - round in shape, and quite tough — in the hollows of trees, that I judge this to be one of that author's cock-andbull stories. (Léry 1990, 89)

In this respect Léry was going against the dominant intellectual climate of sixteenth-century France, which revered written authority, especially that of the ancients such as Aristotle and Pliny (Mackenzie 2001). Léry places direct experience above theory or book learning, insisting time and again on the value of what he observed. For example, although at the time porpoises were classified as fish, which reproduce through egg-laying, he noticed that some of the porpoises killed by the sailors had young developing in their uteri, like cows. He states defiantly, "Even though I would not make any decision here, lest anyone would argue the point by citing to me those who have firsthand experience - rather than those who have only read books - no one will meanwhile prevent my believing what I have seen." (Léry 1990, 18)

\section{Writing and the Tupi language}

Despite Léry's insistence on the value of experience, he recognized that knowledge of writing set him and the rest of the colonists apart from the Tupinamba. Like the other indigenous peoples of the Americas, theirs was a "primary oral culture" in that they had no knowledge whatsoever of alphabetic writing (Ong 1982, 11). Léry describes their reaction to seeing the French write:

They know nothing of writing, either sacred or secular ${ }_{i}$ indeed, they have no kind of characters that signify anything at all. When I was first in their country, in order to learn their language I wrote a number of sentences which I then read aloud to them. Thinking that this 
was some kind of witchcraft, they said to each other, "Is it not a marvel that this fellow, who yesterday could not have said a single word in our language, can now be understood by us, by virtue of that paper that he is holding and which makes him speak thus?" (Léry 1990, 134-135)

To Léry, the art of writing is an advantage held by the people of Europe, Asia and Africa over those of the fourth part of the world, America. It allows them to learn through books and communicate with people in distant places; it is a gift of God (Léry 1990, 135). As a Protestant and Calvinist, he considers writing to be a medium of retention that allows the truth of Scripture to be preserved and transmitted (Whatley 1990, xxxi). In Michel de Certeau's analysis, writing to Léry is an instrument with the power to both retain the past and conquer distance, whereas speech can neither preserve nor travel from its place of production (Certeau 1988, 216). When Léry hears a Tupi myth that resembles the Deluge, he attributes its different ending to the fact that "being altogether deprived of writing, it is hard for them to retain things in their purity" (Léry 1990, 144). In matters of religious belief, he accepts only Scripture as truth, but when it comes to the natural world, we shall see that Léry is willing to take the Tupinamba's word.

Léry learned the language of the Tupinamba and incorporated some of their words into his text. Histoire d'un voyage is one of the early texts containing written forms of Tupi words. Now known as Ancient Tupi, called the Lingua Brasilica in the sixteenth century, the language was spoken all along the Brazilian coastline. It was learned by the Portuguese colonists; in fact, for several centuries it was the main language spoken in Brazil, until the Portuguese government decreed in 1758 that Portuguese was to be the national language. Starting around 1548, religious texts were translated from Portuguese into Tupi. The first Tupi grammar was compiled in 1555 by Jesuit missionary José de Anchieta, but not published until 1595 (Navarro 2001, 51-57). Contact between the French and Tupi languages dated back to the early sixteenth century: French truchements or interpreters had been living among 
the Indians, learning the language and serving as liaison agents to the French colonists and missionaries. One chapter of Histoire d'un voyage, which may not have been written entirely by Léry, is a colloquy in Tupi with French translation. It provides vocabulary related to trade and barter, social customs, body parts, household items, and place names, and discusses some of the features of the Tupi language.

\section{"Foreignization" in travel and ethnographic texts}

In Across the Lines: Travel, Language, Translation, Michael Cronin suggests that the travel writer can adopt one of two strategies: heteronymous translation, in which the traveller avoids direct contact with the inhabitants of the foreign country and depends on an interpreter for communication, and autonomous translation, in which the traveller learns the language and engages directly with the local people (Cronin 2000, 76). Similarly, the travel writer may opt for a strategy of domesticating (privileging fluency and couching the foreign in terms generally familiar to readers) or foreignizing (leaving foreign words or concepts in the text, making visible the communication processes with the inhabitants of the foreign land), to use terms developed by Lawrence Venuti that have been widely taken up in translation studies and can be extended to travel writing (Polezzi 2001, 83; Venuti 1994, 20-23).

Jean de Léry, who lived among the Tupinamba and was dependent on them during the months he and his party spent on the mainland, incorporated their language liberally into his text. If we consider Chapters IX to XIII, the chapters that deal with the flora and fauna of Brazil, Léry has included 116 words in Tupi in the space of forty-three pages, an average of nearly three new foreign words per page. We can consider that he employs a strategy of foreignization.

Léry's transcription of oral terms into written form is marked by a simple but powerful technique. Of the 116 Tupinamba words in the chapters on Brazilian flora and fauna, nearly three-quarters are directly preceded by words such as "qu'ils nomment," "que les sauvages appellent," or "laquelle en leur langage ils appellent." This technique is maintained in 
Janet Whatley's translation in almost every instance, through words such as "which they call," "which the savages call," and "which they call in their language."

Léry's technique must be seen as a deliberate choice, for it is not the only way to present foreign words in an ethnographic text. For example, in Tristes Tropiques, describing the twentieth-century world of descendents of those same Tupi Indians, Lévi-Strauss simply italicizes the foreign words, sometimes adding a translation in brackets — "marshes full of sapézals (tall grasses) and buritizals (palm trees)" — and occasionally using an impersonal form — "which are called" (Lévi-Strauss 1963, 314). Or if we consider Léry's rival André Thevet in La Cosmograpbie universelle, he does sometimes use "qu'ils nomment" or "qui s'appellent en langue sauvage," but at other times he simply mentions the animal ("As for Hutiaqua, it is the size of a small pig ... [our translation]"). At times, he refers to unfamiliar animals by the names of similar European or Asian species: he uses the word once (a central Asian panther also known as the snow leopard) for what Léry calls a jaguar, the Tupi word for this wildcat found only in South and Central America, and he calls poulles d'Inde the birds for which Léry uses the Tupi word jacous (Thevet 1953, 156-158).

I suggest that Léry's technique, used repeatedly, amounts to giving the Tupinamba a voice: they name things in their language, and he records those names in his text. Names of plant and animal species do not simply exist but have been actively given to them by the Tupinamba. Léry has relinquished some degree of authority over the text and acknowledged their authority over their own world, the natural environment that they knew so well and that was so utterly unlike the world of the French missionaries. Following Bahktin, James Clifford suggests that certain ethnographic texts contain traces of "dialogic" and "polyphonic" authority, calling into question the monophonic authority of those who claim to "represent cultures." In traditional ethnography, one voice was given the authorial function while others were recognized only as sources or "informants." In what Clifford calls a "dialogical portrayal," other voices are present, although they may still be unequally weighted. Such a text does go some way towards resisting "the pull 
toward authoritative representation of the other" (Clifford 1986, 15; Clifford 1983, 137-140; Polezzi 2001, 103).

One of the aims of revisiting the literature of discovery and exploration of the sixteenth century is to seek out traces of alternative voices from the past, voices that do not conform to the ideology of the colonialist project. Here we have a case in which such traces are present, in the collective voice of the Tupinamba. We can conceive of Histoire d'un voyage as already containing translation, to the extent that transposing from oral to written form is a kind of translation, or rewriting as André Lefevere has described it: an "original," in this case an utterance, is manipulated according to the constraints of another system of communication, producing "refractions" that extend its lifespan and give it meaning in new contexts (Lefevere 1992, 8-9; Polezzi 2001, 88, 108-109). Léry maintains the names of species in their original language, "translating" from speech to writing, but not translating the Tupi names or replacing them with European equivalents. In turn, Janet Whatley maintains the Tupi words in the English translation: despite the distance of time and the movement through two languages, the collective voice comes through intact.

\section{Naming the New World}

In consultation with specialists on Brazilian flora and fauna, Janet Whatley has identified virtually every item Léry mentions. He categorizes plants and animals according to an informal system based roughly on Pliny's Natural History, devoting a chapter each to foodstuffs, animals, birds, fish, and trees. He follows the classic sixteenth-century taxonomies of living creatures, such as Pierre Belon's Histoire de la nature des Oyseayx (1555). As was usual at the time, he includes whales as fish (things that live in the water) and bees and bats in the chapter on birds (things that fly). His primary concern was with the use humans can make of each item, as food, ornamentation, or shelter - a focus on utility which, again, was common in the sixteenth century. Remember that at the time, scientist and common man alike believed that every living 
being was created by God in its current form and was incapable of changing; all animals, even the different species on the unconnected land mass of the Americas, were created in the Garden of Eden. Although the explorers immediately observed that New World flora and fauna, especially those of the Caribbean and South America, were distinct from that of Europe, the concept of endemism - that plants and animals are exclusive to certain geographical areas — had not yet been developed.

The two basic naming strategies in the New World were borrowing and semantic shift (Tuttle 1976). Borrowing involved adopting a word from an indigenous language, whereas semantic shift meant taking a term from the colonizer's language and adapting it to the new environment, drawing analogies with the familiar environment. Columbus first used the term panizo, Spanish for "panic grass," for corn (Zea mays), before adopting the term maize from Arawak, the language of the Tainos on the island of Hispaniola, the people with whom he first made contact. Other early borrowings from Arawak into Spanish include aje (sweet potato), yucca (cassava or manioc), manati (manatee or sea-cow), iguana and buracán (hurricane).

As a result of contact between French travellers — including Léry and his party - and the Tupinamba of coastal Brazil, a number of Tupi words entered the French language starting in the sixteenth century, particularly to name plants and animals unknown on the European continent. These include ananas (pineapple), manioc, jaguar, sagouin (a South American monkey), caiman (an alligator-like reptile), agouti (a rodent related to the guinea pig), tapir (a nocturnal hoofed mammal), toucan (a brightly coloured tropical bird), coati (a raccoon-like carnivorous mammal), and acajou (the cashew tree and its fruit). Ancient Tupi had even more influence on Brazilian Portuguese: it is estimated that nearly ten thousand Tupi words are found in Brazilian Portuguese, and some scholars believe Tupi has also affected its syntax and phonology (Navarro 2001, 53-55).

It is important to acknowledge these borrowings from indigenous languages, for in many cases they are all that is left of those languages. 
By the mid-sixteenth century, only decades after Columbus's arrival in the New World, the Tainos had been virtually wiped out by war, slave labour, and epidemics. The people and their language are today extinct. Classical Náhuatl and Quechua, the languages of the Aztecs and Incas and the source of many Spanish words such as tomate, chocolate, and coyotè, are considered extinct today, although variants have survived. Algonquin, the source of many English borrowings such as persimmon, chipmunk, raccoon, and toboggan, is considered nearly extinct ${ }_{i}$ Huron, the language spoken by French Canadian truchements, became extinct in the mid-nineteenth century. And Ancient Tupi, a branch of the TupiGuarani family of languages, is now extinct, as are the Tupinamba themselves, so vibrantly portrayed in Léry's text.

Janet Whatley's translation of Histoire d'un voyage thus revives the collective voice of an extinct indigenous people in a text that gives them a degree of authority. She has given English-speaking readers access to a classic text of the discovery and exploration of the New World that previously had only been available in a partial translation and in the context of English colonization. Her highly readable, modernized rendering makes the text available to a wide audience. At the same time, with her extensive annotations, she has positioned it in the context of recent scholarship on first contact with the New World.

CHRISTINE YORK

Concordia University

(Canada)

\section{Notes}

1. Whatley, "Editions and Reception of Léry," in Léry (1990, 223-224), and e-mail correspondence, March 22, 2004.

2. Janet Whatley discusses the issue of who composed the colloquy (Léry 1990, 253). Whether written wholly or partially by Léry, by Villegagnon as André Thevet claimed, or with the assistance of truchements, the colloquy is a valuable record of the Tupi language in the sixteenth century. 


\section{References}

Primary sources

Léry, Jean de. (1578). Histoire d'un voyage faict en la terre du Brésil autrement dite Amerique / le tout recueilli sur les lieux par Jean de Léry. Geneva, Pour Antoine Chuppin.

. (1975). Histoire d'un voyage fait en la terre du Brésil, ed., pres. and notes by Jean-Claude Morisot. Index of ethnological notions by Louis Necker. Facsimile of the 1580 edition, which was the basis for Whatley's translation. Geneva: Droz.

(1990). History of a Voyage to the Land of Brazil, trans. Janet Whatley. Berkeley: University of California Press.

\section{Secondary sources}

Céard, Jean. (1971). Introduction to Des monstres et prodiges, by Ambroise Paré. Geneva: Droz.

Certeau, Michel de. (1988). "Ethno-Graphy: Speech, or the Space of the Other: Jean de Léry." In The Writing of History, trans. Tom Conley. New York: Columbia University Press.

Clifford, James. (1983). "On Ethnographic Authority." Representations 2, 118-146.

- (1986). Introduction to Writing Culture: The Poetics and Politics of Ethnography, ed. James Clifford and George E. Marcus. Berkeley: University of California Press.

Cronin, Michael. (2000). Across the Lines: Travel, Language, Translation. Cork, Ireland: Cork University Press.

Gagnon, François-Marc. (1984). Jacques Cartier et la découverte du Nouveau Monde. Québec: Musée du Québec.

Greenblatt, Stephen. (1991). Marvelous Possessions: The Wonder of the New World. Chicago: University of Chicago Press.

Lefevere, André. (1992). Translation, Rewriting, and the Manipulation of Literary Fame. London and New York: Routledge.

Lestringant, Frank. (1991). "The Philosopher's Breviary: Jean de Léry in the Enlightenment," trans. Katherine Streip. Representations, 33, 200-211.

- (1996). L'Expérience buguenote au nouveau monde (XVIe siècle). Geneva: Librairie Droz.

Lévi-Strauss, Claude. (1963). Tristes Tropiques. Trans. John Russell. New York: Atheneum.

Mackenzie, Louisa. (2001). "Jean de Léry and the Sixteenth-Century French Encounter with American Nature." Paper presented at the 43rd annual conference of the Midwest Modern Language Association, Cleveland. 
Mandeville, Sir John. [1499]. (1900). The Travels of Sir Jobn Mandeville. Reprint, London: Macmillan.

Navarro, Eduardo de Almeida. (2001). "The Translation of the First Texts to Tupi, the Classical Indian Language in Brazil," trans. John Milton. In Emerging Views on Translation History in Brazil. São Paulo, Brazil: Humanitas FFLCH/ USP, 51-74.

Ong, Walter. (1982). Orality and Literacy: The Tecbnologizing of the Word. London: Methuen.

Paré, Ambroise. (1579). [1971]. Des monstres et prodiges, ed. Jean Céard. Reprint, Geneva: Droz.

Polezzi, Loredana. (2001). Translating Travel: Contemporary Italian Travel Writing in English Translation. Aldershot, England: Ashgate.

Purchas, Samuel. (1625) [1965]. Hakluytus Postbumus: or, Purchas His Pilgrimes: Contayning a History of the World in Sea Voyages and Lande Travells by Englishmen and Others. Vol. XVI, Ch. III, 518-579. Reprint, New York: Ams Press.

Senior, Nancy. (2004). "Of Whales and Savages. Reflections on Translating Louis Nicolas' Histoire naturelle des Indes occidentales." META, 49:3, 462-474.

Thevet, André. (1953). Les Français en Amérique pendant la deuxième moitié du XVI siècle: Le Brésil et les Brésiliens, ed. Suzanne Lussagnet. Paris: Presses Universitaires de France. (Contains La cosmographie universelle, 1575.)

Tuttle, Edward F. (1976). "Borrowing Versus Semantic Shift: New World Nomenclature in European Languages." In First Images of America: The Impact of the New World on the Old, ed. Fredi Chiappelli, 595-611. Berkeley: University of California Press.

Venuti, Lawrence. (1994). The Translator's Invisibility. London and New York: Routledge.

Whatley, Janet, trans. (1990). Introduction and notes to History of a Voyage to the Land of Brazil, by Jean de Léry. Berkeley: University of California Press. 
This page intentionally left blank 


\section{Amadis of Gaul (1803) and Chronicle of the Cid (1808) by Robert Southey The Medieval History of Spain Translated}

\section{Introduction}

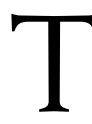

his article will deal with a "past translator," Robert Southey (1774-1843), and two of his "past translations," Amadis of Gaul (1803) and Chronicle of the Cid (1808), and will place its findings and proposals within the context of a combined double interest in translation and the future of history.

The historical figure of Robert Southey, as writer, historian, translator and human being, cannot be studied apart from the legendary fates of those British romantic aristocratic travellers who began including Spain and Portugal in their Grand Tour itineraries from the last decades of the eighteenth century. Before the Anglo-Italian Giuseppe Baretti, encouraged by Samuel Johnson, made up his mind to visit the region from 1770 and wrote a diary that aroused a surprising interest among readers, the Peninsula had been kept as a no-go territory due to its alleged lack of cultural interest and its sure dangers (García-Romeral 2000, 11-13). However, once the door had been opened, the number of travellers and the quality of their literary and/or historical output were 
epoch-making and have been regarded as a unique treasure for travel lovers and historians (Mitchell 1988, 7-8). This enthusiasm for Spain and Portugal among British romantics (Buceta 1923,1-25) includes eighteenth- and early nineteenth-century names such as Beckford, Carter, Clarke, Dalrymple, James, Jardine, Townsend, Swinburne, Twiss, Young, Murphy, and indeed Southey, for whom the impact of Iberia lasted the rest of his long life. But the trend continued up to the end of the twentieth century.

The characteristics of Southey's travel make it a very special case. First, he was neither a wealthy nor an aristocratic heir, but a poor young man, 21 years old, full of revolutionary social and political ideals. He came invited by his uncle, the Reverend Herbert Hill, who served the religious needs of the British colony at Lisbon. Secondly, he can be described as an individual endowed with an extraordinary gift for languages - one that allowed him to master both Spanish and Portuguese very quickly - and a soul with an unconquerable love for literature and history books and learning in general. This would eventually transform him into the first modern pioneer and vindicator of the literature of the Peninsula in the British Isles. Thirdly, he was a traveller who translated. He was a scholar who translated abundantly from Spanish into English as proved by both Amadis of Gaul and Chronicle of the Cid. In this regard, Lewis Spence, a renowned British scholar specializing in medieval Spanish heroic legends and books of knighthood, wrote: "Since the days of Southey the romantic literature of Spain has not received from English writers and critics the amount of study and attention it undoubtedly deserves" (1995 [1920], 5).

\section{About Robert Southey and his translations}

We will deal with Robert Southey and his translations through an approach characterized by a clear focus on the buman factor in translation and a well defined end, namely to construct a bistory of translation based on a bistory of translators. We will therefore ground our discussions and analysis on Pym's (1998) and Delisle and Woodworth's (1995) models. 
As will be revealed in this article, everything about the talents of Robert Southey points to history. He was not only a historian by vocation who devoted thousands of pages to historical research, but an unavoidable figure in the history of English-Spanish translation. Consequently, we strongly believe that he deserves to be included in a history of translation based on the guidelines mentioned by Pym (1998, ix-xi).

\section{a. Causation}

As already mentioned, Robert Southey was one of those legendary English romantic travellers who wandered around the Iberian Peninsula (See Alberich 1981, Buceta 1923, Burns 1988, Freixa 1993, García-Romeral 2000, García Mercadal 1999, Guerrero 1990, Locker 1998, Mitchell 1988, Robertson 1976). He visited Spain and Portugal during two different short periods: 1795-1796 and 1800-1801 respectively (see Martínez Barbeito 1972-73, 169-196); but brief as the total amount of time may have been, it was more than enough for him to become an expert lover of Spain, Portugal, and Latin America; of their languages, Spanish and Portuguese, and of their cultures and literatures, one of the main subject matters of his life and his vast literary and research careers.

\section{b. The translator and bis social entourage}

Southey was a most devoted man of letters and a professional writer who led a life of continuous work. He was a biographer, poet, translator, essayist, scholar, researcher, and prose writer. His only patrons (or clients) were his readers. He can also be described as a devoted family man who brought up his children in the rural Lake District of England, where they all learned to enjoy life peacefully. All these people were involved in his career as a professional translator because most of his translations, like most of his many other texts, were done for very pragmatic ends: to please his readers/customers in order to earn his wages and to raise and feed his family. 


\section{c. The target culture}

Southey became the main interpreter of Spain and Portugal for nineteenth-century British audiences - his target culture - who developed a great national interest in the things of the Iberian peninsula, unexpectedly aroused by the glorious Peninsular War against Napoleon at the beginning of the century. His translation Chronicle of the Cid (1808) was mainly produced to meet this interest (Buceta 1922, 52-57). He could provide what his target culture demanded.

\section{d. The present}

There is no doubt that what translators did in the past and what their translations were like are the best examples that today's translators and translation researchers can turn to for help and guidance. This is what the most traditional mission of History, History of translation included, is supposed to be about. From that point of view, Southey is still of great interest for the present. He set an enduring example.

\section{e. Robert Southey's views on translation}

Southey was not only a devoted translator but an individual who used to read incessantly. Consequently, it can no doubt be claimed that he had to be aware of past and current theories or reflections on translation. For example, he most probably read and gave some thought to John Dryden's Preface to his popular translation of Ovid's Epistles (1680), where he proposed his simplified classification of translation into three main categories: 1 . Metaphrase or "Word by word and line by line" translation (literal translation); 2. Paraphrase or "Translation with latitude," that is, when words are not so strictly followed as their sense (faithful or sense-for-sense translation); and 3. Imitation or "Forsaking both words and sense" (very free translation, more or less adaptation). As is very well known, Dryden, who gave new life to very old concepts, discouraged the first and the third, and prescribed the second, the via media. He was a man of the Enlightenment. 
Southey most probably also read and pondered over the Essay of the principles of translation $(1790,1791)$ by his contemporary Alexander Fraser Tytler, who published it only a few years before our Bristol intellectual started producing his own long translated volumes. Tytler avoids the traditional dichotomy between literal and free translation and also defines a "good translation" in TL-reader-oriented terms. A good translation is one in which the merit of the original work is so completely transfused into another language as to be as distinctly apprehended, and as strongly felt, by a native of the country to which that language belongs as it is by those who speak the language of the original work. For this purpose, he also proposed his own three general laws of translation:

1. The translation should give a complete transcript of the ideas of the original work ${ }_{i} 2$. The style and manner of the writing should be of the same character as that of the original; and 3 . The translation should have all the ease of the original composition.

In case of conflict among these laws, ease of composition (3) should be sacrificed if necessary for manner (2), and a departure would be made from manner in the interest of sense (1). Fidelity to the content comes first. Form comes second. And search for naturalness in the target language closes the circle.

Southey obviously could not have read The Translator's Invisibility, where Venuti $(1995,65)$ not only claims that "invisibility" has always been dominant in Anglo-American translation practice but also emphasizes that "In DRYDEN's wake, from ALEXANDER POPE's to ALEXANDER TYTLER's systematic Essay on the Principles of Translation (1791), domestication dominated the theory and practice of English-language translation in every genre, prose as well as poetry." What about Robert Southey's medievalizing translations of Spanish medieval texts? Venuti only mentions him briefly. Southey not only rejected the theory he inherited (Dryden or Tytler), but produced something new that anticipated what some Victorians would do decades later and some contemporary 
translation studies scholars would promote many years later. This is the importance of being Southey.

Frequently, ideas on translation must be found hidden in prologues, letters, essays, notes, dictionaries, speeches, and so on. Specific treatises on translation have been very rare until contemporary times (Lafarga 1996, 16). Southey's thinking on translation can only be found dispersed in a good number of items belonging to his vast bibliography. There is no coherent long piece of writing of his but many small-range textual instances instead. For example, in his Omniana, or Horae Otiosiores (1812), the following two paragraphs can be read:

6. TRANSLATIONS. It has been well said, that to translate a book is like pouring honey from one vessel into another . . . something must always be lost. Both the Dutch and the French words for "translated," will bear to be literally rendered, overgezet, and traduit. Milton may more truly be said to be overset in one language and traduced in the other, than translated into either. Done into English was not so happy a phrase, for many a book was undone by the operation (Southey 1969, 37).

218. MISTRANSLATIONS. A curious collection might be made of the mistranslations in our language, not those which have grown out of an idiomatic expression, like La dernière chemise de l'amour, for love's last shift, but those which have proceeded from the ignorance of the translator. Thevenot in his Travels speaks of the fables of Damné et Calilve, meaning the Heetopades, or Pilpay's fables. The translator, however, calls them the fables of damned Calilve. In the compilation from the Mercurio Peruano, which was published some years ago, under the title The Present State of Peru, P. Geronymo Roman de la Higuera, a name well known in Spanish literature, is translated, Father Geronymo, a Romance of La Higuera (Southey 1969, 150).

His numerous letters are also an excellent source of reflection on translation, as the following examples prove: 
To the Messrs. Longman and Co.

June 29, 1807.

Dear Sirs,

I have been told by persons most capable of judging, that the old translation of Don Quixote is very beautiful. The book has never fallen in my way. If it be well translated, the language of Elizabeth's reign must needs accord better with the style of Cervantes than more modern English would do; and I should think it very probable that it would be better to correct this, than to translate the work anew. As for my undertaking any translation, or indeed any revision, which might lead to the labour, of half the labour, which Palmerin cost me, it is out of question, but if Mr. Heber can lend you this translation; I will give you my opinion upon it: and I will do for you, if you want it, what you would find much difficulty in getting done by any other person (Southey 1849, 104-105).

To Grosvenor C. Bedford, Esq. April 13, 1805.

Dear Grosvenor,

There is a translation of Sallust by Gordon. I have never seen it, but having read his Tacitus, do not think it likely that any new version would surpass his, for he was a man of great powers. It is not likely that Longus Homo, or any other Homo would pay for such a translation, - because the speculation is not promising, every person who wishes to read Sallust, being able to read the original. There are some Greek authors which we want in English, Diodorus Siculus in particular (Southey 1849, 327).

His references to the old history of translation also abound: "St Jerome is said to have translated the Old and New Testament into the Illyrian (or Slavonic) language, his native tongue. And this version was still used in the church when Dubrarius wrote" (Southey 1850, 120-121); but an avoidable text in this regard is his Preface to Amadis of Gaule (Lobeira $1872 \mathrm{a} 2, \mathrm{v}-\mathrm{xxvi}$ ). This work by Southey is a translation of the original Spanish medieval classic Amadís de Gaula, a chivalric romance in prose 
and the major contribution in Spanish to medieval Arthurian literature. A primitive non-extant Amadís was composed about 1340, probably in Castile, by a single author who adapted Arthurian motifs and characters from French sources and produced a new original story. After a number of enlargements and modifications, Garci Rodríguez de Montalvo, a Castilian nobleman of whom little is known, restyled, frequently shortened, and also added new passages to his sources, and published the only version of the romance kept in 1508 (Lacy 1996, 326-327). This is the one that Southey knew and translated. The Bristol man of letters also adapted and shortened his source very much. Amadis was always very successful, not only in Spain but in many other European countries, thanks to the publication of many sixteenth-century translations of it into French, German, Dutch, Italian, English, and Hebrew. It is also the origin of a very productive genre: the so-called native Spanish and Portuguese Books of Knighthood, at length to be parodied ruthlessly and closed forever by Don Quixote. However, Cervantes saved the Amadís when all Don Quixote's Books of Knighthood were burned in order to deter future readers from its dangers.

The following general statements from the aforementioned Preface help us to enumerate characteristics of this monumental translation enterprise undertaken by Southey:

1. RATHER FREE THAN TOO LITERAL: "To have translated a closely printed folio would have been absurd" (xxxi).

2. CONDENSATION BUT NOT LOSS OF THE TREASURES OF THE ORIGINAL: "I have reduced it to about half its length, by abridging the words, not the story; by curtailing the dialogue, avoiding all recapitulations of the past action, consolidating many of those single blows which have no reference to armorial anatomy, and passing over the occasional moralizing of the author. There is no vanity in saying that this has improved the book, for what long work may not be improved by compression" (xxxi-xxxii). 
3. RESPECT FOR THE ORIGINAL BALANCE OF THE ORIGINAL TEXT ELEMENTS: "The minutest traits of manners have been preserved, and not an incident of the narrative omitted. I have merely reduced the picture, every part is preserved, and in the same proportions" (xxxii).

4. KEEPING THE ORIGINAL EPOCH STYLE WHERE IT IS REASON ABLE TO DO SO: "A modern style would have altered the character of the book; as far as was my power I have avoided that fault, not by intermixing obsolete words, but by rendering the original structure of sentences as literally as was convenient, and by rejecting modern phraseology and forms of period" (xxxiv).

5. SPECIAL CARE WHEN TRANSLATING THE NAMES OF THE CHARACTERS: "The names which have a meaning in the original have not been translated. I have used Beltenebras instead of the Beautiful Darkling or the Fair Forlorn; Florestan instead of Forester; El Patin instead of the Emperor Gosling; as we speak of Barbarrosa, not RedBeard, Bocanegra, not Black Muzzle; St. Peter, not Stone the Apostle" (xxxiv).

6. THE EXERCISE OF MODESTY AS THE IDEAL VIRTUE OF A GOOD TRANSLATOR: "It cannot be supposed that I have uniformly succeeded" (xxxv).

Points 4 and 5 follow a clear foreignizing strategy, whereas points 1, 2, and 3 support domestication, turning him into a kind of bridge between classical predecessors and some of those he was to precede. In other words, modernized medieval classics must display a combination of old and new flavours at the same time. This fact has sometimes been underlined by researchers: "The archaic flavour of the translation is an objection sometimes made to Southey's translations, but his attempt to give the impression of a work written in medieval times by archaizing the language is certainly defensible and a practice of many translators since Southey's day" (Curry 1975, 136). Finally, as maintained by descriptive translation studies, and more specifically product-oriented translation studies (Holmes and Toury), there is no translation practice without a conscious or 
unconscious, explicit or implicit theory of translation hidden behind it. For historical reasons, a full treatment of the theoretical challenges attached to translation activities cannot be demanded from Southey, but this does not mean that it cannot be deduced from his thousands of translated lines and paragraphs.

\section{The impressive wealth of Southey's \\ Hispanic and Portuguese collection}

Robert Southey is one of the most prolific writers in the English language. The complete corpus of his works is almost impossible to list, and many of them consist of hundreds of pages in prose and verse. $\mathrm{He}$ was also the proud owner of one of the biggest and most valuable private libraries of his times in the United Kingdom. His Hispanic and Portuguese collection, consisting of his own corpus among many other volumes, was also quite impressive and no doubt the most outstanding and complete Hispanic and Portuguese library of the period in the British Isles. ${ }^{1}$

Any list of examples drawn from his original work, in prose and in verse, can provide sound testimony to the above claim. The ancient history of the Spanish Goths and the Moorish invaders, for example, keeps company with glorious epic tales of the new American Vice-Royalties and its Conquistadores and Indian peoples. ${ }^{2}$

A chapter apart is that epitomized by his abundant verse translations from Portuguese and Spanish poets, and his three massive prose volumes from medieval and Renaissance classics: Amadis of Gaul (1803), Palmerin of England (1807) and Chronicle of the Cid (1808).

And finally, as noted above, there is his impressive library consisting of hundreds of books in Spanish and Portuguese patiently sought, bought, transported to England, and stored, studied, and read near the Lakes. It must also be observed that most of the titles and subject matters belonging to his aforementioned Hispanic and Portuguese Collection are related to history or historical characters. 


\section{Amadis of Gaul: A domesticating experience}

The following example and its corresponding translation, taken from both original and translated texts, illustrate what Southey wanted to do and did when dealing with The Amadis, insofar as his compression for improvement and medievalizing strategies appear in action. The middle text represents our own literal translation into English of the original Spanish excerpt.

\section{Capítulo VI}

Como el Donzel del Mar combatió con los peones del cavallero, que Galpano se llamava, y después con sus hermanos del señor del castillo y con el mesmo señor y lo mató sin dél haver piedad.

Pues llegando del Doncel del Mar cerca del castillo vio venir contra él una doncella haziendo muy gran duelo, y con ella un escudero y un doncel que la aguardavan. La doncella era muy hermosa y de hermosos cabellos, y ívalos messando. El Doncel del Mar le dixo:

- Amiga, ¿qué es la causa de tan gran cuita?

- Ay, señor — dixo ella — es tanto el mal que vos lo no puedo decir!

— Dezídmelo — dixo él — y si con derecho vos puedo remediar, fazerlo he.

— Señor — dixo ella - yo vengo con mandado de mi señor a un cavallero mançebo de los buenos que agora se saben, y tomáronme allí cuatro peones, y llevándome al castillo fue escarnida de un traidor, y sobre todo hízome jurar que no haya otro amigo en tanto que él biva (Rodríguez de Montalvo 1987a, 293).

\section{Chapter VI.}

How the young Knight of the Sea battled with the men of the knight, whose name was Galpano, and then with the brothers of the Lord of the castle and with the very Lord bimself, whom be killed taking no pity on bim. Since, when the young Knight of the Sea was approaching the castle, he saw a damsel coming towards him in great sorrow, and with her a squire and a page, who were taking care of her. The damsel was very beautiful and with 
beautiful hair, that she was tearing. The young Knight of the Sea asked her:

Friend, what is the source of your great grief?

Oh, sir — she said - the evil is so terrible that I cannot tell it!

Tell it to me - he said — and if I can honestly help you, I will do it.

Sir — she said - I come with a message from my Lord for a young knight, one of those good ones there are these days, and four men took me there and carried me to the castle where a traitor made fun of me, and, above all, made me swear not to have any other friend while he is alive [my translation].

Chap. VII. - Of the battle which the Child of the Sea bad with Galpano and bis people.

As the Child of the Sea approached the castle he met a damsel accompanied by a squire and page, she was a fair damsel, and her hair was beautiful which she rent as she went along, and made great lamentation. When the knight heard how she had suffered from the custom of that castle, he took his bridle and said, Come with me and I shall avenge you (Lobeira 1872a, 40).

The differences in length and structure between Southey's translation and the original are very marked. It cannot be denied that Southey followed his own rules very faithfully. He was not literal because such a naive medieval dialogue would (obviously) not have been appropriate for a modern audience. He used the strategy of condensation or compression, but without loss of the treasures of the original, which still seems or sounds very medieval, although it is not any more. There is also no omission of any main incident. All these facts point to "domestication," as has been claimed above. Besides, there is also some temporal "foreignization," suggesting a distant medieval setting by means of lexical units such as "damzel," "knight," "page," or "squire." Finally, Southey did not translate the foreign name Galpano, as he wrote that he was not going to in his Preface. 
The twentieth century knew some Spanish abridgements and adaptations of Amadis de Gaula, such as the one by Ángel Rosenblat, which was probably the most successful. Rosenblat supports very passionately the idea that this medieval work must be modernized for modern popular audiences to have again the opportunity to enjoy its many merits. He also claims that this had been the regular practice since the first nonextant fourteenth-century version of the Romance until the only one remaining, dating from the sixteenth century (Anonymous 1979, 13).

The following sets of parallel examples from Montalbo's, Southey's and Rosenblat's versions show how closely Southey's abridgements anticipated those to be made by Rosenblat many years later. They also prove how carefully the puritan Robert Southey proceeded to manipulate his original medieval source and to eliminate all sexual and/or erotic references. Curiously enough, many years later, Ángel Rosenblat did the same.

The text placed between Montalbo's and Southey's versions is my own literal translation of the Spanish original from the sixteenth century. I have also literally translated into English what Rosenblat did in the twentieth century:

\section{AMADÍS DE GAULA (Rodríguez de Montalbo 1508)}

Cómo la infanta Helisena y su donzella Darioleta fueron a la cámara donde el rey Perión estava.

Cuando la gente fue sossegada, Darioleta se levantó y tomó a Helisena assí desnuda como en su lecho estava, solamente la camisa y cubierta de un manto, y salieron ambas a la huerta, y el lunar hazía muy claro. La donzella miró a su señora, y abriéndole el manto, católe el cuerpo y dixo riendo: - Señora, en buena hora nasció el cavallero que vos esta noche avrá, y bien dezían que ésta era la más hermosa donzella de rostro y de cuerpo que entonces se sabía. Helisena se sonrió y dixo: - Assí lo podéis de mí dezir, que nascí en buena ventura en ser llegada a tal cavallero.

How princess Helisena and her maid Darioleta went to the chamber where king Perion was. 
When everybody was sleeping, Darioleta rose and called for Helisena naked as she was in her bed, with only her nightdress and a mantle over it, and they both went out into the garden, and the moonlight was very bright. The maid looked at her lady and drawing her mantle, felt her body and said laughing: How fortunate was born the knight that will have you tonight, and well they said that you were the most beautiful maiden ever known because of your face and body. Helisena smiled and said: - The same you can say of me, that I was born lucky to be with such a knight.

\section{AMADIS OF GAUL (Southey 1803)}

How Amadis was begotten and born.

At night when all was husht, Darioleta rose, and threw a mantle over her mistress, and they went into the garden. When Elisena came to the chamber door her whole body trembled, and her voice that she could not speak.

\section{AMADÍS DE GAULA (Rosenblat 1940)}

Cuando la gente de palacio dormía, Elisena y Darioleta salieron a la huerta. A Elisena le temblaba el cuerpo.

When everybody was sleeping in the palace, Elisena y Darioleta went to the garden. Elisena's body was trembling.

Southey did not omit as much as Rosenblat did, but nearly. However, the similarities show that the modernity and intuition of the former were very outstanding.

This second example displays that Southey could also domesticate his text, although not without guilt, as his gentleman/donzel footnote proves:

AMADIS OF GAUL (Southey 1803)

Then, said she, make this my Gentleman* knight; and she showed him to Perion; kneeling before the altar. The king saw him how fair he was, and approaching him, said, Would you receive the order of knighthood? - I would. — In the name of God, then! and may He 
order it that it be well bestowed on you, and that you may grow in honour as you have in person.

* An awkward word, but mi donzel cannot bere be rendered otberwise.

\section{Chronicle of the Cid: A blending experience}

Robert Southey can also be classified as a landmark in the bistory of History as a discipline. Almost everything is history in his pages, and after so many years of commitment to his studies, the Lake Poet became one of the most relevant and devoted scientific historians of English letters, as the following titles prove: History of Brasil (1810-1819), ${ }^{3}$ The Life of Nelson (1813), The Life of Wesley and the Rise and Progress of Methodism (1820), History of the Peninsular War (1823-1832) and Lives of the British Admirals (1833-1840).

But among all his works, there is nothing so intrinsically historical as his Chronicle of the Cid (1808): a unique blending of translation of a historical work and fiction based on historical facts. (See Chamosa 1987; Zarandona 1992-94). "Medieval history," a "historian" and "EnglishSpanish translation history" all together turn Chronicle of the Cid into a one-off opportunity to discuss the role of history in translation studies: the influence of the translator-historian, the manipulation-recreation of history, translation as a tool in the service of history/history as a tool in the service of translation, history and historiographic methods and translation approaches.

In other words, Chronicle of the Cid not only dealt with a key historical foreign figure and period but also constitutes a key example in the long history of translation between the English and Spanish languages and cultures.

Southey loved this work of his and his different sources without restraint, placing them on the level of Homeric epics and Shakespearean dramas. And this translation - his most reputed one - also enjoyed a very successful reception and made the national medieval historical hero of Spain very popular among contemporary English-speaking peoples, and was highly praised by Samuel Coleridge in 1808 . 
As the perfect translator-manipulator he always was, Southey stated in his Preface - another of his short texts reflecting on translation that Chronicle of the Cid was translated from three sources:

This Chronicle of the Cid is wholly translation, but it is not the translation of any single work. The three following have been used:

1. Crónica del famoso cavallero Cid Ruydiez Campeador. [Chronicle]

2. Poema del Cid. [Poem]

3. Romances del Cid. [Ballads]

Chronicle of the Cid is the main web of the present volume. . . I have incorporated with it whatever additional circumstances, either of fact or costume, are contained in the Crónica General or the Poema del Cid (Anonymous 1823, 177-183).

Unfortunately, the ballads, the poem, and his main source, the Crónica del famoso cavallero Cid Ruy Diez Campeador, published in Burgos, Spain, in 1593 , but closely indebted to medieval chronicles, are anonymous texts. ${ }^{4}$ Southey had this last book in his library. What he did was to add to the historical chronicle of the hero of Castile the literature of the epic poem of the Cid and the knight-warrior's popular ballads. The result was to be a unique hybrid consisting of, or originating in, three different genres.

And the mixture was a success. Thanks to the magical powers of translation, a wholly forgotten old chronicle text staged a comeback, becoming popular once more and reaching wide audiences and a huge readership in a different language and culture. Such emotional and dramatic passages as these two translated by Southey about the popular and noble hero of Castile make it easy to understand why:

My Cid Ruydiez entered Burgos, having sixty streamers in his company. And men and women went forth to see him, and the men of Burgos and the women of Burgos were at their windows, weeping, so great was their sorrow. (Anonymous 1823, 277).

When this was done the King bade the Cid make his demand; and the Cid rose and said, Sir, there is no reason for making long 
speeches here, which would detain the Cortes. I demand of the Infantes of Carrion, before you, two swords which I gave into their keeping $_{i}$ the one is Colada and the other Tizona. I won them like a man, and gave them to the keeping of the Infantes that they might honour my daughters with them, and serve you (Anonymous 1823, 411).

The first of the next two series of related examples, the one dealing with the legendary Jura de Santa Gadea — Swearing at Santa Gadea when The Cid made King Alphonsus swear three times against his will, shows how Southey departed from the original Crónica to take advantage of the much livelier tellings of popular ballads dealing with those momentous events.

The Swearing at Santa Gadea by Southey (Chronicle of the Cid 1808) gives a detailed account of the evolution of the King's feelings as the three oaths are demanded, from increasing fear to violent anger: "And the King's colour changed. . . . In the like manner the countenance of the King was changed again . . . but the wrath of the King was exceeding great." This brilliant gradation does not come from the Spanish Chronicle (Crónica particular del Cid 1593), where there is only the final wrath: ". . . pero fue ay muy sañudo el rey don Alfonso" [but King Alphonsus was very angry then]. The origin must be found in popular ballads, where there is the same triple combination of feelings: "Las palabras son tan fuertes / que al buen rey ponen espanto. . . Las juras eran tan fuertes / que el rey no las ha otorgado . . pero también dijo presto, / malamente y enojado" [The words are so strong / that the good king is scared. . . . The swearings were so strong / that the king has not consented to them ... but he also spoke quickly / rudely and angrily].

Now, this second series of examples proves how Southey privileged the dramatic Poem, rather than the dull Crónica, to write his own Chronicle. I have added my own literal translation of the excerpt from the Spanish Chronicle: 


\section{CHRONICLE OF THE CID}

(Southey, 1808)

Cortes de Toledo

When this was done the King bade the Cid make his demand, and the Cid rose and said, Sir, there is no reason for making long speeches here, which would detain the Cortes. I demand of the Infantes of Carrion, before you, two swords which I gave into their keeping, the one is Colada and the other Tizona. I won them like a man, and gave them to the keeping of the Infantes that they might honour my daughters with them, and serve you. When they left my daughters in the Oak-forest of Corpes they chose to have nothing to do with me, and renounced my love; let them therefore give me back the swords, seeing that they are no longer my sons-in-law.

\section{CRÓNICA PARTICULAR DEL CID (1593)}

Cortes de toledo

Se leuantó entonces el Cid y dixo: Señor razón luenga non hauemos por que dezir aquí ca sería gran detenimiento de la corte mas demando ante vos alos infantes de Carrión dos espadas que les empreste la una es Colada y la otra es Tizona. E pido voz Señor derecho que me las mandes dar que non han razón por que las tener contra mi voluntad.

The Cid rose and said: Sir I have sound motives to speak here in the Cortes for a long time, but I will claim in your presence of the princes of Carrión those two swords that I lent them, one is Colada and the other Tizona. I ask you, Sir, to command them to return them to me because there is no reason for them to have them against my will.

This original cannot be the only source for Southey's target text. Chronicle neither provides any information about the swords being won by the Cid like a man, nor about the Oak-forest of Corpes, where the Infantes dishonoured the Campeador's daughters, lost Mio Cid's love, chose not to have anything to do with him, and stopped being his sons- 
in-law. All these elements come from the Poem of the Cid (Cantar del Mio Cid), lines 2148-2158, where readers can find a much more dramatic retelling of the misfortunes of the Cid's daughters and the evils inflicted upon them by their mischievous husbands. Southey knew the Poem well. Again, this proves the originality, merit and sophistication of this translation by Southey and its three sources, which can be described as a "most unique blending experience."

As well, Southey provides some examples of his interest in medievalizing and foreignizing his text when he keeps the Spanish words Infantes and Cortes, instead of "Princes" or "Parliament."

\section{Conclusions}

There is no doubt that Robert Southey is a landmark in the bistory of world literature, being a leading member of the so-called Lake District Poets together with Samuel T. Coleridge and William Wordsworth. There is no doubt also that he is a landmark in the bistory of intercultural communication between the English-speaking and Spanish/ Portuguese communities because of his pioneering and brilliant translations, his travels and travel books and journals, and his contacts with prominent Iberian cultural institutions and individuals. (See Carnall 1971, Curry 1975, Madden 1972, Raimond 1968, Simmons 1945).

What Robert Southey and his Chronicle of the Cid prove, too, is that the translation of history can be regarded as a central area of study of the history of translation, giving rise to a challenging overlap of aims and methods. The translation of the humanities can also be deemed as rewarding as literary translation is for specialists in literary studies.

The human factor is a key factor in the history of translation as a whole and in the history of history in translation in particular. Southey sets a perfect example. The human factor - biography, interests, character can be equally detected in the "translation process," the "translation product," and the "translation function." The making of a general history of translators is a fascinating challenge for historians of translation.

Finally, Robert Southey, who loved, wrote and translated so many 
pages on Iberian and Latin American subject matter, could be regarded to a kind of patron or protector of such endeavours. Everything surrounding Southey is covered by a heavy curtain of neglect and oblivion nowadays. He deserves neither of them. ${ }^{5}$ Neither does a general history of translation.

\section{JUAN MIGUEL ZARANDONA Universidad de Valladolid} (Spain)

\section{Notes}

1. Unfortunately, the whole of the library of Robert Southey was sold in an auction soon after his death, the Hispanic and Portuguese section of it included. However, the auctioneers produced a full catalogue of all his books, which at least lets modern researchers have a precise idea of its scope and resources. This is what $\mathrm{H}$. Caskey also did when he published a complete listing of the Iberian collection (1943). The following volumes from this listing must be supposed to be the ones that Southey himself made use of to translate and write his Chronicle of the Cid:

3344. Crónica de la famoso cavallero Cid Ruy Diez Campeador. Burgos, 1593. [ . . . ]

3449. Romancero e Historia del Cid Ruy Diez de Bivar en Lenguaje Antiguo, recopilados por Juan de Escobar. [. . . ]

3719. Romancero General, en que se contienen todos los Romances que andan impresos. Medina del Campo 1602 (Caskey 1943, 91-155).

2. For a Monument at Tordesillas (1796)

For a Column at Truxillo (1796)

Letters Written During a Short Residence in Spain and Portugal (1797)

For the Cell of Honorius, at the Core Convent, near Cintra (1798)

The Spanish Armada (1798)

The Peruvian's Dirge over the Body of bis Father (1799)

Song of the Araucans (1799)

St. Juan Gualberto (1799)

Gonzalo Herminguez (1801)

La Caba (1802)

King Ramiro (1802)

Queen Orraca and the five Martyrs of Morocco (1802)

The History of Brazil (1810-1819) 
The Life of Nelson (1813)

Roderick, the Last of the Gotbs (1814)

History of the Peninsular War (1823-1832)

A Tale of Paraguay (1825)

The Pilgrim to Compostella (1829)

Journals of a Residence in Portugal 1800-1801 (1960)

3. Robert Southey's monumental History of Brazil was and is still a very much appreciated handbook, for consultation purposes, in this very Latin American Republic itself. It was also translated into Brazilian Portuguese in three volumes in 1977 (Southey 1977a, 1977b, 1977c).

4. The deeds of The Cid had been told before within different general chronicles, such as the one written during the times of King Alfonso X El Sabio (see Menéndez Pidal 1955), but later on new chronicles were published devoted only to the materials directly associated with El Campeador.

5. To honour his merits, Robert Southey was invited to join the restricted census of the Immortal, that is, the membership of the Spanish Royal Academy of Language. That he felt very happy about this flattering distinction is indicated by the inscription he used to include at the beginning of all his published works:

Robert Southey, Esq. LL.D.

Poet Laureate

Honorary Member of the Royal Spanish Academy,

of the Royal Spanish Academy of History,

of the Royal Institute of the Netherlands,

of the Cymmrodorion,

of the Massachusetts Historical Society.

\section{References \\ Primary sources}

Anonymous . (1593). Crónica de la famoso cavallero Cid Ruy Diez Campeador. Burgos. Anonymous. (1823). The Spanish Ballads and the Chronicle of the Cid, Rodrigo Díaz de Bivar, The Campeador, trans. J.G. Lockhart and Robert Southey. London: Frederick Warne and Co.

Anonymous. (1979). [1a 1940]. Amadís de Gaula. Novela de caballerías, modernizada y prologada por Ángel Rosenblat. Buenos Aires: Losada.

Anonymous. (1998). Cantar de Mío Cid. Introd. Alberto Montaner. Preface by Francisco Rico. Barcelona: Crítica.

Lobeira, Vasco. (1872a). Amadis of Gaul, trans. from the Spanish version of 
Garciordonez de Montalvo by Robert Southey. Vol. I. London: John Russell Smith.

(1872b). Amadis of Gaul, trans. from the Spanish version of Garciordonez de Montalvo by Robert Southey. Vol. II. London: John Russell Smith.

(1872c). Amadis of Gaul, trans. from the Spanish version of Garciordonez de Montalvo by Robert Southey. Vol. III. London: John Russell Smith.

Menéndez Pidal, Ramón, ed. (1955). Primera Crónica General de España que mandó componer Alfonso El Sabio y se continuaba bajo Sancho IV en 1289. Vol. II. Madrid: Universidad de Madrid, Facultad de Filosofía y Letras: Seminario Menéndez Pidal/Editorial Gredos.

Rodríguez de Montalvo, Garci. (1987a). Amadís de Gaula, ed. Juan Manuel Cacho Blecua. Vol. I. Madrid: Cátedra.

. (1987b). Amadís de Gaula, ed. Juan Manuel Cacho Blecua Vol. II. Madrid: Cátedra.

Southey, Robert. (1826a). Roderick, the Last of the Goths. Vol. I. London: Longman, Rees, Orme, Brown and Green.

. (1826b). Roderick, the Last of the Goths. Vol. II. London: Longman, Rees,

Orme, Brown and Green.

. (1849). Life and Correspondence, ed. Charles Cuthbert Southey. Vol. III. London: Longman, Brown, Green and Longmans.

. (1850). Common-Place Book. Second Series. Special Collections, ed. John Wood

Warter. London: Longman, Brown, Green, and Longmans.

. (1977a). História do Brasil, trans. Luís Joaquim de Oliveira e Castro. Vol.

I. São Paulo: Edições Melhoramentos.

. (1977b). História do Brasil, trans. Luís Joaquim de Oliveira e Castro. Vol.

II. São Paulo: Edições Melhoramentos.

- (1977c). História do Brasil. Vol. III. Trans. Luís Joaquim de Oliveira e

Castro. São Paulo: Edições Melhoramentos.

Southey, Robert and S. T. Coleridge. (1969). Omniana or Horae Otiosiores, ed.

Robert Gittings. Fontwell, Sussex: Centaur Press.

\section{Secondary sources}

Alberich, José. (1981). "En torno a los viajeros ingleses de la época romántica." In Imagen romántica de España: Introducción. Madrid: Ministerio de CulturaDirección General de Bellas Artes, Archivos y Bibliotecas, 29-36.

Buceta, Erasmo. (1922). "Opiniones de Southey y de Coleridge acerca del 'Poema del Cid."' In Revista de Filología Española, IX, 52-57. 
. (1923). "El entusiasmo por España en algunos románticos ingleses." In Revista de Filología Española, X, 1-25.

Burns, Tom. (1988). "La España que debe citarse." In Viajeros por España de Borrow a Hemingway, Madrid: Mondadori, 7-37.

Carnall, Geoffrey. (1971). Robert Southey. London: The British Council; Longman Group.

Caskey, H. (1943). "Catalogue of the Spanish and Portuguese Portion of the Library of Late Robert Southey, Esq., LL.D., Poet Laureate." In Revista do Instituto Histórico e Geográfico Brasileiro, 178, 91-155.

Chamosa, José Luis, and Trinidad Guzmán. (1987). "Robert Southey, traductor de poesía española." In Fidus Interpres. Actas de las Primeras Jornadas Nacionales de Historia de la Traducción. León: Universidad de León-Servicio de Publicaciones, 340-348.

Curry, Kenneth. (1975). Southey. London and Boston: Routledge and Kegan Paul.

Delisle, Jean, and Judith Woodsworth, eds. (1995). Les traducteurs dans l'bistoire. Ottawa: Les Presses de L'Université d'Ottawa / Éditions Unesco.

Freixa, Consol. (1993). Los ingleses y el arte de viajar. Una visión de las ciudades españolas en el siglo XVIII. Barcelona: Ediciones del Serbal.

García Mercadal, José. (1999). Viajes de extranjeros por España y Portugal. Desde los tiempos más remotos basta comienzos del siglo XX, pref. Agustín García Simón. Salamanca: Junta de Castilla y León-Consejería de Educación y Cultura.

García-Romeral Pérez, Carlos. (2000). Bio-Bibliografía de Viajeros por España y Portugal. Madrid: Ollero and Ramos Editores.

Guerrero, Ana Clara. (1990). Viajeros británicos en la España del siglo XVIII. Madrid: Aguilar.

Lacy, Norris J. (1996). The New Arthurian Encyclopedia. New York-London: Garland.

Lafarga, Francisco, ed. (1996). El discurso de la traducción en la bistoria: Antología bilingüe. Barcelona: EUB.

Locker, Edward H. (1998). Paisajes de España. Entre lo pintoresco y lo sublime, ed. Consol Freixa. Barcelona: Ediciones del Serbal.

Madden, Lionel, ed. (1972). Robert Southey: The Critical Heritage. London and Boston: Routledge and Kegan Paul.

Martínez-Barbeito, Carlos. (1972-1973). "Robert Southey desembarca en la Coruña." Revista del Instituto José Cornide, 8:9, 169-196.

Mitchell, David. (1988). Viajeros por España de Borrow a Hemingway, trans. Isabel Gómez-Arnau. Madrid: Mondadori.

Munday, Jeremy. (2001). Introducing Translation Studies: Theories and Applications. London and New York: Routledge.

Pym, Anthony. (1998). Method in Translation History. Manchester: St. Jerome. 
Raimond, Jean. (1968). Robert Southey: L'bomme et son temps, l'auvre, le rôle. Paris: Faculté des Lettres et Sciences Humaines-Librairie Marcel Didier.

Robertson, Ian. (1976). Los curiosos impertinentes. Viajeros ingleses por España. 1760-1855, trans. Francisco José Mayan, pref. Manuel Fraga Iribarne. Madrid: Editora Nacional.

Santoyo, Julio-César, and Isabel Verdaguer. (1987). De clásicos y traducciones. Clásicos españoles en versiones inglesas: los siglos XVI y XVII. Barcelona: PPU Promociones y Publicaciones Universitarias.

Simmons, Jack. (1945). Southey. London: Collins.

Spence, Lewis. 1995 [1920]. Spain. London: Senate.

Tytler, Alexander Fraser, Lord Woodhouselee. (1978). Essay on the Principles of Translation, intro. Jeffrey F. Huntsman. Amsterdam: John Benjamins.

Venuti, Lawrence. (1995). The Translator's Invisibility: A History of Translation. London: Routledge.

Zarandona, Juan Miguel. (1992-1994). "Robert Southey: Hispanista y traductor de obras clásicas castellanas medievales." In Revista de Investigación. Filología, XII: $1,7-27$.

. (2004). "The English Letters by Don Manuel Álvarez Espriella, PseudoTranslated by Robert Southey (1807)." Odisea, 5, 187-198. 


\section{Contributors}

\section{Sergia ADAMO}

Sergia Adamo teaches Comparative Literature and Literary Theory at the University of Trieste, Italy. Her research interests include intercultural relations, in particular translation history and travel writing. Among her publications are the volumes Dostoevskij in Italia (1998), Dislocazioni mediazioni migrazioni. Per uno sguardo interculturale alla letteratura (2003) and Ritratti di una citta'. Trieste tra scritti di viaggio e immagini retrospettive (2004). She is currently a Fulbright Visiting Scholar at Cornell Univeristy.

\section{Lourdes ARENCIBIA RODRIGUEZ}

Lourdes Arencibia Rodriguez is a professor, essayist, interpreter, and poet. She received her Master's degree in Economic Sciences and her Ph.D. at Havana University, and did postgraduate studies in International Economic Relations at the Institut d'Administration Publique of Paris. Currently Head of the Literary Translators Section in the Cuban 
Writers and Artists Association, she has written several studies on interpretation and translation theory and has been published in several countries. Arencibia Rodriguez is a regular lecturer in Latin American universities in Perú, Colombia, and México, as well as in Spain and the United States. She has translated Louis Aragon, Fabio Weintraub, Charles Baudelaire's poetry, and novels by French-speaking Caribbean writers such as Ernest Pépin and Daniel Maximin.

\section{Jesús BAIGORRI}

Jesús Baigorri holds a Master's degree in History and a Ph.D. in Translation and Interpreting from the University of Salamanca. A former staff interpreter at the United Nations in New York, at present he is responsible for the Interpreting Section at the Department of Translation and Interpretation of the University of Salamanca and continues to work as a freelance interpreter. He has published two books on the history of interpreting: La interpretación de conferencias: el nacimiento de una profesión: De París a Nuremberg, Comares, 2000 (De Paris à Nuremberg: Naissance de l'interprétation de conférence, traduit sous la direction de Clara Foz, PUO, 2004); and Interpreters at the United Nations: A History, translated by Anne Barr, Ediciones Universidad de Salamanca, 2004. He is a member of AIIC, AIETI and CATS.

\section{Paul BANDIA}

Paul F. Bandia holds a Master's degree in Translation and a Ph.D. in Linguistics from Université de Montréal, and is currently an Associate Professor in the French Department at Concordia University in Montreal. His research interests lie in the fields of discourse analysis, pragmatics, sociolinguistics, and intercultural communication, in relation to postcolonial studies and cultural history. He has published widely in the areas of translation theory and history, as well as in Francophone studies, literary linguistics, and cultural studies. For several years he was director of the Graduate Diploma in Translation program, and subsequently director of the Master's in Translation Studies program at Concordia University. He is currently working on issues of 
transnationalism and interculturality in the context of exile or migrant literatures, discourses and translation.

\section{Georges L. BASTIN}

Georges L. Bastin, Ph.D. in Translation Studies from the Université de Paris III, is Associate Professor in the Département de linguistique et de traduction at the Université de Montréal. He was previously Head of the Translation and Interpretation Department at the Universidad Central de Venezuela. His research interests lie in the fields of translation pedagogy and translation history. He is the author of iTraducir o adaptar? and two entries in the Routledge Encyclopaedia of Translation Studies, and has published in META, TTR, The Translator, La linguistique and other journals. He heads the Research Group on Translation History in Latin America (http://www.histal.umontreal.ca) and has edited two special issues of META (49:3 and 50:3) on translation history.

\section{Nitsa BEN-ARI}

Dr. Nitsa Ben-Ari is head of Diploma Studies for Translation and Revision in the School of Cultural Studies at Tel Aviv University. Her main field of study is translation norms, especially translation and ideology: manipulation, subversion and censorship. Her book Romance with the Past dealt with the role of the nineteenth-century German-Jewish historical novel and its translations in the emergence of a "New Hebrew" and a new national Hebrew literature. Her book Suppression of the Erotic is due to appear soon, from UOP and TAU Press. Ben-Ari is also an editor and translator. She has translated twenty-five books from English, French, German, and Italian.

\section{Jo-Anne ELDER}

Jo-Anne Elder holds a Ph.D. in Comparative Canadian Literature from the Université de Sherbrooke and has written on the translation and reception of literature as well as on women's culture. In her creative and community work, she works closely with New Brunswick's Acadian, First Nations, and Anglophone communities. The director of Ellipse 
magazine and the Side by Side Festival Côte à Côte, Jo-Anne has translated a dozen books in a number of genres (poetry, fiction, visual arts, film, history). Her translation of Françoise Enguehard's novel, Tales from Dog Island: St. Pierre \& Miquelon, was short-listed for the Governor General's Literary Award in 2003.

\section{Lydia FOSSA}

Lydia Fossa, Ph.D., is Professor of the Graduate Schools at the Catholic University and San Martín de Porres University in Lima, Peru. Her eight-chapter manuscript Los Inkas bajo la pluma española will soon be published by Instituto de Estudios Peruanos, Catholic University in Lima, Peru, and the University of Arizona. Also ready is her electronic version of the third part of the triptych Glosas Croniquenses: Glosarios tempranos Quecbua-Castellano. This Internet publication presents indigenous lexical items and their synchronic Spanish equivalents found in five early Andean chroniclers. Fossa's most recent publication is "Spanish in the Sixteenth Century: The Colonial Hispanization of Andean Indigenous Languages and Cultures," in Ideologies of Hispanism, ed. Mabel Moraña, Hispanic Issues No. 30, Vanderbilt University Press, 2005, 3-39.

\section{Clara FOZ}

Clara Foz is an Associate Professor of Translation and Translation Studies at the University of Ottawa. She is the President of the Canadian Association for Translation Studies, is a translator (member of OTTIAQ), and has published several translations (for example, of C. S. Peirce). Her research interests are in the History of Translation. Her book (1998) on the "Toledan Translators" Le traducteur, l'Église et le roi (University of Ottawa Press/Artois Presses Université) was translated into Spanish in 2000 as El traductor, la Iglesia y el rey (Gedisa Editorial, translated by Enrique Folch). She is now working on the French translations of Cervantes's Quijote (production and reception) from 1614 to 2001. 


\section{Marilyn GADDIS ROSE}

Marilyn Gaddis Rose, founding director of the translation program at the State University of New York at Binghamton, became aware of the relation of history and fiction in Malraux while following up on the data for her entry "Great Writers: Twentieth Century" in the Marshall Cavendish Encyclopedia. She is Distinguished Service Professor in Comparative Literature at Binghamton and is a recipient of the Alexander Gode medal of the American Translators Association.

\section{Chantal GAGNON}

Chantal Gagnon is a Ph.D. student at Aston University in the United Kingdom. She has published articles on revision, drama translation, and the translation of political speeches. She has taught at Concordia University, Open University, and Aston University. She is also the colist owner of Translatio, a mailing list for young and experienced scholars in translation studies.

\section{Claire-Hélène LAVIGNE}

Claire-Hélène Lavigne is Assistant Professor at the School of Translation and Interpretation, University of Ottawa. Her areas of research include the history of translation, the history of legal translation during the French Middle Ages and Renaissance, and legal translation and the theory of law. She has written various articles on the history of legal translation.

\section{Reine MEYLAERTS}

Reine Meylaerts is postdoctoral researcher of the Fund for Scientific Research Flanders at the Katholieke Universiteit Leuven (Belgium). She is doing research on intercultural relationships in multilingual societies, combining discourse analysis with analysis of translation strategies and of the (intercultural) actors' positions and position takings. She has published L'Aventure flamande de la Revue Belge. Langues, littératures et cultures dans l'entre-deux-guerres (PIE-Peter Lang, 2004) and is editor (with D. De Geest) of Littératures en Belgique-Literaturen in België. 
Diversités culturelles et dynamiques littéraires-Culturele diversiteit en literaire dynamiek (PIE-Peter Lang, 2004).

\section{Julio-César SANTOYO MEDIAVILLA}

Julio-César Santoyo Mediavilla studied at the Universities of Deusto, Zaragoza (Ph.D.) and London. Since 1981, he has been Full Professor of Translation Studies at the University of León (Spain), as well as ViceRector (1984-86) and Rector (1990-2000). He was Visiting Professor at the University of Massachussets (2000-01). He is the author of La cultura traducida (1983), El delito de traducir (1985), Ediciones y traducciones inglesas del Lazarillo de Tormes (1978), Historia de la Traducción: Quince apuntes (1999); Bibliografía española de la traducción (1996); and Teoría y crítica de la traducción: Antología (1987), among other publications. He has been the translator into Spanish of works by such writers as J. R. R. Tolkien, Oscar Wilde, E. A. Poe, Christopher Marlowe, Rudyard Kipling, Willa Cather, Flannery O'Connor, Robin Chapman, and Thomas Watts. His research interests in translation studies include history (ancient and medieval), bibliography, theory, reception, pseudo- and self-translations, and code-switching.

\section{James ST. ANDRÉ}

James St. André is Lecturer in Translation Studies with Mandarin at the University of Manchester, where he teaches courses on translation history, theory and practice, as well as courses on Chinese literature and culture. He has edited three volumes of writings by Singaporean Chinese writers, translated by students in the Department of Chinese Studies, NUS: Droplets, Yours Truly, and K.I.V. He has also published three translations of short fiction in te Chinese Pen (Taiwan). His recent articles on translation include "Revealing the Invisible: Heterolingualism in Three Generations of Singaporean Playwrights" in Target (forthcoming); "'But Do They Have A Notion of Justice?' Staunton's 1810 Translation of the Penal Code" in The Translator 10:1 (April 2004); and "Retranslation as Argument: Canon Formation, Professionalization, and Rivalry in 19th Century Sinological Translation" in Cadernos de Tradução 11.1 (2003). 


\section{Christine YORK}

Christine York is completing a Master's degree in Translation Studies at Concordia University. She holds a Bachelor of Fine Arts with a major in Art History from Concordia University. After working as a film researcher and production manager for ten years, she became a freelance translator specializing in audiovisual translation. Since 1994, she has translated or subtitled more than a hundred television programs, films, and scripts, including some twenty documentaries for the National Film Board of Canada.

\section{Juan Miguel ZARANDONA}

Dr. Zarandona is Associate Professor in the Faculty of Translation and Interpreting at the University of Valladolid at Soria. His research interests are in literary translation and history of translation in English and Spanish. His fields of study are Arthurian studies, African studies, and utopian studies and their relationships with translation: the history of Spanish Arthurian literature in translation, sub-Saharan literature in European languages translated into Spanish, and the translation of utopian newspeaks into Spanish. He is Editor of the Hermeneus Project of the University of Valladolid, consisting of three series: Hermeneus, a periodical on translation studies, Vertere, a collection of monographs on translation studies, and Disbabelia, a collection of unknown translations into Spanish. 


\section{Index}

Acuña Partal, Carmen, 122, 127

Adamo, Sergia, 4, 88, 97, 333-34

After Babel, 12, 87, 100, 139, 144; 12

Agorni, Mirella, 86, 97

Al-Harrasi, Abdulla Nasser Khalifa, 220

Al-Jâhiz, Abû Utmân, 27, 41

Alberich, José, 311, 331

Albir, Amparo Hurtado, 207, 222

Allison, Ann, 30, 197

Alvar, Manuel, 277, 287

Alvarez, Bartolomé, 286-87

Amparo Hurtado Albir, 222

Anderson, Benedict, 63, 76, 78

Andrade, Oswald de, 118, 127

Angoulvant, G., 176

Apollinaire, Guillaume, 190, 196

Appiah, Anthony, 51-52, 58

Appleby, Joyce, 92, 98

Arencibia, Lourdes, 8, 104, 110, 263-275, 333-34

Armony, Victor, 208, 210, 220-21

Arrojo, Rosemary, 205, 221

Badawi, Abdurrahmân, 27-28, 41

Baigorri-Jalón, Jesús, 4-5, 104-105, 109, 334

Baker, Mona., 53, 58

Baldinger, K., 280, 287

Ballard, Michel, 6, 12, 141, 143

Ballestero Izquierdo, Alberto, 34, 41

Balliu, Christian, 23, 41, 110

Bandia, Paul F., 45-58, 334

Bannet, Eva Tavor, 56, 58

Bassnett, Susan, 11-12, 41, 54-56, 58

Bastin, Georges L., 5, 104, 124, 127, 129, 335

Baudot, Georges, 266, 273

Baumgarten, Stefan, 206, 220

Becker, Stephen, 163, 167, 169, 175, 176

Bede, 14, 17

Ben-Ari, Nitsa, Dr., 7, 181, 197, 335

Benjamins, John, 23, 42, 43, 79, 98, 100

Benoiste, Françoise, 90, 98

Berman, Antoine, 12, 22-23, 41, 45, 58, 86-88

Bernal, Martin, 57, 58

Betanzos, Juan de, 286, 287, 289, 291

Biale, David, 181, 197

Bible: as an auctoritas, 159, Ecclesiasticus, translation of, 25-26; Gothic, translations of, 34; historical context, 52; "literalness topos" status, 147, New American Bible, 40; spirituality, efforts to retain, 236 ; translation, blank spaces, 39-40; translation, restrictive measures, 271 ; translations, varied, 13, 14

Blake, N. F., 29-30, 41

Bloch, Marc, 137, 143

Blodgett, E.D., 239, 240

Bourdieu, Pierre, 60-61, 76, 78, 134, 197

Bourque, Gilles, 201, 209, 220

Bowen, M., 104, 110
Boyd-Bowman, Peter, 280, 287

Boyden, Michael, 76, 78

Brewer Carías, A.R., 116, 127

Briceño Guerrero, José Manuel, 123, 127

Briceño Iragorry, Mario, 1, 9, 123, 127

Bringhurst, Robert, 7, 225-41

Brisset, Annie, 217-18, 220

Brown, Penelope, 214, 215, 220

Buceta, Erasmo, 310-12, 330, 331

Buckley, Sandra, 197

Bueno Chávez, Raúl, 287

Burns, Tom, 311, 331

Burton, Sir Richard Francis, 255, 260

Butler, Judith, 256, 260

Buzelin, H., 114, 127

Caillois, Roger, 20, 41

Calzada Pérez, María, 205-206, 220, 222

Campo, Ángela, 129

Canada, Prime Ministers of, 219-220

Carnall, Geoffrey, 327, 331

Cary, Edmond, 87, 98

Casanova, J. F. Ruiz, 34

Caskey, H., 328, 331

Castrillón, Elvia, 129

Céard, Jean, 298, 306

Cedulario del Perú siglos XVI, 273

Celi, Catarina, 240

Cerrón Palomino, Rodolfo, 280, 287

Certeau, Michel de: Ethno-Graphy: Speech, or the Space of the Other:, 306; form, content of, 94; historiography, writing of, 83, 296,300, L'Écriture de l'bistoire, 98; other, discourses on, 278

Chamosa, José Luis, 323, 331

Chang, Lesley-Ann, 18, 41

Charron, Marc, 204, 220

Chartier, Roger, 83, 98, 143

Chaunu, Pierre, 115, 127

Chesterman, Andrew, 205-208, 210, 218, 220-23

Chevalier, Haakon M., 163, 170-77

Chilton, Paul, 204, 216, 221

Cieza de León, Pedro, 274, 287

Claes, Ernest, 77

Clanchy, Michael, 17, 41

Clay [sic], John, 196

Cleland, John, 182, 189, 193, 196

Clifford, James, 302, 303, 306

Cline, Howard, 275

Cohen, Haim, 187, 197

Coleridge, Samuel Taylor, 323, 327, 330

Corbett, John, 95, 98

Corcuff, Philippe, 61, 78

Cormier, Monique C., 208, 221

Cornejo Polar, Antonio, 117-19, 126, 127, 277, 287

Corpus Iuris Civilis, 146-48

Courtès, J., 284, 288

Cowie, Moira, 23, 43 
Cristal, Efraín, 127, 129

Critical Discourse Analysis (CDA), 204-206, 209

Cronin, Michael, 4, 9, 86, 98, 301, 306

Curry, Kenneth, 317, 327, 331

Das, Sisir Kumar, 23, 41

Davis, Natalie Zemon, 90, 98

Davis, Sir John Francis, 247, 249, 259

Delisle, Jean: fields of research, 105, 109; La historia de la traducción, 110; historian, methods of, 103 history of translation, writing, 111-12, Interpreters as Diplomats, 13; Les interprètes français au Brésil au XVIe siècle, 110 , Les pionniers de l'interprétation au Canada, 110; Projet d'bistoire de la traduction au Canada, 110; Réflexions sur l'bistoriograpbie de la traduction, 109, 127; Repertoire of Historians of Translation, 109; Les traducteurs dans l'bistoire, 310, 331; La traduction raisonnée, manuel d'initiation à la traduction, 209, 221; Translation Terminology, 208, 221; Translators in History and Portraits of Translators, 134; Translators througb History, $88,94,98$

Dembowsky, Peter F., 150, 162

Derrida, Jacques, 55-56, 58

Descriptive Translation Studies (DTS), 59

D'hulst, Lieven: Cent ans de théorie française de la traduction, 88, 98; historiography of translation, 1, 4, 84, 112; Why and How to Write Translation Histories?, 9, 127

Diccionario de la lengua española, 287

Disbabelia, 339

D'Olwer, Luis Nicolau, 274

Duarte, Joâo Ferreira, 28-29, 41

Duchastel, Jules, 201, 208-210, 220, 221

Duviols, Pierre, 274, 288

Dworkin, Andrea, 192, 197

Echeverri, Álvaro, 129

Eco, Umberto, 143

Edwin Genzler, 199

Elder, Jo-Anne, 7, 240-41, 335-36

Ellis, Havelock, 192, 195, 196, 198

Enguita Utrilla, José M., 281, 287

Eshed, Eli, 186, 197

Eurocentric bias, 13, 50-55, 114-17, 269

Even-Zohar, Itamar, 197

Fairclough, Norman, 204-205, 221

Falcón, Francisco, 286, 287

Farge, Arlette, 93, 98

Feiner, Shmuel, 181, 198

Fernandez de Oviedo, Gonzalo, 274

Fitch, Brian T., 23, 41

Fokkema, Douwe, 60, 78

Fontana, J., 109

Forel, August, 192, 196

Fossa, Lydia, 8, 287, 288, 290, 336

Foucault, Michel: The Archaeology of Knowledge, 58, L'Archéologie du savoir, 98; archives, critical examination, 93; deconstructionist approach, 49-50, 82, 142, 296; Histoire de la sexualité, 192, 198 i Les mots et les choses, 143; Nietzsche, Genealogy, History, 58; The Order of Things, 58; power, exercise of, 49,57, La Vie des hommes infâmes, 93, 98

Foz, Clara, 31-32, 41, 110, 143, 336

Francisco, José, 12, 42, 99

Fraxi, Pisanus, 198

Freixa, Consol, 311, 331

Gaddis Rose, Marilyn, 163-177, 337

Gagnon, Chantal, 7, 204, 206, 218, 221, 337

Gagnon, François-Marc, 298, 306

Galante, Pierre, 177

Galich, Manuel, 274

Gandhl of the Qayahl Llaanas, 240

García Canclini, Nestor, 117, 119, 128

García Izcalbalceta, 273, 274

García Mercadal, José, 311, 331

García-Romeral Pérez, Carlos, 309, 311, 331

Garibay, Angel María, 274

Geldof, Koenraad, 60, 78

Gensini, Stefano, 89, 98

Gil, José S., 27, 41

Gilkin, Iwan, 66, 77

Ginzburg, Carlo: historian, role of, 91 ; Il formaggio e $i$ vermi, 98 ; Il nome e il come: scambio e mercato storiografico, 99; microhistory, 82, 95, 96, 97, 98; paradigm, conjectural, 90, 98; power relationships, 93

Glass, John G., 274

Glosas croniquenses, 8, 277-291

Godenzzi, Juan Carlos, 284, 288

Godin, Pierre, 216, 221

Goffman, Erving, 213, 221

Golan, Shmuel, 184-85, 197

González Holguín, Diego, 280, 288

González Palencia, Angel, 31, 41

Grases, Pedro, 116, 126, 128

Greenawalt, Kent, 182, 198

Greenblatt, Stephen, 180, 198, 296, 297, 306

Greimas, A. J., 284, 288

Grendi, Edoardo, 96, 99

Grifftih, Eric, 37

Gross, Alexander, 11-12

Grutman, Rainer, 25, 41

Guerrero, Ana Clara, 311, 331

Gutas, Dimitri, 32, 42

Guzmán, Trinidad, 331

habitus concept, 60-62

Haida Gwaii literature, 227-38

Hallowell, Gerald, 218, 221

Hanson, Ellis, 258, 260

Harper, Philip Brian, 256, 260

Haskins, Charles, 137, 143

Hatim, Basil, 204, 206, 221

Hermans, Theo, 42, 58, 59, 78

Historia a Debate website, 133-34

historiography: Aboriginal literature, 7, 225-38 Andean indigenous people, 277-86; Arabic translations, 15-16, 18, 26-28, 30-32, 51, 53; archives, 82, 92-93, 96, 106-107, 205; autobio- 
graphical writing, 94-95, 163; Chinese- English translation, 243-259; Critical Discourse Analysis (CDA), 204-206, 209; deconstruction paradigm, $3,47-50,55-56,82,142$; discursive practices, 49, 61-62, 64, 75, 86, 113; ethics in translation, 3, 54, 57,86 ; Eurocentric bias, 13, 50-55, 114-17, 269, 282, 296-98; feminist writings, 56, 194, 195, 256; geopolitical translations, 61-62, 64, 65, 71, 76; German theories, 22, 87-88, 123, 193, 228; Greek translations, 24-25, 27-30, 32, 34, 81, 89; historical role, 35-40, 82-84, 85-87, 90-91, 94, 132-36; indigenous terms, incorporating, 293-305; interventionist approach, 4, 48, 50-54, 57, 158; Latin American translations, $117-25$; legal texts, middle ages, 6, 145-158, 160; Malraux, André, 163-76; marginal translations, $49,81-82,87-88,92-93$, 187, 230; metalinguistic understanding, 84 ; methodology, translation, 45-48, 111-14, 120-25, 134-36; micro/macro textual studies, 61, 88-89, 165; microhistory, translation, 4, 81-98; mistakes, translation, 22, 27, 30-35, 156; modern theory of, $12,18,48,50,59,186$; novels, eighteenth century, 88 ; oral history records, 102-104; paleochristian literature, 29-30; periodization, 6, 82, 115, 120, $124,136-41$; political aspects, 56, 65; pornography, Hebrew, 179-95; post-structuralist theory, 56,82 ; postcolonial theory, 45, 47, 53, 56, 103, 108 ; postcultural theory, 56-57; postmodern trend, 51, 54-57, 133, 135, 205; preservation, 92, 103, 226, 228, 230-39, 231-38; racism, 5, 115, 124, 255; religious/political repositioning, 37, 263-64, 266, 268, 281; research fields, 105-107; Roman law, 164-48; Santa Cruz de Tlatelolco, 263-272; sociocultural positioning, 6, 63, 65-68, 71, 113, 117; sociopolitical repositioning, 35, 62-63, 66, 201-218; Southey, Robert, 309-328; texts, lost, 25-28, 226-27, 230, 278-79; textual/paratextual elements, 88-89, 122, 165, 205-207, 233; Toledo School of Translators, 31-35, 108, 263, 270; translations, prudish, 179-95; versified translation, 148-58, 180; Western theories, 38, 45, 88, 104, 125, 192

Hitchcock, Peter, 254, 255, 260

Holt, Thomas C., 255, 260

Holubnychy, Lydia, 176, 177

Holz, Arno, 22

Horguelin, Paul A., 26, 42

Hugonnard-Roche, Henri, 28, 42

Huizinga, Johan, 137, 143

Hunt, Lynn, 92, 98

Imperial College of Santa Cruz de Tlatelolco, 263-272

Íñigo-Mora, Isabel, 212, 221

Institutes, Justinian, 148-58, 161-62

Interpretatio (Rener), 12

interpretation, $13-15,47-48,108$

interpreters: conference, 108 ; European chanceries 14-15; Santa Cruz de Tlatelolco, 263-272;

Toledo, 31-35, 108, 263, 270, Xenophon's chronicle, 14

Itier, César, 281, 288
Itzkovitz, David, 255, 260

Jacob, Margaret, 98

Jacobs, Dan N., 176, 177

Jerome, Eusebius, 40

Joly, Jean-François, 22, 42

Josephus, Flavius, 24

Justinian, 146, 148-59, 161-62

Kahn, Fritz, Dr., 192, 196

Kálmán, G. C., 23, 42

Karttunen, Frances, 14

Kelly, Louis G., 12, 40

Kenis, Paul, 74, 77

Kervyn de Marcke ten Driessche, Roger, 69-74, 77

Kingsley, Charles, 256, 258, 261

Klinkenberg, Jean-Marie, 42

Klor de Alva, Jorge, 274

Koestler Arthur., MD, 196

Koran, 33

Koskinen, Kaisa, 55-56, 58

Krontiris, Tina, 99, 986

Kuhn, Thomas, 96, 99

Kurz, Ingrid, 104, 108, 110

Kuttner, S., 162

La Place, Pierre Antoine de, 97, 99

La politique coloniale et le Bolchévisme, 177

LaCapra, Dominick, 83, 91, 99

Lacouture, Jean, 177

Lacy, Norris J., 316, 331

Ladouceur, Louise, 218, 221

Lafarga, Francisco, 12, 314, 331

Lahire, Bernard, 61, 78

Lambert, José, 62, 78, 79, 83, 99, 218

Lander, Edgardo, 114, 125, 128

Laplantine, F., 114, 128

Lavergne, Gabriel Joseph de, 20

Lavigne, Claire-Hélène, 145-162, 337

Lawrence, D.H., 182, 189, 193, 196, 198

Le Goff, Jacques, 136-37, 144

Lee-Jahnke, Hannelore, 221

Lefevre, André, 11-12, 41, 54, 198, 303, 306

Lemarchard, Marie-José, 19, 42

León Portilla, Miguel, 129, 274

Lépinette, Brigitte, 43, 113, 128

Léry, Jean de, 9, 293-305, 306

Les 4 livres d'institutes du Justinian en vers, 161-62

Lesage, Alain-René, 97, 99

Lestringant, Frank, 294, 297, 306

Levi, Giovanni, 96, 99

Lévi-Strauss, Claude, 134, 295-96, 302, 306

Levinson, Stephen C., 220

Lewis, Bernard, 15-16, 42

Linguística Quecbua, 287

Ljudskanov, Alexandre, 6, 139, 144

Lobeira, Vasco, 315, 320, 329

Locker, Edward H., 311, 331

López Alcalá, Samuel, 113, 128

Lormian, Henri, 176, 177

Loth, David, 180, 182-83, 198

Luna, Rosa, 275 
Luykx, Theo, 79

Lyotard, Jean-François, 57, 58

MacDonald, Alastair, 164, 171, 173-77

Mackenzie, Louisa, 299, 306

Madden, Lionel, 327, 331

Maes, Pierre, 67, 77

Malraux, André, 6, 163-177

Mandeville, Sir John, 298, 307

Mari, Michele, 89, 99

Martínez-Barbeito, Carlos, 331

Matienzo, Juan de, 288, 290-91

Melyaerts, Reine, 4, 69, 76, 77, 337

Menéndez Pidal, Ramón, 329, 330

Merkle, Denise, 198

Meylaerts, Reine, 69, 78, 79, 337-38

Miller, Grady, 23, 42

Miller, Henry, 182, 189, 190, 193, 196

Milne, William, 249, 258, 259

Minnis, A. J., 162

Miron, Dan, 186, 196, 198

Mitchell, David, 310, 311, 331

Molina, Cristóbal, 206-207, 222, 274

Molina, Lucía, 206-207, 222

Montesquieu, Baron de, 20-21, 42

Morrison, Robert, 247, 249, 259

Mosse, George L., 184, 198

Mossop, Brian, 209, 222

Mounin, Georges, 12, 33, 87, 99

Muir, Edward, 85, 91, 96, 99

Multiconcord tool, 208

Munday, Jeremy, 331

Munslow, Alun, 46-47, 50, 55, 57-58

Nabokov, Vladimir, 182, 190, 197

Nadler, Steven, 30, 42

Navarro, Eduardo de Almeida, 300, 307

Niranjana, Tejaswini, 281, 288

Nouss, Alexis, 128

O'Malley, Patrick R., 256, 258, 261

Omer, Dan, 187, 197

Ondegardo, Polo, 287-91

Ong, Walter, 299, 307

Ortiz, Fernando, 118, 126, 128

Pagni, Andrea, 124, 127, 128

paleochristian literature, 29

Paré, Ambroise, 298, 306, 307

Payàs, Gertrudis, 127, 129

Peakman, Julie, 190, 198

Pereña, Luciano, 36, 42

Pizarro, Hernando, 286, 288, 290-91

Pizarro, Pedro, 286, 288

Platel, Mark, 79

Polezzi, Loredana, 301, 303, 307

Poni, Carlo, 96, 99

Pons, Anaclet, 97, 99

Popovic, Anton, 22, 42

Porras Barrenechea, Raúl, 273, 274

Potsdam Declaration, 37-38

Pratt, Mary Louise, 281, 288
Prost, Antoine, 136, 144

Purchas, Samuel, 296-97, 307

Pym, Anthony: Complaint Concerning the Lack of History in Translation, 83, 85, 99, 144; Interview with Anthony Pym, 128; On Method in Hispanic Translation History, 281, 288; Method in Translation History, 128 331; Negotiating the Frontier, 32, 42, 91, 135; translation history, 94-95, 112, 132, 134, 310-11

Quijano, Aníbal, 125, 127, 128

Raimond, Jean, 327, 332

Rajak, Tessa, 24, 29, 42

Rama, Angel, 115-17, 126, 128

Ramírez, José Fernando, 275

Rangel, Carlos, 114, 128

Réage, Pauline, 190, 197

Reid, Bill, 240

Rembar, Charles, 198

Rener, Frederick M., 12, 40

Reuben, David MD., 193, 197

Revel, Jacques, 96, 99

Ricoeur, Paul, 94, 99, 134

Rivarola, José Luis, 277, 288

Roberts, Geoffrey, 97, 99

Robertson, Ian, 311, 332

Robinson, Douglas, 26, 42, 88, 100

Robinson, Paul, 195, 198

Rodriguez, Lourdes Arencibia, 330

Rodríguez de Montalvo, Garci, 316, 319, 321, 330

Rodriguez Lafuente, Fernando, 272, 274

Roland, Ruth A., 13

Romano, David, 18, 42

Rorty, Richard, 82, 100

Rosenblat, Angel, 277, 289, 321, 322, 329

Rostworowski de Diez Canseco, Maria, 274

Rubinstein, Amnon, 198

Rubruc, William of, 16

Ruiz Casanova, José Francisco, 34, 42, 95, 100

Russell, Peter, 40, 306, 330

Sahagún, Fray Bernardino de, 8, 273, 274

Said, Edward, 53, 58

Salama-Carr, Myriam, 32, 43

Santa Cruz de Tlatelolco, 263-272

Santo Tomás, Domingo de, 280, 289

Santoyo, Julio-César, 15, 18-19, 43, 110, 144, 332

Santoyo Mediavilla, Julio-César, 338

Sarcevic, Suzanne, 145, 147, 158, 162

Saussure, Ferdinand de, 49, 258, 260

Scarborough, William, 249, 259

Schäffner, Christina, 206-207, 218, 221, 222

Schaub, Jean-Frédéric, 138, 143, 144

Schlaf, Johannes, 22

Schleiermacher, F., 86, 122, 127-28, 140, 281, 289

Secondat, Charles-Louis de, 20, 42

Sela-Sheffy, Rakefet, 198

Senior, Nancy, 296-97, 307

Serna, Justo, 97, 100

Shavit, Zohar, 181, 198

Sheffy, Rakefet, 79

Shen, Tkin, 248, 259 
Shuttleworth, Mark, 23, 43

Simeoni, Daniel, 79

Simmons, Jack, 327, 332

Simon, Sherry, 117, 118, 126, 128

Smith, Ernest Bramah, 243-44, 248-51, 253-57

Smith, Valerie, 261

Solano, Francisco de, 277, 289

Sommer, Doris, 238, 239, 240

Southey, Robert, 9, 309-28, 330-32

Spence, Lewis, 310, 332

Spiro, Melford E., 184, 198

Spivak, Gayatri, 52-54, 58

St. André, James, 8, 258, 261, 338

St. Jorre, John de, 193, 198

St-Pierre, Paul, 90, 97, 100, 113, 128

Staunton, Sir George Thomas: Chinese style of writing, 244, 247-48, 248, 253-54, 258-59, 338; Miscellaneous Notices Relating to China, 259; Narrative of the Chinese Embassy, 259, Penal Code, translation of, 338; Ta Tsing Leu Lee, 259; translation, free, 253-54

Stein, Peter, 147,162

Steiner, George, 6, 12, 87, 100, 139-40, 144

Steltzer, Ulli, 240

Stone, Lawrence, 97, 100

Struever, Nancy S., 205, 222

Suleiman, Susan R., 199

Swanton, Michael, 15, 43

Tanqueiro, Helena, 23, 43

Tayler, Anne, 240

Wallet of Kai Lung (Lung), 243-58

Thevet, André, 296-97, 302, 305, 307

Thireau, Jean-Louis, 146, 162

Timmermans, Felix, 72, 77, 78

Toledo School of Translators, 31-35, 108, 263, 270

Torah, 52, 181

Torres Del Rey, Jesús, 144

Toury, Gideon, 19-22, 43, 78, 84, 100, 199

translation: auto, 23,140; of banned books, 182, 187, 188, 189-93; censorship, 113, 180-95, 335; cultural filtering, 208; cultural grounding, needing, 232-38; fake, 21, 243-61; as foreignizing strategy, $86,234,301,317,327$; formulaic writing, 151, 154-56; free, 139, 149, 268, 270, 314, 316-23; heterogeneity of, $8,93,95,277$; ideological shifts, 179, 185, 203-204, 206, 217; interpretation, power-related, 47-48, 217, 230; interventionist approach, 156-58; language, deligitimizing, 65-69; literal, 145-48; mistakes, 30-35; over, 151 ; as performance, 18,258 ; power-related, $271_{i}$ practice, daily, 3, 15-19, 39; as propaganda tool, 35-40; pseudo, 19-22, 39, 191, 193, 243-44, 249-254; puritan, 179-95, 321-23; as rewriting, manipulative, 55, 281; self, 3, 22-25, 39; shift (semantic/syntactic), 210-16; subversive, 93, 180 186,188 translator: as artist, 227-30,317,319-21; as author 147; Baghdad school of, 32; as cultural agent, 85 ; as historical subject, 59-75; as intermediary, 164 ; invisible, $89,92,97,238$; as manipulator of text, $55,86,281,523-27$; obligations of, $69-74$; as operator, 87 ; as preserver of language, $231-35$; as sociopolitical agent, 206-209, 217, 226; Toledo School of, 31-35, 108, 263, 270

Trotsky, Leo, 164-65, 169, 175, 177

Tuttle, Edward F., 304, 307

Tymoczko, Maria, 85-86, 95, 100, 199

Tytler, Alexander Fraser, 140, 313, 332

Ullman, Sharon, 256, 261

Van Cauwelaert, August, 72, 78

Van Den Oever, Karel, 68, 78

Van Dijk, Teun A., 204, 222

Van Hoof, Henri, 16, 33-34, 43

Venuti, Lawrence: translation, foreignizing, 86, 301; translation theory, 88,89 ; The Translator's Invisibility, 100, 208, 222, 239, 240, 241, 307, 313, 332

"verbum de verbo", 26

Verdaguer, Isabel, 332

Verhavert, Cypriaan, 77, 78

Vermeer, Hans J., 12, 95, 100

Veyne, Paul: Comment on écrit l'bistoire, 128, 144; history, writing, 111, 117, 120, 132-33; periodization, 136, 143

Vieira, Else, 128

Von Busekist, Astrid, 79

Wakabayashi, Judy, 199

Weller, Georganne, 38-39

Weston, Stephen, 246-47, 259

Whale, Winifred Stephens, 163, 167-68, 175-77

Whatley, Janet, 9, 293-7, 300, 302-307

White, Hayden, 83, 94, 100, 144

Whyte, Christopher, 25, 43

Willie, A. MD., 196

Witte, Els, 79

Woodsworth, Judith: Teaching the History of Translation, 102, 109; Les traducteurs dans l'bistoire, 110, 331 , Translators through History, 88, 94, 98

WordSmith Tools, 208

Wullus-Rudiger, Armand, 64, 78

Xenophon, 14

York, Christine, 293-307, 339

Yûsuf, Ahmad ibn, 27

Zarandona, Juan Miguel, 9, 323, 332, 339

Zárate, Agustín de, 286, 288, 289, 290-91

Zohar, Zvi, 197 